
Digitized by the Internet Archive in 2007 with funding from Microsoft Corporation 



\section{A CHEECHAKO IN \\ ALASKA AND YUKON}




\section{OTHER WORKS B $Y$ CHARLOTTE CAMERON}

A WOMAN'S WINTER IN SOUTH AMERICA.

A WOMAN'S WINTER IN AFRICA ZENIA-A SPY IN TOGOLAND

A DURBAR BRIDE

A PASSION IN MOROCCO ETC., ETC. 



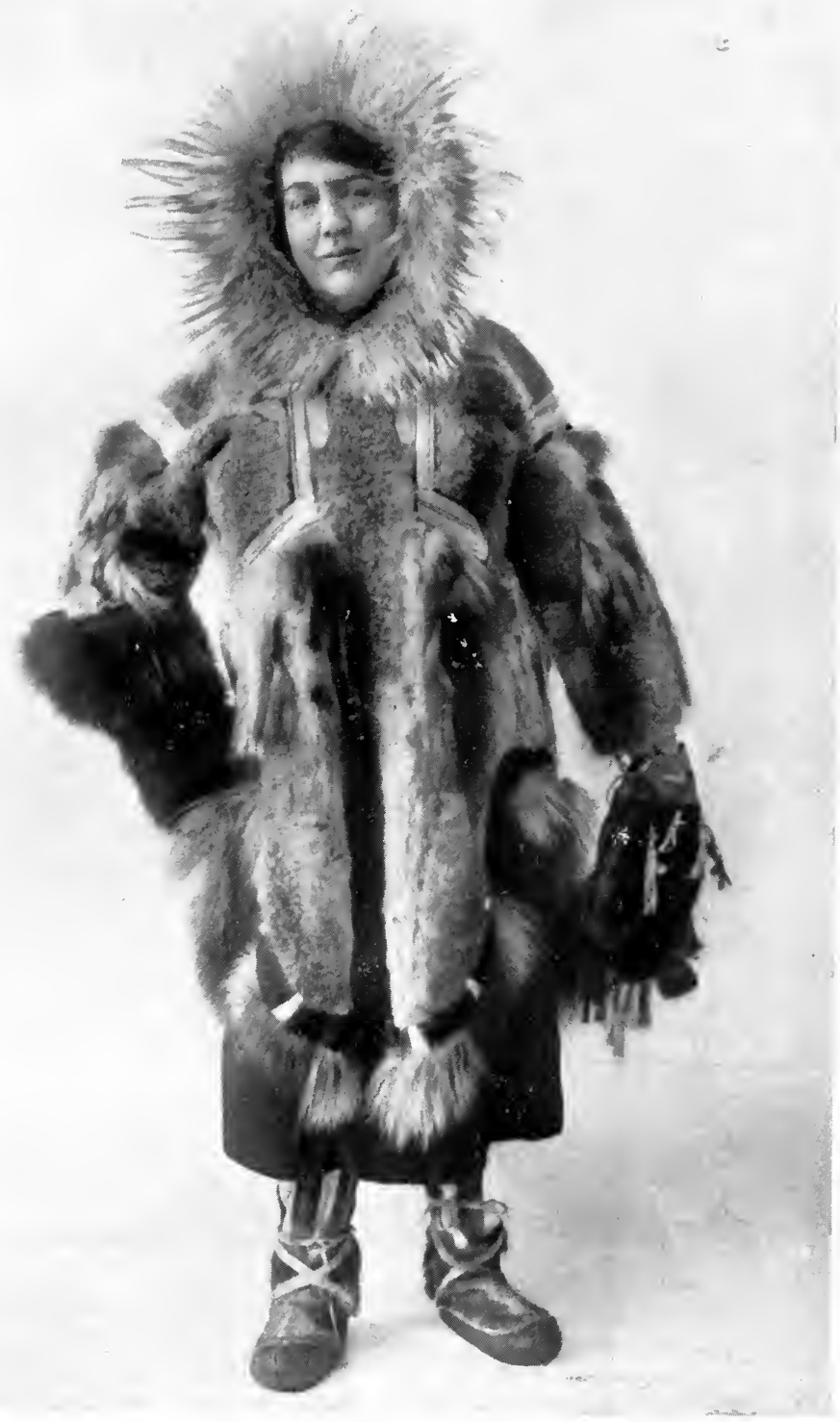

THE AUTHOR WEARING THE "PARKA" AND " MUKLUKS" OF THE ESKIMOS. 
tAm.

$31825 c$

\section{A CHEECHAKO IN}

\section{ALASKA AND YUKON}

BY

\section{CHARLOTTE C..AMERON \\ O.B.E., F.R.G.S.}

WITH A MAP AND THIRTY-SIX ILLUSTRATIONS

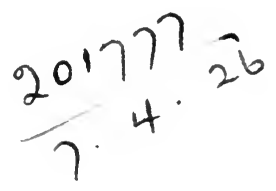

LONDON

FREDERICK A. STOKES COMPANY PUBLISHERS 
First meblished in 1920

(All rigiuls ieserved) 


\section{PREFACE}

As a child I was very partial to geography and all that it connoted, and I made up my mind that, God willing, I should one day wander across as large a portion of the globe as Fate would permit me. And Fate has been more than kind. In the rosy days of my youth, Nome, as a spot on the map, away off at the end of Alaska, possessed a peculiar fascination for me. It was about as far from England as one could get, and I wondered if, by any chance, Nome, this Mecca of mine, would ever find a place in my world itinerary. The Great War had finished. Since the first days of the conflict I had worked for our cause, sometimes washing dishes in military buffets, sometimes serving in one of the biggest canteens in London. Varied and intensely interesting were my experiences, whether serving or listening to the tales of homecoming warriors. Thrilling and blood-curdling were those simply told narratives. Followed a spell of Red Cross work -folding bandages, cutting cotton cloth, and the usual unvarying routine of the Service that occupied much of my time. Then on one occasion I was asked whether I was the Mrs. Cameron who had travelled all over Africa and toured the German colonies. This, of course, was a fact; I had written a book on the subject, as well as several other books of travel. It subsequently transpired that I was the only woman who could give accurate information of Togoland, the Cameroons, German South-West and German East Africa, as I had returned from Africa some few months before war broke out; and many things which seemed strange to me in those days were elucidated in the events which followed the 
declaration of war. Naturally, while touring Africa I had no idea that the Germans were so soon to unleash their armies to devastate Europe, although their officers frankly admitted that they wanted war immediately, even pointing out to me on their maps those of our Colonies which they would first take from us. Happily, the wish has proved to be father to the thought. After some lectures in England in aid of prisoners of war and Red Cross funds, I discerned that my mission lay in the direction of America. Here I lectured, and afforded press interviews on the war and its side issues, from New York to San Diego, California, almost to the Mexican border. It was the outstanding pleasure of my life to meet those charming audiences, and to explain to them to the best of my ability just how the Germans administeredor mal-administered-their colonies, and their bad treatment of the natives.

The war, thank God, had ended. There was no further sacrifice of splendid lives. And as I progressed through that beautiful State of California, Queen of the Pacific, with its glorious sunshine, carpets of wild-flowers, snow-clad mountains, and golden harvests of yellow oranges, yellow gold, and, in the north, yellow grain, I began to have thoughts of Alaska.

On the Pacific Coast one seems quite near, as Seattle is the principal port for embarkation to Alaska. One meets people who have lived there, who speak of the "Great Country," as the Indians used to call it. My mind was made up. Here, then, was an opportunity to realize that dream of my childhood and see Nome. But I am patriotic, and ardently desired to see the Yukon as well, so determined to wait until the snow and ice had melted in June. And thus it happened that in Golden California I abided until the season favoured my long-anticipated journey.

In this book I hope to travel interestingly with my readers along the route from Seattle viâ the Yukon-2,200 miles on 
the Yukon River, one of the four largest in the world-to Alaska, and back. It is useless, I fear, to hope that everyone could take a peep for themselves at the glorious scenery en route, and make the acquaintance of strange peoples-the Indians and Eskimos-their manner of life, and become more familiar with this vast Northland, a place where the hospitalities are boundless.

To the " sourdoughs" and " cheechakos," whose hearts are of gold, do I gratefully dedicate this volume.

CHARLOTTE CAMERON, O.B.E., F.R.G.S.

* A "cheechako" is a tenderfoot, one unused to the country. 



\section{CONTENTS}

CHAPTER

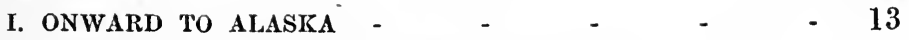

II. ALERT BAY, INDIAN TO'TEMS, KETCHIKAN - $\quad 20$

III. WRANGEL, PETERSBURG, AND TAKU GLACIER - - 31

IV. JUNEAU, CAPITAL OF ALASKA - - - $\quad$ - $\quad$ - 43

V. SKAGWAY, GATE OF THE YUKON AND HOME OF TIIE $\begin{array}{lllllll}\text { NORTH WINDS } & - & - & - & - & - & 52\end{array}$

VI. THE WHITE PASS AND CARCROSS - $\quad-\quad$ - 65

VII. ATLIN THE BEAUTIFUL - $\quad$ - $\quad$ - $\quad$ - $\quad$ - 79

VIII. MILES CANYON, WHITE HORSE, AND YUKON RIVER - 95

IX. HISTORICAL GLIMPSES OF THE YUKON TERRITORY - 106

X. DAWSON

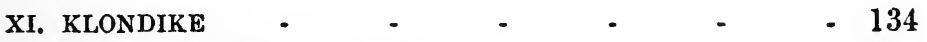

XII. FROM DAWSON TO TANANA - $\quad$ - $\quad$ - $\quad$ - 144

XIII. UP THE TANANA RIVER-HOT SPRINGS AND NENANA 156

XIV. FAIRBANKS, THE GOLDEN HEART OF ALASKA - - 165

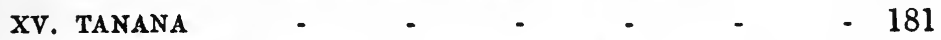

XVI. DOWN THE YUKON TO RUBY, NULATO, HOLY CROSS,

RUSSIAN MISSION, ANDREAFSKI, AND OLD HAMILTON 202

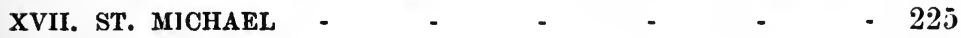

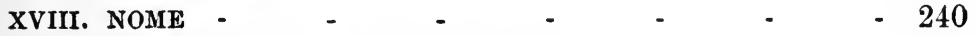

XIX. ESKIMOS: HABITS AND DANCES - - $\quad-\quad-254$

XX. A TRIP TO THE PIONEER MINING COMPANY - 262

XXI. SMEITING THE GOLD - $\quad$ - $\quad$ - $\quad$ - $\quad-267$

XXII. THE DOCiS OF NOME - $\quad$ - $\quad$ - $\quad$ - $\quad-270$

XXIII. DOG RACES AT NOME - $\quad$ - $\quad$ - $\quad$ - $\quad-275$

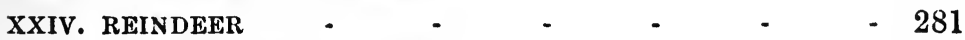

XXV. ANIMALS OF THE ARCTIC - - . $\quad . \quad-285$

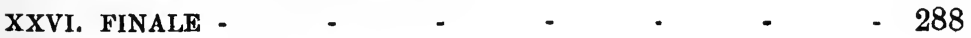

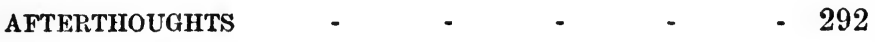





\section{LIST OF ILLUSTRATIONS}

THE AUTHOR WEARING THE "PARKA" AND

"MUKLUKS" OF THE ESKIMOS - - - - $\quad$ Frontispiece

GENEALOGICAL TOTEM OF SOUTH-EASTERN ALASKA to face page 22

INDIAN MEDICINEMAN OF THE CHILKAT TRIBE - " 22

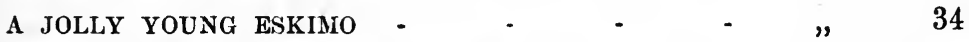

CHILKAT CHIEFS WEARING CEREMONIAL ROBES - "

PULLEN HOUSE GROUNDS IN WINTER - - - $\quad$ " 58

MRS. PULLEN'S ORIGINAL HOTEL, SKAGWAY - " " 58

SILVER FOX FARMING, CARCROSS, YUKON - - " " 70

A TRAPPER'S CABIN WITII SNOW-SHOTS AND PELTS " 70

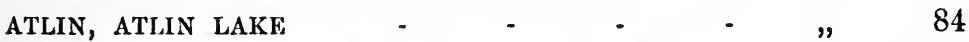

DAWSON WHARF : STEAMER AND "THE DOME" • " " 110

ROBERT SERVICE'S LOG-CABIN AT DAWSON : THE WRITER STANDING TO THE LEFT _ - - $\quad$ " 128

A MAIN STREeT, DAWSON : "THE DOME" IN THE

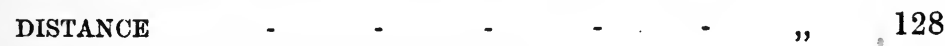

GOLD IN NATURAL STATE, KLONDIKE - - - " 138

PTARMIGAN IN WINTER DRESS : BROWN IN SUMMER,$" 146$

THE MIDNIGHT SUN : TAKEN JUNE 21ST IN THE

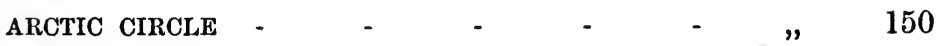

SALMON GOING BACK TO THEIR OLD HOME TO

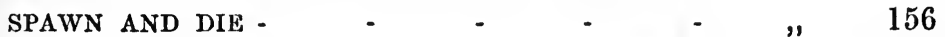

STRIPS OF SALMON BEING DRIED: YUKON RIVER - " 156

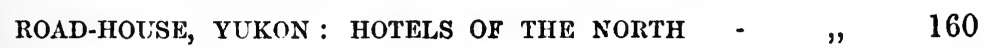

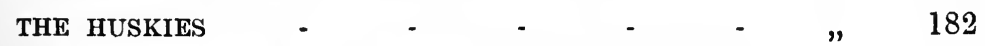

THE USUAL HOMESTEAD OF THE NORTHLAND MINER , 192

A CACHE FOR GUARDING FOOD : ESKIMO - $\quad$ - $\quad, \quad 202$ 
TYPICAL LANDING-PLACE AND WOOD PILE, ANDRE-

AFSKI, YUKON RIVER - $\quad$ - $\quad$ - $\quad$ - $\quad$ - to face page 202

ESKIMOS WITH REINDEER AND SLEDS: ARCTIC

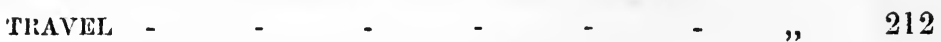

ESKIMO LIFE AT ST. MICHAEL, LOWFR YUKON - , ", 224

ESKIMOS AND KIAK BOAT - $\quad$ - $\quad$ - $\quad$ - $\quad$ " 224

RUSSIAN GREEK CIIURCH, ST. MICHAEL - - " 230

THE DESERTED PRIEST OF THE DESERTED CHURCH,

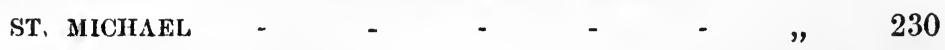

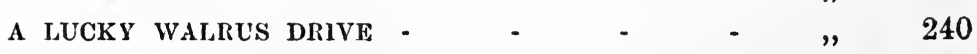

A Whale AT REST - $\quad \cdots \quad$ - $\quad$ - $\quad$ - $\quad$ " 240

ESKIMOS ABOUT TO DANCE THE WOLF DANCE - , 260

ONE MILLION DOLLARS IN GOLD BULLION : NOMF,

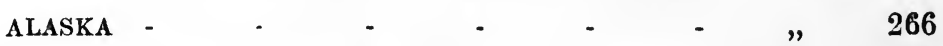

SEPPALA AND IIIS FAMOUS RACING DOG TEAM - - ", 278

DOG MAIL TEAM NEAR FAIRBANKS - - - $\quad$ " 278

CANADIAN ROCKIES, NEAR BANFF, C.P.R. - - ", 290

BA:FF HOTEL, C.P.R. $\quad$ - $\quad$ - $\quad$ - $\quad$ - $\quad$ " $\quad 290$ 
TYPICAL LANDING-PLACE AND

AFSKI, YUKON RIVER - $\quad$ - $\quad$ - $\quad$ - to face page 202

ESKIMOS WITH REINDEER AND SLEDS: ARCTIC

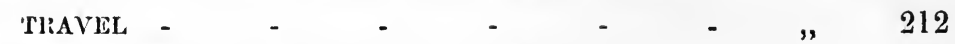

ESKIMO LIFE AT ST. MICHAEL, LOWFR YUKON - $\quad, \quad 224$

ESKIMOS AND KIAK BOAT - - - - - - " $\quad 224$

RUSSIAN GREEK CHURCH, ST. MICHAEL - - $\quad$ " 230

THE DESERTED PRIEST OF THE DESERTED CHURCH,

ST, MICHAEL -

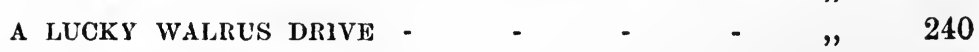

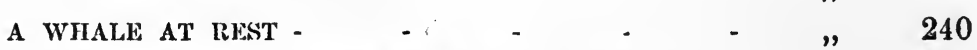

ESKIMOS ABOUT TO DANCE THE WOLF DANCE - $\quad, \quad 260$

ONE MILLION DOLLARS IN GOLD BULLION : NOMr,

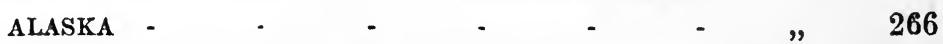

SEPPALA AND HIS FAMOUS RACING DOG TEAM - - ", 278

DOG MAIL TEAM NEAR FAIRBANKS - - - " 278

CANADIAN ROCKIGS, NEAR BANFF, C.P.R. - - $\quad$ " 290

BA:FF HOTEL, C.P.P. $\quad$ - $\quad$ - $\quad$ - $\quad$ - $\quad$ " 290 


\title{
A CHEECHAKO IN ALASKA AND YUKON
}

\author{
CHAPTER I \\ ONWARD TO ALASKA
}

ON Saturday, the 14th of June, at Vancouver, B.C., I boarded the C.C. s.s. Princess Alice, contemplating a journey of some thousands of miles into Alaska and the Yukon. There had been a deal of speculation as to whether the steamer would be allowed to sail or not, as the great Canadian strike was at its zenith, and labour wranglers threatened to prevent any movement of shipping. Although the prices of food, meat especially, were exorbitant, and the poorer people were suffering, the strikers preferred to allow 12,000 dollars' worth of frozen mutton to be returned to Australia rather than to unload it or permit volunteers to handle the cargo. Thus labour was defeating its own ends. It was, therefore, with no little apprehension that I packed my cabin necessaries and motored down to the C.P.R. wharf. After a minute scrutiny of tickets and passes, I was told I could go on board, and although the ship was due to sail at 9 a.m. she was not released from dock until 2.30 the next morning. The Princess Alice is a most comfortable boat of 3,000 tons. The saloons are homelike, the cabins all that is to be desired, and in the dining-room a feature is made of the small round tables, accommodating eight or ten persons, which is pleasant if you have your own party or if travelling alone, for the conversation becomes general. The food was excellent (I write as an experienced traveller); there was nothing to find fault with. 
One arose the next morning in dazzling sunshine, well content to leave strikes, riots, and such confusion behind, and look forward to the Land of Gold and Northern Lights.

How peaceful it was to lie back in a deck-chair and watch the mirror-like waters as the steamer glided and twisted past green spruce-fringed islands, with tumbling snowy cascades, deep tree-filled canyons, and trailing shores of countless blossoms! As the Inland Passage gradually unfolded, it disclosed an enchanting panorama of varied scenery. For people who are not good sailors a thousand-mile voyage on smooth, protected waters amidst this ever-changing grandeur must be a blessing indeed. With the exception of the short expanse of Queen Charlotte Sound, Millbank Sound, and Dixon's Entrance, which is negotiated in a few hours, there is practically very little open sea. There are some hundred people on board, bound for the Midnight Sun, which is at its best about the 21st of June. An excursion has been organized, the route chosen being through the White Pass to Dawson, and to Fort Yukon on the Arctic Circle, returning the same way. This delightful trip, perfectly planned, takes about twenty-one days, and costs something like 250 dollars. The excursionists were christened the "Midnight Sunners," and received a right royal welcome at Dawson and en route.

The dwellers in the Yukon and Alaska are just like one big family. They know each other thoroughly, and news is exchanged from " up there" and "down here." The people speak of " outside," meaning out of their country, they being bottled in, so to speak, by the snow and ice all the winter. Their experiences have the spice of unusualness, and you are indeed fortunate if you can prevail upon a sourdough to relate stories of vanished days, such as when the Beacon Gold led thousands to the North. Some emerged millionaires, others laid down in the frozen depths for ever. The women of the Northland are pioneers, and used to hard work and privations. Servants are practically unobtainable, the housework and care of the children thus devolving entirely upon the mother.

A Yukon young woman remarked to me, without the slightest attempt to refer to it as an unusual experience: "I 
had to cut firewood myself all last winter. My husband had died, and I was alone with the two children away out in the wilds. My hands don't look very well, because I split up five cords of wood." I looked at her in admiration and amazement. Then she related how an old Indian of seventy years or more had tried to shoot a bear, but failed, he only knocking out some of the female bear's teeth, which enraged the animal. The bear sprang upon the Indian, tore half his cheek away, and mauled him badly. The luckless native had struggled as far as her house, then fell fainting. She sent for a doctor, who, having dressed the wounds, said it was absolutely necessary that the Indian, who had never "tubbed" throughout his threescore years, should now have the bath of civilization. Being a Christian, the woman scrubbed the Indian, and for the first time in his life he knew what it felt like to be clean! So do these efficient, resourceful women fulfil their duty in these isolated outposts of the world.

Nothing could be more restful than to sit in a roomy cane, velvet-upholstered chair on deck, or, if the breeze proved to be too boisterous, within the glass-enclosed saloon, and watch one of the greatest of "living pictures" thrown on the screen of Mother Nature.

Every few moments the steamer swung to a different angle. The pilot must indeed be familiar with his work, for the slightest negligence would shove the Princess Alice on to shoals or half-concealed rocks. But it is not for the voyager to worry, only to drink deeply of the delights of this everchanging scene. Now the great mountains frown upon us, and a perfect lake is formed, full of mystic violet shadows. Apparently there is no outlet. Then a narrow channel leads us into broad waters, with flower-laden banks all aglow in the early spring sunshine. Thus we skirt the shores of British Columbia, proceeding through the glorious Inland Passage, thence to South-Eastern Alaska.

Most people imagine that in this part of the world one must necessarily suffer severely from the cold. This is a mistaken idea. Alaska has a most beautiful summer climate, 
something approaching our June weather, with a bite of the North at night.

The thermometer usually registers about 70 degrees, and farther up, in midsummer, sometimes as many as 90 degrees are recorded. This is often the case at White Horse and at Dawson. One wears the same clothing as in Englandcoats, skirts, and blouses, with a couple of simple dinner frocks. Throughout my long journey through the Yukon and Alaska I never wore a fur coat, although I was unfortunately burdened with one, because everyone had assured me of the intensity of the cold. One needs a warm woollen or, better still, a waterproof Burberry coat-I lived in mine, so to speak -and a fur or woollen rug one will find comfortable and well worth the bother of carrying. On no account take a lot of luggage, as in many cases you have to carry it yourself. There are no porters, and as there are few or no distinctions of class in this great Northland, it is not pleasant to ask your newfound friend to lug your superfluous belongings. To travel happily is to travel lightly. You feel abashed at seeing a man struggling with your encumbrances, whilst you nonchalantly look on. You arrange to give a final tip, and when you proffer it you are politely told, " No, thank you ; I am delighted to serve you." You regard the spokesman with amazement until someone will tell you, "Oh, that's Mr. So-and-So; he owns half the village and a number of mines outside." This often happened to me. Thus I advise all travellers in this part of the world to take with them only necessary equipment. Be sure and have at least one good strong pair of high leather boots, goloshes, as well as lighter footwear.

Every year a larger stream of tourists elects to follow this ever-enchanting route, bewildered by the innumerable emerald islands dotted upon azure waters. Towering snow mountains rise almost from the very deck of the ship, rocky canyons, narrow channels, and countless bays. Prodigal Nature is lavish in her gifts along this thousand miles of wondrous waterway, leaving an impress on the memory which can never be obliterated.

The class of people travelling consists of the sourdoughs 
(people who make their home in the North) and tourists who are attracted hence by a genuine love of adventure and travel. Comparatively speaking, Alaska and the Yukon are little known by the globe-trotter. The summer season is short, the country is vast, and one needs to arrive at the moment the ice has broken in order to form an adequate conception of its space and glories. By the end of September it begins to grow cold, and farther north at Nome the season is even shorter. Doubtless, now that the war is a thing of the past, travel in all lands will be resumed, and Alaska and the Yukon will generously repay adventurous ones who seek the beauties of those great lands.

It is in very truth a treasure-house of wealth, its gold resources practically untouched. Fish, fur, and other products are exported to the extent of millions of dollars every year.

The study of the primitive Eskimo and Indian peoples is in itself a fount of inexhaustible interest, while the hospitality and kind-heartedness of these Northerners know no bounds. They do not approve of "fake" or " side" ; but if you come to them as one human being to another, they grasp your hand in real warm friendship. They adopt you, and will share their last crust if necessary. You are 100 per cent. good in their estimation, and it behoves you not to show any alloy in your nature.

Alaska was unknown to the white man till 1741, when it was explored by two Russian officers, Captains Vitus Bering (some spell it Behring) and Chirikov. Thirty-three years later some Spaniards visited its shores, coming up from the Pacific, and in 1778 Captain Cook had a look in, taking some surveys of the coast. But the first important survey was made by Captain Vancouver in 1793-94. The Russians took possession in 1799, and the chief resident director was Alexander Baranov, who founded Sitka, the capital, in 1804. The reign of this chartered company ended in 1861, when Prince Maksutor became Imperial Governor, and it was six years later, 1867, the same year in which Canada was confederated into one Dominion, that the United States purchased Alaska, which comprises one-sixth of the area of all the possessions 
of the U.S. in North America. The meaning of Alaska is " Great Country," derived from the Eskimo word Al-i-ak-sa, and the coast of Alaska alone covers over 26,000 miles. It was Peter the Great who sent Vitus Bering to explore this coast. Some claim that Bering was a Russian, others that he was a Dane. Very few of the world's inhabitants realize the extent and economic greatness of Alaska, its vast resources, and huge potential wealth- "Our last frontier," or " Our big out-of-doors," as the Americans phrase it. When William H. Seward, Governor, United States Senator, and Secretary of State during Lincoln's and Johnson's administrations, purchased from Russia in 1867 this territory of over 600 square miles for the sum of $7,200,000$ dollars, everyone laughed, referring to the transaction as " Seward's Folly " or " Seward's Icebox." But the far-sighted Seward knew what he was about. Since 1867 Alaska has produced minerals to the value of $419,218,794$ dollars. The fish products have yielded $347,551,733$ dollars. Furs and skins realized 79,192,870 dollars, and miscellaneous wood, curios, etc., 1,756,011 dollars, making a grand total of $847,719,408$ dollars-not a bad bargain for a territory that changed hands at 2 cents an acre!

And yet the surface of Alaska has scarcely been scratched; its destiny is surely that of one of the richest lands of the future. Thus, America has reason to be grateful to Governor Seward for his foresight and wisdom in securing territory whose area is equal to twelve times that of the State of New York, nine times that of Washington, 470 times that of Rhode Island, and is as large as France, Spain, and Germany combined. In this great Northland of beauty and promise not more than 2 per cent. of its area is covered with perpetual snow and ice. All kinds of wild-flowers bloom naturally right up to the Arctic border, and through the summer season there is practically no night, so flowers and vegetables benefit markedly from the twenty-four hours of continuous daylight. One therefore need not be surprised at seeing dahlias 10 to 12 inches in diameter, sweet peas 12 feet high, and all other flowers no less generously proportioned. 
The present civilization of Alaska will be a source of wonder to the traveller. In all the towns electric light, telephones, automobiles, cinemas, wireless telegraph installar tions, and good shops, with every requirement of modern life, are to be found. Every town of any size has its churches, schools, hospitals, libraries, clubs. It is astonishing the progress that has been made during the last ten years. Although Nome is frozen solid for about eight months of the year, and cut off from the world by way of the water, yet the wireless flashes its news over the thousands of miles of snow and ice. Nome, the farthest big town of Alaska, is thus kept in touch with current events, and furthermore, twice a week the dog-mail team arrives with its delivery of mail, having had a run of 1,500 miles to fetch it.

It may not be in our time, but in the future Alaska will give birth to great cities along its beautiful rivers and enormous coast-line. In the shelter of its deep valleys agriculture will become a staple industry able to feed vast populations, who will call Alaska "Home." At the present moment farming has advanced enormously around Fairbanks, the Tanana Valley, and other places. It has been proved by the Government farms at Sitka, Rampart, and Fairbanks that farming can be made a success even in this cold country. All that is needed is Uncle Sam's willingness to delve into his voluminous pockets and afford Alaska transport facilities. Tap the rich virgin coal-mines, give the people the railways they need! But the U.S. Government are so busy at Washington. Party politics and sundry other things occupy so much of Government brains and Government time that Uncle Sam has been apt to forget his great treasure-house in the North. But one day-and let us hope soon-as the congestion of the world's surface becomes more acute, America will remember, and Alaska will then come into its own.

Isolated in the North, clad in its wondrous purples, blues, and greys, Alaska is now a Cinderella in the opulent family circle of Uncle Sam. 


\section{CHAPTER II}

ALERT BAY, INDIAN TOTEMS, KETCHIKAN

IN the cool of an early morning we paused at Alert Bay, at the north of Vancouver Island, famous for its salmon canneries and totem-poles. All the buildings are constructed of wood, and very rickety they look! Saw-mills and floating logs testify to the systematic slaughter of beautiful pine and spruce. Two islands stand out like sentinels of the deep. Obviously there has been a recent gale, as many trees are uprooted, while others are snapped in twain like broken matches. Soft white clouds rest upon the tall dark mountains, resembling wreaths of snow, and, reflected in the calm waters, make a picture truly ethereal. Groups of small houses nestle close to the water's edge. Alongside, awaiting their turn to the cannery, are tugs laden with glittering treasure of silver fish, these soon to be packed and despatched all over the world. I go ashore and wander up the principal street, or road, to study the marvellously weird totem-poles, encountering many Indians, a large number of whom work in the cannery. To the Indians these totems are objects of greatest reverence, denoting, as they do, the coat of arms or tombstone of ancient families long since departed. They have so awesome a respect for these inanimate emblems, that rarely will you induce an Indian to discuss them at all. However, at Alert Bay are many of these poles, and the traveller can roam about and study them leisurely. To one who has never seen an Indian totem-pole it is a thing to be remembered. Carved out of wood and gaily painted in every conceivable colour, they range from 3 to 40 feet in height. Imagine a carved monument, we will say, 20 feet high. The "Raven" totem is a huge bird's head with tremendous beak, crowned with a tall stove-pipe hat. His eyes are red, and his beak cobalt blue; 
whilst below his knees, hunched up like a "Billikins," is a queerly shaped man-like figure. At his sides enveloping wings apparently shield him. Beneath him is a box enriched with peculiar carvings; then comes an animal's head with beak protruding at least 2 feet. Below another man-god, or whatever they call it, he also invested with wings. Attached to the former is a fearsome-looking black hawk's head with enormous green eyes, many wrinkles of vermilion, and a hooked nose. The body of the hawk has a number of outlandish designs painted on it in a multiplicity of colours. The figure at the base supporting this queer collection is an uncouth man seated, with terrifying eyes, nose, and wide mouth, a sort of spear held fearsomely in his grasp. Mentally place every thinkable colour on this column or totem, and you have the " Raven," one of the most conspicuous of the monuments you are likely to encounter.

Remember that every one of these figures has a definite meaning, just as have the hieroglyphics of Egypt. They relate the history of the past, the genealogy of important families, and are sacred to the Indians. It was certainly interesting wandering around these, to us, grotesque emblems of former greatness.

Sometimes a totem would disclose a beaver at the summit, a whale, eagle, frog, or bear, according to the traditions of the families represented. The word "totem" was first heard of in English records in a book written in 1791 by J. Long, who was an interpreter between the whites and the Red Indians of North America. The native word for totem is ko-te-a, which in their jargon means image, or likeness. In their hoary legends the natives believe that the origin of man came viâ the animal kingdom; hence the zoological element in totems as a whole. I was much surprised to notice that the representations of the raven were by far the most numerous of the totems. Being somewhat of an Egyptologist, and having passed several winters in the Land of the Pharaohs, in many respects the raven seems to me to bear a resemblance to the great Horus of Egypt, the hawkheaded god, and, in Peru, the gods of the Incas. Their mono- 
liths and carvings also recall a similarity to those of Egypt, as do these strange outlandish totems of the Indians.

Like the Egyptians and the Incas, these Indian survivors do not build emblems to perpetuate their contemporary history. The poles should therefore be preserved for future historians, and not allowed gradually to rot, as they are now doing. They were not erected to be worshipped in the sense of a deity or god, but were highly reverenced as a standing monument to different tribes or clans, and represented to the Indians what a coat of arms would to an English family.

For instance, an Indian on the trail, on reaching a hut or tent at which a totem was standing, would, if that totem (or family tree, as one might describe it) was the same tribal emblem as his own, enter and make himself thoroughly at home, expecting every hospitality, as if by right. If, on the contrary, the totem bore none of the animals, birds, or images of his family emblem, he would never dream of intruding, no matter how weary or hungry he might be. Now, the Indians, fast dying out, are most reticent about their private affairs. As they leave no books to chronicle the why and wherefore of the totems, there is a great deal of conjecture and mystery about them. In some instances they stand singly before a house or hut, and in others there will be dozens clustered together. One might suppose them to mark a burial-place, the totem-poles being used as tombstones. Like the Egyptian, the Indian spent much of his time in contemplation of the after-life in the happy hunting-ground. $\mathrm{He}$ paid full attention to the rites for the dead, and, viâ the medicine-man, appeased the spirits. It seemed strange to contemplate that these totems, recording the genealogy of the family, should always be crowned by the totem of the mother's family. Next below would be the husband's totem, and so on to the base. Anyone could trace all the family relations in this way.

In South-Eastern Alaska the Indians were divided into two great clans. The eagle was known as the man's totem, and the crow represented the woman's. The sub-totems, or 


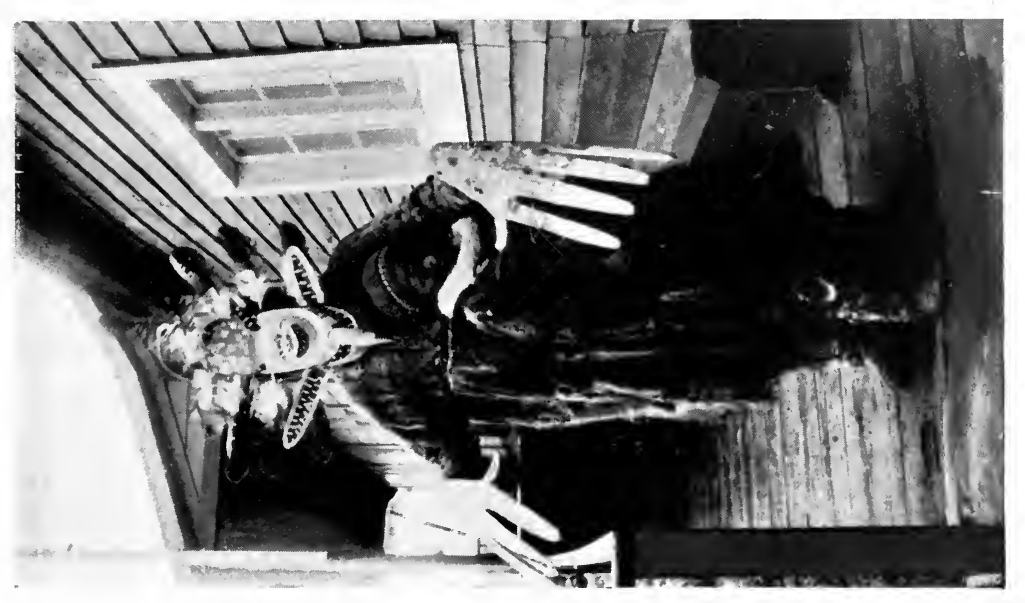

告

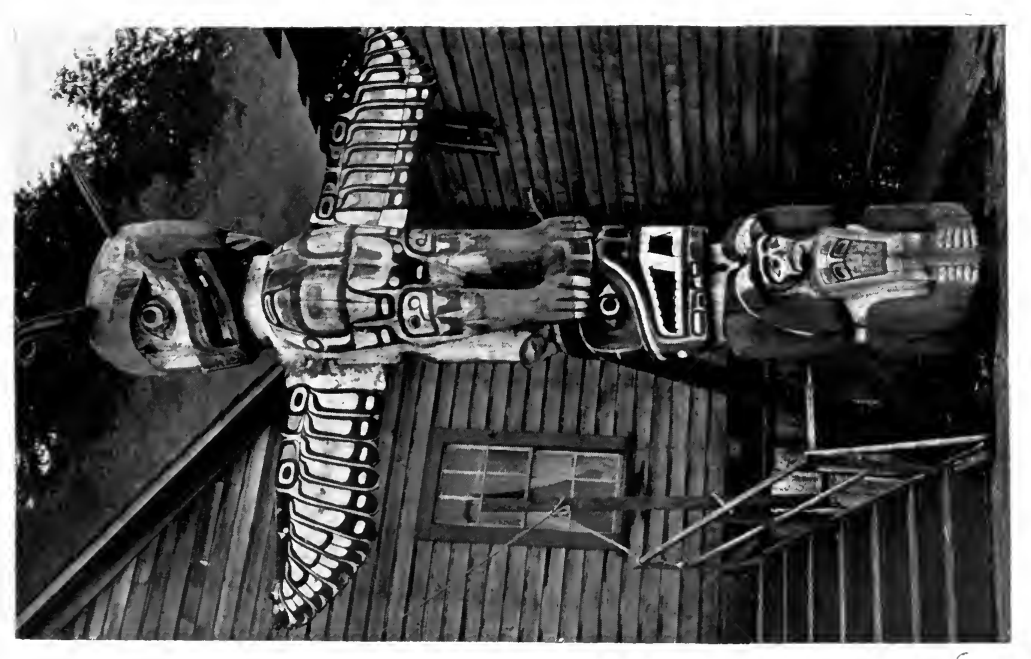

1 

satellites, of the eagle were the bear, wolf, whale, and shark; and of the crow, the beaver, frog, salmon, and seal. One of the legends of the raven is that at the time of the flood the raven, taking his mother in his arms, flew up to the heavens, stuck his bill in the clouds, and remained there until it was safe to return to earth. For this reason, they say, the raven's beak is always portrayed as being bent. Another story is that the raven long ago disguised himself as a fish, and fell to a fisherman, who pulled off his beak. Some time after he discovered the whereabouts of the missing beak, and by a ruse recovered it, but in his hurry he stuck it on wrong way up, and never put it right again!

Another ancient myth has it that in the beginning of the world all was chaos. The creator, the great raven, lived in seclusion, and, miser-like, kept everything for himself, including the sun, moon, stars, and fresh water. The legend goes that the moon, sun, and stars were kept in three bags. A child came to earth, and was so wonderful that he found favour in the creator's eyes, and used to go to him and play. The little one managed to possess the bag containing the stars. He threw them up into the sky, and they stayed there; next he tossed up the moon, that also rested, yet still he was unsatisfied. Then he cried to the creator for the sun. This, too, he hurled into the depths of the sky, and glorious light resulted. The mortals, however, were frightened by the radiant light. Some jumped into the sea and became fishes, others fled to the mountains and lived as wild animals and birds. Thus, says the legend, the raven was the creator of man!

I, who had travelled in nearly every land, had never seen anything quite like these totems, nor had I heard anything so fascinating as their legends. But the siren of the modern Princess Alice called us to forsake the lore of the totems and proceed on our voyage.

Naturally all the passengers, especially the Midnight Sunners, could talk of nothing but totems. Many had bought small models to take to their friends in the homeland. The sourdoughs added their knowledge about poles, and told 
us we had not even begun to see totems as yet. Let us wait until we arrived at Wrangel, Ketchikan, and Sitka! As we swung out of Alert Bay, we agreed that we had rashly neglected to visit the silver-fish cannery-the weird totems had taken up all our time. . . .

We drift past range after range of mountains and densely wooded islands, promontories shielding white lighthouses, and waterfalls tinkling music in their downward career. Now the bay widens, and we pass Bella Bella. Then on to the open waters of Queen Charlotte Sound. The surf of the Pacific rolls in upon us, but only for a short time after passing Dixon's Entrance, the international boundary-line; then again we are sheltered by lovely islands, to which we pass so close we can almost touch the trees. Some moments we find ourselves in fjords like Norway, fenced in by snowy peaks, reflected grandly in the blue, still waters. The sunset is too wonderful to believe or attempt to describe. Everything is tinged with purest gold, except the snow on the mountains, which is blush-rose in colour. Then the gradual fading of the picture, until all the world seems bound in mauve and pale rose. Prince Rupert would have been the next port of call, but unfortunately our boat pushes directly on to Ketchilian, where we have deep waters on one side and mountains on the other.

Ketchikan is our first Alaskan stopping-place, and very attractive it looks from the steamer as we draw up alongside the wharf. The town is in its youth, but has accomplished much in its sixteen years' career. It is Norwegian in appearance, having been built at the foot of a green mountain which is covered with trees right to the summit. Natural forests surround it on all sides, and it would seem that in building the place they had simply cleared only sufficient of the woodland to wedge their town in it! The houses appear from the distance as if they were built one on top of the other, or on any projecting rock. They are of wood-or "frame" they call them-as are also the planked irregular streets. At a glance the fact is revealed that this is a "live town," as the Americans phrase it. Steamers, tugs, fishing-boats, and canoes 
rush about the calm waters full of bustle and enterprise; the steamers seem to snort at the landing-places for attention!

The pioneer of Ketchikan was Mr. M. E. Martin, who was responsible for the building of this quaintly named town. In $1885 \mathrm{Mr}$. Martin came to Alaska in search of a site, near to the fishing-grounds, for a cannery. He wisely considered that Ketchikan would best suit his purpose. Gradually Ketchikan became the centre of the greatest fishing industry in Alaska, not only as regards salmon, but halibut and other fish.

The only rivals in the trade are Petersburg and Wrangel. Subsequently Mr. Martin became the first Mayor of Ketchikan, and all his prophecies regarding its development have so far materialized. Ketchikan has now some half-dozen salmon canneries and several enormous cold-storage plants, and is the distributing centre for more than fifty canneries in the neighbourhood.

It was most exciting to go ashore and explore my first Alaskan town, the beginning of a long trail which embraced most of the habitable places in this "Great Country." A party of us wandered along the principal front street, our eyes glued to the shop windows, which we found most interesting. There are some very good stores wherein one's practical wants may easily be gratified: jewellery shops displaying nuggets of gold, a concrete department store with plate-glass windows, excellent fruit, with enormous berries grown locally. Ketchikan is likewise famous for its salmon berries, which are pale pink in colour, raspberries, and wild blackberries. 'We discovered an up-to-date photographer's, a great display of furs, in which fox, red and silver, predominated, and beautiful mink. But the prices were by no means moderate-in fact, one could purchase just as well in London! The furs, it seems, have to be sent to the big cities to be dressed and lined, and transport is an expensive item. Skins purchased direct from the trapper himself, if you can arrange this, very frequently turn out to be bargains. Ketchikan has two cinemas, several hotels-the " Revilla" is a three-storied frame building and quite comfortable-numerous restaurants, amongst which is the oddly named " Poodle Dog." Its array 
of public buildings-churches, schools, public library, Board of Trade-and residences leaves nothing to be desired.

We were continually climbing up white-railed steps or stairs leading to pretty houses, mostly painted white, with piazzas (as the Americans say) or verandahs. Superb views are obtained of the waters below, of the dark evergreen forests surrounded by glistening silver-decked mountains. The cool fresh air from the snowy heights imparts a crispness to the atmosphere which, to me, recalled Scotland. In the residential district everyone seemed proud to possess a garden, and some very notable ones we passed. We were told that gardening was difficult, because the heavy rainfall tends to wash the soil down into the narrows, and the people frequently are obliged to renew it. We met many Indians on the way. They have a pronounced Mongolian cast of feature; one would suppose they had mixed with the Japanese.

On turning a corner we came upon a terrible fight between Chinese. It was quite a sanguinary brawl, but in a few minutes some policemen arrived, and participants and crowd disappeared.

One of the sights of Ketchikan is the snowy, rushing stream, which gushes in cascades, and whirls past banks of emerald bushes, flowering shrubs, and wild-flowers, straight through the town. It is a salmon stream, its sparkling waters boiling and foaming over moss-grown boulders. Here you can see the great silvery fish leaping through its crystal depths, jumping and swimming up-stream to spawn in their original waters. It is the peculiar nature of the salmon to return home to perpetuate their species, for after spawning both the male and the female salmon die. Nevertheless, it is a curiously thrilling sight to watch them fighting and leaping to their home waters. Later in the summer the salmon are so numerous you can actually pull them ashore with your hands, so local folk informed us.

We noticed fine porcelain drinking-fountains placed at various street corners, and sampled this excellent pure water. Bubbling up incessantly, it comes down from the mountains in pipes, and the surplus is used to supply power for the 
town's electric light. Ketchikan is rich in totem lore, and upon returning from our inspection of everything pertaining to the town we stopped to photograph Chief Johnson's totem and residence. The one-story house was small, and painted pink. It had a window on either side of the door, and over these was painted in weird colours a huge whale with large open jaws. This totem design covered the entire top of the house. Beside it rose a very tall totem surmounted by Ka-juk, a fabled bird who looks like an eagle. According to legend, he has the curious habit of occasionally hurling down rocks; those who find them are supposed to become very wealthy. Unfortunately, it didn't happen to be his throwing day when $I$ saw him! This totem is unique, because of the manner in which the bird is placed on a very high pole. No other decoration occurs until halfway down, when two queer images, supposed to be servants of the raven and fire-eaters, are hewn out of the wood. Below them, again, is another figure, the fog woman, a salmon in her hands.

One of the interesting totems has the supposed face of Captain Cook. It seems that the founder of this Indian clan was the first to see Captain Cook, and the tribe henceforth adopted the name Cook as one of their own. On Cat Island, they told us, were groups of interesting totems, amongst which was the grizzly bear, the raven, and Kit, the whalekiller. Unfortunately, our time did not permit of a visit. Chief Kyan's totem, which is near St. Tohn's Church, is a large, gorgeous structure, truly Oriental in colouring. The pole is surmounted by a crane. Below is Kyan, and in rotation below, the thunder bird and the grizzly bear. In totem language it reads: "I am a member of the crane family, and member of the thunder bird and bear." These are wonderful relics of past Indian greatness, and, indeed, it is quite worth a trip to South-Eastern Alaska just to see them. But, as I recently suggested, at the present rate of decay, unless the Government take better care of them, the next generation will never behold these emblematic images.

After lunch I was invited to go over a large canning factory, where cleanliness, hygiene, and ingenuity are the dominant notes. 
Never be afraid to partake of Alaskan salmon if the tin is opened before you. It is quite above suspicion. The salmon are delivered in boats tightly packed with the shimmering spoils, mostly alive and just fresh from the water. They are passed through elevator shoots into the cannery and fed individually into a machine, which slits them open, draws out the intestines, and chops off heads, tails, and fins. Then they are slid into an automatic washer, and eventually into another machine, which skins them and removes their backbone. The same machine fills this clean, raw salmon meat into tins, and as they pass along Indian girls fill the cans by hand on an endless belt. The can then travels until a tin cap is put on and soldered tight, a small needle-hole being left in the centre of the cap. They are then placed into racks holding, perhaps, over a hundred cans, and when full are transferred to a low truck, and the next rack put on top of it. This process is repeated until the racks number fifteen.

The truck is now pushed into the steaming room, each cubicle just big enough to hold a single truck. Every door is sealed tight, and the steam turned on. In this manner the fish is subjected to steam heat (without any handling) until thoroughly tender. When the process of cooking is completed, the cans again move on automatically into another machine, which solders up the little holes in the cap. Another machine labels the cans, and finally they are packed into boxes each holding two dozen cans. Thus the salmon are made ready for the market, and despatched all over the globe. In the cold-storage department the fish are cleaned and washed, then put into the freezing rooms and frozen solid. These are stored in warehouses, then packed in large wooden boxes, and shipped in their frozen state wherever required. As long as they remain frozen they will keep for an indefinite period, and when cooked there is no means of showing that they had not just been taken from the water. In proof of this, Major Hugh Green (who is interested in the Canadian fishing industry, and who was responsible for the provision of fish for our soldiers during the War) gave a fish banquet to the Press and important authorities. The dinner, of ten 
courses, was held at the Piccadilly Hotel, London. The menu opened with cocktails, and, like a petal of a white rose, one flake of white fish floated in the glass. The soup was of fish, and other fish courses, delicious in every respect-among them the delicate white fish of the Canadian Lakes-were served in rotation. The diners found it hard to believe, at the end of the repast, that all the fish had been frozen, and that the delicate white fish of the Lakes had been frozen stiff for eighteen months! Many articles appeared in the London Press in praise of this process of preserving fish, and I recall the incident because of its evident appropriateness. The canneries and cold storage were certainly a revelation to me, and, realizing the cleanliness of the canning and the handling of fish, as the Scots say, "I'll ne'er hae me doots again."

Besides fishery, Ketchikan, with its 2,000 and more population, is interested in mining-gold, copper, silver, lead, and marble being found near-by. But capital is needed if this phase of activity is to develop. On Prince of Wales Island the mines are more active than formerly, and encouraging results are expected. Also, timber is an important industry, and paper mills could be successfully run, as there are endless forests of spruce and all the water-power necessary. It is reported that the Government have taken an interest in the pulp manufacture, and are raising quantities of spruce for the making of aeroplanes and propellers. Besides spruce, hemlock, western red cedar, yellow cypress, fir and pine, decorate the dotted islands and mountain-sides. The climate of Ketchikan is mild; there is very little snowfall except in the mountains, and it rains considerably. The highest recorded summer temperature is $94^{\circ} \mathrm{F}$., and the lowest recorded is $27^{\circ} \mathrm{F}$. Visitors to Ketchikan should not neglect to see Prince of Wales Island across the way, and roam about old Kassan with its groves of ancient totem-poles, even more curious than others already described. 'Kassan was the great stronghold of the Hydahs, one of the most remarkable and talented of the Indian clans. A week certainly should be spent at Ketchikan, in order to make the most of the various points of interest. It is my good-fortune to have as friends Senator and 
Mrs. Heckman, real pioneers of Ketchikan. To them I am indebted for many Alaskan stories. There is no more popular man in Alaska than " Bob" Heckman, as his numerous wellwishers like to call him, and it was my pleasure to travel over many long trails with the Senator and his wife. They are greatly beloved in this part of the country.

I have already described to my readers how much the Indians respect the dead, around whom most of their thoughts are centred. Mrs. Heckman had been very kind to the natives, especially those who worked in her husband's canneries. The Indians appreciate and are very fond of her, and this is their manner of showing it: They say, "Oh yes, Mrs. Heckman very good, very kind lady; all we Indians go to her funeral."

The Indians can pay no greater compliment! 


\section{CHAPTER III}

\section{WRANGEL, PETERSBURG, AND TAKU GLACIER}

IT was raining heavily when I left Ketchikan. One regretted it, as Wrangel Narrows is regarded as a Paradise of scenic loveliness. At present one can just make out the white buoys as the steamer glides past very slowly. Promontories and small capes are dimly defined in the mist. Gulls shriek, flutter madly, and disappear. After everyone has bemoaned the atrocious weather, the great golden orb of the sun breaks through, the mists are parted like curtains, iridescent rainbows sparkle on the waters, throwing splashes of colour on the thickly wooded mountains. Nature decides to dry her tears, and glows benignantly in the sunshine. We find ourselves passing through Clarence Straits, and within sight of Fort Wrangel, one of the oldest settlements of South-Eastern Alaska, and occupying a unique position on Wrangel Island, near the mouth of the Stikine River. Wrangel has about 1,000 inhabitants, and was founded by Baron Wrangel, Russian Governor of Alaska, in 1834. As far back as history records, the Stikine Indians had a stronghold here. It was the scene of great "pow-wows," as well as potlatches and other curious ceremonies. Wrangel also is famous for its totems, and it is said that the first totems known were planted at this spot. The present Indian village lies to the south of Wrangel, and not far from the two piers which push out into the Narrows. Wrangel is more level and spacious than Ketchikan; all the houses and streets are of wood. There is the Wrangel Hotel, a good-looking public school, which supports four teachers, and a Government Indian school. Something like 800 Indians reside in the district, many of them employed in the canneries and cold-storage plant. Another industry is the sawmills, box factory, and shingle mills. 
Wrangel has one private hospital, and several churchesincluding the Presbyterian, Episcopal, Roman Catholic-and a branch of the Salvation Army.

Upon going ashore I found a good curio-shop, Berthelsen and Pruell, at Ketchikan; and this one, as others, at Wrangel, are like magnets for extracting money from one's purse, for the simple reason that Alaskan curios are distinct from those to be found in any other part of the world. For instance, there are the Attu baskets made by the Attu Indians, who are fast dying off. These are fashioned of spruce and cedar root, some of them plaited under water, that they may be more pliable. A really good basket is a work of art, and it is almost incredible that the plaits can be so minutely and delicately woven, as fine indeed as a coarse linen, and much more carefully plaited than the celebrated Panama hats. These baskets are usually small in size, and dyed by vegetable colours known only to the Indians. In price the best Attu baskets fetch from 25 dollars to 200 dollars; and it is clear that before long one will not be able to procure them at any price, as the modern Indian girl will not bother to make baskets that call for patient, exquisite handiwork. She much prefers working in the canneries, and buying cotton gowns and white boots. Here you also find a selection of old ivory, consisting of carved napkin rings, totem-poles in miniature, gaily coloured, cribbage-boards, and cigarette-holders. But if going to the Eskimos country, one had better wait and purchase ivories there. Soon we leave the totem country, and these souvenirs are not procurable elsewhere.

The Indians fashion jewellery and souvenir spoons out of silver, with weird designs, many of them copied from the totems. Wide bracelets of silver are especially in vogue among them. Wood and slate totems can be acquired that are the exact reproduction of the originals, as well as little books describing the various figures. Here are old war knives that were used for despatching the slaves, after the death of great chiefs, implements that also played a part in the riotous potlatch feasts, copper weapons and kettles which have been hammered out of the rich deposits of the ore in the mountains, 
and said to be in use since the days of the first Russian settlers.

In these Indian curio-shops one becomes familiar with old fossilized ivory. It is in many instances quite brown in colour-in fact, its varied ranges suggest a symphony of browns, from pale cream to almost black. This ivory is not local, but comes from a distance-the shores of the Arctic Ocean and the Bering Sea-and is not at all plentiful. Occasionally the Eskimos will find a deposit of this precious ivory, and will bring it to the trader and exchange it for food, "kow-kow," and other requirements. This fossil ivory is of the mammoth, mastodon, and walrus, and has presumably, if we are to believe the scientists, been buried in the earth some hundreds of thousands of years, where it has lain fossilizing, the deep colouring induced by the various minerals in the earth. When polished, and flanked, or framed, by small pure gold nuggets, which is the recognized fashion of mounting, the effect is handsome and extraordinary. Rings, cuff-buttons, crosses, brooches, and necklaces, ranging in cost from two pounds sterling upward, make unusual souvenirs for our friends at home, as one can only purchase them in Alaska. Another outstanding curio is the Chilkat blanket. These also will soon be unobtainable. They are indeed most picturesque, and assume the form of a very thick woven circular garment, usually a wonderful shado of imperial yellow, worked with pale-blue symbolic designs, denoting clan traditions, and crossed by black squares symbolizing eyes, and various emblems. These robes, or royal cloaks, are edged by a long thick fringe, a foot and more in length, of mountain sheep wool. The Indians wear them slung across their shoulders, and keep them in place with a special rope fashioned out of the finest birch bark. Even in these days the Chilkat blankets are difficult to secure, and are unobtainable at less than 100 dollars for a full-sized specimen. Soon they will only be seen in museums, and then but rarely. Woman-like, I succumbed to temptation and bought one. I am indebted to the Ryus Drug Co., of Ketchikan, and to Mrs. Kirmse, of Skagway, for the sub- 
joined information regarding the history and making of the royal chieftain's Chilkat blankets. They were used on all ceremonial occasions, were frequently worn at a dance, the chieftain entering and dancing backward in order to show them to advantage. After the dance they became the property of the clan. As the Chilkat tribe, as in the case of the other Indians, believe that the dead should always have the best of everything, and that the spirits must be propitiated, the Chilkat blanket was used at funeral ceremonies, to be hung up alongside the remains. They believed that the friends of the dead who returned to take their departing relative would be made happy by looking at its bright colours and striking emblems. The design on the blanket in the picture represents a whale with large eyes. In the centre is a female bear, with two cubs. There are many other types, expressing other sentiments and associations. One of the legends of the Chilkats is that, before the Flood, men were like animals, and could take off their skins like a blanket! A chief's daughter, it is said, whilst out gathering wild celery, slipped in the footprints of a black bear. She became very angry, abused the bear family, and finally lost her way. At dusk she heard a footfall. A beautiful young man approached her, and, making very violent love to her, asked her to marry him. She consented, and went to his home, and there made the tragic discovery that her lover was a grizzly bear! Terrified, she made her escape. Running to the sea, she saw a fisherman in a canoe, and begged him to save her. Before taking her on board the fisherman made her promise to become his wife. This she readily did, and the fisherman turned out to be the Good Spirit of the Sea, called " Konakadet." Now, when they both descended to the spirits' house under the ocean, he told his bride that he had formerly married a lynx, but that his wife was so cruel and badtempered that he meant to kill her. He put the new wife in a cave, and told her not to be frightened at whatever she saw. She was obedient. Looking through the cracks of her cave one day, she saw the lynx making a beautiful blanket. She watched closely, learnt how it was made, and 


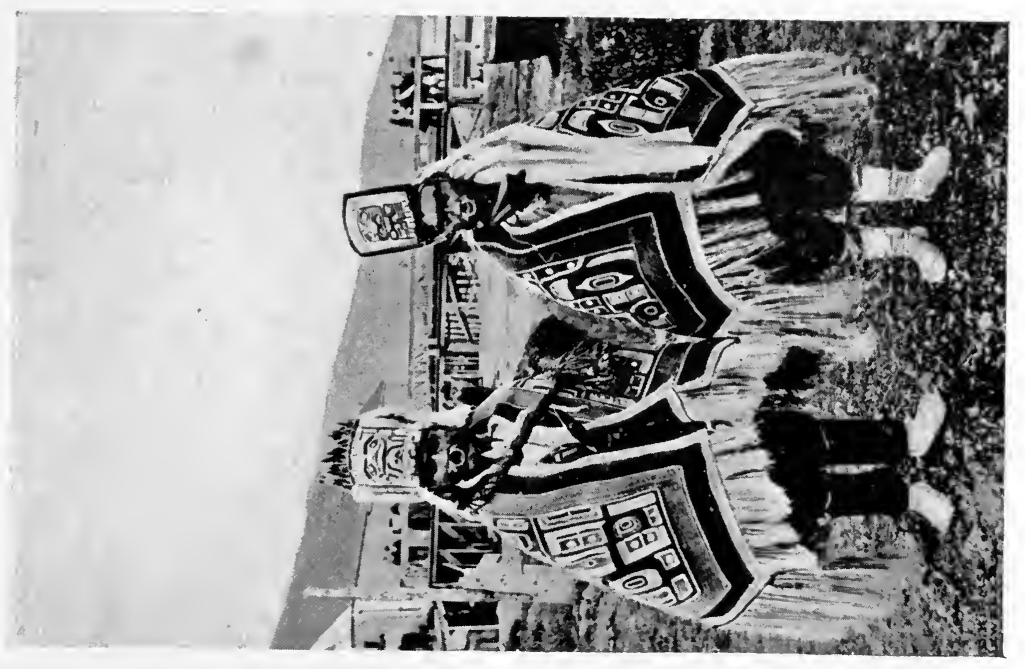

告

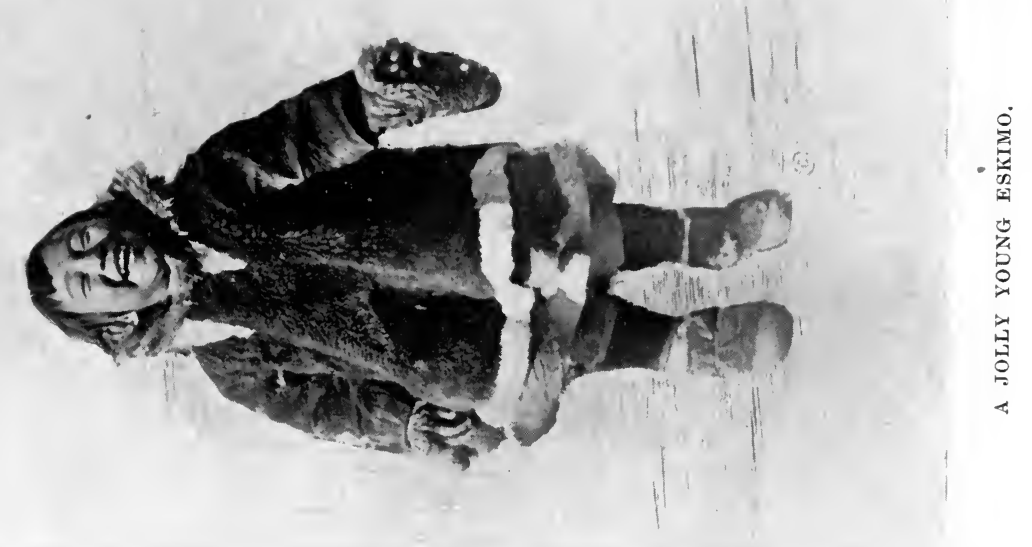



fashioned one for her husband. In time the great raven visited them in the cave, and they danced and exchanged presents. The raven, the creator-god, received the Chilkat blanket, which so delighted him that, after blessing it, he returned it to the mortals.

It takes the wool of three to ten mountain goats to make a blanket, as only the choicest of the wool is used. AAll the weaving is done entirely by hand. The general weave is the twilled diagonal, called Hee-Kar-Ree, meaning rough or uneven, like the skin on the back of a frog. The warp of the blanket is never coloured. The three colours used for the woof are black, yellow, and pale bluish-green. The colouring of the wool is effected after the thread is spun; and in the ancient days of the Chilkats, for each colour the woman who did the colouring would fast a whole day, the belief being that this ensured chromatic uniformity! There were two methods of preparing the black colour; one, a preparation from the hemlock bark; the other, from a black mud near certain springs, boiled with the hemlock bark. The yellow is prepared from a lichen, known as schoney moss, to be found on spruce and hemlock trees growing in very wet places on the mainland. The bluish-green is obtained from copper ore. There is also a blue claystone which produces identical shades. All the native colours are soft, and blend artistically. Symbolic eyes figure prominently all over the blanket to signify the presence of spiritual power. For an identical reason, Chinamen have an eye painted on their junks and sampans. "He no see without," they affirm. Every country has its own customs; if all were similar travel would lose much of its fascination.

I must hurry from curio-shops, as there are other sights to be seen at Wrangel. In walking through the residential quarter one finds pleasant-looking homes, with small gardens gay with flowers, the Government offices, an old fort now abandoned. From the higher ground the view looking down the Narrows to the snow mountains below, whilst surrounded by fragrant, flowering gardens, is uniquely beautiful. The Shaker House is the most curious sight in Wrangel, but 
Chief Shaker has passed the trail along which all mortals must pass eventually. It is a frame house of one story and a half, and before it stands two large totems, emblazoning the coat-of-arms of the Shaker family, who in their day were famous and deeply reverenced. The bear figured principally in their genealogy, although they also claim the mountain goat in their pedigree. Inside, the house is full of curios relating to the Shakers. The caretaker was said to be a descendant of the family, a nephew of the chief. One noticed a mask resembling a grizzly bear's head, once worn in bygone dances, the ears tipped with copper. They told us this mask had been worn many times by the member of the clan appointed to kill several slaves, the usual custom before a potlatch or feast. Here, also, is a queer-looking garment for dancing, typifying the woman who married a grizzly bear, with whom legend claims one of the Shaker ancestors allied herself.

A very old Chilkat blanket, hung on a wall, depicted a whale in the act of diving. There were dog-fish totems, which were supposed to be erected over slaves buried alive in Old Wrangel; several whale-killer dancing hats; and objects one had never seen before, and had no desire to see again. The Indians loved to dress themselves in handsome raiment, and ordered their serfs, or slaves, to do the menial work. The high-caste woman liked to embroider the wampan beads, to wear splendid fur robes of otter, and have her slaves wait upon her. Every clan had its chief, and proud they were of their family origin, often having the animal or bird of their totem-who was supposed to protect them from all evil-tattooed on hands and arms. This was usually done to the chieftain's children. Then the chief, who ruled absolutely, had authority to assemble the tribes and discuss important questions, whether, for example, they should, or should not, go to war with another clan. These gatherings were called "pow-wows." At such functions it was natural that they should wear their best robes, as if these were court ceremonies. Very beautiful they were indeed, made of soft tanned hides-the Indians alone understand how to dress 
skins as pliable as velvet-fringed and beaded, with painted emblems. They slung fox, martin, and ermine garments around their shoulders, and silver bracelets 5 to 10 inches in depth encircled their arms. They entwined necklaces 5 to 10 yards long about their throats, these necklaces falling to their knees. Most gorgeous were these beads, in sapphire and ruby colours, beautifully cut, no two beads being of the same pattern. They painted their faces with both red and black pigment. The women carried wonderful bags, composed of various skins, finely matched, and sewn with sinews, with occasionally a fringe of doe toes added as a finishing touch. Most interesting are these ancient shopping bags of the Indian gentry, drawn together at the top, just as ours are to-day. But in place of a ribbon they used walrus rope or a length of thin fishing-line. One of these very queer bags, which I saw and handled, was beautifully crocheted of sinews, dressed as fine as silk, and each stitch held a jade bead from the jade mountain of North Alaska! Even in those far-off days the Indians always maintained that in their country was a mountain entirely formed of jade. Arrow-heads fashioned of jade are occasionally found. The Indians certainly had an eye to effect when decorating themselves in that distant epoch.

Like the Egyptians, their funerals were great ceremonials. When a chief died several of his slaves were killed, the heir would put on the totem mask of his family and slay a number of retainers, in order that the master should have companions to join him in the other world, in the existence of which they firmly believed. The corpse was kept eight days. On the day of the chieftain's death his friends were invited to his house, these visits continuing until the burial. It was customary to offer human sacrifices, the bones being preserved and placed in a small cubicle, fashioned in the shape of a house, and placed on the grave. These receptacles were painted in gaudy colours. When the concluding feast was given, blankets, furs, and skins were distributed, and smaller gifts were received by the attendants. The widow was attired in rags, with ashes on her forehead, to signify her sorrow. 
The medicine-man was the honoured gueest, on account of his great power in this world and in the next. Not only was he a doctor but a clairvoyant as well. He appeased the spirits, both good and evil; foretold war, death; and unravelled mysteries of all kinds. It was he who indicated where lost articles would be found, and, if one of the clan happened to be drowned, where to recover the body. He was a prophet, and the natives firmly believed he could cure all sickness, prevent the approach of evil spirits, and be able to relieve them from any spell cast upon them. He would sit with the totems around him, and by his persistent, hideous, and weird cries would inspire the devils with a wholesome fear. The Indians believed that there was an Omnipotent Power who ruled their lives; that bad people died the quickest, and that the good were preserved. There were, they believed, four destinations after death. A good Indian was destined for the happy hunting-ground, where there was no trouble or pain; but before reaching this ideal spot a mighty river had to be crossed. The second destination was that allotted to the wicked, a place where the transgressor would be alone and miserable. They also believed that before the dead arrived at either place they must pass through a certain Purgatory, where they were beaten with devils' clubs, and made to suffer many hardships. Consequently, the dead were dressed in tongh, strong raiment, skin mittens being placed on their hands to protect them in their combat with the unknown. Another belief they held was, that when funeral chants were howled long and loud, that served to hasten the progress of the dead on their last journey, and cleared the way. As is the case now, and ever will be, feasting was the recreation they indulged in most. This was usually in celebration of the completion of an abode-a sort of a house-warming. Then they would send out their clansmen in canoes to invite their guests, meanwhile practising their native dances in order to be proficient. The guests would arrive in crowded canoes, and wait until midnight, when all would begin to sing and howl to announce the fact of their presence. The feasting and dancing opened with vigour, continuing through- 
out the night. At dawn presents were given to the guests according to their rank-rich furs and skins, robes of moose hide, and silver to the élite, and everyday gifts, such as blankets, cooking-utensils, and fishing-nets to the rank and file. The chief was acclaimed as a very great ruler, and eulogies of him were expounded by the story-teller, who, at such potlatches, was also a person of considerable importance. The story-teller, who invariably received some of the best presents, would tell of the early history and great deeds accomplished by the chief's forefathers. It was ever a chief's ambition to arrange as many potlatches as he possibly could, and although it left him much poorer at the end-he was supposed to give away all he possessed-every potlatch added greatly to his glory, and (human nature is the same all the world over) he was voted by his companions a real prince of good fellows! Such generosity was also supposed to oil the entrance-gates of that happy hunting-ground where every chief wished nltimately to dwell.

As the time is up for exploration, one must return to the steamer. Someone has asked me: "Do you always travel alone, Mrs. Cameron, even in the wilds of Africa and South America?" I respond, "Yes, always alone." But how untrue, because in travelling one is never alone. Whatever your destination, whatever the cliosen route, there you will find others who have a like intention. No matter how distant, or how wild and uncivilized the place, maybe you will find people on boat or train who have been there before, or who have made their homes at the spot you imagined so isolated. Soon, also, you will know all that is worth knowing about the locality- you have chosen. If yours is a personality which is not disagreeable, you will at once find friends in the University of Travel ; it will be your own fault if you are lonely. In this world, give and take, sow and reap, are truisms as old as those of the Indians.

From Wrangel to Petersburg is a run of only a few hours. Again we encounter wonderful scenery, mountains in whose fastnesses bear, wolf, deer, and fox roam at will. 
I am continually searching with my glasses for wild life up in the heights, and this afternoon thought I had located a bear standing away up on a rock. This created quite an amount of excitement amongst the passengers, and many glasses were focused. Whether it was a bear or not, it moved away before my find could be verified. What a paradise for the eagles, these white-crested, solitary mountains crowned with impressive silence! I presume before very long aeroplanes will be startling the lordly eagles, and the clatter of the internal combustion engine will become more and more familiar, as the invaders encroach upon the solitude of these denizens of the wild. Aeroplane service should prove a great aid to exploration in Alaska, more especially in the Arctic Circle, for this wild, rugged Northland is a region of great possibilities. Petersburg, although as yet a modest townlet of about 800 inhabitants, most of whom are engaged in the fishing industry, has ample room for development. The land is level, and there is plenty of space for building. At the back of Petersburg lie range upon range of mountains, rising to thousands of feet, as grandly impressive as anything Switzerland has to offer. In fact, it occurs to me that the Swiss would be rather jealous of this wonderland of snowy peaks-" all Christmas-trees and snow," as someone has appropriately described it.

There is a sharp bend, and our steamer turns. Surely there is a noticeable coldness in the air, as tiny icebergs, like phantom ships, float serenely past us. We are winding our way very slowly up what seems to us to be a Norwegian fjord. The snow-covered mountains seem to rise higher, the waterway narrows. On one mountain-side, green moss and sprucetrees add a touch of colour. On the other are dark, austere, scraggy peaks, inaccessible and grim. Look up the Taku Inlet, and you are amazed to see an enormous crystal glacier reaching to the sky, an imposing barrier indeed. This is the celebrated Taku Glacier, one of the most beautiful in Alaska, land of glaciers. Statistics assert that there are more than 5,000 in the territory, and although the Taku is so lovely, the Muir Glacier is far larger. I had seen many a glacier 
in Norway, but none could compare with this wonderful sea of frozen turquoise. Would that I had the power of enabling you to see it! Mere words are paltry in any description of Nature's grandest handiwork.

A cold wind blows, the salmon leap out of the water, flocks of wild geese, flying high, sail triumphantly over the great glacier, but the bergs claim our boundless admiration. In battalions they are now hurrying, one after the other, in their rush to join the sea, scurrying through their short life just like human souls. How beautiful they are, slightly tinged with blue. Here comes one, a perfect blue-bird in shape; a small fortress now glides in upon the scene, deeply tinged with indigo. "Look at the empty throne with seated chairs, but no king and queen," excitedly cries a little girl standing beside me. And she has cleverly described this particular berg. Two houses with an ice bridge connecting them aroused a buzz of admiration. On they continued passing, as if in orderly procession. As we approached the mother berg the blue became far more vivid. From the immense glacier which blocks the way the loose ice is melting. For this is June, and great chunks break off, tumble splashing into the running water with a thud, throwing up the spray hundreds of feet, a source of danger to small boats. Some of the blocks now drifting past us are as large as ten-storied buildings, and suggest to the imagination turquoise or sapphire palaces in Fairyland. It is now so cold that my fingers are numbed. I can scarcely hold the camera or jot down my notes. This terrific wind from the lofty mountains to the accompaniment of seas of ice is locally termed " wolleys," so I am informed by Mr. Whittier, a well-known citizen of Juneau, who has kindly afforded me much useful information. He says that the "wolleys" are detested, especially by sportsmen, who come here after salmon, or to shoot the numerous wild birds. For this is a favourite haunt of duck, geese, and loons. Tho latter are eagerly sought after, their plumage being particularly soft and desirable. Someone suggested, "We only needed a few white Polar bears to make the Arctic scene complete," and it was quite 


\section{2}

true. For now the steamer had pushed very close to the glacier, which is $1 \frac{1}{2}$ miles long and over 300 feet high, and moves ever so slowly, averaging about 10 feet a day. This is an active glacier; it has by its side a " dead" companion. The passive glacier has made no movement for 200 years, and one wonders how many thousands of years it has been in this spot, and how many centuries it will yet remain.

Unlike its beautiful "live" turquoise sister, this glacier was ugly, its ice of a solid, grey-looking hue. It reminded me of something ghostly, a veritable Lot's wife, turned, this time, into a mighty pillar of ice. Imagine, if you can, a great wide river rushing down with hurricane force. Imagine this rush of waters arrested by a whim of Nature, which commands it to "Freeze!" transforming it into a very bulwark of ice, and holding it captive. It is very seldom that one has the privilege of studying a " dead" and a "live" glacier so close together as at Taku. I picture the dark, long winter nights here, when Nature, wild, and in furious mood, hurls down the snow, and Boreas, or "wolleys," wage fierce battle against these terraced ridges of ice. Again, on a moonlight night, the scene must be nearly divine.

It was about 5 p.m., on a fine day, when we had the goodfortune to view this phenomenal pile. The captain has navigated our steamer as near the glacier as he dares go; it seems as if we were just beneath it. We are surrounded by, ice, huge crevasses are seen, and the floating bergs are immense. The passengers are crowded on the fore deck. Now the captain orders the steam whistle to be blown several times. The echoes resound over the frozen heights, and the vibration causes great aquamarine pyramids and ice blocks to topple over and fall. They hit the water with thunderous splashes, and are half hidden by the pearly spray, which reflects miniature rainbows from the setting sun. We all gazed entranced upon this fantastic beauty, and endeavoured to print it on our minds for ever, a picture of Nature dominant and unspoiled.

'To my mind, the Taku Glacier alone quite justifies a visit to far-off Alaska. 


\section{CHAPTER IV}

\section{JUNEAU, CAPITAL OF ALASKA}

VERY beautifully situated is Juneau on the Gastinean Channel, banked by lofty snow mountains. Lower down, great hills clothed in evergreen contrast finely with the glacial blue waters. Mount Juneau and Mount Roberts raise their tall peaks proudly, as if conscious of the rich yields of gold they have given to the world-some seventy millions of dollars in all. Juneau was the first to justify herself to Uncle Sam, and is referred to as a " real American city" of 5,000 inhabitants; Douglas, opposite, has 3,000. Juneau is the headquarters of the Governor and the chief officials, and has been the capital of the territory since the transference (in 1906) from Sitka, the Russian capital for more than a hundred years. The post of Governor of Alaska is an appointment of the President's. It has a Legislature composed of four representatives and two Senators from each of the four judicial divisions. This Legislature meets every two years. Each division has a District Judge and a U.S. Marshal, a delegate to Congress, and a territorial Attorney-General being elected by popular vote. The present Governor is Mr. Thomas Riggs, who has passed many years in Alaska and has a record of valuable work, especially on the Boundary Line Commission.

Upon going ashore one found everything pleasingly up to date, a town as picturesque as it is well laid out. Most of the houses are " frame", or of wood; some of them, especially along the water-front and the wharves, are erected on stilts or piles. There are a few concrete structures, and many are in course of erection. A large school has just been built at a cost of 75,000 dollars. The Court-house is notable. There are more than 15 miles of planked streets, most of them hilly. Some of the main thoroughfares are about 30 feet wide, and it is agreeable to see horses and automobiles, as in other 
capitals of the world. The streets are lively with prosperouslooking, fashionably-dressed people, the all-pervading atmosphere being one of contentment. There are all kinds of stores-one is five stories high-three department stores, jewellery, drugs, furniture, music, books, hardware, barbers and hairdressers, millinery, fur, silver, curios. Indeed, every class of shop has a place in these main streets. Juneau is a centre of politics, wealth, and commerce. Situated as it is in the richest mining district of Alaska, its future prosperity is assured.

Along the water-front saw-mills are utilizing the more than adequate supply of timber, wharves are busy with the fisheries and general merchandise. Hotels and banks have an air of great activity. There are seven well-built churches of the principal denominations, a well-equipped high-school of the same grade as in the U.S. public schools, and Government Indian schools. Herein can be observed the one great virtue in Uncle Sam. In every town or village of any size you will find a school for the native Indian. These institutions do a vast amount of good. Besides an elementary education, the Indians are taught, in addition, various trades, and the girls cooking, sewing, and home hygiene. The Roman Catholic hospital of St. Mary the Virgin is a fine institution doing noble work.

Most women are interested in beautiful furs, and as I am now in a veritable "land of furs," it will afford one an idea of the ruling prices if $I$ append this list of one of the best furriers (Charles Goldstein and Co.) of Juneau. This firm offers to trappers and dealers of the North the following prices for " number one prime furs" :

Lynx, 30 to 32 dollars.

Mink, large dark, 5 to 7 dollars.

Land otter, 12 to 15 dollars.

Cross fox, 50 to 100 dollars.

Red fox, 30 to 35 dollars.

Silver fox, 300 to 500 dollars.

Black fox, real, 500 to 1,000 dollars.

Wolverine, 5 to 16 dollars.

Wolves, same price.

Musk-rats, 75 cents to 1.50 dollars. (These are used to make our Musquash coats.) 
The fur trade from end to end of Alaska is a very great industrial factor, and one should stay at least a week at Juneau to observe it in all its aspects. I much regretted that my stay was so restricted in this interesting capital of the North. There are many excursions and automobile rides, one of the finest to the Nendenhall Glacier, about 17 miles distant, where there are fields upon fields of ice, amidst a variety of rugged scenery. Another favourite run is to the Gold Creek Canyon and to Silver Bow Basin, where waterfalls and wild-flowers vie with each other in beauty. The views from Mount Juneau, Mount Roberts, and Mount Jumbo will repay one for the climb; steamer trips to Sitka are pleasant. Naturally the greatest of all Juneau interests is the fabulously rich mines, which date from 1880 when Joe Juneau and Richard Harris came prospecting up to Gold Creek. They discovered the gold gravels, but, better yet, in Silver Bow Basin they traced the auriferous quartz. Immediately a stampede followed, and, for want of a better one, the town took the name of the elder of the two Argonauts, and thus Juneau began to be. On Douglas Island, across the channel from the mainland upon which Juneau is situated, the Treadwell Mine group was located in 1881. The three richest mines at present are the Alaska Gastineau, the Alaska Juneau, and the Alaska Treadwell. Amongst lesser mines are the Alaska Ebner, Alaska Jualin, and Berners Bay. Great future developments are prophesied for the mines in this district, as for others within the 60-mile gold belt of Juneau. The mines give employment to some 2,000 men. This is not a region for the poor prospector, on account of the high cost of living and the difficulties of clearing jungle-land and timber. The War has likewise had an influence, even in this far-away spot, on labour difficulties. Investments such as these are for capitalists- " money makes money." The Alaska Gastineau and other mines in this locality yield a low-grade ore, like those around Johannesburg in South Africa. The ore yields from 1.50 dollars to 3 dollars a ton. The Treadwell Mine, which was damaged by flood in 1917, has yielded since its foundation over $60,000,000$ 
dollars, but it swallowed a fortune to perfect its stamp mills and equipment-big capital produces big results. Take, for example, the Rand mines of South Africa. Since the mines were discovered in $1884, £ 624,366,666$ have been won from Mother Earth. Mr. D. C. Jackling, of the Alaska Gastineau Mine, reports that there is enough ore to work for a hundred years. This mine and mill during the whole of last year averaged 6,000 tons of ore daily, at which rate a mine could easily earn 5,000,000 dollars a year.

Apropos of Mr. Jackling, some six months previously I happened to be staying at the St. Francis Hotel, San Francisco. My room was on one of the topmost floors, so favoured by the sky-scraping Americans. I did not sleep we!l there, because of a wide ledge outside my windows, on which the pigeons elected to make their home. I requested that my room be changed. The attendant expostulated, saying it was an excellent room, and ended by remarking: "Why, Mr. Jackling has a suite next door to you !" I looked up with nonchalance, and asked, "Who is Mr. Jackling?" whereupon the waiter gave me a look as if uncertain of my sanity. "Haven't you heard of Mr. Jackling, the copper and gold king?' He seemed just as angry about it as if I had denied knowledge of President Wilson. I honestly replied I had not. Being English, I presume his fame was not so thoroughly well known on the other side of " the Pond." Now, as I look at these El Dorado mines, I can quite understand what a faux pas I had made by confessing to my ignorance of Mr. Jackling. When I first came to the U.S., and in the big hotels and restaurants my friends would say, " $\mathrm{Oh}$, there's Mr. X- over there; he is worth thirty-seven millions," I used to nearly dislocate my neck in an attempt to get a look at His Mightiness. But as I went farther west the millionaires and their millions increased at such a rate that I never even bothered to glance at a particularly opulent one, so satiated one becomes with this genus in America. But I am digressing, and want to tell you more about these wonderful mines. All the mines are worked by electric power. Some of the tunnels are 2 and 3 miles in length and 4,000 feet 
below the summits of the mountains. All the ore is blasted by dynamite, as on the Rand, and everyone clears out when the masses fall and tons of ore are loosened. 'Then the ore, in cars, goes to the mill, upon which millions of dollars have been spent, machinery automatically taking the place of manual labour. After the crushing and powdering processes, by means of electricity, water, and mercury, the pure gold settles, and is subsequently smelted into bricks for the, Mint. Juneau, besides being the centre of gold quartz mining, has also a very extensive fishing industry. The Juneau Cold Storage Co., the National Independence Fisheries, and Glacier Fish Co., take all the salmon brought in. The prices paid this summer were-for halibut, 7 and 8 cents a pound $\left(3 \frac{1}{2} \mathrm{~d},\right)$, and 25 cents for a whole salmon (1s. English). It is estimated that 200,000 pounds of fish a week pass through the market. There are several canneries in the neighbourhood. Mr. Ward T. Bowers, head of the U.S. Fisheries Service in Alaska, states that there are more than 200 species of eatable fish in Alaskan waters, but he admits that at present only about six species are used, the favourites being salmon, halibut, cod, and herrings. The herring industry, although it has made great progress in the past few years, has by no means reached its zenith, a rich future being predicted for it. At present the trade represented by the fishing industry of Alaska amounts to upwards of 50,000,000 dollars annually.

Agriculturally speaking, it was never imagined that SouthEastern Alaska could ever be a successful farming proposition, because of its mountains, its thick jungle, and its climate. For these reasons people have not been so ready to take up land for agricultural development, only a few availing themselves of the opportunity which the Government holds out to them. In spite of this neglect of farming interests, it has been proved that around Juneau potatoes, cauliflower, beetroot, turnips, and all hardy vegetables, can be grown as successfully as in warmer climates. Huge crops of wild berries and strawberries grow quite naturally; the flavour of the celery grown all over Alaska is excellent, and rhubarb does 
well. The potato crop in the Juneau neighbourhood yields an average of 300 bushels to the acre. Farm land can be bought from the Government for 1.25 dollars per acre. As far as forestry is concerned, this district is notably rich. Billions of hemlock-trees abound, and of spruce six hundred millions, says Mr. E. C. Erickson, lumberman of the U.S. Forest Service. The hemlock, although poor and knotty, could well be used in pulp manufacture; also there is an immense quantity of spruce, which is being turned into aeroplanes. After seeing all I could of Juneau, and patronizing a cinema show where Charlie Chaplin was doing some wonderful "stunts," I went back to the steamer. The passengers, at least those who were not exploring Juneau, appeared somewhat awestruck, and were talking together in subdued tones. Upon inquiring the reason, I was told that the divers had been working all day on the wreck of the s.s. Princess Sophia, of which everyone had read last autumn. She was the last boat to leave that season, and left Skagway with her full complement of passengers. There were five captains on board, in addition to the captain of the Sophia. They had been engaged on the Yukon River. Over eighty employees of the White Pass and Yukon Railway were coming out for the winter, and many families who had made their fortunes in Yukon and Alaska were bringing their children back to the States, and looked forward to attaining to that home of their dreams. An enormous shipment of gold was put on board at Skagway, where the steamer was seen off by everyone for miles around, as was customary. Those who were obliged to spend the long season amid the snow and ice envied their fortunate friends who were going out. Amidst "Good-byes" and laughter, the Sophia edged from the wharf of Skagway through Lynn Canal-alas! to her doom. It was very cold-freezing. All was merry on board. Then a blinding snowstorm came whirling down from the White Pass. Everything was obliterated-buoys, lights - and the wind howled like a horde of angry demons. The Sophia struck a rock and became wedged there. What happened after no one really knows, although many stories are 
circulated, for there were no survivors to tell the tale. Some said the captain shoved off the rocks and declined help, thinking the Sophia was not seriously damaged. But the rocks must have ripped her open, and as soon as she was free of them she evidently began to sink immediately; no assistance could reach her on account of the blinding storm. Thus they went down, men, women, and children, into the freezing water. Now, with the early. summer, have come the divers to see what light can be thrown upon the tragedy. They said that in one cabin sixteen people were huddled together; also that there was proof that the captain had been fired at. In one cabin a woman lay in her berth, in the silence of death, with great diamond solitaires in her ears, and beside her a bag of gold. She was said to be the heroine of one of Robert Service's poems, "The Lady that was known as Lou." The sole topic that evening was the wreck of the Sophia and what they found. Many of the bodies were being brought ashore to be buried, or sent back to their relatives at home. The tragic incident occurred in the waters between Skagway and Juneau. The masts were sticking out of the water; we would pass the scene later on, going up to Skagway.

After dinner I discovered a comfortable taxi, and drove to the Executive Mansion, or Government House as we should call it, to spend the evening with Governor and Mrs. Riggs. The mansion is an imposing white frame building, and built in the colonial style. The spacious rooms looked most comfortable and homelike. The small son and daughter were allowed to join us until their bedtime, thus completing a charming family group. Governor Riggs had spent a sad day, for he, too, had assisted in directing operations on the ill-fated Sophia. With tears in his eyes he said : "I identified ten or twelve men with whom I was so friendly that I called them by their first names."

Governor and Mirs. Riggs had recently made. a tour of the country as far as Nome, and brought back a most interesting collection of curios, which they kindly showed and explained to me. This was the first time I had seen the really fine work done by the Eskimos both in ivory, furs, moccasins, 
parkas, and other curios. One could not help admiring a life-sized portrait, which the Governor explained was a picturo of Peter the Great. Only a short time previously it had been found in a cellar at Sitka, the former Russian capital. I thought it a splendid picture, and as I have twice journeyed to Russia, I recognized the face from replicas in the museums and galleries of Petrograd. The standing figure was dressed in the imperial robes, his crown and sceptre on a table before him. Curiously enough, at his side, as if viewed through a window, was painted a ship, the landscape in the background evidently intended to represent the coast of Alaska. Historically speaking, the picture should be of considerable value.

Mrs. Riggs takes an active interest in the welfare and advancement of the Alaskan women and children. During the war she was unremitting in her efforts for the Red Cross and Alaskan charities. I regarded it as my good-fortune to have had this very pleasant evening. No one knows more of the country than Governor Riggs, who has passed many years here, and can tell you of everything of interest to be found from Ketchikan to Point Barrow in the Arctic. Upon consulting my watch I found that, owing to the pleasure of my stay, I had trespassed greatly on time, as it was 10.30 p.m., although as light as day (one would say about 6 p.m. at home). After bidding my host and hostess adieu, I entered the taxi, steamerward bound. Imagine 10.30 and the sun shining brightly as if it never would set! It is a curious sensation, when you arrive at these Northlands in June, to find that there is practically no real darkness. One never knows when it's time to go to bed. The sky is so lovely, the cloud effects enchanting. You sit chatting without any idea of time, until someone will exclaim, "Well, I think I'll retire; it's 2 a.m." We all follow this suggestion, and in the morning one must rise early in case one should miss scenery or detail. You feel tired and sleepy, until it dawns upon you that for the past week you have had only three or four hours' rest each night, so anxiously have you been watching for the sun to set. It was glorious, this extra long taxi ride all over Juneau in the golden sunlight. It 
shone gloriously upon Douglas on the opposite bank, and turned Mount Juneau and Mount Roberts into crimson trails of enchanting beauty, revealing the lace-like patterns of the snow upon the mountain-tops. In the twilight of midnight our steamer swung out into the Gastineau Channel, headed for Skagway. 


\section{CHAPTER V}

\section{SKAGWAY, GATE OF THE YUKON AND HOME OF THE NORTH WINDS}

"SkaGway!-oh, great Skagway, have mercy!" Thus implore the Indians when the Arctic wind, unleashed, hurls the blinding snows down through the Chilcoot Pass and freezes the very marrow of their bones. Skagway, or Skaguay, derived its name from an unhappy Indian princess. She was supposed to have been very beautiful, her fair face crowned with masses of Titian-red hair. Skaguay was forced to marry, without love, the son of a chief, and her husband treated her with unreasoning cruelty.

With the patience of a martyr she endured her misery. But one day, unable to bear her burden longer, she ran screaming up the mountain-side, her glorious hair streaming in the boisterous north wind. She aroused a great fear in those of her clansmen who ran after and pursued her. Then she vanished into a great rock, and was never seen again. For many years the loyal Indians placed food for Skaguay at the foot of the rock, and to this day, when the fearful storms descend on Skagway, the Indians will crave the intercession of the vanished princess.

Upon awaking early in the morning I found our steamer tied up to the ramshackle, umpainted Moore's Wharf of Skagway, the boat having pushed her nose up Lynn Canal as far as Nature permitted. Lynn Canal, by the way, was thus named by Vancouver, Lynn having been his birthplace in England. Glancing out of the porthole, the place appeared surrounded by mountains, with snow gleaming in the bright June sunshine. Skagway suggested itself at first glance as a three-cornered, rather dreary, dilapidated town of wooden houses, nestling on sands at the foot of the mountains. "So 
this is the Southern Gateway to the White Pass and Yukon," I thought to myself ; and it was difficult to imagine the thousands of souls that had poured in through this portal in 1897, 1898, and the following years, in the mad rush for Klondike gold. Skagway was the lodestar for prospectors, miners, outlaws, card-sharpers, crooks, thieves from every land. These were followed by an army of painted women, who flocked here, as vultures do, to batten on the weak. No less than 15,000 people gathered here, living in tents, shacks, or anything that would shelter them, greedy after gold, whatever the ultimate cost.

As my possessions were being landè, I was introduced to Mrs. Harriet Pullen, proprietress of Pullen House, the most celebrated character of Skagway to-day. She also had arrived in those exciting days of 1898, a widow with three small boys, and, as she herself says, "with a few dollars and one calico dress to my back." But I propose staying at Pullen House, and shall tell you of this unique establishment and its most interesting proprietress later. Mrs. Pullen was a fine, tall, magnificently built woman, dressed in dark navy serge. She arranged for my luggage, pointed out to me my place in a very old omnibus or coach, then, after seeing to all, seated herself beside me, while a pair of old horses jogged us along with a great deal of clatter. "I like horses," said Mrs. Pullen-“" used to them, you know." I replied, " There's nothing like horses." She looked me over, but we did not converse, as the noise and jolting made conversation difficult. Everyone has heard of Mrs. Pullen, of Skagway, a real pioneer, and I had met many people on the Pacific who had spoken of her courage and remarkable achievements. After a while we arrived at Pullen House. It is unlike most hotels, and has the air of a real home. As I intended staying a week, I was naturally a little anxious as to accommodation, but meekly followed this commanding woman upstairs. I tentatively inquired, "Could I not have a room below?" " No!" she firmly decided. "You're to have the Texas." At that time, being a real cheechako, or tenderfoot, I had no idea what "Texas" meant. I know now! It signifies the 
top of a house, or ship, where the best view is obtainable. And in the "Texas" Mrs. Pullen landed me. There was one huge room, a bath tub and basin with hot and cold running water tucked away in one corner, surrounded by a screen which attempted to conceal the fact; a dear, simple bedroom, and another extra room, where one could stow away luggage, etc. Most of the windows were double, and nailed up against the onslaughts of the great north wind. One I managed to open, and the view was indeed very fine-Mount Dewey, covered in white, and the A B Mountain, which owes its name to certain crevasses, which, always filled with snow, suggest the letters $A$ and $B$. Face Mountain presents classical lines of beauty to the sun. Its crest is exactly like a lovely face carved in stone, resembling nothing so much as a-Wedgwood cameo. Its neighbour, the Bear, has dissolved the snow from its eyes and nose-features created by protruding boulders-and from its eminence of 6,000 feet gazes towards the White Pass. Many other peaks stretch away in the distance as far as the eye can discern. Slowly the white mantle vanishes, as if loath to yield supremacy to a very short summer. Looking down to the town below, with its small houses and gardens, reminded me of the wooden toy villages I used to set up as a child. Losing no time, I set out to investigate Skagway. In the main street, or Broadway to be quite accurate, everything seemed invested with an air of dejection. Grass here grows in irregular patches-sure sign of decadence!-and the railwaylines of the White Pass and Yukon Railway ran through Broadway's centre. A great many of the houses are deserted, and shops are shuttered: the house decorator has been inactive for many a long day! The wooden side-walks are uneven and rotting. I pass an hotel of two stories. The Golden North : it belies its name. An Hotel Dewey is close by, but neither wears a prosperous air. There is a primitive signboard or blackboard, on which is announced in chalk a movie picture show to-night in the back of the shop. That completes the entertainment programme of Skagway! The only stone building I have seen is the Court House, which began life as 
a Methodist academy, then developed into a Methodist church, and was subsequently taken over by the Government. According to rumour, the Methodists and the Presbyterians had a series of conferences, which resulted in the Presbyterians gaining the day, as they were more powerful numerically. The Episcopal church was obliged to close owing to the lack of funds. Rents are cheap, but many people have migrated to other centres, as Skagway has no industries. The religious needs of Skagway are met by a Catholic and a Presbyterian church and a branch of the Christian Science movement.

There are several curio-shops. Mrs. Kirmse's is the best in South-Eastern Alaska, where the tourist may browse amid a vast selection of furs, nuggets, totems, Chilkat and other blankets, ivories modern and ancient, baskets of every description, walrus and mastodon tusks. The place is like a muscum, and one is not importuned to buy. Many pleasant hours I spent there, and, in addition, obtained much information of local ways and resources. Lunching at Pullen House, I met some very interesting Boston people; also Mr. Steffin, of St. Louis, a most energetic fur-buyer for his large wholesale warehouse. Most of these people were bound for Lake Atlin, as I was, later on. We had a very pleasant and excellent meal. All were enthusiastic about the wondrous thousand miles of scenery we had delighted in from Vancouver to Skagway, a series of revelations of Nature's marvels.

$\Lambda$ nd now we are in "the Flower City of Alaska," as Skagway has been called, by reason of the profusion of its beautiful flowers of enormous size, as well as of its fine fruits and vegetables. A little later in the season the mountainsides are masses of lovely wild-flowers and delicious raspberries, cranberries, blackberries, and salmon berries. An interesting excursion is across the inlet to Dyea, some 4 miles from Skagway. Here is Mrs. Pullen's ranch, with its fine herd of Jersey and Holstein cows, which provide the dairy of the hotel with fresh milk and butter. One of the pleasant and unique features of this hotel, such as I have never encountered before in my world travels, is that when you 
come down to breakfast there rests a pan of rich milk upon your table. You skim the cream yourself, for porridge or fruit, taking as much as you please. At the Pullen Ranch you are allowed to fish or shoot. It is a fine sporting centre for birds, and big game fairly abound. Dyea has its history, for from here the first gold prospectors started on their perilous journey along that relentless white road to the Chilkoot Pass, 3,500 feet of struggle and hardship. Afterwards the White Pass was discovered a little lower down, and ultimately became the favourite route, being easier to negotiate. It was called "White" not because of its perpetual covering of snow, but was named after Mr. Thomas White, who was Minister of the Interior for Canada at that time. Dyea has now lost its influence to attract. Some of the old buildings of Dyea City are still standing, but altogether it makes a visit worth while. Denver Glacier is another interesting trip. You leave by train for Denver Station, 6 miles from Skagway, and the glacier is some 4 miles beyond, and, like the Taku, of which it is a continuation, this glacier is of a most beautiful pale blue tint, due, it is thought, to consolidation and pressure of the ice.

Nearly every visitor to Skagway makes a point of visiting the graves of "Soapy" Smith and Mr. Reid. "Soapy" Smith was probably the best-known rogue in the West. $\mathrm{He}$ began his infamous career in Colorado by selling bars of soap, wherein were supposed to be tucked away a five-dollar bill. But by an ingenious sleight of hand performance, no one seemed lucky enough to secure the paper treasure. Thus the sobriquet "Soapy" Smith. Whenever a new mining camp was located, "Soapy" would be amongst the first of the stampeders. He was the prince of steerers. His photographs depict a tall, thin, handsome desperado, polite when he chose, with a fascinating personality, and a gay, infectious laugh. They say he was even charitable, and gave to the Church and the poor upon occasions. "Soapy" and his numerous gang arrived and took possession of Skagway in the lawless days of 1898 . He opened a fake Information Department, gambling-dens, and dance-halls, and 
his autocratic power knew no limit. It was said he shot first and talked afterwards! $\mathrm{He}$ had his agents on every boat coming into Skagway, even as far as Seattle. They ferreted out how much a man had, and by gambling, drugging his drink, or by means of the blackjack, the money would be taken from him. When in Skagway, those in funds would be steered to the Information Bureau, and there, by the blackjack (a pliable piece of iron covered with black), these newcomers would be knocked senseless and robbed. It was no uncommon thing for a man to come to, and find himself among a heap of senseless men. Law and order there was none. The tenderfoot was powerless, and obliged to submit to fate-in the guise of Smith and his minions. As fast as one lot were "cleaned out" of their finances, others were arriving. Thousands were pouring in in the hope of making a fortune, and wonderful stories were circulated of nuggets, thousands of dollars in value, picked up in Golden Klondike as quickly as one could handle them. "Soapy" was known throughout his "territory" as the King of Terrors. He was supposed to be loyal to his followers, but merciless where money was concerned. Thomas Jefferson Smith and his gang of bandits included a choice assortment of desperadoes bearing such "picturesque" cognomens as " Yank Fewclothes," " Kid Jimmy Fresh," " Fatty Green,", and others who have long since ambled along the Sunset Trail. Yet their memory remains as terrors of the past. For years " Soapy" was the prize Bunco Prince, and his crooked dealings were masterpieces in villainy and bravado. All feared him ; his revolver was ready on the instant ; murder, in his eyes, was nothing; and he shot straight! He was very extravagant, poured out money with the ease with which he acquired it, squandering it largely with his gang. His gambling establishments and dance-halls were superbly fitted - silver, cut glass, rivers of champagne, and every luxury this brigand could command and commandeer. After a time the citizens decided that something would have to be done. The name and fame of Skagway had become so tarnished that men would prefer to get through to the Klondike viâ Atlin, 
Stikine River, and other routes. A Vigilance Committee was formed with the intention of ousting "Soapy " and his gang. Frank Reid was one of the heads of the counter-organization, an engineer and a determined man. A meeting was to be held at one of the wharves, at which all citizens were invited. Reid stood at the entrance, armed, to prevent "Soapy" or any of his satellites attending in order to learn of and frustrate their plans. "Soapy," meantime, had been drinking heavily. Securing his revolver, the bandit made for the wharf. Reid stopped him; warned him ho was not to be admitted. They then fired at each other simultaneously. "Soapy." instantly dropped dead. Reid was mortally wounded, but lingered for some days. Thus ended dramatically the career of "Soapy." The gallant Reid and his victim are buried in an abandoned churchyard about $2 \frac{1}{2}$ miles from Skagway, not far from each other. On "Soapy's" simple wooden board is painted "Jefferson R. Smith, died July 8, 1898, aged 38 years." Over Reid's body is a costly granite tombstone, upon which is carved " Frank H. Reid, died July 20, 1898. He gave his life for the honour of Skagway." " Soapy " was such a noted character, his evil fame had travelled so far, that for years tourists would visit the grave and slit off as souvenirs a piece of the wooden sign on the grave. On seven or eight occasions the sign has been replaced, but now it would seem that Nature herself has decided to obliterate the memory of the greatest tragedy of those golden days, for a landslide has nearly wiped out the spot where the desperado lies. With the death of "Soapy" his gang realized that the game was up, and they speedily scattered in all directions. A few were punished, and Skagway became respectable and law-abiding. The Arctic Brotherhood, a fraternal society, was established by the Americans and English as a protection against lawlessness in the old days. It is now more of a social club, and has its first camp, No. 1, at Skagway, built in rustic style, with "A.B." over the doorway. It is a peculiar coincidence that the mountain with the natural "A B" formed out of snowfilled crevasses is just behind the premises. The Arctic 


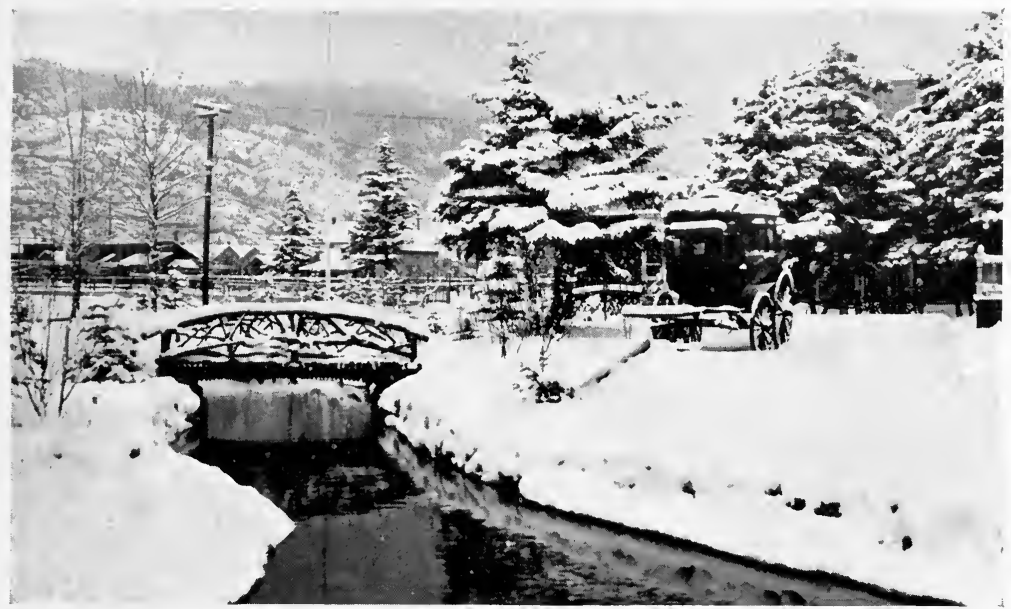

PULLEN HOUSE GROUNDS IN WINTER.

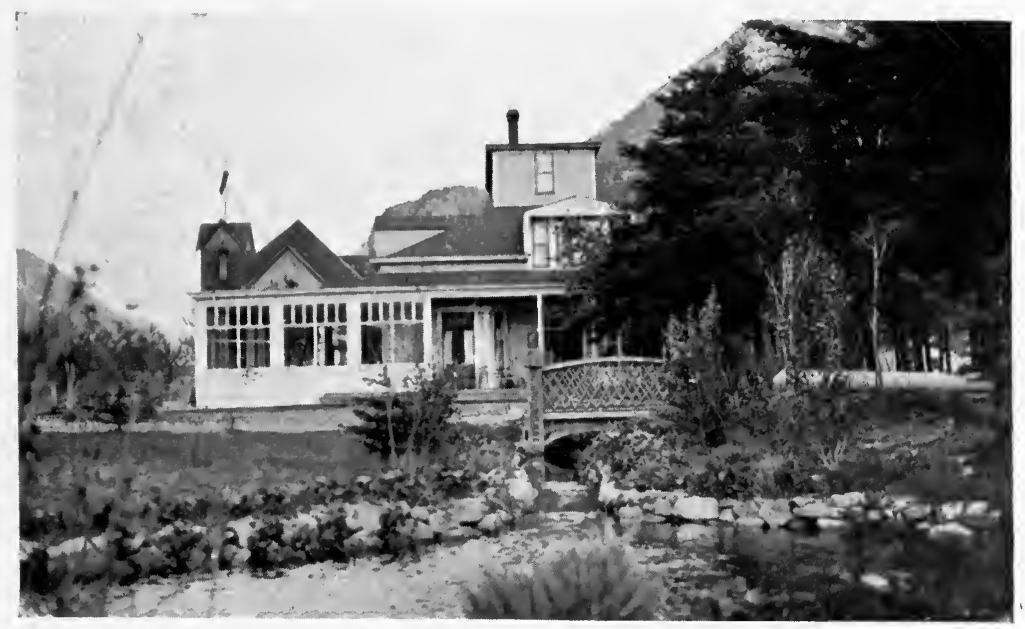

MRS. PULLEN'S ORIGINAL HOTEL, SKAGWAY. 

Brotherhood has done an immense amount of good all over this great Northland, and you will find their offices in every town of any size, both in Alaska and the Yukon. It is indeed a brotherhood. The Elks also have a fine hall, three stories in height. One and two storied buildings prevail at Skagway. One notices a sort of "false-front house," and sees them frequently in this region. They are in reality one-story houses, the front of the building so arranged as to suggest the possession of another floor. It is, in reality, a sort of camouflage, and a very ugly idea it is-striving to be something which it is not.

Mrs. Pullen lent me an old newspaper dated Dawson, July 1st, 1896, with The Klondike News in large gold letters; it was the first edition. The front page depicted teams of dogs drawing a sleigh. In the centre a picture of George Carmack, who first discovered the gold. All around the sides of Carmack's picture are huge blobs of gilt, representing nuggets. Here are some of the announcements:

"The largest gold nugget found in El Dorado Creek weighed 35 ounces, value 530 dollars. Found by M. Kunston.

" Another nugget from No. 8 property of Charles Lamb, value 315 dollars."

Below are restaurant and other prices of those days:

Bowl of soup, 1 dollar.

Beans, bread, and coffee, 2 dollars.

Dish of tomatoes, 2 dollars.

Champagne, 30 dollars.

Steak, 5 dollars.

Piece of pie, 1 dollar.

Doughnuts and coffee, 1.25 dollars.

Whisky, 50 dollars a gallon.

Team of horses to work, 12 dollars an hour.

A pick, 17 dollars.

Socks, 8 dollars.

Small bag of salt, 5 dollars.

Window-glass, 50 dollar's for a small pane.

The list simply gives one an idea of the cost of things in those early days, but when one remembers the many miles of cartage through snow-passes, lakes, rivers, and rapids, these inflated rates are easily understood. 
Skagway has an up-to-date water-works, telephone and electric light services, a daily newspaper, and one can be thoroughly comfortable at Pullen House, where Mrs. Pullen is a host in herself. The hotel is of three stories, containing some twenty rooms, in each of which is hot and cold running water, most of them with private baths. There is a sun parlour with glorious views-myriads of birds make musicand a huge fireplace built of native rocks. In the grounds are two tront streams, and a miniature island connected by rustic bridges and stepping-stones. In addition to the hotel itself, there are several cottages or annexes, where families can find a home, coming into the hotel proper for their meals. Prices range from 3 dollars to 10 dollars a day inclusive. In the curio-room are countless souvenirs collected by Mrs. Pullen, reminiscent of the great gold rush, and she has many relics of the notorious "Soapy." In the living-room is a table which belonged to the demon chief, upon which many fortunes have been won and lost-mostly lost. It was a round table fashioned of two pieces of oak. Although it appeared to be perfectly solid, there was just a slight opening, hardly visible to the average eye, at each side, into which a card could be slipped, so that in a game of poker a flushwell, a royal one-could be procured. By a quick move of the hand, an extra ace.would be found within the " accommodating" slit. There was also an expensive Crap table and a splendid and enormous roulette-wheel with counters. If these inanimate objects could talk, what terrible revelations they would disclose! One was also shown knuckle-dusters, handcuffs, and a blackjack. All had been the property of " Soapy," as well as an elegant cut-glass punch-bowl, with decanters and glasses.

One afternoon Mrs. Pullen asked me into her treasurerooms. I had no idea I was to see such a wonderfully interesting collection; to hear her talk and describe the old days excelled any theatrical performance I have ever attended. She was a widow, and had to make a living for herself and her three little sons. Having been brought up a great deal with the Indians in the Northern States, she knew several 
of the tribal languages. She was also familiar with horses, and able to handle them. In those early, golden days a great deal of money was to be made out of freighting-that is, carrying packs and stores. This remarkable woman of courage and energy used to drive a four-horse team up the pass to White Pass City. She told me that some mornings her arms were so lame and stiff with continually plying the brakes that she would have to take each arm and work it up and down to get it in bendable order. After working all day, at night she would cook for the men and sell pies and cakes. She had no friends; the three children were her sole companions. She was, and still is, a handsome woman of fine physique. The rough men wondered at her. "Soapy" himself watched her, laid certain traps which came to naught. Then he regarded her as a Government spy, and told her this himself as they became better acquainted. She was present when "Soapy" met his end. Another thing excited their curiosity-she would always remain a teetotaller. Men would arrange dinners at her then humble place, and as an amusement offer her their pokes of gold if she would drink with them. She told them that she did not want her sons to drink, therefore she never touched a glass of wine or spirits herself. And she hasn't to this day!

Unlocking an old Indian box, she shook out an ermine coat elaborately trimmed with fringes and wampum Indian beads. This had belonged to one of the great treaty chieftains, whom she had nursed; he left her some of his priceless possessions. I cannot recall having seen such wonderful beads! Mrs. Pullen held them up, long strings of them, to the light, sparkling rows of sapphire, amethyst, and ruby-coloured glass over a hundred years old. They dated from the time of the Russian occupation. Some of the necklaces were 10 yards in length, each bead remarkably smooth, cut by hand, and of a different pattern. There must have been a hundred yards of them in all-a treasure indeed! My hostess next disclosed the enormous feather head-dresses of the chiefs she had known; leather robes and jackets as soft as woollen, embroidered with beads in exquisite workmanship ; long earrings 
of beads, jade, silver, and gold ; bags of cedar bark, moose hide rugs, a medicine-man's mask, the first flag that flew over the Chilkat Pass, a bridle made in Mexico of horse-hair finely woven, Indian money of ancient days, and a tobacco-pouch fashioned out of a white swan's foot. She dressed, to oblige me, in an Indian princess's robe, and with her tall figure and commanding grace she looked the part. Meantime, without affectation, she related to me the most interesting of stories and recollections. This gifted woman has no idea of her original charm and power. Her laugh is contagious, and she is as simply natural as a child. In those old days it was most difficult to secure household utensils. She showed me, for example, the dustpans she had hammered out of tin cans! Glasses were either very expensive or not to be had at any price. They therefore placed a string-which had been dipped in coal oil-around the broadest part, then ignited the string. This unique process would cut the bottle as with a knife. They would then grind the rim of the bottle in the sand, making it entirely smooth, and a perfect drinking-glass was the result. She showed me several. So much for the ingenuity of the pioneer! Her collection of copper, brass, old Russian silver, and ivories is exceedingly fine-in fact, she has so much that is intensely interesting that it would fill a good-sized museum. I begged of her to arrange these relics of the past in one of her cottages, and present the entire collection to Skagway, in order that future generations might enjoy the sight of them, and take the donor as a model. Mrs. Pullen gave to the war two sons, Colonel Pullen and Captain Royal Pullen, who have covered themselves with honour. Her youngest son was drowned at Juneau. The reputation of the family has extended far beyond the Skagway borders, for General Pershing once said he wished he had a regiment of Pullens! Colonel Pullen, by the way, was the first Alaskan to enter West Point. Many years ago, when the cadets heard that a chap from that far Northland had arrived at West Point, they concluded he must be an Eskimo, and were by no means elated at his admission to their exclusive training centre. They prophesied all sorts of awful things 
for the presumed uncultured Eskimo! At a big football match they met Pullen, at that time an enormous red-headed chap. " Some Eskimo!" admitted the boys, laughing. They asked him what he knew about football. He replied that he had played. They offered him a minor position, as a joke. The game, as it proceeded, was clearly going against them. Then the "Eskimo," as they had christened him, went in, played for all he was worth, and their team won. After that he played right tackle in the West Point team for four years. He stands 6 foot 3 inches in height, and, like his mother, is a fine specimen of humanity. In the Great War he has risen to be a fully fledged Colonel, and gained the Distinguished Service Cross. Many paragraphs in the newspapers tell of his valiant service: these his proud mother regards as priceless. Captain Royal Pullen, of the 28th Engineers, also gained several honours. Such pioneer mothers as Mrs. Pullen, who drove her horses over the icy trails, who worked harder even than a man, who gave fine, upstanding sons to her country, set a noble example. Thousands of most distinguished people from all parts of the world have met Mrs. Pullen, and her personality will stand out distinct after many another has faded.

It is the 21st of June, the longest day. From Fort Yukon, on the Arctic Circle, the sun will not set to-day. Those who are fortunate enough to be there will watch the sun skim the horizon, the one day upon which King Sol is at home throughout the twenty-four hours. In this part of the world a midnight sun festival is a recognized event. Hundreds of people, hailing from all parts, left Skagway by train at 5.30 this morning to spend the holiday at White Horse. All kinds of sports are to be indulged in, and, saith rumour (though let us whisper it), whiskies and wines can be purchased for this annual celebration. Through this part of the country prohibition holds unrelenting sway, but the Yukon has not yet gone " dry," this event having been postponed until the end of August. Many Alaskans are therefore hastening to their appointment with Bacchus, for alcohol will soon be but a memory. 
In the early hours of the next morning the excursionists were again set down at Skagway to depart on their various journeys. The train passes close to my open windows, and from the boisterous sing-songs and the general hilarity of the crowd it was obvious that they had kept their appointment to the letter. Another of Skagway's diversions is the attraction of camp life at Burro Creek. Here, amidst gushing waterfalls and flowering canyons, with twenty-two hours of daylight to add to one's pleasure, you have an ideal rustic retreat. Should you carry a gun, you may feed upon delicious Alaskan blue grouse. Wild duck and geese are plentiful, and many a fat ptarmigan may tempt you. Fish from the streams and King Salmon shall be added to your menu. With this fine natural larder ever at your disposal, you can live like a Lucullus. With its fresh, exhilarating mountain air, what a health-giving retreat this haven would be for the weary brain-worker! For here is renewed life, an environment of peaks, glaciers, canyons, with an ever-changing picture to feast upon. I can scarcely realize, so quickly has time passed, that I have been a whole week at Slagaway. Regretfully I leave my Texas with its glorious panorama, and say good-bye to Mrs. Pullen, doyenne of hostesses, and continue my journey over the White Pass. 


\section{CHAPTER VI}

\section{THE WHITE PASS AND CARCROSS}

I Now mount the train and secure an outside seat on the observation-car of the White Pass and Yukon Railway, en route to Carcross, or Caribou. The latter name was favoured by the Indians on account of the enormous herds of caribou which year by year crossed on their stampede north. So numerous, it was said, were these migratory herds that they sometimes took as long as two months to cross-a continuously moving caribou army.

People in England would be amazed could they see the railway trains in this part of the world. They are far better equipped than our own. In the observation-car, high, spacious, and airy, electrically lighted, with large plate-glass windows, and with comfortable wicker armchairs upholstered in green plush, comfort is the keynote. All that is expected of the passenger is to enjoy an ever-moving picture of Nature in her wildest moods. Thus I left Skagway, which, after her tempestuous youth, has now settled down to a most respectable middle age of law-abiding dullness. The train passes slowly along the Broadway, leaves the hospital behind, and enters the canyon almost at once, beginning its stiff ascent of rugged mountains, hanging rocks, and precipitous inclines, whilst the passenger gazes spellbound upon the feats this wonderful railway has accomplished. The White Pass and Yukon Railway was begun in 1898, at the zenith of the Klondike rush, and it is scarcely believable that the railroad pioneers could, in so short a space of time, have conquered what was freely said to be unconquerable and beyond human power. The first railway built in Alaska, its length is 111 miles, and its route is over the White Pass to White Horse. Its construction cost many lives and many millions of dollars. 
The first 20 miles averaged more than 100,000 dollars per mile, but the first train brought out 2,000,000 dollars' worth of gold. Over 3,000 men worked in all weathers and seasons, night and day. In some places, where the cliffs are perpendicular, there was no foothold: the workmen had to be suspended in slings from above in order to enable them to drill and blast out ledges wide enough to form a space for the road. This wonderful road clings to sheer rock, ever mounting, and winding higher and higher along the canyon cut out by the Skagway River. At first the hillsides are green with vegetation; wild flowers, in reds and golds, sprinkled with blue lupin, impart a fragrance to the crisp mountain air. As we begin the climb the grey-white glacier waters of the river, made whiter by the grinding of the granite in its long leap through the boulders of stone, foam and scurry downward to Lynn Canal. Soon we are above the tree-tops, and we gaze curiously as gorge after gorge meets our astonished eyes. We proceed along a surface of hard granite, the largest compact mass in the world, climbing a 4 per cent. grade through this terraced rock, which has been swept smooth and polished by the glaciers of centuries. From Box Canyon parts of the old trail are seen-a few rotting logs, a forsaken, dilapidated shack-then grass and bushes obliterate the trail, along which thousands of Argonauts toiled and suffered untold hardships in days when the treasure of the Klondike beckoned, and men thought only of gold. Looking towards Skagway, the silvered mountains and blue waters of Lynn Canal form a pretty picture. The White Bear, on Bear Mountain, watches you all the way up the Pass. The hanging rocks of Clifton threaten to crush us as we rush by. Only two years ago there was a fall of one of these immense boulders. The engine was pushed off the embankment and hurled below, killing the engineer and fireman; but the train, with its passengers, remained on the rails, and no one else was hurt. A terrifying experience! At another point, when the road was being made, a great flat rock fell, crushing and killing five men, who still rest under their mighty tombstone, a cross now marking the spot. Many small crosses, or just two sticks, 
signify the grave of some courageous one who fell by the wayside, and never reached the El Dorado on this earth; but one hopes he found it in the other world. The train rounds the curve, and the remains of deserted White Pass City come into view. Here more than 3,000 people lived in the days of the rush. We now have a look at the snowy, foaming cascades of Pitch-Fork Falls, which have dashed down some 3,000 feet from mountains that seem to embrace the sky. Ferns, mosses, and a few varieties of wild-flowers essay to live along the borders, continually sprayed by the waterfall; a woodchuck leaps out to introduce itself, and small grey squirrels are constantly seen. Once more the old Klondike trail is visible. One can imagine the men and women, pushing on with crazy impatience, braving all dangers and hardships. In the winter, when 40 and 50 degrees below zero is registered, they cared not, only prayed to live to get there and stake out their precious claims. I do not suppose any of them ever paused to drink in the sublime panorama around them. Bridal Falls flings her misty diaphanous veil over black boulders as if to soften their awe-inspiring grandeur, as she leaps downward and joins the Skagway River. Sawtooth Mountain looms high above us, disclosing its bare weather-beaten peaks, and away down there in the canyon is Dead Horse Gulch, where thousands of worn-out horses and mules, unable to withstand further hardships, left their bones to whiten with the snows. From sheer exhaustion they fell, rolling down into the gulch from the trail above. Some will have it that these poor uncomplaining beasts, so heavily laden, committed suicide at this particular spot. Freighting was expensive, and as a consequence packs weighed up to the last pound a beast could possibly carry. We enter the only tunnel on the line, 250 feet long, and as we emerge into daylight we obtain from Inspiration Point our last view of Skagway, surrounded by her protecting mountains-a magnificent spectacle $\mid$ The steel cantilever bridge is a wonderful structure, 215 feet above the canyon it spans. As one crosses, another view of the old trail is obtained, whilst the dreaded Dead Horse Gulch seems from this 
height even more formidable. Now we near the summit of the White Pass, 21 miles from Skagway. This marks the International boundary, where the Stars and Stripes and the Union Jack float together, a few feet apart. May they ever stand united for the benefit of humanity and the world!

Here also is Summit Lake. It is small, not much bigger than a good-sized pond, and full of dirty, half-melted snow and ice, for there is much snow about the summit. Here the waters part: one stream flows south, to the Pacific; the other has a journey northward of 2,200 miles before it reaches its destination, the Bering Sea. It is a branch of the Yukon, one of the four longest and mightiest rivers in the world, and it is with the greatest curiosity and interest that I regard its slushy waters, a mere stream-the Yukon in its unlovely infancy. The reason why I gaze with apprehension and wonder upon this baby stream is because I propose to follow its full course, to acquaint myself with its entire life, from its ignominious birth in the summit of the White Pass to its glorious death in the Bering Sea.

Will you come with me, my readers?

The scenery broadens in outline. We pass valleys, small turquoise lakes, fields of wild-flowers, palisades of grey-green spruce-trees. Overshadowing all are the streaked mountains, patterned with many a quaint snow design. Some appear as if an antimacassar had been spread over the top, the edges hanging over the sides. The Yukon affects soft greys and pale blues, mingled in delightful symphony, tints which I have seen in no other land-they are indescribably beautiful. The heavy, solidly built snow fences that protect the snow from drifting make one realize what mighty storms must riot on this summit in winter. The trains, with their powerful snow-ploughs, manage to push their way twice a week to White Horse in the depths of winter. The conductor assured me that often the snow would be piled up to the top of the windows of the cars. The train pulls up at Bennett, where we stop for luncheon. Half an hour is allowed, and a very good meal is served for one dollar (4s.).

Bennett, named after the famous American, James Gordon 
Bennett, is a deserted place, but in the days of 1897 and 1898 was a city of several thousand people, and for a time was the terminus of the railway before it was continued to White Horse. It was at Bennett that the gold-seekers rested after their unbelievable hardships over the trail, and built boats to take them across Lake Bennett and down the Yukon to Dawson or Klondike.

Tundra is pointed out to me for the first time. This is a soft, spongy undergrowth, through which weeds and wildflowers protrude, and is most difficult to walk through. In some parts of the Yukon there are thousands of miles of tundra, and very little else. Much has been written of the sourdoughs mushing through the tundra on prospecting bent.

Many people differ as to the exact significance of the term "sourdoughs." The real sourdough is one who comes from the pioneers, the men who mushed through the country prospecting, looking for gold. These were of necessity their own cooks. They carried their " grub" with them ; by their camp fires they stirred up flour and water and baked it, like the Scotch do a bannock. Now, this breadstuff was much improved by the addition of a little yeast. Pioneers, therefore, always carried a small piece of sour dough in their pockets to mix with their bread. Hence the sobriquet, a name that has always stuck to them. In more recent times people who have remained in this vast Northland and witnessed one winter's ice break up, also claim to be sourdoughs, but they are not " the real thing." The opposite to a sourdough is a " cheechako," meaning a tenderfoot, or someone just arrived in the country. One travelling in Alaska or the Yukon soon becomes familiar with both cognomens, the traveller being likened to one or the other.

The train now skirts Lake Bennett for 27 miles. The lake is narrow, and the mountains, rising direct from the water, soar to 5,000 feet. Their colour is old rose, which reflects delightfully in the placid surface of the lake. Bedeck this natural mirror with borders of wild-flowers and you have the pieture complete. One is loath to leave this most comfortable 
of trains, but at the northern end of Lake Bennett lies Carcross, my present destination.

After alighting, I look around at a well-kept little station, and am pleased to be " at home," for the Union Jack is flying over this small nest of a place. There appears to be a narrow stretch of sand, with Lake Bennett on one side and Lake Nares on the other. The mountains on one side make me shudder, they are so dark, grim, and forbidding. Some very pleasant Customs officials talk to me. I have nothing to declare, having already been asked at the summit. So my word was taken. Without being unduly partial to Britons, I must say that I consider we have the nicest Customs officials in all the world. In many ways we are far behind the Americans. In our housing accommodation, our sanitary methods, our train systems, we do not set the pace; but in arriving at a British port one's word is accepted ten times out of a hundred. On the American side, however, they involve you in all the trouble they possibly can. A favourite method of their Customs is for a man to put his two big hands right down tc the bottom of your trunk, then scoop up its contents, with the result that everything bulges in the centre. He then gives you an expressive grunt, as if annoyed at having failed to discover anything dutiable. $\mathrm{H}_{\odot}$ then struts off, never deigning to offer to help you close those trunks he has so ruthlessly disarranged. You struggle with your trunk, and do the best you can to relock it, saying a few complimentary things under your breath.

Opposite the station is the Caribou Hotel, which I enter. Mr. and Mrs. Gideon are the proprietors. It is clean and comfortable, not at all a bad place; the food is good. Mrs. Gideon has some fine skins and native curios. On the wall in the sitting-room was hanging a magnificent skin of a silver-pointed bear; it had been shot near-by, and measured 9 feet long and 4 feet wide. I am now in the very heart of the fur country : these mountains are the home of fur-bearing animals. Mrs. Gideon took me into an outer room, where dozens of huge timber wolf-skins were hung, ready for sale. Grey in colour, they come from the largest of the wolf family, 


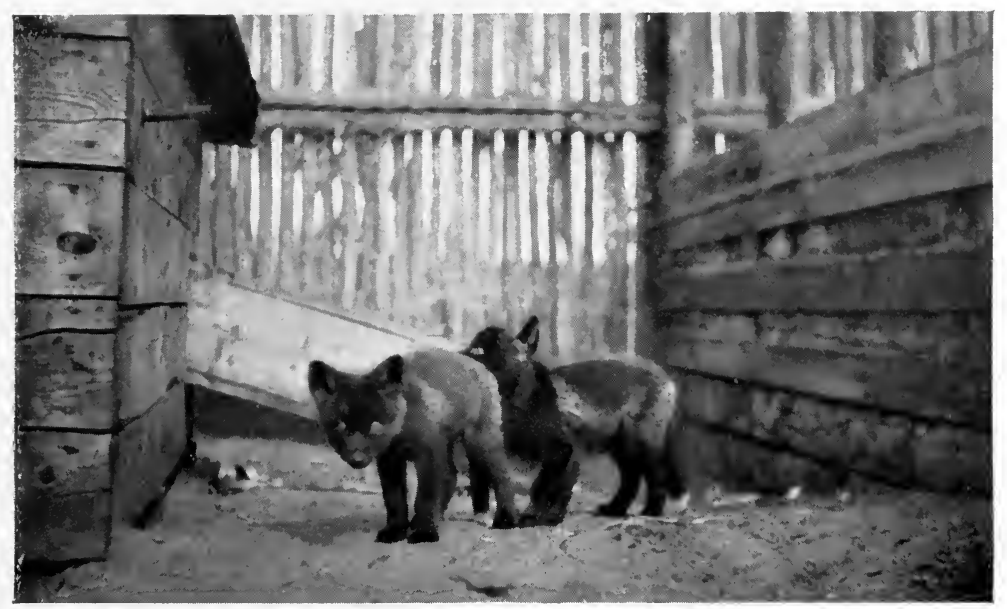

SILVER FOX FARMING, CARCROSS, YUKON.

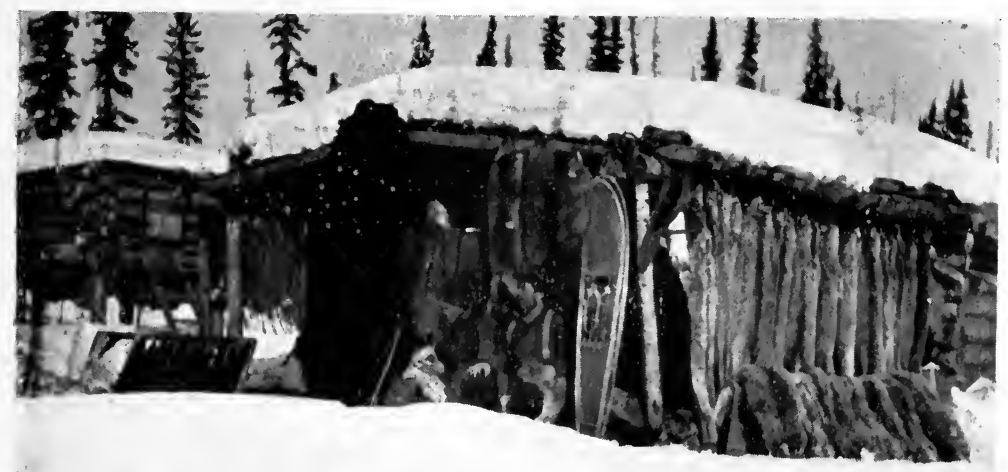

A TRAPPER's CABIN WITH SNOW-SHOES AND PELTS. 

and are from 80 to 90 inches from nose to tail, and 20 inches across. They are one of the most difficult animals in the world to trap, as are their brothers, the coyote. Human odour they detect immediately. The most successful prelude to catching them is to dip the traps in blood, or to smear mutton tallow or beeswax over them. The traps should be handled with gloves. As the wolves naturally follow sheep or cattle trails, the traps are set by the professional wolf trappers just where those trails meet. Occasionally the traps are baited with strychnine, disguised in a ball of tallow the size of an egg. At Carcross, and all around this district, are many fox farms, a comparatively new industry, which some have found very successful. They breed the beautiful silver foxes, the red, the crossed fox, and formerly, the rarest of all, the black fox. In the old days any trapper fortunate enough to get possession of a black fox considered his fortune made. Now that the breeding of the black fox, although they are very difficult to rear, is a veritable commercial proposition, coupled with the very clever manner of dyeing fox and lynx, the value of the black fox has decreased considerably. The silver foxes, which are very beautiful and fashionable, fetch an enormous price, according to size, colour, and quality. I was very anxious to visit a silver fox farm, for there were quite a number about here. We rang up-observe the up-to-date touch-a farmer to inquire if we might come over; but he replied that he dared not just then, as one of his best silver foxes had given birth to a litter. They are very nervous, wild, and shy. At the least disturbance they become very excited, and a mother will often eat or kill her babies. The next day, however, the genial Customs official, who had a fox farm of his own, was good enough to let me see his foxes, a photograph of which you will see. First I visited his pretty log house, or cabin, as they are called all over the Yukon. My entertainers were Scotch, but had been many years in the country. I found them genial and most hospitable, and more than ready to chat about Old Scotia. A very pretty young daughter graced the scene. Carcross consists of perhaps fifty houses, mostly log 
huts, well built, and plastered between the logs to make them air-tight and warm. The winters are cruel here; the icy winds swoop down relentlessly from the White Pass and frozen lakes. There are three or four small shops, and postal, telegraph and wireless facilities. Its principal industries are mining, fishing, and trapping of furs. Also, it is the junction for Lake Atlin. A celebrated Indian school lies just outside Carcross, and every day you will see the teachers with their columns of Indian and half-breed children taking a promenade, just as on the East Coast resorts of England. These schools, as in other parts of Alaska, are excellent in every respect. Lake Bennott forms a part of the boundary between British Columbia and the Yukon. From Carcross one takes the steamer to Atlin, B.C. One drawback to travel in this country, and in Alaska in general, is that you are never exactly sure of the steamers. They are scheduled to sail at certain times, but time, tide, and weather cancel many sailings, and this year there is a lack of transport facilities. Therefore it behoves a traveller to be at the beck of the steamer officials, ready. It's for you to wait; especially is this so farther up into the country and the upper reaches of the Yukon, where, should you lose one boat, it is possible you might have to wait a whole month in some remote spot before being able to catch another steamer. As the cost of travel is an item of interest, the following tariff will give some idea, although subject to continual changes :

\begin{tabular}{|c|c|c|c|}
\hline From Skagway to Atlin $\quad$... & & & dollar's. \\
\hline From Skagway to White Horse & & 20 & \\
\hline From White Horse to Dawson & & 35 & ,, \\
\hline From Dawson to Tanana ... & & 40 & \\
\hline Tanana to Fairbanks and back & & 50 & , \\
\hline From Tanana to St. Michael & ... & 53 & ," \\
\hline St. Michael to Nome ... . & & 25 & , \\
\hline
\end{tabular}

The Americans also add a war tax of 8 per cent. These prices include food on the steamers. On shore you naturally pay your own hotel bills. On the averagé, rooms range from 2.50 dollars to 4 dollars, meals extra-usually, 1 dollar for breakfast and supper; perhaps 1.50 dollars for dinner, or à la carte a little more. All else is extra-baths, teas, and so forth. 
At Seattle the shipping companies issue a ticket from Seattle, viâ the Yukon, Nome, and back to Seattle, for something like 260 dollars, excluding war tax. This rate does not include Atlin, nor Fairbanks. On the whole, it is not expensive on the boats. But on land things rule high, owing to the distance, expensive freight rates, and lack of transportation. At Carcross I went into the general store to buy a moose hide. In the hotel I had remarked a very effective table-cover of moose. They are large, of a tan or brown colour, made flexible by the clever dressing of the Indians. Some are stamped with a figure of the moose and a background of spruce-trees, its natural surroundings. The keeper was busy selling canned goods to a group of Indians, who stopped all buying at sight of me. I, on the other hand, was just as much interested in them; so we looked attentively and critically at each other's clothes. They pointed to my hat, which had a weird stiff feather on it. I examined their beaded moccasins, and thought how comfortable they looked. We smiled a good deal; smiles seemed more comprehensible than words. They showed buckskin shirts, pockets, and baskets, all trimmed with beads and fringes. With these curiosities they would barter vigorously and procure sufficient food to last them all winter. It was evidently a festive occasion, for these Indians (of the Stick tribe, who have many settlements in this district, as well as along the Yukon) had probably walked 20 miles that morning to get to Carcross. The two braves motioned to the squaws to "come on," so, with a smiling " come back," to the dealer and myself, they stalked out. The storekeeper and I had a long talk about Indians and their peculiar ways of life. " A group of them," he said, "or an Indian singly, will come into the store, and practically remain the whole day, lounging about. He will point to a can of peaches, exclaiming, 'Peaches!' then he will buy and pay for them. After a while he will shout 'Flour!' The bag of flour is taken down, and the Indian again pays. Thus it goes on, until his entire wants are supplied, each article chosen and paid for individually." The Indians marry as follows: Between the ages of eighteen and 
twenty, a young brave will choose for his wife, or squaw, a mate older than himself, a widow if possible, because she knows how to cook, run the shack, tan the skins, make mats, sew moccasins, and snare a bird. A squaw also prefers a husband younger, as he will be more of a " rustler" - that is, getting out and after things, like trapping and fishing. Then this-as they appear to us-ill-assorted couple, afterward solve their matrimonial problems agreeably. When the man finds his wife tiring in the general family work, he sets the first wife aside, and weds a younger one. But he does not absolutely forsake the first; he is supposed to be kind to her, and by his gun supply her with meat and other food. The Stick Indians are also very fond of giving potlatches, and many a chief has found himself reduced to penury by this, an extravagance to which reference has already been made. They tell me that the Indians have a sweet tooth, being very fond of candy, chocolates, and preserves of all kinds.

There is nothing much to do at Carcross, this small settlement of log cabins. The sand oozes into your shoes if you step off the shaky, rather broken board-walks.

Upon going back to the hotel, someone suggested, "If you want local colour, why don't you go over and see Kate Carmack ; she is living on the other side of the lake." Being rather bored, this struck me as a brilliant idea. But before we interview Kate, the Indian wife of George Carmack, we shall need an explanation. Some claim that Carmack was the first discoverer of gold on the Klondike, and others accord the honour to Bob Henderson. The most romantic version is that George Carmack, who had been a rancher in California, was on a fishing trip, accompanied by Kate, " Skookum Jim," and "Takish Charlie." The latter wero good hunters and trappers, and lived by their guns. One day, Kate-sister of "Skookum Jim "-went down to the creek to get a pan of water to wash the dishes. When she scooped up the water, she was surprised to find at the bottom of the pan a lot of big nuggets. Immediately she ran back to Carmack to show him the gold. Carmack and his two "pals" rushed down to the creek, and found the heaped-up treasure. 
Another story has it that Carmack, with his companions, had been fishing, and that, standing beside an old birch-tree, he noticed a sprinkling of gold on the projecting bed-rock. When Carmack dug the first shovelful from beside the birchtree, the result showed much coarse gold. In half an hour, he, "Skookum Jim," and "Takish Charlie" had filled several empty cartridge-cases with the yellow metal. At once Carmack staked Discovery Claim, and No. 1 above for "Skookum Jim," and No. 2 below for "Takish Charlie." Then, taking the gold, they all went up to Fortymile on a spree. They bragged about the gold and celebrated their jamboree; then the whole camp started out, and made for the El Dorado. A pay streak fully 100 feet wide and 4 feet deep yielded rich results, sometimes as much as 100 dollars to a pan. Thus two and a half millions were in sight for Carmack-the fortune he had dreamed of materialized far beyond his expectations. He was said to be a handsome type of frontiersman, standing over six feet, with broad shoulders; he loved travel and changing scenes. "Skookum Jim " and "Takish Charlie," his companions in fortune, were Indians. As far as the first discoverer of gold is concerned, the Yukon statistical volume records that in 1894 Robert Henderson, of Nova Scotia, and a small party arrived in the territory. They prospected for gold along the bars of the Upper Yukon, and rocked out 54.00 dollars in fine gold at the mouth of the Pelly River. Rumour reported gold on the Indian river. Henderson prospected along this stream. No large deposits were found, and Henderson returned to Ogilvie for foodstuffs. The following year saw him working on various creeks. Ho cleaned up 600 dollars' worth on Quartz Creek. Then he prospected Gold Bottom, and came to the conclusion that Gold Bottom flowed into a tributary of the Yukon some distance below Ogilvie. Henderson proceeded down the Yukon to its confluence with the Tron Deg, which is the Indian name for the Klondike, where he found George W. Carmack and his companions, who were fishing for salmon. Henderson announced the discovery he had made, and told Carmack to go and stake on Gold Bottom. A short time afterwards 
Carmack and the two Indians proceeded to Gold Bottom, and staked claims near to where Henderson was working. Henderson advised Carmack to cross the divide and prospect in what is now known as Bonanza Creek. He told Carmack to let him know if good prospects were discovered, and as a result of Henderson's advice, Carmack found the rich deposits on Discovery Claim, and staked them. He took care that the Indians shared in his prosperity by staking " Takish Charlie" No. 2, below, and "Skookum Jim" No. 1, above. Meantime, Bob Henderson, working on Gold Bottom, did not hear of the new strike until all the creek had been staked. This is the authorized statement of the Government, and clearly proves that to Robert Henderson the honour is due for the first discovery of gold. At the present time the Government allow Henderson a pension for being the actual discoverer. But it was George Carmack who played with the millions.

All these stories were circulating in my brain on that lovely sunny day as I skirted Lake Bennett, and proceeded inland to call upon Kate Carmack. The road was dusty; tall, high rushes and weeds formed a wall on either side ; and malignant mosquitoes clustered with maddening persistence on my ankles, evidently enjoying the opportunity afforded by my open-work stockings. There were quite a number of shacks along the road, some of them empty. But by inquiring, I reached at length the home of Kate. It was a small white shack, with weeds growing before the door. I knocked, and several big Siwash dogs rushed out. It was rather a startling experience, but the animals seemed friendly enough. The door was opened by a good-looking young Indian woman, who had a small child toddling beside her. She showed me in, and although she spoke indifferent English, managed to convey the information that Kate would soon be in. Seating myself on a wooden settee, I gazed about. The room was bare and dirty, the furnishings consisting of a broken chair, a rusty stove, and a mirror. My thoughts wandered back to those days when Kate Carmack, wife of the Klondike millionaire, then in her zenith, must have been surrounded by all the luxuries that wealth could procure. The door opened, 
and in walked Fate. She is now a woman of some forty-five, and must have been beautiful in girlhood. Even to-day she is comely, although dressed in ragged cotton. Her straight, thick, black hair was parted over a broad forehead. Her eyes were large, kindly, and dark. She appeared pleased to meet me, and shook hands. In describing events of her early days, Kate recalled that " all the floor was covered with big nuggets." She showed me a faded photograph of herself, very much dressed up, pointed to her belt, entirely composed of large gold nuggets, then to a necklace with a long hanging chain of nuggets. Alas! like the photograph, faded was her glory.

In her queer dialect she said: " That me and my daughter; that my husband; he no see me any more; he live with white wife in Seattle." 'She paused rather sadly, then continued: "My daughter, she say she come see me, but she no come." I felt more than sorry ; it was pathetic to think of this woman, left alone, and returning forsaken to her primitive Indian life. This, then, was Kate, who, with her husband and child, had been fawned upon for gold, who had tasted of the luxury of those early days. Where now are the "friends " of those luckior times?

Many are the stories told of Kate.

When Carmack took her to Seattle, to the huge unfamiliar hotel, Kate could not find her way to her room, so she introduced the way of the forest to the city, and " blazed the trail " by cutting notches in the banisters of the hotel stairway! Needless to explain, this method was not approved of by the hotel management. I asked her if she liked big cities and good dinners. She laughed, and replied : "Me like San Francisco and port wine." Then she pointed to the wall, drawing my attention to a highly coloured lithograph of the King and Queen of England, beside which she had tacked up the pictures of two ferocious-looking Indian chiefs. It now being time for me to leave, I searched my brain for something I could give her as a present. Money seemed rather insulting, remembering that the Government allows Kate a certain amount, whilst her daughter sends occasional help. 
Carmack divorced his Indian wife, and would have taken care of her, but solicitors got hold of her, made ridiculous claims upon Carmack, which so roused his anger that he withdrew and gave her nothing.

Suddenly I remembered I had a large blue silk handkerchief, with a white flowered design. This I turcked into her hand, as I said good-bye. The souvenir apparently delighted her, for she repeated, "Come again, come again."

Time changes all, and Kate's glory is of the past. Nevertheless, a great feeling of inexpressible sadness comes over me as I pass out of that weedy front yard, leaving behind me neglected Kate of the Klondike. 


\section{CHAPTER VII}

\section{ATLIN THE BEAUTIFUL}

THe visitor to Alaska should see Atlin by all means-an ideal spot for the big-game hunter, and within three days' journey of the Nakina District, where moose, mountain sheep, caribou, and various species of bear make their headquarters. In the lakes and rivers fish abound; never is the sportsman disappointed. The entire country round about Atlin is famous for its game, furs, and fish. From Carcross one takes a comfortable steamer through Nares and Tagish Lakes. If fortunate enough to embark on the steamer Tutshi, you will be delighted with this little gem of a boat, a stern-wheeler, drawing a very small amount of water, and burning wood for fuel, as do nearly all the Yukon steamers. It possesses commodious state-rooms, kitchens, and salon, with a beautiful mosaic mantelpiece, referred to jokingly by Mr. Herbert Wheeler (the superintendent of the White Pass and Yukon route) as "a sinful piece of extravagance." Mr. Wheeler is a great character in this section of the world. He sort of "grew up with the country," and having previously hailed from the Emerald Isle, has the true Irish wit and sense of humour. I had the pleasure of paying a call upon him one wet Sunday afternoon. We sat chatting in the salon of one of the lake steamers-not the Tutshi-and wonderful indeed were the stories he related. Waving his hand airily, he expounded, "These boats are simply constructed out of brown paper and faith." I looked up, astounded. The announcement was rather startling, considering I was to embark on one the very next day. "We are rustlers up here," he added. "Atlin Inn was built in thirty days. We had a lot of tourists expected. There was no place to house them, and hotel accommodation had to be found. They therefore put sixty 
men on the job, the inn was finished, and the result satisfactory." Mr. Wheeler has the tact of a diplomatist, and in handling people usually gets his own way, making them believe they have had theirs. Not so, however, with one celebrity who recently visited these shores and failed to find anything quite to her liking. Mr. Wheeler sadly confessed that with the party aforenoted he had enjoyed anything but " a perfect day." It is an unwritten axiom that whatever happens "Mr. Wheeler will see you through."

The next afternoon, however, found me contentedly waiting on the "brown paper and faith" boat bound for Atlin. There had been a thunderstorm, and great purple clouds lined and fringed with glittering silver hung threateningly in the azure sky, as if loath to disperse. The boat was pushed off, all Carcross, including Mr. Wheeler, waving us good-bye. They tell us that for ten or twelve hours all we have to do is to find a "comfy" chair, up in the pilot-house for choice, and absorb the scenery. They assure us that there is more sheer beauty packed into this short journey than can be found in any other place in the world. The green slopes form a palisade of spruce, Jack pines, and other trees, which reflect with unearthly beauty in the placid waters. Promontories push out in the lake, and tiny flower-trimmed islands stand in line picturesquely, as our steamer glides through and past them. Now Jubilee Mountain, with her white cap shimmering in the sunshine; rises thousands of feet above the clouds, as if to beckon to us. One gazes entranced at the dense forests and vast mountain areas, practically a virgin zone. From these lakes, which border British Columbia and Yukon to the Arctic Ocean on the north, to the Hudson Bay on the north-east, one could wander over thousands of miles, encountering neither town nor city. You would see just vast, unlimited space, rarely an Indian settlement, a woodchopper, a trapper, or a " musher," his pack on his back, searching for gold, or a wild animal scampering away frightened at one's approach. As you neared the Arctic, you would come across the Eskimos living in their "igloos" and subsisting upon reindeer and walrus. In these isolated 
realms of mountain grandeur the fashionable silver fox rears her brood, and lynx, wolverine, martin, mink, and ermine lead their natural lives, untroubled save for the machinations of the trapper, who desires their fur for well-to-do denizens of cities. One's imagination wanders over this boundless wild, picturing mentally its possibilities, until recalled to one's immediate environment. A group of us are sitting in the pilot-house, from which is obtained the best view of the ever-changing scenery. I listen as Captain Coghlan relates the fight he observed between a moose and a big brown bear. Sailing along these waters, he saw a bear chasing a moose down the mountain-side. $\mathrm{He}$ stopped the boat in order to watch this unusual combat. The moose sprang into the lake, the bear after him. The moose was wild, and, frightened at the sight of the boat, rushed back to the woods. The bear pursued. Again the moose was obliged to seek the water for protection, and still the bear chased his victim. By that time Captain Coghlan had his rifle ready, and put the moose out of action. When he heard the shot, Bruin retreated to the forest, howling with rage at having been balked of his prey. The Captain feasted on delicious moose steaks for some time after! Every year some distinguished sportsman makes for this paradise for big game. That splendid American, Colonel Roosevelt, has been right through this country, as well as Selous, the great African traveller, who, sadly enough, lost his life in German East Africa, a martyr to the Huns. Both of these mighty hunters had record bags in these northern fastnesses. It is no uncommon thing to draw from the lakes a 40-pound trout; grayling are numerous, and in Atlin Lake mullet, humpbacked Arctic white fish (said to be excellent eating), pickerel, some salmon, and a great variety of trout, fall to rod and line.

As our boat glides along softly, creating the gentlest of ripples, one peers into the forests and along the shore searching for anything which may be of interest. A log-cabin one occasionally passes, set at the water's edge, and roofed by the great boughs of the forest. The occupants are cooking their evening meal on a fire outside, and look comfortably happy. 
Here, perhaps, is a sportsman, delighted to get far away from the haunts of men-and what more glorious for those who love Nature? One's thoughts turn with gratitude to those sturdy, persevering pioneers of 1898 who " blazed the trail " in their search for the yellow metal, and opened up the country for the traveller of to-day who journeys along in modern luxury.

Words are powerless to yield even an idea of the marvellous colours, shadows, and cloud effects of this northern twilight, as we creep peacefully along on the breast of still, mirror-like waters. Midnight passes, and yet no one wants to retire. Stories are told, the captain and his mate are genial hosts. However, as one must sleep, we reluctantly descend. In the morning our boat approaches the Taku landing. Here we leave the boat and take the queerest little train imaginable over the shortest railway journey known $-1 \frac{1}{2}$ miles in length. This train is drawn by what seems like a toy engine. I have never seen a locomotive so quaintly small. Some jocularly proposed to take it home for their children. Another suggested hanging the baby engine on his watch-chain! At any rate, it had a sonorous name- "Duchess," in brass lettering. We called this miniature train the "Duchess of Atlin." Many photos were taken; then we all filed in. It is an open train with canvas top, and conducts us across a narrow neck of land to Atlin Lake.

There are several waters which claim to be the birthplace of the mighty Yukon by way of rival to Summit Lake. Atlin is one of these, as is the Pelly River. Probably the waters from all these sources converge into the Yukon. We now embark on another white boat, on the veritable Atlin Lake. The scene is indeed fairy-like, and as beautiful as any lake in the world. Switzerland has nothing finer, and even that small gem, Lake Lonise in the Rockies, is not a whit more lovely. Iuake Atlin is 90 miles in length; its bluish-grey, snow-spangled mountains rise from the water's edge 5,000 and more feet, and reflect so perfectly into the mirror of the lake that it is almost impossible to define which is the mountain and which its shadow. It arouses a weird sensation, as 
if one were walking along the edge upside down. The peculiar dominating blues, the far-flung broadness, the great expanse of it all, makes Atlin the unique beauty-spot of the world. Switzerland is famed because millions of tourists have eulogized its lakes. But only a few thousand pairs of eyes have ever rejoiced at a view of Atlin. Unfortunately, this wonder of wonders has not been advertised; I rather fancy that Atlin, the lake of shadows, has not the advantage of a Publicity Department. The soft cumulus clouds of summer enhance the charm of it all, and all along the mountain-side Nature has spread her lavish carpets of wild-flowers, dark-blue lupins, dandelions of gold, wild flax, anchusa, blnebells, and a multitude of wild-roses. Picture, first, the banks of flowers; higher, the green slopes of fir, spruce, and pine; and then the blue mountains, with pearly peaks embracing the sky, and all perfectly reflected in this mirror of a lake. Can you imagine it? I go ashore, and across the wooden pier to the Atlin Inn. It seems almost impossible to believe that this large, imposing brown-and-white hotel could have been built in a month. Everyone was obliging and politeno Bolsheviks here! I had a room, with electric light, facing the lake, for 2 dollars a day. The food was good; meals, 1 dollar for breakfast and lunch, dinner 1.50 dollars. The inn is built in rural shooting-box style, and in the evening, seated in the big armchairs in the spruce-lined livingroom, before a roaring log fire, one felt well content with the surroundings. The morning view from my window was superb. Mount Minto guards the entrance, a giant in spotless white ; the Cathedral Mountain shadowy and mystic; the Llewellyn Glacier, a frozen sea, banked with snow, awesome in its grandeur, and over all intense silences, spaces of measureless blue.

Skagway is the port for Atlin; all points of the Atlin district are connected by rail and steamboat service with the American port, which also acts in a like capacity for the Yukon. The people of Atlin rather resent having no port of their own. Indeed, several petitions from the citizens have been sent to the Canadian Government, without any particu- 
lar result. During the winter a stage runs regularly between Carcross and Atlin. The journey is made principally on the ice, and dog-teams carry the mail between these points. Atlin had its gold stampede in 1898, the discoveries having been made by Miller and McLaren on Pine Creek in January of that year. The gold production of Atlin totalled in 1898 75,000 dollars, but in the following year it amounted to 800,000 dollars. From 1800 to 1907 inclusive, the average for those years is represented by 431,000 dollars, and in 1909 it was 200,000 dollars. Placer gold attracted the first rush into the district in 1898, but placer gold is but a small matter compared with the gold in quartz, the silver and lead, the molybdenum, and the magnesite which abound in the Atlin district. The representative local authorities complain bitterly that owing to the cost of transportation, which is a vital factor in the development of the country, these mines cannot be worked. For thirteen years the citizens have been pressing the Government to assist in establishing a route to the coast. If the waggon road were only extended from O'Donnell Creek to the British Columbia boundary-line on the Taku River-a distance of only 60 miles-a great impetus would be afforded to local development. The enterprising American Government is building a waggon road from the sea to this boundary-line, and progressive Juneau men are arranging excursion parties from Juneau up the Taku River into British Columbia, to illustrate the resources both in the way of agricultural lands and mining prospects. The general impression, whether right or wrong, is that the Government, not wishing to spend money in these parts, was guided by adverse opinion regarding the feasibility of this route, which practical men who really know declare to be entirely unfounded. This route, it is estimated, could be opened for about 60,000 dollars, and the Atlin people consider that the Government should help them to open up the country, and facilitate the development of the great mining wealth of the district. This is even more desirable, remembering that the British Government is pressing for a greater output of gold, copper, and iron. Archbishop du Vernet is one of many 


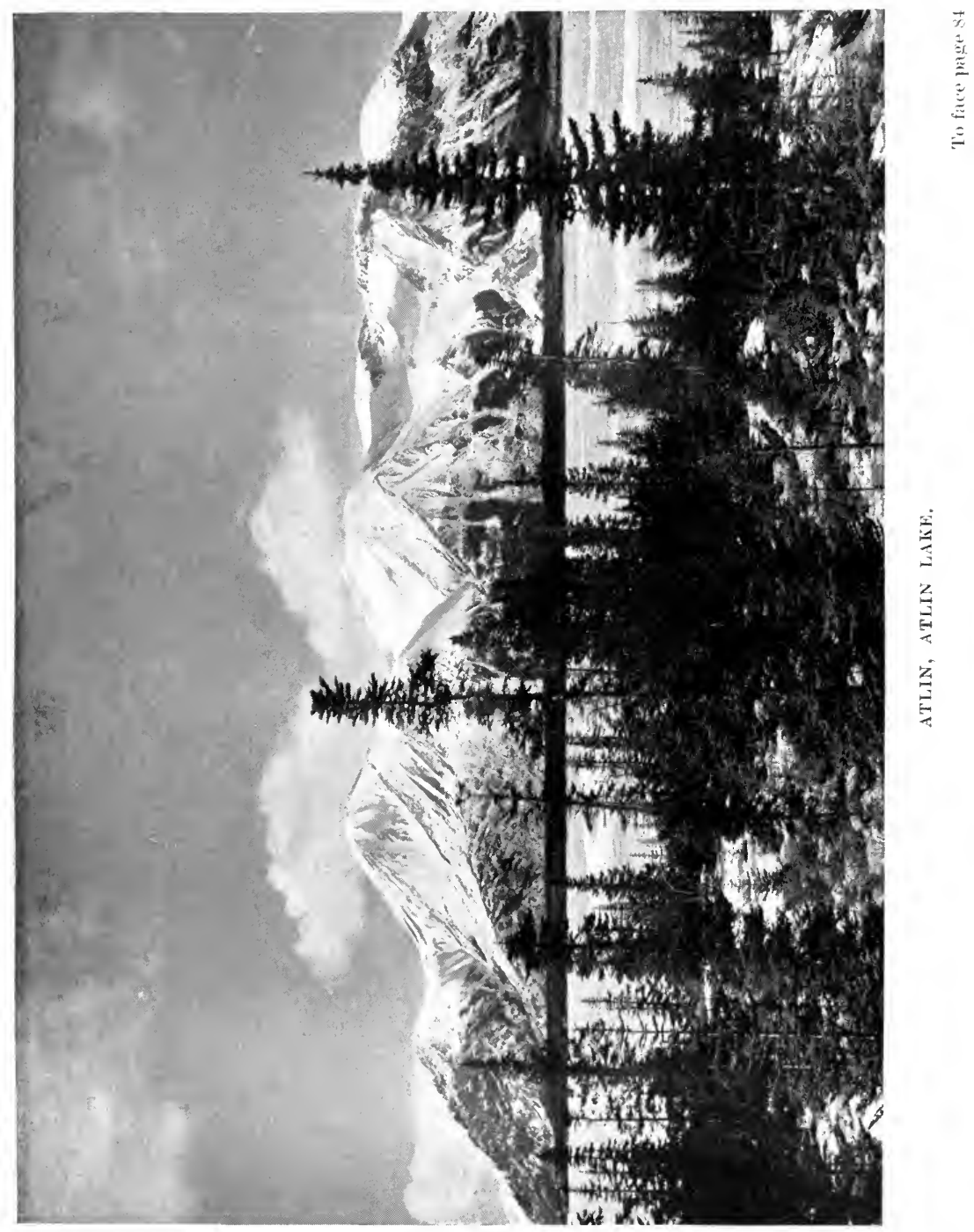



who ardently advocate the advancement of this all-Canadian route into Atlin. The Atlin people are optimists, and patriotic to a man; they have faith in their country, and are hopeful that the Government will give them help to export the rich deposits now reposing in the bosom of Mother Earth. Everyone in this Northland is cheerful, glad to meet you and to talk with you. They will go out of their way to render you a service. There is no need of an introduction; they greet you as one of the great family of humanity, and I do hope that when the tourists arrive in greater numbers they will not take advantage of these kind hearts. May the people cling to their old ideals, and not discover the cloven hoof amongst those who will eventually invade this lovely country. I am rather surprised to find in this part of the world-through Alaska, Yukon, and now in the farthest North of British Columbia-that tourists have no reason to grumble at the provision made for their comfort. In fact, when you realize the remoteness, and the miles which necessities must travel, the expensive haulage and freight, it certainly is wonderful that they can afford you as much comfort as they do. To me, whose home is in London, the simple kiñnness of the Northerners has been a series of pleasant revelations. For example, I wanted to take a drive about Atlin, and not knowing anything about their prices, I arranged with the youthful driver to take a 2-dollar drive. My time was limited, as we were all going on the lake in the afternoon. The youth conveyed me in his car all over the country, for many miles more than I was entitled to, and when I offered him a larger fare he shook his head, and would only accept the 2 dollars, as agreed. At an hotel in this hospitable region I stayed for four days, and the landlady refused to accept payment, saying I had done her good; she was glad to have had me. I looked at her, astonished, thinking my ears must have deceived me. All my life I have travelled in every clime and zone, but this was my first experience of a landlady refusing to accept her due. Naturally, I could not permit this generous woman to board me gratis, and I put the sum she was entitled to into 
her pocket. Verily, there is a deal of gotd in the hearts of humanity.

In Atlin I lost my one and only hatpin-such a nuisance, especially when on a windy lake - and had left my luggage with its reserve supply in Carcross. I went into a shop for another. The proprietress did not sell hatpins, but at once offered me two of her own. I took one, but she would not accept payment, and I was obliged to leave the money on a table, asking her to put it in the poor-box. It is not often you meet such people. There are no real poor here. Everyone works; all help each other; all can earn a living. The climate of Atlin is marvellously healthy and invigorating, as the complexion of the children affirms. There is tonic in the air, the elevation being about 2,200 feet above sea-level. There is at present no doctor in Atlin. I visited St. Andrew's Hospital-being a Red Cross war-worker, hospitals interest me. This is the original of the Presbyterian Mission Hospitals, of which many, fortunately, are now established all over Northern Canada. It owes its inception to the efforts of that wonderful man, Dr. Pringle, and is presided over by Matron Ames, a woman who is certainly accomplishing splendid Christian work. With the help of one assistant, she keeps the hospital as clean as the deck of a battleship. The matron had just finished with a dangerous pneumonia case, but at the time of my visit the hospital had not a single patient. I was shown over the different wards, one of which was given by Mrs. Charlotte McDonald, of Toronto. Matron Ames told me of her work in those early days of 1898, when she was a young volunteer nurse, when, with several others, she gave her services to Dr. Pringle.

Dr. Pringle is a real practical Christian. He left his church, where he was most comfortably installed, and came out here to do good work during the mad rush for gold. In those uncontrolled days every house was a bar, drunkards were as numerous as flies, and gambling-dens flourished. Dr. Pringle used his influence with this wild, reckless element. His was the fine gift of perseverance and patience. He used to preach to some 10,000 people, and his great work 
is a monument for the betterment of humanity. In the mining camps of 1898 men fell ill as a result of their intense hardships. The cold was cruel-40 to 60 below zero in winter-their food was poor in quality and quantity; they lived mainly on beans and sour flour. There were no vegetables, and scurvy attacked them in thousands. Matron Ames described to me how in those days the Mission under Dr. Pringle was a single tent hospital. In that dreadful cold and snow the nurses would sit wrapped up in heavy coats trying hard to keep warm, waiting for " cases." Dr. Pringle often found men almost dying in the camps, and he would bring them in on his back, staggering through the snow, endeavouring to save lives as well as souls. After a while he managed to get a dog-team to help bring in the sick. There were no pillows or beds. The men would put their packs under their head, and lay down to die; often the dead would rest alongside the living. Yet under these conditions Dr. Pringle and his helpers struggled on to relieve pain and stave off death. Finally, Dr. Pringle went to the bank, begged and prayed until he got them interested, then, with borrowed money, built a wooden shack, where at least shelter could be secured from blinding snow-storms and freezing Arctic winds. With the shack at their command, the nurses were encouraged. They nailed up wooden bunks, made pillows and beds of packing-case contents, mixed with hay and pine needles, and made good use of some sheets that were charitably given them. From this humble beginning the Presbyterian Missions originated, and have proved a blessing to the people ever since.

This tiny town of Atlin, with its one broad road and two or three branch thoroughfares, is extremely patriotic, and, for its size, has raised more funds for the Red Cross than most communities; 17,000 dollars is a fine example of generosity in a case where the entire population consists of some 300 souls.

Another circumstance about Atlin which struck me as commendable is that every returned soldier who has fought for his country is given, as a mark of respect and loyal apprecia- 
tion, a fine gold watch and chain, fashioned from gold from the near-by mines.

The Union Jack floats gaily in the sunshine against a background of snow mountains and indigo sky. Certainly the old flag guards strange lands and peoples-protection, justice, and law are its emblems. In passing along the streets I remarked a queer fire-alarm. It was a triangular piece of iron suspended from a tall pole. Attached to a rope was an iron striker, and when there is a fire, a relentless enemy in a wooden-built town, they strike the irons together to summon help. It being the first time I had encountered this primitive fire-call, I stood regarding it. Opposite was the gaol, a small frame house. The chief constable came out and kindly explained the procedure in case of fire. His name is Robert Webster. A typical specimen of these hardy Northmen, Webster stands over 6 feet, gaunt, shy, bronzed, with a genial expression. Recently demobilized, he went out in Captain George Black's contingent. Captain Black, by the way, was Governor of the Yukon. Webster afterwards enlisted in the P.P.C.I.I., and had fought in most of the great battles, where the men of the Princess Pat's were mowed down like chaff before the Hun advances. I am sure that Webster must have been over age-limit, but in this faraway land that, seemingly, did not matter. Men mushed down from the Arctic Circle to fight for the Empire. Men most obviously over sixty would swear without flinching that their years were under forty, in order to be taken into the army. They vowed to have a hand in the fight for the rights of man. Constable Webster was a man of this class, good material for empire-making; his words were few, his actions spoke. Most of his regiment lay asleep in Flanders, for, as is well known, there were not many survivors of the famous and popular Princess Pat's. All the world loves a romance, and I was interested to hear this tall, shy ex-soldier of the Northlands approve that Princess Pat, as he called her, had been firm and self-reliant enough to marry the man of her choice. Constable Webster showed me his gold watch and chain. He opened the case, and I read, "Presented to 
Robert Webster, P.P.C.L.I., by Atlin and Discovery friends as a mark of esteem for his services rendered in the Great War." It would have been a fine idea if some other towns had followed the example of Atlin.

Continuing my stroll, from the gaol I visited the Court House, the Masonic Temple, the Episcopalian church, and the Royal Hotel, owned by Mr. Shultz, who has amassed considerable wealth in these parts. I passed a fine jewellery shop, which displayed ornaments made of the native gold, a much larger and finer selection than one would have expected, the cut glass especially. When I inquired who purchased these expensive goods, they told me the miners who live out on the creeks. When they marry, their pals, who make very good money, give them fine wedding-presents. Everyone said, "Oh, you must see our soda springs," and as I was out to see things, I went. From out of the ground wells up a bubbling stream of crystal water, very palatable and refreshing. Amongst the minerals in the water are slight traces of carbonic acid, potassium, soda, lime, and magnesia. Some of the residents dream of the days when people from afar will arrive to "take the waters" of this health-giving stream, which they predict will be as famous as Carlsbad. From here I passed through the Indian village on the other side of Atlin; it consisted of shacks and tents, the Indians living and carrying on their housekeeping outside. Dogs and children sprawled at will, a young girl was plaiting baskets, some squaws were currying skins, and half a dozen "braves" sat in a circle idly smoking. There appeared little enterprise or movement in this somnolent native settlement.

In walking about Atlin, with its tiny log homes, cemented in every crack to keep out the winter cold, you will meet the burly " huskies," or malamute dogs. They eye you sleepily as they lie in the sunshine, or occasionally they will get up and brush against you with a friendly wag of the tail. These huskies amused me greatly, as my only acquaintance hitherto with these interesting species had been through the writings of Robert Service, Rex Beach, and Jack Iondon. 
These dogs vary in colour, mostly tawny with black mixtures, and are of inestimable value to this Northland. What the camel is to Egypt, the llama to the Andes, the elephant to India, so are the huskies to Alaska and the Yukon. The people are very fond of their dogs; a good dog fetches 75 dollars to 100 dollars. The dogs are harnessed into small high-backed sleighs, most comfortable when you sit wrapped up in woollens and furs, only a part of your face exposed. Then off you go for a long ride. Sometimes the dogs will run away, and you tumble into the snow; but after their frolic they will return to look for you. They are highly intelligent, and have a keen sense of smell. Many a man's life has been saved by the huskies. He may have fallen and been buried in the snow, but the dog will ferret him out, infuse warmth into his body, lick the frozen face into life, if possible. In winter, at election-time, someone goes out with a dog-team to gather in the votes from far-away points of the territory, often mushing as much as 350 miles to bring in seventeen or twenty votes. The Atlinites know all the dogs by name, and will speak to them as they pass: "Hello, 'Buster,' 'Prince,' or 'Rex.', There is a noted dog, called Bowser, who is a famous fisherman. $\mathrm{He}$ will patiently wait beside a narrow stream, and when a fish floats along Bowser is so expert that by a dexterous flip of his paw he will hit a fish, throw it up on a bank, and devour it at his leisure. Thus Bowser earns his living. My attention was attracted to many fine motor-cars with full complements of Indian familes. Upon inquiring, I was informed that many of the Indians about Atlin are wealthy. They have made money washing out gold from the creeks, and their first extravagance is a motor-car. I motored out to the mines at Discovery, a small town of the crudest, ugliest conception. The one street follows the Pine Creek, which, down in the valley, rushes furiously along. Most of the ramshackle, primitive buildings were formerly bars, but at present prohibition holds sway. I was amused to see a dreadful-looking establishment, from which depended a sign-board, "Balmoral." A memory of Scotland, no doubt, its dilapidated 
appearance suggested anything but a resemblance to Queen Victoria's favourite seat. Most of the houses were of the false-front order, camouflaged as two stories, where only one story existed. Here, also, a small ragged British flag flutters in the breeze. At one so-called hotel the sign was upside down. In the golden days of 1898 everything boomed at Discovery. Gold in heaps could be obtained by simply washing and sluicing pans. The little log-cabin still stands near which the pioneers first discovered the magnetic gold; and thousands were later attracted hither. In those green hills beyond are mines of silver, gold, and copper. The scenic surroundings are ever beautiful. A foaming mountain torrent swirls over the rocks below; the air blows freshly off the snow mountains; wild-flowers of every colour clothe the lofty banks.

Discovery Mine is worked by hydraulic power; great jets of water, over which rainbows played, were washing the earth down. Looking at the hill from which the soil was being removed, one would never suppose that the dullcoloured earth produced both nuggets and gold-dust. The men standing in the mud and wet are shovelling the pay dirt into wooden cars on wheels. These are drawn by means of a cable, run by a water-wheel, over to the long row of sluiceboxes into which the gravel is dumped. Then the running water, carried through pipes, continually washes and carries away the gravel dirt, rushes it over small ridges, called riffles, that catch and retain the gold, the metal being the heavier. About once a month there is a general "clean up "; the water is turned off and the gold removed from the riffles. I motored also to the Spruce Creek Mine, which appears to have miles of sluices, and is a rich property situated in a canyon, with another mountain stream which furnishes the power to work the mines. About this location are many mines, some being worked, others deserted. Remnants of shacks and broken windlasses are reminiscent of the pioneer days. Men become fascinated with this wild, free life. After all, they are their own masters, and there is always the gambler's hope that at añy moment they may 
have the luck to find a rich pocket. And there are many who, having found success, will not change their primitive shacks for the luxury and excitement of towns. One example in particular was pointed out to me. The miner has acquired immense wealth, and formerly lived with his dogs in a tiny shack. He has removed from the shack to a humble, well-built log-cabin alongside his former home. $\mathrm{He}$ rarely goes away, and says he is more contented and happy in his log-cabin with his dogs than he would be in the most luxurious suite in the highest skyscraper of New York or 'Frisco. Men with fortunes of 80,000 dollars and 100,000 dollars you will find living in the creeks in shacks and cabins. Some of these shacks present a weird appearance. To render them warmer in winter, they are covered with a black tarred cloth and studded with large-headed silver nails, this imparting rather a funereal touch. It was more lovely than any words of mine could portray, this motoring back along the creek-bound roads, enjoying the exhilarating crispness of the pure mountain air.

It was 10.30 p.m. when I returned to Atlin Inn. A group of my fellow-travellers were arranged in armchairs on the verandah, waiting for the sun to go down. I fear they will have to sit up all night. Being tired myself, I went to my room, too sleepy to admire anything more in the way of scenery, remembering that the night before $I$ had tried to put the sun to bed, but failed! I took one more look at the lake as I pulled down the blind to darken the room. It seemed ridiculous to go to bed; out there on the lake the sun was shining brightly. I began to wonder if I were in my right mind. I had not to wonder long before sleep closed my eyes. The next day I met Mr. L. C. Read, one of the most popular characters of this region, one who knows every inch of the country, and can tell you reams about glaciers, the haunts of the big game, the waters from which to coax the finest fish; every flower he can call by name. $\mathrm{He}$ is a musician, a wonderful photographer, and took some of my Atlin views. Mr. Read came originally from the New England States, and wears his seventy odd years with the 
zest of a boy. His stories and information of the country are most valuable, and he is coming with us on the steamer to go around the lake and to the Llewellyn Glacier. This afternoon the Atlin Lake, with its visions of shadows and perfect reflections, seems more faithfully depicted than ever, perhaps because we are on the lake; our boat seems to be progressing upside down! The northern part of this 90mile lake is in Yukon territory. Looking backward, stately Mount Minto, 7,300 feet high, stands in commanding attitude, gazing down upon its neighbour, Jubilee Mountain. From this sapphire, jade, and purple lake rises the Cathedral Mountain, where, in winter, the snow piles itself in some places more than a hundred feet deep. The boat begins this most enchanting tour. We pass the Indian village, through Torres Inlet, and around Goat Island and Copper Mountain. On the green-fringed shores a log-hut is occasionally passed; usually someone is fishing from the shore. The huts are mostly concealed by a natural barrier of trees; a dog will howl or bark-the malamutes prefer to howl. The old chief of Taku is camping on a point projecting into the lake, and we glide very close alongside. The steam from the Indian cooking-pots rises into thin ascending spirals. The dignitary sits near by, smoking a pipe, while his squaw and a papoose are walking amidst the spruces. Now and again the squaw will bend down and pick up something, probably a herb for medicinal purposes. This scene of repose and rural beauty takes one back to the old days, before gold was found, and when Indians and animals alone inhabited these boundless spaces. The mountains rise higher from the lake; their bleak sides of 5,000 and 6,000 feet confront us in towering grandeur. Huge waterfalls tumble from the rarefied heights; small avalanches of snow slide down from the corrugated walls, with a dull, resonant thud. Above, near the crests of the peaks, are long, protruding snow cornices, which the sun has helped to dislodge and melt. Now the sun filters through the mass; it is as if light were shining through alabaster. At times these ethereal-like cornices break off and come thundering down. We now approach 
Llewellyn Glacier, which is a continuation of the tongue of the great Taku Glacier, some 90 miles to the south, near Juneau. As we steam towards Llewellyn the whole scene is of the Arctic, even to the white gulls hovering about. This glacier is 4 miles wide, banked with innumerable piles of gigantic ice-blocks. Great snow-mountains and cruel-looking jagged peaks are custodians of this frozen sea. The air becomes very cold as the icy wind strikes our faces. This is a live glacier, moving constantly, ever so slowly. It corresponds to those of Switzerland, the movement of which is 20 to 27 inches in twenty-four hours, as compared with those of Greenland, where the glaciers shift from 24 to 64 feet in twenty-four hours. 'This great glacier is truly wonderful, awesome in its grandeur, splendid to behold. But, to my mind, Taku is more beautiful.

We were glad to turn our backs on that fierce Arctic wind, as the steamer silently glided through narrow canyons, some of which were decorated by as many as eight snowy, leaping torrents. Again the lake assumed many a shade of colour. The jade-clad hills and sheer black walls of the mountains form an unusual panorama of beauty. What we have seen is certainly a marvel of God's work in Nature, and is indeed a heavenly lake. If chance should ever offer, Atlin Lake should be seen by everyone blessed with the opportunity. 


\section{CHAPTER VIII}

MILES CANYON, WHITE HORSE, AND YUKON RIVER

IT was a warm, sunny day in June, just like a summer's day at home, when the train pushed out of Carcross headed northward. The surroundings of Nature are still beautiful, but one becomes-yes, let it be admitted!-surfeited with scenery, and unless the environment partake of the phenomenal, a certain indifference and lack of intense interest are inevitable. The White Pass and Yukon train puffs alongside the Watson River; then Lewis Lake is reached. This also has its history. Engineering experts almost completely drained the lake when arranging to lower its level some 15 feet. They dug a channel through the sandy hills, and when the water ran its unaccustomed course nothing could arrest its furious passage. It quickly cut a vast canyon for its bed, and lowered the lake 70 feet! Fortunately, no damage was done, there having been no habitation along the route. Fields rich with dark purple, sweet-smelling lupins perfume the air. I am sitting in the open, on the platform of the observation car, and now Miles Canyon-named after General Miles-comes into view. The train slows down considerably at this point, and as, from its brim, I look down into the deep, world-famed gorge, my thoughts go back to those days of 1898. I see far below remains of what I should name the "Heartbreak Trail." Do the ghosts of the thousands who made up the enormous gold-seeking army-and many ended their days in these environs, especially in the White Horse Rapids, just below-do they visit the spot on moonlight night? one wonders. No record has been kept of those who essayed, in their frail canoes, rafts, or anything that would float, to shoot these dangerous, seething rapids, as mad in their career as the mob of adventurers who tried 
to negotiate them. A story is told of a man who tied himself to the bottom of his boat and crossed the rapids in safety. But hundreds of men, with desperation written on their faces, saw their outfit and everything they possessed caught up by the rapids, whirled into the swift, boiling caldron, and disappear. Many who had hardened their nerve, fought and conquered the White Pass and other superhuman difficulties, looked with blanched faces at this seething barrier. No wonder there were some who likened it to a trip through Hell itself! Often the whisky-bottle would be handed round in order to give the Argonauts false courage to enter the whirlpool. After a time the North-West Mounted Police prohibited the adventure, and no one was allowed to go through the rapids without a pilot. These waters inspired such fear that they became the last resource of the disappointed tenderfoot. Many a man committed suicide rather than face further hardships. With a shudder of relief, one murmurs what a blessing it is that one can now travel on this route in comfort and safety, merely looking down upon these surging waters, which seem ever hungry for lives. A few more curves are passed, and one has arrived at White Horse, the northern terminus of the White Pass and Yukon Railway.

White Horse is situated on the west bank of the Lewes, with a tableland behind it, on Fiftymile River, or, as it is called by some, the Upper Yukon. There is not much to be seen here-in fact, from the train windows the whole town, with its wide streets and several stores, is spread out before you. That splendid body of men, the North-West Mounted Police, have picturesque barracks, higher up in the town, built largely of logs, with little flower-gardens in front, everything looking ship-shape and comfortable. There are several good shops for furs and curios, and if you desire to purchase silver foxes, Drurys have a fine selection. Crossfoxes and wolverine were most attractive. A silver fox, even in the home district of foxes, natural, not dressed for the market, will cost from 400 dollars upward. You should get an excellent specimen for 500 dollars-large, dark, with deep silky fur. 
White Horse is popular, as it is about the only place where unlimited whisky is, or was, obtainable. In one of the shops I visited they were still talking of the Midnight Sun Festival; they had scarcely then recovered from its effects! We went into an hotel where were queer little private boxes, curtained off with soiled, faded red draperies. It had been one of the resorts of the early days when gold-dust was literally thrown about. The proprietor who served us had the face of the Sphinx. He began to narrate to us chapters from his history. I forget the exact number of times he said he had been married, but it was a good few, at any rate! He had, so he told us, braved all the hardships of the early days.

We dined at a small restaurant, the only one in town, where the food was most indifferent. Then we motored to the rapids, the celebrated White Horse mosquitoes interviewing us in the meantime.

Now, I have met many members of the mosquito family. In my 27,000 miles' trip in Africa there were many a virulent species of these pests, and I award the palm for vile poisoners to those indigenous to the West Coast of Africa, especially in the Cameroons and Nigeria. They transmit to you all kinds of dread diseases, and each bite will assume the proportions of a five-shilling piece! Out there, the simplest and most effective antidote is to cut fresh limes and rub the juice well in. This new army of Yukon pests I am just beginning to become familiar with. They certainly can set up an irritation all right! The Indians have a legend as to the birth or origin of the mosquito. According to them, a terrible giant, a man-eater, walked the earth. One of his delights was to partake of human blood, which to him was an elixir. In those ancient days there appeared a most interesting young man, whose hobby it was to kill giants. Chacun à son goût ! A combat eventually was arranged between these two, the giant's son being present. When the giant had gone to fetch his knife, the young man inquired of the son, "Tell me how I can kill your father, or I'll kill you." The frightened boy replied, "Shoot him on his instep ; his heart is there." Soon the giant returned, rushing at the young man and brandish- 
ing a huge knife. But this ágile David pointed an arrow at his Goliath's foot, and the arrow got home. The giant, as he died, threatened, "Though you burn me, I'll bite you." Whereupon the young man burned the giant's body and threw the ashes up into the air, remarking sarcastically, " Bite me, will you?" Then each particle of ashes in falling became a mosquito, and so the giant kept his word-he's been biting ever since. Thus declare the Alaskan Indians.

White Horse is the centre of some very rich copper-mines, about 8 miles distant. Silver in large quantities has been discovered, as well as extensive coal-fields, which only lack the coming of a capitalist who would harness the rapids and supply the power to open up these valuable lodes. As a cheechako I should say that, unless called here for business, there is nothing at White Horse to attract visitors. A mosquito-veil should be added to one's kit, so the sourdoughs advise. These are large, voluminous chiffon or mesh affairs, which go over one's hat and hang down to the shoulders or waist, in order to protect the hands. It was strange to see men wearing them. They seemed at first to be walking around with their heads in a cage! Nearly every wood-chopper, musher, trapper, or whatever he is, protects himself with an effective mosquito-net. Men have been known to have been driven to madness in the isolated forests by these virulent torments. You may buy the nets in all colours, to suit your taste or complexion, but the men who work prefer black.

I now embark on the Selkirk for Dawson, 760 miles downstream. Distance seems nothing to the mighty Yukon. As we proceed with the tide, the boat should arrive in forty hours, barring mud-banks and a few other hindrances to navigation. The Selkirk is old-fashioned, but comfortable. She is only 500 tons, and draws 4 or 5 feet of water. Cabins are large and very clean, food good, and every attention from all employees. To my great satisfaction, several of my newfound travelling friends were on board-Senator and Mrs. Heckman, Mr. Steffin, and Miss Jackson-an enjoyable party. At 8 p.m. we sailed down the Yukon, now a presentable river, 
having emerged from her dirty icy swaddling-clothes of the Summit Lake, and now arrayed for the novice in summer clothes of blue. The Yukon just now vies in hue with the sky. The colours and glow on the distant snow-mountains, the great brown clay cliffs, 300 feet in height, with forests of bright green spruce, are reflected in the Yukon's azure depths. Great bastion projections of rock block the way, and you wonder how the boat can pass. It calls for an able navigator to negotiate this ever-changing Yukon. Mudislands form in a very short time, and the swift current, resembling the Nile, is ever an enemy to the captain; the waters wind about like a serpent. It is no uncommon thing to run upon a mud-bank and stick. We have just experienced that unhappy catastrophe. It is endless work "picking up a dead man," as the nautical term goes; the unwinding of cables, yards and yards, seemingly inexhaustible; the attaching of it to a solid foundation-this time a rock. Then the work of rewinding the cables, pulling and hauling until the boat is free. We have had a wait of five hours, yet they tell us we are lucky: we might have been held up all night! But there is no night in this Northland. We sat chatting in the prow of the boat, watching the diminishing rays of the sun and the heavenly glow, which neither pen nor brush could depict. Purple thunder-clouds loom up, and the golden sun irradiates the green mountains, and the snowy peaks take on the hue of the blush rose. Gradually the twilight deepens, full of mysterious beauty, and we remain watching each colour effect, entranced with the unearthly loveliness of it all. Now we pull up alongside of a huge wood pile of a hundred cords of logs, for the Selkirk, ever hungry for wood fuel, needs power to propel her up to Dawson. These spruce logs are neatly piled; the wood is split from trees running from 4 to 6 inches in diameter, and is brought on board in wheelbarrows. There are no woodchoppers near-in fact, so far, one has seen very little life along the shores. We see dotted about many holes, homes of the beaver and musk-rat, and island after island in deepest solitude, untrodden by man. The game here must revel 
unmolested. One wonders how many thousands of years Nature must have waited here for the birth of towns, or was it millions of years ago, inhabited by races extinct to-day? Maybe this great land, in all its vastness, cradled people when the Incas ruled South America, when Chinese civilization was at its height, and Egyptians travelled over miles of African deserts to lay votive offerings at the altar of the Sphinx. Who, after all, can bear witness to the coming and going of races since the birth of the world?

To return to matters mundane, an excellent supper of cold meats, sardines, salad, cheese, and sweets, is served on the Selkirk up to 11.30 at night; therefore, when one becomes weary with dreams and scenic effects it is pleasant to go below and fortify the inner person. Very jolly are we at this meal ; there is no reserve: we are like a large happy family. From the old-timers who have lived in the Yukon for years we can glean much curious knowledge, and they on their part are glad to hear news of the " outside." Senator Heckman tells of the time when Ketchikan was simply an Indian village : he helped to establish the enormous canneries there; from Mr. Steffin we have the genuine prices for pelts, facts as to the ways of the fur-bearing animals, for he is continually buying thousands of skins. Those who know not the land listen in wonderment at the tales of those early days. One lady at the table said she had " hiked" on hands and knees most of the time over the White Pass and frozen lakes; explaining that this queer method of locomotion was due to the fact that she was not properly shod, and the snow accumulated on her boots and prevented her walking. "If there were only more ways of transportation!" sighs an old sourdough. "Why, the Yukon territory contains 192,000 square miles, and more than half the area is habitable! It's the last great frontier of Canada, and it's a real paradise compared with other parts of the world, where millions of people live-and prosper," he wound up snappishly. "But you have transportation for only about four months of the year, and Yukon, Northern Alberta, and also Northern British Columbia, are practically without a railway," ventured to 
suggest a mere cheechako. "That's just it," replied our sourdough friend. "If the Canadian Government would open up the Yukon with electric railways-we have the power in a hundred streams-it could be cheaply done. Our mineral resources have not been scratched as yet. Not only resources in gold, but practically in all kinds of minerals. Yukon can raise turnips weighing from 25 to 44 pounds apiece, and other food-stuffs. Canadians should insist upon these railways, for their own benefit. All that the Yukon wants is transportation, in order that she can send more wealth direct, and let the families from the overcrowded cities pour into the territory. It can support them." Another patriotic Yukonite spoke up, saying: "We sent 600 men to the Great War. The Canadian Army sent the Hun on the run right enough. Look at our subscription to the Victory Loan, although such a few of us! Why, last November, Dawson subscribed 318,000 dollars in cash, and got twenty-one crowns on her Victory Flag. Canada had some returns in municipal orders and war purchases, but Yukon received nothing. Now Yukon wants a railway, and should have it. Why must all our business and exports go through the American port at Skagway?" This discussion was very interesting, and one could quite understand the logic underlying it all. Coming into a country, one has no idea of the desires and feelings of a people, but if one is an acute observer it is not long before one digests its problems and gets to know the spirit of the inhabitants. Although there is no night in this part of the world, Nature, however, calls a halt when one is bodily exhausted. I glanced at the clock; it was 1 a.m. In my absorption I had lost count of time, and made my way up on deck. Again I am housed in the "Texas," the top deck, and as I pick my way along I pause to look at the quiet majesty of night on the Yukon. The silent islands are bathed in mellowed silver. We are passing ramparts of reddish rock, the tops of which resemble stately castles with innumerable castellated towers. Terrace after terrace surround these moated castles. The soft air is sweetened with fir balsam and wild-lupins. Somewhere in 
the distance I catch the tinkle of glacial waterfalls, while the midnight sky is clotted with clouds fringed with violet, rose, and gold. Regretfully, I shut out the picture, and enter my comfortable cabin. There are two small windows, not portholes, curtained in dainty white, a small white bed, a willow chair, a camp stool, and washstand with mirror. It is electrically lighted, but I have no need for that. Floating down the Yukon, fanned by the perfumed air, how I wish all the world could see and enjoy it with me! Am I, too, under the "spell of the Yukon"? Half-dreaming, Robert W. Service's lines come to my mind:

The summer, no sweeter was ever;

The sunshiny woods all athrill;

The grayling aleap in the river,

The bighorn asleep on the hill.

The strong life that never knows harness;

The Wilds where the caribou call;

The freshness, the freedom, the farness,

0 God! how I'm stuck on it all.

Next morning, after delicious rest, I am awakened by the steward bringing a cup of coffee and an orange. The windows were wide open all night, and my sleep had been most refreshing. The boat is slowing down. Immediately I get up to see what is happening. The Selkirk has pulled up alongside another wood pile for her breakfast of logs. She burns one cord of wood an hour, and it costs 7 dollars to 8 dollars a cord.

Sheltered in the spruce woods is a log-cabin-a squaw comes out with her papoose slung on her back-and there are some salmon-nets stretched along the shore. The sun is making itself felt. One disagreeable feature of these stoppages at the wood piles is that we are at the mercy of King Mosquito, who loses no time in getting busy. Everyone adjusts the veil and defies him, but, alas! one can't very well veil one's ankles. For there-mixed anatomical metaphor !-is the Achilles heel of the visitor.

Miss Jackson and I went on shore, watched the purser with his notched 10-foot pole measuring the wood he had taken, and had a curious interview with the squaw and 
papoose. We found lovely wild-flowers in the forest, and brought a quantity on board for the tables. We passed Lake Le Barge in the night. It was named after Michael Le Barge of Montreal, who came to the Yukon with the exploring members of the Western Union Telegraph Co. I was sorry to have missed it, because of its association in my mind with "The Cremation of Sam McGee"-Service's humorous poem. I don't know if I expected to see the ruins of the "cre-ma-tor-eum" or the ghost of Sam. However, 'tis my misfortune that I shall encounter neither, now. This part of the Yukon reminds me of a precocious youth, a buoyant, tortuous, reckless stream. It leads you on, playfully, like a schoolboy, through its palisades of greenery and rock. It is like a maze, like the spirit of mischief, desiring to fool and confuse you, Now it is a lake enclosed by steep formations of granite. Then the imp of the river will, when you decide in your mind that there is no outlet, laughingly lead you around a promontory, and lo! you are again in spacious waters. As the boat swings from side to side, you next find yourself in a yawning canyon with perpendicular walls. Such are the mischievous pranks of the imp of the Yukon. We halt at Cassiar Bar, near the Teslin River, where, in the eighties, gold was discovered. It is a small deserted settlement of three or four log-cabins shrouded by Jack Pine and spruce-trees. We throw off a mail-bag; the dogs howl. How lonely it must be to pass one's life here, particularly in winter, when the Yukon is one long pathway of solid ice from the White Pass to the Bering Sea, 2,200 miles. Having passed Big Salmon and Little Salmon, the Eagle's Nest Rock, said to be 1,500 feet high, comes into view. There are several caves in the rock; whenever there appears enough space for flowers, the flame-coloured fire-weed decorates the landscape, contrasting charmingly with the emerald spruce and fir. We sail through narrow gorges which are little more than the width of our boat: we almost graze its sides just when we expect to see our boat crash against impregnable walls.

We pass Tantalus Butte, where enormous lodes of coal 
await development-a coal-belt which could supply all the Yukon. George Carmack is credited with its discovery, and the settlement across the river is named after him. There appears to be no limit to mining possibilities in this country, if only transportation were available. Now the Yukon narrows to 150 yards. Great bastions of stone loom up as we begin to approach Five Finger Rapids, the most thrilling experience of the trip. Slowly we move through frowning barriers of sheer rock 50 feet in height. It is early twilight and the dinner-hour, but no one wants food when there is this austere grandeur of Nature to gaze upon. The Yukon is surging and struggling in its mad rush to force a way through. An enormously high, solid island of stone, on the top of which the green spruce waves, challenges further advance. On every side the frowning, grim mountains are equally forbidding, but the river, angry and boiling, will recognize no obstructions, and rushes on with current unconquerable. The shooting of the Five Finger Rapids is an event to be remembered. We wonder between which relentless rocks our captain will elect to steer, for there are several of these natural narrow gateways. Slowly our skilful pilot guides our steamer through; we can nearly touch the lichencovered rocks, first on one side, then on the other, so narrow is the entrance. I fear, if she swings just a wee bit more, she will become wedged. Passengers are frankly excited. A moment more, and we have been safely conducted, and can now look back upon the thrilling scene, in which every sense has been exercised or gratified-beauty, joy, and fear. Again one must have a thought for the pioneers. They had to navigate these waters as best they could, their frail crafts slung about like so many corks. In hundreds of cases their golden dreams were foredoomed to disappointment.

The scenery is magnificent; the waters broaden; the foaming, hurly-burly rapids roll on for quite a distance. As we look back, the great reddish-brown stone portals are illuminated by a shaft of the golden sunset, and we continue along banks of most bewitching beauty. Six miles below, the Pink Rapids afford us another aspect of difficult navigation, 
for here is a whirlpool whose swirling eddies rival its grander neighbour. For miles we run swiftly past granite cliffs, foaming waters, overshadowed by the greater mountain-peaks in the distance, and countless uninhabited islands. Yukon Crossing is left behind. We do not tarry; the mail is taken off. We pause at Minto, where the winter trail begins and saves many miles to Dawson, as the Yukon makes a detour towards Stewart and the White River. Finally we stop at Fort Selkirk, where the waters of the Pelly River join in from the north-east, uniting with the Lewes, and now we have the Yukon proper.

In ancient times fierce were the battles fought around this district between the two Indian tribes of Pellys and Chilkats, who fostered an undying hatred towards each other. Fort Selkirk was built as an important post for the Hudson Bay Co. in 1850, and the Chilkats burned it in the following year.

Everyone remarks the absence of the big animals-moose, caribou, and bear. The explanation is that they have migrated to the Arctic, for this is their summer holiday. It is most romantic and fascinating to be alone in the primeval wilds, but there is the monotony and dreariness of the long winters, the deep snows, which must engender the sensation of being buried alive. No living soul is near, unless, perhaps, an occasional trapper, a musher or wood-chopper, and the shy, wild animals. This life for months on end must surely be trying.

We have just halted alongside a mud-bank, where are a couple of cabins of desolate appearance. The men come down to the landing-stage, and ask that their supplies be hurried up. They say they are very short of food; all their canned things have been used, and they exist only on what game they can kill. Such is life along the Yukon. During the entire run of forty-eight hours there has never, for Naturelovers, been a single dull moment. Every inch of the way has been planned by the Great Architect in a manner to enrich the mind and fascinate the eye, leaving medallions and pictures everlastingly impressed on the memory. 


\section{CHAPTER IX}

\section{HISTORICAL GLIMPSES OF THE YUKON TERRITORY}

THe earliest history of the Yukon territory is interwoven with the trading explorations of the Hudson Bay Co. In 1670 this far-sighted enterprise became incorporated by Royal Charter, granted by King Charles II. to "The Governor and Company of Adventurers of England trading into Hudson Bay." They were constituted "the true and absolute lords and proprietors" of the territory known as Rupert's Land. On the 30th of May, 1838, a licence was granted to the Honourable Adventurers, conferring upon them the exclusive right to trade in the Indian territories west of the Rocky Mountains. Such was the inception of this great company, soon to establish posts all over this vast Northland.

Captain Cook sailed from England on a voyage of discovery bound for the North Pacific on the 12th of July, 1776. In March, 1778, he anchored in Nooka Sound. Going northward, he passed Sitka on the 4th of May, when he observed and named Mount St. Elias. In August of that year he sailed into Bering Strait, and traced the coast north, and eastward to Icy Cape. Afterward he returned and explored Norton Sound. In 1786 the North-West Fur Trading Co., of Montreal, established a post on Lake Athabasca, and in 1789 Alexander Mackenzie, a representative of the company, discovered and explored the great river which bears his name. In 1792 Mackenzie again started from the post on Lake Athabasca, and proceeded down the Peace River. During the spring of the following year he crossed the Rocky Mountains and reached the Pacific Ocean, in the vicinity of Queen Charlotte Sound, on the 22nd of July. But before Mackenzie's arrival, Captain Cook's midshipman, Vancouver, had already explored and surveyed the coast from latitude $35^{\circ}$ 
to $60^{\circ}$ north. In 1825 Franklin commenced his second journey westward from the mouth of the Mackenzie River. Thus, within the period of fifteen years subsequent to 1778 , British seamen had discovered and explored the islands and western coast of what is now British Columbia, also a part of Alaska ; and representatives of the fur companies had also reached both the Pacific Coast and Arctic Ocean.

The Russians were actuated to explore more by the spirit of trade than by love of adventure. In 1646 a small fleet of Russian vessels, under the command of Isai Ignatief, sailed from the east, and reached a bay, where they bartered for, and obtained, walrus ivory. A few years later, further Russian ships rounded the north-east extremity of Asia and entered Bering Strait. They traded with the natives, and the lure of the lovely sables, sea-otter, and other furs, brought Russian rule to these shores. In 1824 negotiations began between Great Britain and the Government of Russia to determine their respective rights as to the boundary-line. By the treaty of 1825 Russia relinquished to Britain the region below latitude $54^{\circ}$, and also the vast interior occupied by the Hudson Bay Co., up to the frozen Arctic Ocean. In 1820 Sir John Simpson, who had been a clerk in a London counting-house, was appointed Governor of the Hudson Bay Co., and for close on forty years was chief of the company's fur trade and nominal ruler of half a continent. It was during the régime of Sir John Simpson that the Yukon territory was first explored by the company's traders.

A trading post on Dease Lake in British Columbia had been abandoned in 1839, and in the following spring Sir John Simpson instructed Mr. Robert Campbell to penetrate into the country and discover any river flowing to the westward, also to explore the north branch of the Liard.

Campbell left Fort Halkett in May with a canoe and seven men. After ascending the stream some hundreds of miles, far into the mountains, he entered into a lake of great beauty. which he named Frances, in honour of Lady Simpson. Leaving the canoe and part of the crew near the western extremity of the lake, and accompanied by three Indians and 


\section{GLIMPSES OF THE YUKON TERRITORY}

an interpreter, the party ascended the valley of a river and traced its source to a lake 10 miles long. Campbell christened the lake and the river Finlaison's. From this point he struck across to the Pelly River, which he thus named in honour of Sir H. Pelly, a governor of the Hudson Bay Co. A fort was built at Pelly Banks in 1842. The following year Campbell floated down the Pelly in a birchbark canoe to the confluence of a river which he called Lewes, after John Lee Lewes, one of the chief factors of the company. Here he encountered a large band of Wood Indians, who informed him that the Indians on the lower river were hostile and treacherous. Campbell returned to Pelly Banks, and during the winter of $1847-48$ boats were built. In June of 1848 Fort Selkirk was established at the junction of the Pelly and the Yukon, which the natives called Yukonna, meaning "the big river." Campbell descended the Stewart River, which was discovered in 1849 by his clerk, James G. Stewart, son of the Hon. John Stewart, of Quebec. $\mathrm{He}$ crossed on the ice. In 1850 Robert Campbell came down the river from Fort Selkirk to Fort Yukon, and so this hardy, brave pioneer was the first white man to pass the mouth of the now famous Klondike, and the site of the present city of Dawson. The Peel River was so named by that intrepid explorer Sir John Franklin, in bonour of the brilliant statesman Sir Robert Peel.

Gold had been found in the Yukon by Campbell and other traders representing the Hudson Bay Co. It was not until 1872 that several regular prospectors arrived in the Yukon. Amongst these real sourdoughs were Arthur Harper, Frederick Harper, Jack McQuesten, Alfred Mayo, James McKnipp, Mackey, Macdonald, and others. In 1874 Jack McQuesten established a trading post for the Alaska Commercial Co. at Fort Reliance, 6 miles below Dawson. Arthur Harper and Alfred Mayo joined McQuesten-" the father of the Yukon" he is called in the business. This trio built several posts, one at the mouth of the Stewart River and another at Fortymile, where, in 1887, gold was discovered. They also had posts at Fort Selkirk and at Ogilvie, 
opposite the mouth of the Sixtymile and Tanana districts. Thus began, and progressed, trade in the Yukon. I beg most gratefully to thank the officials for this information so kindly supplied me.

One cannot help admiring the sterling courage and splendid character of such men as Robert Campbell.

In the autumn of 1853 Campbell started on a most remarkable journey from Fort Selkirk to London, a distance of 9,700 miles, more than 3,000 of which he travelled on snow-shoes, in the dead of winter, through an uninhabited wilderness. What a wonderful testimony to the brave, intrepid spirit and tenacity of purpose of those adventurous traders! In the history of this country the names of Campbell, Mackenzie, Thompson, and Fraser, who risked life many a time, who endured every kind of hardship in opening up the vast resources of this mighty slice of the Dominion, should have an honoured place. They have, as it were, opened the gates for civilization, and countless homes for generations yet unborn. The Hudson Bay Co., since their advent into this great North-West territory, have been noted for their fair, straightforward, and kindly dealings with the Indians, always giving them friendly assistance and helpful advice.

Like a puzzle are the many different names of the Yukon River. For instance, sometimes it is referred to as Lewes, by White Horse some call it the Fiftymile River, by Lake Le Barge it is the Thirtymile. Then, at the confluence of the Pelly and Lewes it seems to drop its other cognomens and flow on, undisguised, as the mighty Yukon. In the summer of 1882 Joe Laduc and a party of miners crossed Dyea Pass, arriving at Fort Reliance, where they spent the winter. Laduc became successful and did a profitable trade at Ogilvie. $\mathrm{He}$ was well informed as to the different gold developments, and it was he who advised "Bob" Henderson, when the latter came up to Ogilvie for supplies, to prospect on the Indian River. In 1886 some 110 miners were rocking bars along the Stewart River, and they would average $£ 20$ a day per person during the season. Then coarse gold was discovered in the Fortymile River, and as soon as the news 


\section{GLIMPSES OF THE YUKON TERRITORY}

circulated a big stampede set in. The number of miners in the Yukon basin was said to be 250 , and there were more than 200 on the Fortymile, while the Stewart could only. claim about 50 miners. Returning to "Bob" Henderson's prospecting on the Indian River, it was he who advised George Carmack to try "Tron Deg," Klondike, and thus it came about that Carmack found shovelfuls of gold on Bonanza Creek, and, as Kate Carmack described, at Carcross " the floor was covered with gold."

In the year 1897 all the world was thrilled with the discovery of Klondike's gold. "A ton of gold from the Klondike!" was the cry that startled both the Old World and the New. Since 1885 the total gold shipment from the Klondike creeks and those tributaries to Stewart River, Fortymile, and the bars of those rivers, and elsewhere in the Yukon, was 200,000,000 dollars (two hundred million dollars). The largest nugget yet found was valued at 1,700.00 dollarsrather too heavy to wear on a watch-chain! 


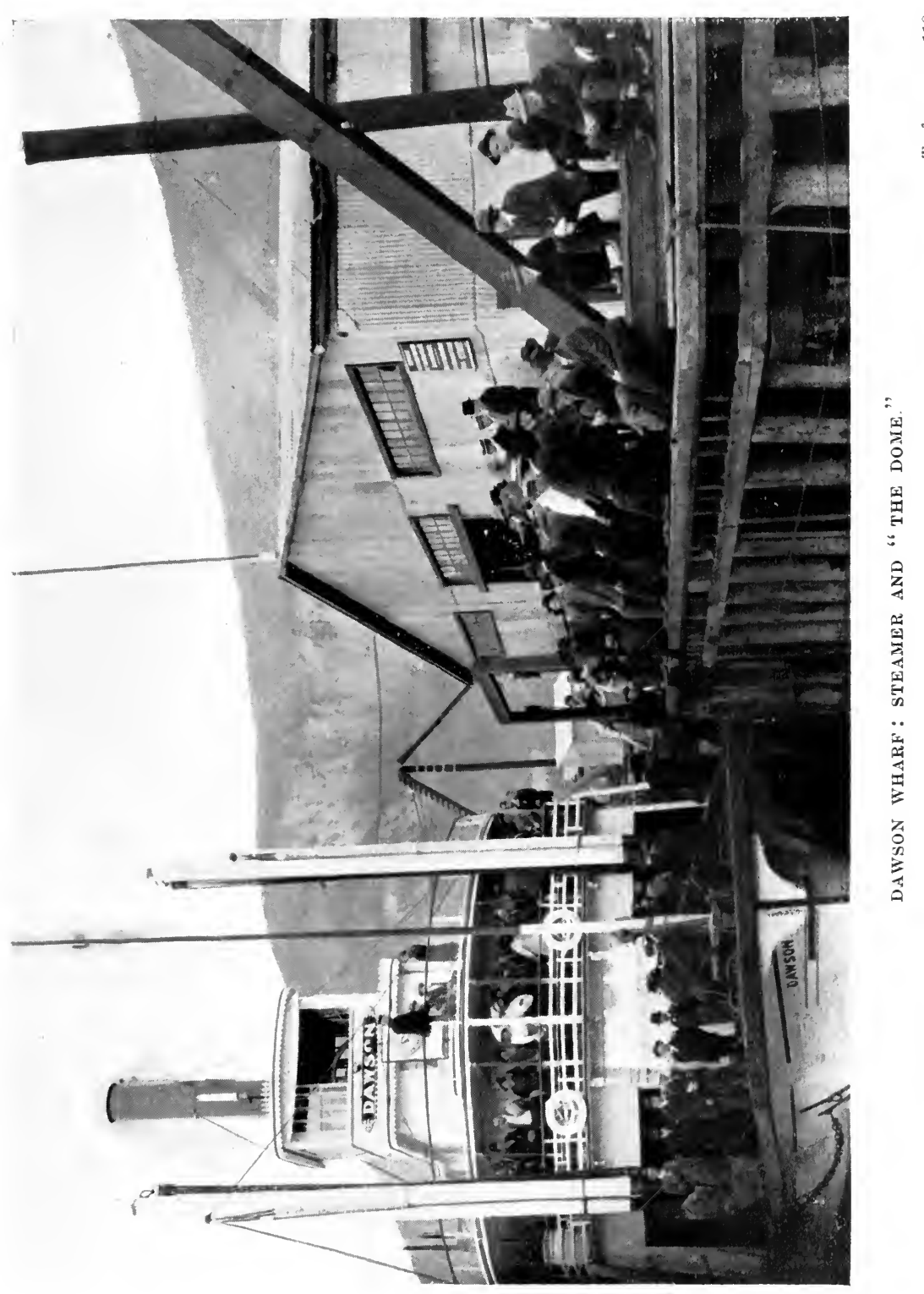





\section{CHAPTER X}

\section{DAWSON}

Dawson stretches along the river-banks for about $2 \frac{1}{2}$ miles. It comes upon one suddenly. The Yukon flows smoothly past low-lying green mountains-a peaceful rural scene; then, round the bend of a promontory, you are astonished to see a city laid out before you-Dawson, the metropolis of the Yukon. Very pleasant it looks, basking in the summer sunshine, well situated on a wide area of sloping ground, with the "Dome" Mountain rising to 1,800 feet protectingly in the background; on the opposite side high hills running into mountains; in the centre the blue, ribbon-like stream of the Yukon hastening on its course. If it looked good to comfortably guarded, well-fed tourists, what a haven it must have appeared to those thousands of gold-seekers who at last, after unbelievable dangers, arrived at the Mecca of their dreams. People on board at once inquire as to the nature of that scar on the side of the Dome. It is a huge bowl-shaped cave, the result, one would suppose, of a volcanic eruption. The naked earth is of a pale tan colour. "That's Moosehide," explained a Yukonite standing beside me. "You notice the colour is the same as that of a dressed moose-skin. That little village farther on is Moosehide also. It is said that ages ago a landslide took place up there, moving fearfully quickly and burying a whole tribe of Indians. It is curious that no vegetation has ever sprung up since." This arid spot on the mountain-side inevitably attracts you. It reminded me of Arrow Head in California. This also has an Indian history-a complete arrow is stamped on a mountain, with identical effect. "The Dome," continued our neighbour, " is called by some folks ' Sunset Dome,' and by others 'Midnight Dome.' There are two pretty trails winding up 
there: one is steep, and a good easy climb, but the other is more tiring. You see oceans of mountains when you get to the top." I mentally registered a vow to investigate the Dome. At the farther end of the town a large white building with verandahs might have been regarded as an hotel, but my kindly informant explained that it was St. Mary's Hospital. It was an agreeable surprise to see a hospital which would have attracted attention in any community almost within the shadow of the Arctic Circle. From the river-front wide streets bordered by houses and gardens run straight up towards the incline of the Dome. The side streets form squares, and everywhere gardens and vegetation meet the eyes. The Selkirk draws up to a long wharf, upon which nearly all the citizens of Dawson are assembled. One of the chief diversions of the people in the Yukon and Alaska is that of meeting the boats and seeing them off. Our little party, the Senator and Mrs. Heckman, Mr. Steffin, Miss Jackson, and others, scrambled our baggage together, bade adieu to captain and crew-they had done everything they could to render this voyage pleasant-and walked down the gangplank. The eyes of many Yukonites watched us curiously. The Alexandria Hotel across the way had been recommended to us-in fact, this year it was the only one open. It had borne a somewhat lurid reputation in the golden days, but, having changed hands many times since, was now, we were assured, "quite respectable." The main street consists of stores, warehouses, bars, and a few private residences. All the buildings are of wood, as are the sidewalks. The Alexandria Hotel is two-storied, with a verandah, upon which was strung a network of sweet peas growing in boxes. The rooms were small, peculiar as regards decoration, with rickety furniture which had seen hard service in the early days. Mine was a corner room opening on to the verandah. The walls were pale green, and a curious stamped tin dado was supposed to add to its beauty. When I looked in the mirror I could not help wondering how many "dance-hall jades" that glass had reflected, and where they were now. It was the room of the house, the proprietress told me, when she proudly 
escorted me thither. Therefore, one presumed that all the belles of the Klondike had occupied it at one time or another. I found out later there was little privacy to be had. The weather being warm, the windows had to remain open, and the verandah was a favourite resort. Naturally, accommodation is primitive. You cannot expect to find the CarltonRitz in these far-distant places, but if you are a sensible traveller you need not suffer for want of ordinary comfort. There is a bathroom, with hot and cold running water. Hotels in Yukon and Alaska usually mean rooms only, and you go out to a restaurant for your meals. Fortunately, "Eddie's" is next door; you either go there, or they will send your food in. This is more convenient than most places in the North. The price for my room was 3 dollars a day, others from 2 dollars. Your meals, according to what you order, will average $4 \mathrm{~s}$. to $6 \mathrm{~s}$. each meal for one person.

Dawson is a little dearer than some of the smaller towns, but living is expensive; so much has to be brought into the country, and freights are excessively high. Standing at my window, I look down upon the real sourdoughs. Two are coming along now, headed for the bar next door. Undoubtedly they are miners who have looked not wisely upon the "Old Scotch." They are very unsteady on their pins, a case of "blind leading the blind." They are dressed in slouch hat, flannel shirt, no coat, and high boots. As they slouch along, I overhear, "Got the trail, ol' chap?" Then a lurch, as if seas were running high. "I got the trail, Mac." Dawson will not join the prohibition circle for another month. These two have probably come in from the Klondike around the bend of the river, and are sampling the "Hootch." This front street was one string of bars in the old days. A lady of Yukon, then resident there, told me that respectable women never entered this thoroughfare. $\mathrm{Mr}$. Steffin, always keen on collecting furs, Miss Jackson, and I, started out to inspect the town. I had some letters of introduction, but as yet had not presented them. We walked along the rotting sidewalks, and were invited by "' Jimmy " to enter his shop. 
Now, "Jimmy," be it said, is a " character"; he knows his Dawson from A to Z ; he is a Greek and a " stampeder." In his shop one discovered all manner of Indian curios, cigars, chocolates, fruit, souvenirs from everywhere and anywhere, and postcards. One of his possessions was a Greek flag, proudly displayed, moccasins, beaded bags, white birch baskets, moose-skin coats, and caribou-head bags. "Jimmy" was most loquacious-told of the delightful "Midnight Sunners" who were aboard with us on the s.s. Princess Alice, and how merrily they had spent their time in Dawson. "Jimmy "-Oglow is his surname-was of the opinion there should be many more tourists in the land. He invited us to come in at any time, and make ourselves quite at home. You cannot help noticing the decidedly friendly atmosphere which greets you from the moment you arrive at Dawson. No one passes you without a bow, a greeting, or touch of the hat, which is pleasant when you are a stranger. We wander into the side streets of this bright town. The houses are small, the log-cabins are "dears"-indeed, I thought it would be delightful to live in a picturesque log-cabin with vines trailing over it, and masses of flowers in the garden. Nearly every house had its garden, and a vegetable patch as well. Some had small hot-houses in which one could see tomatoes and cucumbers growing. Lettuces, radishes, parsley, onions, and potatoes were planted alongside and doing well, and the flowers were radiant and varied. It must be remembered, again, that vegetable life here has the advantage of twentytwo hours of daylight. We observed that large lovely wildroses flourished wherever there was room. From every street corner appeared a charming view, whether one looked towards the Dome or on the other side of the Yukon. We are getting very fond of "our river," as we now call it. Is the spell of the Yukon upon us? We note schools, churches, shops, bars, boarding-houses, and good newspaper and book shops. During the light months of winter, when, for a long period, it is $40^{\circ}$ below zero, Dawsonites naturally are more than appreciative of literary fare. Pausing before a fur trader's, where there are huge bales of musk-rat, bunches of fox skins 
tied together, and enormous bear and wolf skins in the window, Mr. Steffin, with an eye to business, went in. We followed, for it is always interesting to see and hear about furs. Business formalities are taboo: in this Northland you are treated as a guest. Chairs are brought out and conversation begins; it is more like a visit than a bargain hunt!

During my war work in London $I$ had the privilege and pleasure of meeting Mrs. George Black, wife of the Governor of the Yukon, who formerly lived at Dawson, and did the honours of Government House. The Yukon could have sent to England no fitter representative than the charming Mrs. Black. She had given me letters to her relatives and friends here. As we sat chatting to the trader, this lady came into my thoughts, and I inquired, "By the way, do you happen to know Mrs. Black?" He put down the wolverine skin he was showing, leaned over the counter, and, eyeing me with renewed interest, exclaimed, "Mrs. George Black! Well, I guess I do-why, she's the finest woman ever wore shoes!" I had to laugh, the compliment was so all-embracing. There was nothing more to add. Then he was keen to learn how the wife of the former Governor was, and what she was doing. I replied that a year and a half ago, when I last saw her in London, she was doing splendid work, although her heart was almost breaking with anxiety, as her husband, Captain Black at that moment, was in the front line of the trenches, and I heard a few days after my conversation with her that he was wounded. Her elder son, Lyman, was fighting in France, and her younger son was in the Air Service. Yet, with all this dominating worry over precious lives, she spent three or four days a week visiting the poorest families, advising, taking care of, and cheering them. In the days of the strike she went to the mining towns and lectured. She is a woman the Yukon can be proud of. Governor Black relinquished the governorship at the call of his country, organized the " Black Contingent," and took his men over to France. At the present time Government House is closed, and Mr. George Mackenzie, the Gold Commissioner, is Acting 
Governor. Although the work is strenuous, he is assuming the dual functions with a great deal of success.

In walking past the several banks, one remarked the notice: "Gold-Dust Bought." The banks in Dawson purchase gold either in the dust state or dry amalgam. When the gold is presented, all foreign matter, sand, etc., is blown out of the dust by the buyer, and weighed in the presence of the owner. They have so much experience here in handling the precious metal that by simply looking at it they can invariably name the creek from which it has been taken. Therefore, if someone operated on another's claim and appropriated the gold, the robbery would at once be detected, with dire results to the robber. In the shop windows one sees long, narrow chamois leather bags-the "pokes" one has always heard of. They vary in size; some pokes will hold a couple of thousand dollars' worth of gold-dust. A fortunate miner coming to Dawson would throw his poke on the bar counter, and call for drinks for the crowd. At the dancehalls and variety shows, when a man became infatuated with a woman, he tossed her his poke of gold-dust. Women in those days practically sold themselves for their weight in gold -and got it! The local jewellery is interesting ; most of it is formed of tiny flake nuggets used as a setting for lockets, rings, and brooches. Larger nuggets are made into charms, cuff-buttons, tie-pins, small souvenirs to send home, such as tiny gold pans with microscopic nuggets in the bottom of the pan, models of the original pans used on the creeks, lockets of glass showing the crude gold-dust, and framed with small nuggets, as well as miniature gold shovels and picks.

The Government of the Yukon in 1894 was represented by a detachment of that splendid body of troops known as the Royal North-West Mounted Police, whose deeds of valour have gained the world's admiration. 'L'hey were authorized to represent all the different departments of Government in the district. Inspector Constantine was in command. In 1895 the mining industry had expanded so enormously that the inspector could no longer cope with all his duties. A special officer was appointed to take charge of the customs, 
and in the following year a Gold Commissioner was elected. At that time the recording office was removed from Fortymile to Dawson. In 1898 the Yukon was created a Territory by Act of Parliament, and provision was made for local government by a Legislative Council composed of a Commissioner and six persons appointed by the Governor in Council. On the 2nd of December, 1902, the Hon. James H. Ross was elected first member of Parliament to represent the Yukon Territory in the Canadian House of Commons.

Mr. Alfred Thompson, M.D., M.P., is now the Federal representative of the Territory in the House of Commons. For nearly seventeen years Dr. Thompson, who is greatly beloved and respected, practised his profession in Dawson. $\mathrm{He}$ was appointed in 1904 . The Yukon Territory Act provides for the appointment of a chief executive officer to be styled and known as the Commissioner of the Yukon Territory. The Commissioner, or Governor, administers the affairs of the Territory under instructions from time to time given him by the Governor in Council or the Minister of the Interior. The Yukon Council is composed of ten members elected to represent the electoral districts in the Territory. All naturalborn or naturalized British subjects of twenty-one years of age who have been in the Territory for twelve months are entitled to vote.

Every Commissioned Officer of the Royal North-West Mounted Police can exercise in the Yukon Territory all the powers of one or two Justices of the Peace, under any laws or ordinances, civil or criminal, in the Territory. Colonel Knight is the commander of the North-West Mounted Police at Dawson, and resides here with his family.

The Administration building is a large, handsome, sensibly designed frame structure of three stories, set in a commanding position, with spacious grounds, flower-beds, and shady trees. One might describe it as Dawson's House of Parliament, as here most of the official work is transacted. The Commissioner has his offices and the Court its rooms. I had the pleasure of being shown over the building by the courtesy of Mr. George Mackenzie, and was much impressed by the 
interesting information accorded me. The rooms were steam heated and electrically lighted. Native woodwork, highly polished, was largely used in the structure, testifying to the beauty and utility of Yukon's forests. The rooms were spacious and furnished in excellent taste. The tinkle of telephones on huge desks emphasized the modern note in Dawson. The maps were especially attractive. In the High Court the criminal and murderer's boxes were pointed out to me, and I was told many stories of the various causes célèbres. No greater compliment could be paid to the North-West Mounted Police than that based upon their uncanny success in the tracking down of murderers. In all the Yukon, since the days when law and order was first established, out of thirteen murders, twelve criminals have been caught and hanged. The one who escaped the noose died before the date set for his execution. If wanted for crime in the Yukon, with the Mounted Police on your track, you may be certain that sooner or later you will pay the penalty. Hours could be spent in the fireproof recording room, among those huge calf-bound ledgers, wherein can be traced the rights, claims, and ownership of the mines from the first staking. El Dorado, Bonanza, and the more famous of Yukon claims recovered therein, were items of interest. Close to the Administration building is a park, where the games dear to the hearts of British boys are in progress. Farther on are the trim, well-built barracks of the Mounted Police. Dawson, by the way, derived its name from Dr. George Dawson, who was Director of the Canadian Geological Survey. We dine at "Eddie's," or, to be strictly accurate, at the Arcade Café, which, as I said before, is next door to my palatial hotel. Most people are called by their Christian names at Dawson, the reason being that in so comparatively small a place they are like one big family. "Eddie's" surname is Mackenzie, and he waits on you himself, He is a fine chap, with great faith in the Yukon. He helped us in choosing our repast, and as you glance over the menu you will appreciate that, being cheechakos, we needed expert advice in our choice. I append part of the list; the phrasing is theirs : 


\section{All-Yukon Dinner.}

See here what Yukon development has done to date. Here is the proof that Yukon is a great producer of food-stuffs. Note that in the following bill of fare, being served this week at the Arcade Café, at Dawson, Y.T., every item here mentioned is a product of some Yukon farm, forest, or stream.

I will not bore my readers with the entire menu, just mentioning a few dishes that impressed us.

Boiled Yukon King Salmon. Klondike grayling.

Hot-house salad. Stampede sauce.

Bonanza dill pickles. Cream of Dawson chicken soup.

Grilled caribou steak. Sauce Dawson.

Mushroom sauce and Yukon silver chips.

Grilled Bonanza pig. Sourdough sauce.

Tournadoes of White River Mountain. Sheep sauce.

Chicken El Dorado with Klondike celery.

Moose steak à la Chieftain. Potatoes Tom O'Brien.

Flat Creek veal à la Jackadallee.

Peel River caribou chops. Yukon green peas.

Trio of Baby Mountain sheep chops with glacéd West Dawson spuds.

Throe-minute Pelly sirloin with Sixtymile sauce.

Dessert.

Rocky Mountain ice-cream. Goldfields whipped cream.

Sourdough blueberry cobler.

Pies all kinds. Klondike butter.

Klondike milk. Native smearcase.

The menu ends up with :

Arcade Café, most famous restaurant in the land of the Midnight Sun. All-Yukon Dinner the meal that keeps the money at home, and proves that Yukon is in the great food-producing belt of the Continent.-Proprietors: Mackenzie and Gleaves.

Such is the enterprise of the Yukon. "Eddie" is a specimen of what the Americans would call " all there." We chose, or at least " Eddie" performed the service for us-

Yukon salmon (delicious), price 3s. per portion.

Hothouse lettuce, stampede sauce.

Mayonnaise with peppers.

Grilled moose steak, Yukon silver chips, fried potatoes.

Moose steak is excellent, as good as any beef-steak, tender, and with the slightest game flavour. Rocky Mountain icecream was refreshing, but it was made, I fancy, of condensed cream and dried eggs. 
Ice-cream sodas are favourite drinks of Dawson. We passed several " Ice-Cream Parlours," as they call them.

The dinner we enjoyed immensely, as also the anecdotes of " Eddie" concerning the lurid nineties.

" Out there," motioning to the main street beyond the open doors, " 30,000 people were in Dawson. Money! why, it was nothing ; champagne at $£ 6$ a quart, you could float in it, so much was opened. Men thought only of having a good time; they didn't care what it cost. Thousands were thrown down here of a night." I stared with widening eyes. I had always had the greatest admiration for Robert Service's wonderful poems, and here was $I$, right in the heart of the places he has immortalized-oven my hotel had at one time been kept by the " Lady who was known as Lou," and who, according to Service, was the " light o' love of dangerous Dan Magrew, and pinched the Poke."

"Eddie" continued: "One man lost his heart to a barmaid-those barmaids flourished, I can tell you. And the diamonds! Whew! This particular man came in from the creeks, reeking with money. There was just one dozen of eggs in Dawson at the timo-in dead of winter; the barmaid fancied them, and the man bought the lot for 300 dollars." "Just imagine," I said to Miss Jackson and Mr. Steffin“ $£ 12$ sterling for a dozen of eggs !" “ Eddie ” had a 'phone call, and so withdrew, promising us a further instalment of stories on the morrow. We sat sipping our coffee, amazed at all we had seen and heard. This restaurant was composed of a long line of boarded cubicles, reminders of the days when gold-dust practically carpeted the floor. Ours was painted green, with green curtains. Outside was \& long bar, with a few open tables. We wondered in our minds what story our special green cubicle might have told, could it have spoken. Had it been the scene of some passionate tragedy? Had some impassioned miner shot straight, and an unfaithful houri paid the price? Had they really bathed in buckets of champagne? Did their shadows ever return and re-enact once again their loves and their hates?

In these cubicles men had doubtless been drugged and their 
gold stolen. We became quite excited, simply by permitting our imagination to run wild.

Mr. Steffin suggested we had better climb the Dome. It was getting on towards midnight, and about 11 p.m. is the favoured time to begin the ascent of the mountain. Time is forgotten in this part of the sphere; people are up all night. We go out into the street. It is bright daylight, softened only in slight degree. The mosquitoes are lively. I retire to my room and clear off many arrears of correspondence, able to see perfectly well without artificial light. Downstairs in "Eddie's" bar there's a rag-time tune, piped out by an ancient gramophone, and between pauses I hear the singsong of sourdoughs who are making a night of it.

Having sent out the letters of introduction which Mrs. Black had so kindly given me, the following day I was kept busy receiving. As the old saying goes, "It's good to have a friend at Court." My first callers represented both the civil and military society in the persons of Mrs. George P. Mackenzie and Mrs. Knight. They arrived in state, seated in a light two-seated open carriage drawn by a fine pair of horses and driven by a smart sergeant of the Royal NorthWest Mounted Police. I had a glimpse of them from the verandah, and noted that both ladies were white-gloved. The Court had come to pay its compliments in honour of Mrs. Black's friend from overseas. I immediately pulled on my white gloves and went down to meet them. Britain is Britain the world over. How many of these semi-Courts or official offshoots of Empire I had met with in my travels all over the far-away portions of the globe! I was sorry not to have been able to receive my visitors in my own home, and give them tea out of the china and silver of civilization, but one cannot carry one's possessions to these far-flung spaces. Therefore, our State visit was conducted in a rather stuffy, small sittingroom through which people were continually passing. After a few minutes, formalities were cast aside, and we were chatting as women will, they asking me all manner of questions about England, and the latest news of their friend Mrs. Black. Tea arrived, the cups rather thick, and old family 
silver represented by pewter spoons! However, it was all that I could obtain, and they did not seem to mind. Mrs. Osborn and her pretty young daughter came; Mr. John Black, Legal Adviser and Public Administrator, who at that time was acting as Judge of the Courts; Mr. Charles Black, the former Commissioner's brother; Mr. and Mrs. Lee; and Mrs. Charley Boyle. They were all so frank and kindly that before long I felt they were quite old friends. Senator Heckman and Mrs. Heckman joined us. Now, thanks to the thoughtfulness of Mrs. Black, I was fairly launched in Yukon society. Many invitations were showered upon me; everyone was anxious to show me something of the country. It was arranged that I should give a lecture, see the creeks, the fox-farms, and, in fact, everything worth seeing. No people could be more hospitable, genial, and kindly than these Dawsonians. From that afternoon every moment of my time was apportioned for my week's stay. With Mrs. Knight and Mrs. Mackenzie in the smart little carriage, driven by the gorgeous and dashing Mounted Police, I visited Dawson from end to end.

Many people are familiar with the uniform of the NorthWest Mounted Police, but for those who are not I will describe the picturesque ensemble: large-brimmed tan felt hats, bright scarlet coats, dark breeches with scarlet stripes, and high boots. We went to the St. Mary's Hospital, spotlessly kept, and looking so comfortable one felt like staying there. The city is up to date in every respect; the public school is a fine building, and was built soon after the gold rush in 1901. It has been extended at various times, and graduates can take courses in Arts, Law, Medicine, or Engineering at the different Universities-e.g., at Toronto, McGill, Chicago, Leland Stamford, and Yale. The fire drill is efficient. Pupils can vacate the building in half a minute after the sounding of an alarm. There are many fraternal societies-the Masonic; the Arctic Brotherhood, which has a fine handsome hall; Oddfellows, Eagles, Moose, the Yukon Pioneers, and churches of most denominations. The City Building is a huge erection which cost about 40,000 dollars. 
Most Dawsonians, young and old, are frequenters of the City Building, it being conducted more or less on the lines of a club. There is a skating rink, a large hall for receptions, shower-baths, reading and writing room, billiards, a gymnasium, and courts for tennis. In the winter everyone forgathers here. Mrs. Mackenzie desired me to see Government House, and I was anxious to view Mrs. Black's former home. The Commissioner's residence is finely situated; the Yukon River rushes past its front door, and its neighbour is a church. A large frame house with deep verandahs and shady trees, it lacks nothing in the way of comfort. The interior is handsomely furnished. In the hall are fine specimens of moose and caribou heads. A portrait of Queen Victoria as a girl and a fine cedar chest arrest one's attention. The steam radiators testify to the comforts when zero and 40 below are registered in the outer world.

Mrs. Black had won many prizes for her specimens of wildflowers, preserved by some special process, which she alone understands. She had left many framed specimens, so natural in colour and arrangement you would imagine they had recently been gathered. We wandered through the billiard, blue, bird, and other rooms, admiringly. The whole house was kept in perfect condition. In the event of the Prince of Wales caring to include Dawson in his itinerary of Canada, His Royal Highness would have been well housed, as well as enthusiastically received. Upon passing the study I was much amused at a card which read as follows: "Swearing positively forbidden-not that we care a d-, but it sounds like Hell before strangers." Walking homeward through the residential quarters, Mrs. Mackenzie would say: " In that house five of the family perished in the wreck of the Sophia, seven from this one, three from this. Dawson lost over a hundred townspeople. It was terribly sad. Some had worked hard, made their fortunes, and were dreaming of life as they wished it to be. It was a terrible shock to us." From Juneau up, many people had told me of their friends who had gone down into that icy grave. "You should be here in the winter," continued Mrs. Mackenzie; " the sleigh- 
ing, toboganning, snow-shoeing, curling, dog-toams-we have wonderful times." " Bu.t don't you nearly freeze?" I asked. "Nonsense," she retaliated. "We are dressed for it; our log-cabins are warmer than any house; we never let the fires out. Besides the sports, we have many dances, parties of all kinds. I came in, my husband and I, last February, delighted to get back to my little log-cabin. We had stayed for some time at the Château Laurier at Ottawa, but I felt the call of the Yukon, and wanted to come back ; my husband was just as keen to return." " From White Horse, how do you travel in winter?" I inquired. "We came over the trail in the stage, four horses, hot bottles at our feet, and well covered in furs. The air is crisp and gloriously exhilarating. We stop at the different Road Houses to sleep and eat." In walking along past the cosy homes and pretty gardens, we passed a cabin desolate of aspect, weeds, instead of flowers, decorating the front garden. On the door a sign read: " Jerry Doody, Photographer. Gone to California; will be back soon (broke)." The information given was certainly unique. Very pleasant was this walk leading up to Mrs. Mackenzie's residence. She could give me accurate knowledge of everything of interest in Dawson, being a veritable sourdough who had lived here for years. I asked her about agriculture and its possibilities here. She replied: "There are many large farms all about Dawson, over those hills and across the river. The farms vary from 50 to 150 acres or more ; potatoes are money-making crops, as well as oats, hay, and all kinds of vegetables, for very good prices are obtained. Wheat-land has produced as much as 60 bushels to the acre in these parts."

By this time we had reached the log-cabin so dear to the heart of my hostess; the bright red of the Union Jack flutters in the zephyrs of a summer day, and the emerald background of the Dome affords an effective setting. From here one looks down upon the whole of Dawson, a charming panorama. All along the sides of the board-walk are masses of wild-roses, a much bigger bloom than we have in England. Mrs. Mackenzie's garden is a delight to the eye, rich in flowers. 
The dearest log-cabin with a verandah, this is in reality the official residence at present. This explains the Union Jack, as $\mathrm{Mr}$. George P. Mackenzie is both the Commissioner and Gold Commissioner this year. But owing to adverse conditions, the impossibility of securing servants, the general post-bellum chaos, Mr. and Mrs. Mackenzie prefer their log-cabin home.

It is really surprising to acquaint oneself with the interior of these so-called cabins. From the outside you would imagine them to be tiny, but when you are inside they almost stretch to halls. We entered a large living-room, very comfortably and nicely furnished, and an excellent tea was served. Several people arrived, and Mr. Mackenzie gave us a little of his precious time. Sitting on the verandah, my thoughts flew back to London. How far away it was, and yet how English it was here in this Northern outpost of Empire! I had had the good-fortune to have been a guest of H.M. the King at the great ceremonial festivities on the occasion of the Imperial Durbar in India; had enjoyed the hospitality of the Crown at Lagos, West Africa, and other places. And here was I having tea with a Commissioner and his wife representing the Empire in this great Northland, almost on the borders of the Arctic Circle. Yet how small the world is, and how homelike to see that familiar flag!

Wherever there is an assemblage in the Yukon, conversation inevitably drifts back to the old days of the adventurous gold-seekers. In 1898 George Mackenzie came from Nova Scotia. He was of a strict Scottish family, who kept to the narrow, undeviating, righteous paths which Bobbie Burns so well describes. He did not venture by the Skagway route, but came up the Stikine River on the ice, and, as he told us, his experience was unpleasantly thrilling. He was driving, alone, a pair of horses; on his sleigh was piled his outfit, all his worldly possessions. It appears that the current had undermined the ice, and, without a moment's warning, it commenced to crack. Mr. Mackenzie jumped, landed on the ice, and there he sat on a floating ice-cake. He never again saw a glimpse of horses, sleigh, or outfit. The Stikine River swallowed all. "You must have had a charmed 
life," I suggested. " That's only one escape out of many," he laughed, this tall, big, fair Scotsman.

In speaking of the shortness of the summer season, he said : "The Yukon is generally navigable from about the 10th of June till the 5th of October. Lake Le Barge hinders navigation, as the ice there does not break up until some three weeks after the general melting of the Yukon River ice." The Commissioner was assuredly under the spell of the Yukon. Firmly and convincingly he remarked, " There's no place like it." That evening I dined with Mr. and Mrs. Lee. Theirs was a two-storied wooden house. I greatly prefer the picturesque cabins. Mr. Lee had " stampeded " from Edmonton, and it took him ten months, hauling his sleds and his pack. Accompanied by a bosom friend, they hewed down trees en route, and built their own boats on which to cross the many streams and lakes. They lost more than half their kit, lived on beans and baked flour-real sourdoughs both. After desperate struggles, very lean and hungry, he and his pal arrived, two among many thousands of people of every class who then flooded Dawson. They slept and lived anywhere-in tents, outside on the shore, it did not matter. All thoughts were of gold. In their speech, in dreams even, people madly talked of nothing else. The entire fortune of himself and his chum amounted, on arrival, to one dollar. They landed at the Klondike side, and it cost a dollar to get over to Dawson on a sort of ferry-boat or skiff. They tossed up as to who should go, and Mr. Lee won. In the main street of Dawson one could scarcely find standing room, it was crowded to such an extent. And still every day more adventurers arrived. Mr. Lee had spent his last dollar. "What is to be done?' he asked himself. Having a fishing-line in his pocket, he tried his luck, caught two grayling and three suckers. A man hailed him: " I'll give you a dollar for each fish." Mr. Lee gladly took the five dollars, went over and "redeemed" his pal, and with the rest of the money bought flour and beans. After that they felled trees until they got another start. Mrs. Lee at that time was a patient fiancée in England. It was most difficult to secure delivery of letters 
from home. A sort of shack had been put up, and one dollar was charged to inquirers for letters. The men stood for hours in queues. If lucky enough to receive a letter, you were obliged to pay another dollar. Men who had struck it rich on the creeks would pay as much as twenty dollars for a place close up in the line; quite a business was transacted in selling a place in the post-office line. It was then a common question to ask a man, "Where are you bunking?" just as we might inquire, "What hotel are you at?" These bunkhouses afforded shelter, if not comfort, and five dollars, ten dollars, and twenty dollars were asked and paid for a night's accommodation, according to the demand. Bunk-houses still exist in the country, especially in Alaska. Arranged tier upon tier, you would have to slide in your bunk sideways, and lie flat when you got in. No sitting up in bed in a bunkhouse! Meals, consisting of stews, were served in a washtub; one took a plate and scooped it up. Soup would be made in a bucket. Armed with a spoon, you dived in and helped yourself. And yet the crowd poured into Klondike, from St. Michael's up the Yukon. Some came viâ Stikine River and Lake Teslin, others chose the Arctic Plains and Mackenzie River, even from Valdez and Cordova. Thousands passed through Skagway, where "Soapy" Smith and his gang lay in wait for the moneyed tenderfoot, frenzied for gold. In those days Mrs. Lee in England looked in vain for letters, never knowing if her betrothed had survived or not. But as soon as he saw his way clear to make a home, the magic letter was sent, and she came out to share his fortunes. A fine son was upholding Yukon's reputation in France, not then having been demobilized, and a pretty daughter assists her mother in preparing our meal. I have the greatest admiration for the women in the North, every one of them. It is astonishing how they manage their homes, bearing in mind that practically none of them have a servant, yet their houses are spotless. You go to dine or lunch with them, and the hostess is dressed in white, or a lace blouse, looking as if she never entered her kitchen. In a few moments an appetizing meal is served, including hot biscuits (or rolls, we 
should say), soup, a roast, vegetables, and delicious pies and cakes. It has been a revelation to me, and I thereupon decide as soon as I return to London to attend a cooking school. Presumably I could grill a steak or chop in ordinary fashion (very ordinary), but these women seem naturally born cooks, and when you remember that half the food is of the canned variety, and that they haven't many of the ingredients we have at hand, the result is even more remarkable. I asked Mrs. Lee about it. One had to learn how to cook well, she said, because all the men were connoisseurs, having had to do their own cooking, and in many cases having taught their wives.

Mr. Lee told of a moneyed man, Carl Halfstead, who developed cancer, and from his cabin used to watch Haystack Mountain. He became so enamoured with this 3,000-foot conically shaped mountain that he arranged for his pals to bury him on its summit, he making provision for a barrel of beer for the bearers. It was in the winter, and it being impossible to handle the stiff, frozen corpse, they made a fire and tried to thaw it, but could not manage it. Then they chopped him up a bit, because they had to haul him up by ropes. Three times the remains slid into the glacier, and they had to get them out. Finally, said my veracious informant, they managed it, with the help of the beer, and there Halfstead awaits the resurrection on the top of Haystack Mountain.

The clock has crawled on to 2 a.m. Mr. and Mrs. Lee walk to the Alexandria Hotel with me; they even invite me to have a snack at "Eddie's" restaurant. No one thinks it unusual to go in and take a meal here at any hour of the night or morning. Why, in this wonderland, they have to shut up the fowls and chickens, otherwise the birds eat and scratch the entire twenty-four hours, and would never fatten. In all my travels this country certainly stands out as unique. The next afternoon I visit, with Mrs. Mackenzie and Mrs. Knight, Robert W. Service's little log-cabin. It has a place on the sloping sides of the Dome, on the corner of Eighth Street, which some of the people would have renamed after 


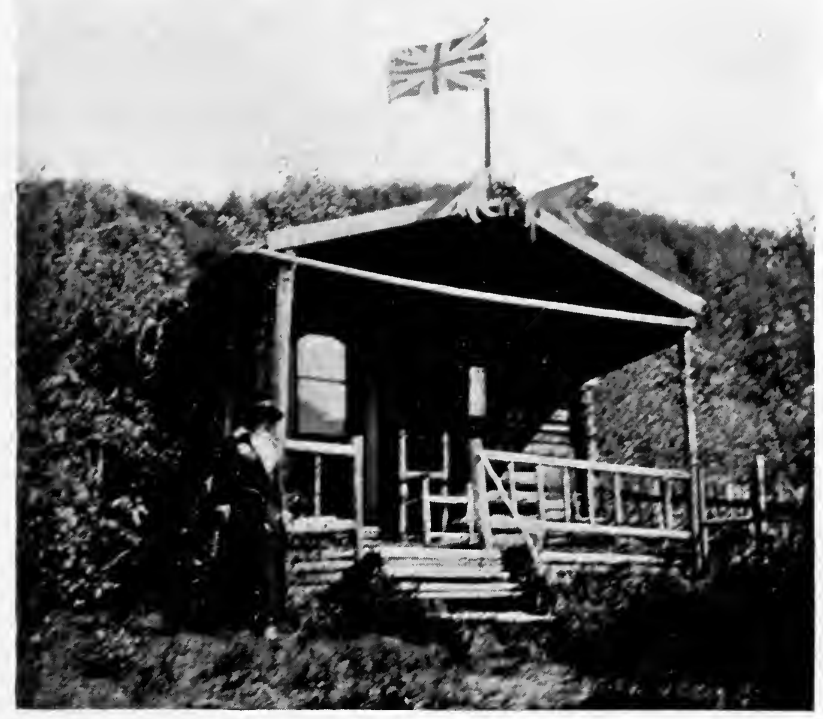

ROBERT SERVICE'S LOG-CABIN AT DAWSON : THE WRITER STANDING TO THE LEFT.

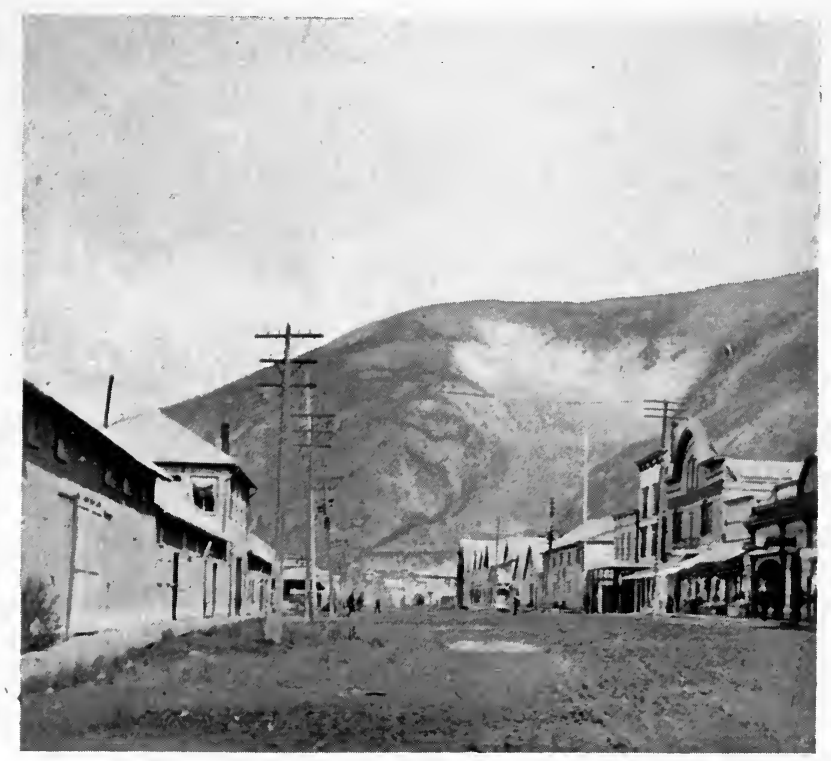

A MAIN STREET, DAWSON, "THE DOME" IN THE DISTANCE. 

the poet. I think the request is perfectly natural, because no one has ever described the Yukon as Service has done. His was the true spirit and genius of this vast Northland; thousands of people, after reading his wonderful poems, will long to visit the country he has immortalized. I have never met Mr. Service, and probably never shall, so I have no axe to grind, nor any personal reason to eulogize him. But genuine admiration I certainly owe him. He has clearly made me see the "valleys brimful of hush, the lone trail, the mountains heaved to heaven, the black canyons where the rapids rip and roar." Service's cabin is entirely rustic, overgrown with wild-roses, weeds, vines, pussy willows, bluebells, and yellow mustard flower. It is set back from the street, surrounded by a decaying fence of saplings. Moose, antlers, stark and white, decorate the front porch, silhouetted against the blue sky, and a hornet's nest hangs under the rafters. At the back frowns the Dome. The neighbours tell you that this was a favourite stroll of "Bobbie's"; he would spend hours there absorbed in meditation. From this height he gained his inspiration, his impressions of solitude, space, and love of the untrampled wilds. The old flag flies over the roof of this old, crumbling, and lonely place. The custodians live next door ; they charge you a nominal fee of 1s., and you enter through the gate. The tiny porch where he dreamed his dreams is going to dust, as are the steps, but the view from here is charming. Nailed on the logs outside is Service's poem, "Good-bye, Little Cabin," which describes it perfectly. Here are just a few lines:

Your roof is bewhiskered, your floor is aslant, Your walls seem to sag and to swing;

I'm trying to find just your faults, but I can't, You poor, tired, heart-broken old thing!

I've seen when you've been the best friend that I had, Your light like a gem in the snow;

You're sort of a part of me-gee! but I'm sad; I hate, little cabin, to go.

I hear the world-call and the clang of the fight; I hear the hoarse cry of my kind;

Yet well do I know, as I quit you to-night, It's youth that I'm leaving behind. 
And often I'll think of you, empty and black, Moose antlers nailed over your door;

$\mathrm{Oh}$, if I should perish my ghost will come back To dwell in you, cabin, once more!

We entered his tiny sitting-room; it is just as he left it. As Bobbie Burns dreamed in his crofter's cottage, so Bobbie Service rhymed in his log-cabin under the Northern Lights, each offering to humanity the fruits of the genius bequeathed them. Service's room abounds in mottoes. The first one you remark is " Don't worry, work." In a corner one reads "Rebuffs are only rounds in the ladder of success." Another, "Difficulties are only strength tests." The roof was slanting, and had been papered white. A door, over which was nailed a rusty horse-shoe, and two small windows completed the details. A chair which had been fashioned out of a tree-trunk, a table, a lamp, and a stool, comprised the cabin furniture. Over the inner door leading to his bedroom hung the snow-shoes of the poet. A cabinet made out of a starch box, hanging on a wall, held some old pipes, a tin box with fragments of tobacco, and a pin-cushion. His sleeping apartment would not arouse envy. Just a narrow camp bed under the eaves, a window, a minute mirror, and an old rickety chest. The other room, or cubicle, served as a kitchen, and was entirely papered with old newspaper photos of famous people and beautiful actresses. On the diminutive. Yukon stove Service cooked his food, washed his dishes, and arranged his shelves. I am hopeful that some day he will return before the cabin falls into the dust.

Robert Service was born in England, but was brought up and educated in Scotland. $\mathrm{He}$ attended the Glasgow University, and when about twenty-one came to Canada and thence to Dawson, where he occupied a position in the Bank of Commerce. I called at this bank to cash a draft-it seemed strange to think of Service behind the banking counter. They appeared anything but interested when I inquired if Service really had worked there. In temperament, they said, he was very quiet, more of a listener than a talker, and he was fond of solitude. After he became famous 
and money poured in from the sale of his books, hostesses endeavoured to lionize him, but unless he really liked them he would not accept their hospitality. Some even accused him of being unsociable. However, his neighbours, the present custodians, were exceedingly fond of him. They tell you how late at night Bobbie used to work; how they would watch his light in those long winter nights, and how proud they are of him. It is plainly seen that they love the little log-cabin for its associations. If one has not yet read Service's poems, his three first books are the best; his vivid pen-pictures of this great Northland cannot be forgotten.

From Dawson to Moosehide-an Indian village $3 \frac{1}{2}$ miles down the Yukon-in a canoe is a pleasant excursion. You can observe the Indian mode of life, make the acquaintance of their chief Silas, and purchase the baskets, moccasins, and various curios cheaper than in the shops of Dawson. The Dawson Daily News, which recently celebrated its twentieth birthday, is a thoroughly up-to-date newspaper, and subscribes to the service of the Associated Press, getting its news direct from the great centres of civilization. Mr. Charles R. Settlemier is its able editor and manager.

As a compliment, Mrs. Herman Franklin Osborn, and several of the Dawson ladies, arranged a Wild-Rose Festival, at which I was to give the lecture on travel, " Africa and the Former German Colonies," which I had delivered throughout England and the United States in aid of various war charities. In this case the proceeds of the entertainment were to be devoted to " The Daughters of the Empire." It was a beautiful evening, and when I arrived at the Arctic Brotherhood Hall, where the festival was to be held, the decorations fairly amazed me. The vast pavilion was a garden of wild-roses, many rare exotics embellishing the scene; but the lovely wild-rose was the belle of this floral galaxy. Thousands of wild-roses there were, bud and blossom. The hall was gay with Allied flags, and the Service Victory Flag of Dawson, with its twenty-one crowns, spoke of local patriotism. I have never seen a stage so beautifully decorated, a very bower of wild-roses. The Commissioner, 
George P. Mackenzie, presided, opening the "Festival of the Wild-Rose" with a very well chosen and happy address. Mrs. Mackenzie, who has a very fine voice, sang, and was encored again and again. Mrs. Richard Oleson rendered musical treats, Miss Rynetto Malstrom, who hailed from Seattle-a beautiful girl with a sweet soprano voice-sang with great feeling. Then I "travelogued" for a bit. Dancing followed; they are as fond of dancing in the North as in any other part of the globe, and they dance well. A stately minuet in which Mrs. Mackenzie and Mr. John Black took a graceful part was a much admired feature. Ice-creams and light refreshment added to the benefit of the funds, and Mrs. Osborn and the ladies of the committee received enthusiastic congratulations and thanks for organizing "The Wild-Rose Fête" - this within the shadows of the Arctic.

Practically everyone in Dawson was present, and amongst the interesting people who were introduced to me was $\mathrm{Mr}$. Robert Henderson, the first discoverer of the Northern treasure. We had a long talk. Mr. Henderson is a tall, thin Scotsman of sixty-two, with a fine upstanding figure, grey moustache and hair, good features, and eyes of steel blue. He interested me very much, as he told of the long, weary trails he had taken, and how in the lone stillness he had talked to himself. It was much better for men to do this, he said, otherwise they sometimes lost their reason. Soon in a few days he will again take the trail and "mush" for miles, always in search of that rainbow of hope that another Bonanza or El Dorado will reveal itself to him. And if it did, he would have little use for it. It is not the value of the gold that attracts them; it is just the finding of the gold, the excitement, the gamble of it all. "Bob" Henderson, as everyone calls him, need not take the lone trail; his wants are few, he has a pension from the Government of $£ 10$ a week, besides other moneys. He took from his pocket a small corked bottle. I wondered what it could contain. " That's 2,000 dollars' worth of gold-dust," he said. It did not look up to much, like dark-coloured powder in which were yellow specks. There are so many stories circulating 
as to how Carmack really found the gold that I thought "Bob" Henderson himself would be the one to dispel all doubts on the matter. This is his version : George Carmack was lying on a settee sleeping, and " Skookum Jim," Kate's brother, went down to the creek, saw some yellow pieces, and eventually picked up a whole hatful of nuggets. He called to Carmack, who came, and they picked up further hatfuls. Then Carmack at once staked out the claims for himself and his two Indian companions. Carmack realized millions, went to Seattle and San Francisco, bought a grand motorcar, went about in state, a big placard attached to his car announcing "The discoverer of the gold in the Klondike." Henderson is a man of a shy, retiring disposition. He had failed properly to stake out certain claims, and for years litigation proceeded over his property. Therefore he did not reap the millions which Carmack grasped. I inquired about the Indians, whether "Skookum Jim" and "Tagish Charlie" were still well-to-do, but Mr. Henderson said he thought they had squandered it all. Women, cards, and drink ate up a lot, he admitted. We talked of the old country, and he asked questions, and was as glad to meet me as I was to meet him. The next day he called; unfortunately, I was out. The same evening he started out on a fresh prospecting trail. 


\section{CHAPTER XI}

\section{KLONDIKE}

ONE coming to Dawson would naturally visit the Klondike, the greatest "placer" mines of the world so far discovered. A most instructive and enjoyable day I passed there, thanks to the hospitable kindness of Mr. John Black. We were a cheery party as we piled into the motor-Mrs. Lee, Mrs. Charles Boyle, Mr. Charley Black, our host, and myself. Alongside the Klondike River we spun rapidly. Before the days of 1897 the river was a quiet place for the salmon fisher; then suddenly it leaped into world-wide fame, the magnet which attracted thousands. The road is good for 7 or 8 miles. On the one side the mountains, on the other the river. You at once remark the great silvery-white masses of tailings : in some places it seems as if the tailings must conquer the river, so much do they curtail and encroach upon the river bed. Mining certainly spoils the beauty of a country ; water is diverted into queer, false channels, the earth is torn up and thrown into waste heaps. It gives an impression as of the after-effects of a cyclone.

We first stop to visit a fine farm, where immense crops of potatoes and other vegetables are raised. Oats looked very flourishing, besides other grains. Produce here represents harvests as golden as do the mines farther on.

Soon we are looking upon Bonanza Basin, where the great dredgers and hydraulic machines are in operation. We stop to view a weird scene on the Yukon Gold Co.'s property at Lovett Gulch. There are many hydraulic plants on the various creeks in the Klondike district, but this company possesses one of the largest hydraulic installations in the world. During the five months' season the company handle over three million cubic yards of gravel. The sight of these 
powerful giant nozzles at work at enormous water pressure, ripping, tearing down what might have been called the everlasting hills, recalls old pictures of Dante's "Inferno." Just picture, at the outset, a high brown hill capped by scrubby pine and spruce. It is attacked by several of these giant nozzles with a pressure of 40 to 150 pounds per square inch. One can then appreciate the force exerted by this water-power in disintegrating the earth. I saw as many as four of these giant streams playing upon one mountain. Caverns were formed, then the mountain collapsed! Turreted castles would bend, then fall with a loud thud, as if an earthquake had shaken them. Still the merciless streams played on, ripping out the underpinning, bent on destruction. At times all streams reflected the colours of the rainbow, which played in circles, illuminating and beautifying the condemned earth. It reminded me vividly of the work I saw in progress when the Panama Canal was in course of construction. There, also, to watch the huge steam shovels and the automatic machinery was indescribably fascinating.

The deposit, a part of which is " white channel," so called, is usually rich in gold, the gravels either white or light grey in colour. Lovett Gulch and Trail Gulch, the channel of Bonanza Creek opposite these two gulches, constitute one mine, and are worked as such. The white (or pay) channel is located on the right limit, and extends from Trail Gulch through to Jackson Gulch on the Klondike River slope, a distance of $1 \frac{1}{2}$ miles. It is much greater in volume than higher up the creek, attaining a maximum width of 2,000 feet and a maximum depth of nearly 400 feet. The water used in these operations is conveyed from the Twelvemile River watershed, through a ditch system 60 miles long, to a point on the Klondike flat, where it is diverted for use at these mines. The system consists of ditch, flume, and pipe alternately, and delivers a maximum of 5,500 M.I. of water at this point when running to capacity. The same system extends up Bonanza Creek for a distance of 10 miles. The ditch which supplies the mines, and without which they could not be worked, is a marvel of modern engineering 
construction, vying with the great dam at Assouan, Upper Egypt, and the Panama Canal.

At the head of a mountain range is an up-to-date power plant, the powerful currents generated from which illuminate the works at night, and perform such useful offices as pumping, turning wheels, washing gravel, sluicing, elevating -a general help throughout. On the Lovett Gulch there are three independent sluice lines in which the gravel is dumped. These lines are each over 200 feet in length, 4 feet wide, 30 inches deep, and are paved with both longitudinal and crosswise riffles, fashioned of manganese steel, with which to catch and imprison the gold.

"Such technical terms as "frozen muck," " pay streak," " bed rock," " white channel," are poured into my ear. I try to digest the explanations, but, alas! am very stupid so far as mining is concerned. I fear that the knowledge which my good friends possess will not pan ont well in my case.

We left in the car to see the dredgers at work, and from the distance the appearance of the busy streams from the giant nozzles suggested that the mountain was trimmed with huge waving ostrich plumes!

I was told that the year 1900 saw the greatest yield of gold, it amounting to $275,000 \cdot 00$ dollars. The following year the total was $17,368,000 \cdot 00$ dollars. Then the amount gradually lessened until, in 1914, the year of the opening of the Great War, the yield was only $5,301,497 \cdot 26$ dollars, according to statistics. Whiskey Hill and Paradise Hill are pointed out, and it is easy to imagine the thousands of stampeders distributed over these many creeks. But the pan mining of those days seems markedly primitive compared with the expensive scientific methods of to-day. We return to Bear Creek to go over the establishment of the Canadian Klondike Mining Co., where Mr. Blankman has kindly offered us hospitality and permission to inspect a dredger. Bear Creek has quite a small colony of neat houses, painted brown with white "facings," as well as the inevitable log-cabin. After visiting Mrs. J. W. Boyle at her cottage, Mr. Blankman invited us to luncheon in the huge hall, where hundreds of men are 
served. Miners will not work where the "grub" is stingy, therefore one need not hesitate in partaking of a meal at a mine. China and glass may be lacking, but there will be ample good food; the men who work in the open air in this exhilarating climate do not need appetizers. Here we have soup, huge dishes of beef-steak, a couple of roasts, a glorified stew, potatoes and two green vegetables, pudding, and pie. For beverages, there are big cups of coffee, and water. If they crave " booze," as they call it, they must " hike" to Dawson. After lunch we went to the Assay Office, and were shown long tins of many varieties of gold, some fine as dust, then the coarser. Some tins were full of nuggets ; then there were wet cocoanut-mats, which catch the gold-many thousands of dollars' worth were in that little office. One could almost wallow in the gold; it was jolly and novel to dip one's hand in the tin and pick out handfuls of nuggets, no two alike or of the same formation, each fashioned differently by Nature, just as are human beings.

Mr. Harold Blankman, who is now making such a success of the Canadian Klondike Mining Co., explained every detail in connection with the ore. It was most arresting, and I sometimes wish I had made something more than a mental note of the valuable information afforded me. Time, the enemy, called, and we motored over to the dredgers. These are enormous, and cost anything up to half a million dollars, possibly more. They resemble nothing so much as huge houses, grey in colour, with white window-sashes and rail. ings, and range in height from two and three stories to five. The housing is practically a shell, designed to protect this gigantic machinery. Woe betide anyone who gets in the way of these heavy automatically driven wonders! Our first visit was to Canadian Dredgers No. 3 and No. 4, manufactured by Marion Steam Shovel Co., of Marion, Ohio. Dredging has greatly benefited the mining industry of the Yukon, and has been proved highly profitable and successful in every way, not only in the beds and on the bars of rivers, but also on the frozen placer creek claims in the Klondike. This dredger, looking like a tenement-house, was lying in the 
creek apparently endeavouring to eat up all the earth that lay around. The hugeness and power of the monster was rather terrifying. A long travelling crane or bridge reached out into the muddy, slushy gravel, and we made our entrance on this. Here, one has to obey and move when told to. We stood beside that ever-revolving chain of sixty-eight buckets, each great receptacle full of earth, gravel, stones, and sloppy with water. Never a pause was there; on they glide, unresistingly, two gigantic cable chains on either side. The bucket-line is the most important and expensive feature of a dredge, both as regards initial cost and subsequent maintenance. The length of life of the average bucket is about 600 days. Both high carbon steel and manganese steel are used in their construction. The lip of the bucket is $2 \frac{3}{4}$ inches in thickness. Imagine, then, this never-ending line of buckets and the continual dumping of the gravel. They told me that 15,000 cubic yards of earth are dumped in twenty-four hours; also, that No. 4 dredge ran last year eleven months and three days with the temperature sometimes $50^{\circ}$ below zero. The weight of steel spud is 62,000 pounds. The capacity of these buckets is 17 cubic feet; their weight, 4,600 pounds each. We go out on the different decks or roofs, and can scarcely stand, so marked is the swaying motion. At the back of the dredge are mountains of tailings, looking dead and ghostly. $\mathrm{Up}$ in the winch-room it was fascinating to watch the workings of the machinery below-the rhythmic evolutions of the buckets, and the mighty power of the winches which controlled them. The gold is caught in the sluice-boxes on sulphided cocoanut-mats about an inch thick, the gold-dust and small nuggets clinging to the mats and expanded iron riffles. A general clean-up takes place whenever the angle iron riffles become filled to such an extent as would in any way interfere with the recovery of the gold. In consequence, the periods for cleaning-up occur sometimes once a week, sometimes twice a month. After the material gold collected on the mats has been run through the " long-Tom," they are rolled up and taken to the clean-up room at the camp, where they are washed, the gold panned and blown, after which it 


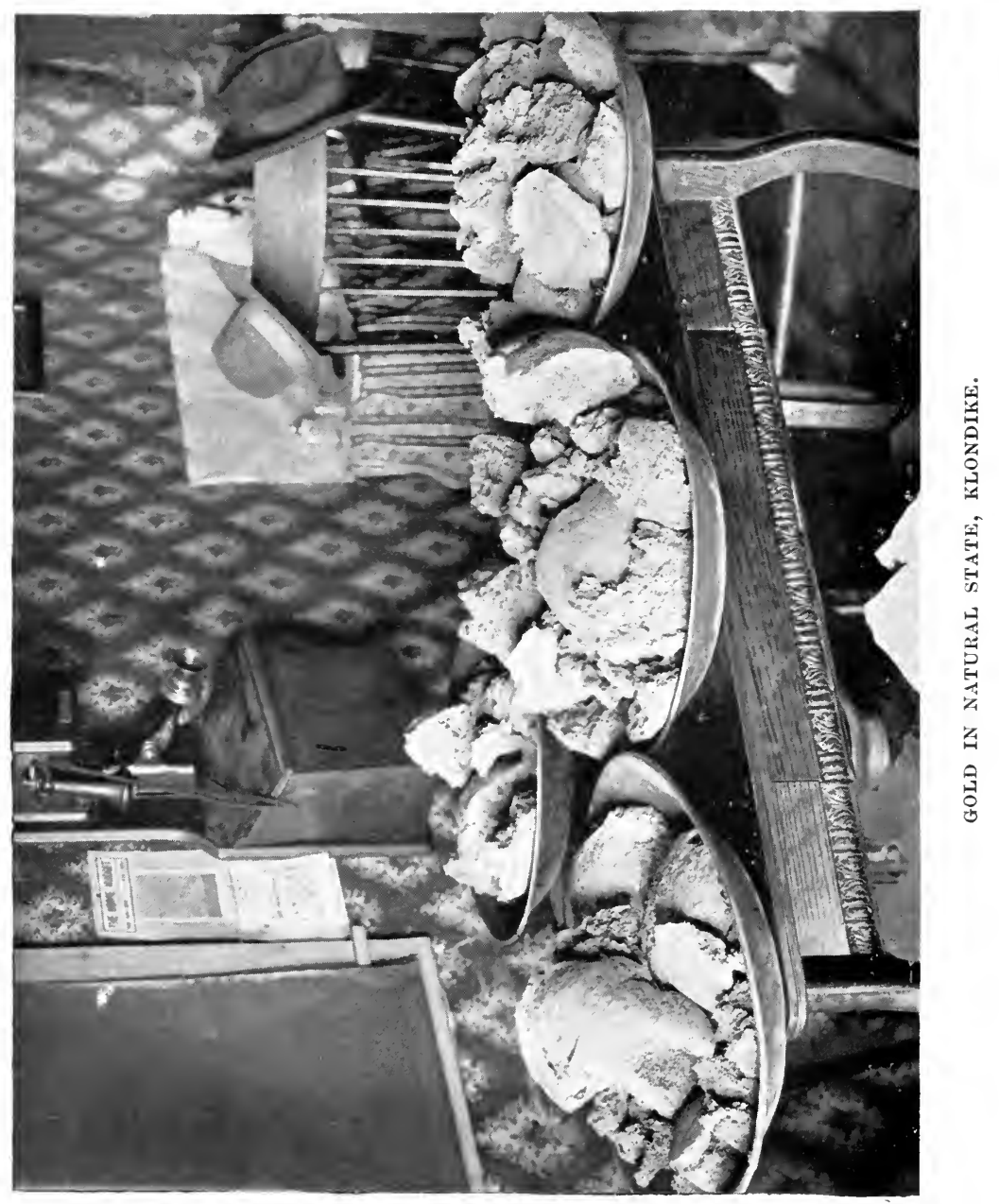

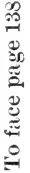



is fashioned into small bricks for shipment to the Canadian Mint. It must be remembered that all this gravel ground is eternally frozen, and that the process of thawing by forced steam is a costly one. The thaw is effected by means of steam points driven into bed rock preparatory to drilling. A far cheaper system is the cold water and pressure thawing, a new discovery which reduces the thawing by one half, and will bring many more miles of low-grade properties in this district into profitable operating range. It is already known that 100 miles of dredging ground remain to be worked in the vicinity of Dawson. The cold water discovery may make workable twice or three times that mileage of low-grade properties here. Otherwise these properties might never have been touched. It will also afford to every gold camp in the frozen gravel of Alaska, as well as the Yukon, similar increased acreage and prolonged life. The Guggenheim Companies, one of the most powerful groups in the district, and owners of the richest copper mines in the world, anticipate great results from the operation of the cold water thawing system.

Wages average, for common labourers, 4.50 dollars a day, with board and lodging, up to 8 dollars ; foremen receive from 8 dollars to 10 dollars a day, all found. Well-thought-out means have been devised for the safe carriage of gold bullion from Dawson. Large steel safes of special design have been constructed for the conveyance of such shipments to their destination, eliminating, so far as is humanly possible, the likelihood of robbery en route. Rates on bullion are: Dawson to Vancouver or Seattle, 4 dollars per 1,000 dollars; Dawson to San Francisco, 4.50 dollars per 1,000 dollars. These rates cover marine risks and losses of any nature, war risk excepted. To afford an adequate idea of this Klondike, from simple pan-washer, the rocker, hydraulics, and dredges, would fill volumes. We stopped at a road-house, kept by a German (a decent one, they said), and partook of an excellent dinner, cooked by the wife of the proprietor. We had real cream, not the "carnation" brand which one usually meets with, and home-made golden butter, strawberries and cream. 
Native productions, they were beyond anything one could have expected away up here in the North. Senator and Mrs. Heckman also joined us, with some friends. After this satisfactory repast, we again started on our mine inspection. We were going up a rather steep hill, when suddenly the car refused to budge. Charley Black adopted all sorts of devices to coax our lifeless engine. When he got out to trace the trouble, to his amazement he found we had not a drop of petrol-they call it gasolene-left. And the nearest place where we might replenish was three miles away! This would take some time to reach on foot, apart from the exertion. Each was planning how best to get out of the difficulty when great good luck sent the Senator and his car along. The Senator could not spare us petrol, but it was an easy matter to rush Mr. Black over those three long unwalkable miles to purchase a supply. Time passed; we were picking some lovely wild-flowers at a spot where a tragedy had occurred only a few Sundays previously. An overturned car had crashed down that hill into the creek below, pinning a lady beneath it. The unfortunate woman was drowned in that tiny creek in the sight of her husband, two friends, and her four children. Nothing could be done until assistance arrived.

In a few minutes Mr. Black returned, having secured an ample supply of "l'essence." Our car had hardly got on the move when, hearing cries, we turned, and discovered the Senator's car held in the grip of a sort of quicksand. Here was trouble indeed. Everyone pushed, our motor pulled, and still the car remained firmly engulfed. Looking down that hill we observed a teamster with two strong horses coming slowly along. Here, again, old methods conquered the new, for it did not take long for the sturdy horses to extricate the car. Subsequently everything went splendidly, and we all thanked Mr. John Black for a wellnigh perfect day. Mr. Black is a born courtier, with that old-time grace and a geniality which, alas! is becoming all too rare in these bustling days.

The Yukon people, as do the Atlin citizens, voice the cry: 
"Let the Canadian Government give us a railroad, linking us up with the outside world, viâ Atlin, and it will make the Yukon one of the most prosperous spots in Canada. Only give us proper transportation, and the latent mineral resources of the Yukon will not only pay Canada's War Debt, but will provide thousands of returned soldiers with comfortable and prosperous homes."

At the close of navigation, when the Yukon freezes, until sufficient snow has fallen to make good sleighing, concord coaches, drawn by six horses, are used for travelling. Ten passengers and their hand baggage are carried. As soon as sufficient snow has fallen sleighs are requisitioned, each sleigh drawn by four horses, and accommodating seventeen passengers. The maximum length of a stage is 23 miles, and fresh horses are in readiness at each station. From White Horse to Dawson there are fifteen stations, and each station has its road-house, where you take your meals and sleep. Three posts a day are made. The run between White Horse and Dawson is accomplished in five days, including a stop over every night at a road-house. It is clearly evident that the Yukon badly needs the railroad. On every side one overhears the most astounding stories of the old days. At the Alexandria Hotel, where many of us were sitting on the balcony admiring the wonderful colour effects of the semitwilight, a sourdough produced the rules of an old-time hotel, given on p. 143, which we read, and then he remarked: "Well, this hotel has seen some queer doings! A pal of mine came here for a spree, with a poke full of gold. $\mathrm{He}$ danced about with the girls, and was feeling pretty jolly. Next thing he remembered was awaking next morning with his head in a whirl. Raising himself, he looked up and observed more than a dozen empty champagne bottles ranged around him. He scratched his head in a dazed sort of way, muttering, ' I must have had a devil of a spree last night!' "' The sourdough described this as " a little way of life-saving" in vogue at the hotel. It was a frequent occurrence in those days, when a man came in from the mines loaded with gold, to drug his drink, carry him to bed, and place the empty 
bottles around him. When the victim awoke, a little bit dazed and befuddled, he had the "pleasure" of paying for this imaginary indulgence. The proprietor would pretend that the man was "no end of a sport." The victim would invariably pay up without question.

It was a "good thing" for the miner in one respect, because the man had really had a healthy night's rest, much better for him than indulgence in bad champagne. He was just as happy, and could boast about his indulgence just as if it were true. Verily, good exists everywhere, and in many an extraordinary guise! Our sourdough friend regaled us with another aspect of life in the INlondike, though he feared, in this case, the element of fiction would be very obvious. A lot of Klondikers died, and went up to Heaven. St. Peter welcomed them, saying: "Come right in, boys. I know you've had a hard time down there - scurvy, and frostbite, and other hardships." The pearly gate opened. The golden streets were visible, and the Klondikers entered. They looked all round, very much interested for a time. But soon they became bored and peevish. They met St. Peter, and said : "It's all very well, but we've got nothing to do. Give us some picks and shovels." This St. Peter did. The next morning; to his horror, he saw the Klondikers digging up the golden streets. "This won't do at all," he said to himself, so he waited for, and waylaid, the Devil. He told him how distracted he was at the conduct of those Klondikers. The Devil responded: "I'll get you out of your difficulty, Just let them know there's a stampede down in Hell." In some mysterious way this rumour circulated, and by nightfall there wasn't one Klondiker in Heaven!

When the s.s. Yukon sailed down the river, it was with a sad heart I stood waving to those on the wharf. Most of the Dawson folk were present to bid us farewell. Flowers, chocolates, and even nuggets, were my portion; and when they shouted, superfluously, "Don't forget us l" I knew I never could. 


\section{SOURDOUGH HOTEL,}

1333 Iorcle Avende.

Best House north of Mexico. First-class in Every Particular. Rates: One Ounce per day.

Crap, Chuck, Luck, Stud Poker, and Black Jack Games run by the Management.

Private Entrance for Ladies by Ladder in the Rear. Special Rates for Ministers and the Gambling "Perfesh."

Every known Fluid-Water excepted-for Sale at the Bar.

Dogs Bought and Sold. Insect Powder for Sale at the Bar. Indians and Niggers charged Double.

Not responsible for diamonds, bicycles, or other valuables kept under the pillows; they should be deposited in the safe. If you are fond of athletics, and like good jumping, lift the mattress and see the bed spring.

Towels changed weekly.

\section{House Rules.}

Dogs not allowed in the bunks.

Candles and Hot Water charged extra.

Board 2.00 dollars per square foot. Meals extra.

Spiked boots must be removed at night.

Guests are requested not to speak to the Dumb-Waiter.

Anyone troubled with nightmare will find a halter on the bed-post.

If the room gets too warm, open the window, and see the fire escape.

Base-ballists desiring a little practice will find a pitcher on the stand.

Don't worry about paying your Bill; the house is supported by its foundations.

The hotel is convenient to all cemeteries. Hearses for hire at 25 cents a second.

Guests wishing to do a little driving will find hammer and nails in the closet.

Guests wishing to get up without being called can have self-raising flour for supper.

If the lamp goes out, take a feather out of the pillow: that's light enough for any room. 


\section{CHAPTER XII}

\section{FROM DAWSON TO TANANA}

THe steamer Yukon is one of the largest and newest of the river boats. She is beautifully clean, white inside and out. Her glass-enclosed observation saloon shields you from the winds, as the panorama of the ever-varying Yukon unrolls itself before you. Looking towards Dawson, we see the cable ferry crossing to the opposite side. It recalls the day when the Senator and our party crossed and visited the numerous fox farms in the locality; it recalled also a progressive farmer who explained to us the advantages of silo, and showed us his land, which he guarded preciously, as gold had been found in small quantities near his well. All these Northerners live in hopeful anticipation that at any moment they may possess a Bonanza of their own.

The entire country is frozen eternally, and everyone has a natural ice-box wherein to "cache" his food-moose meat and caribou. Even in the torrid days of summer, if one digs from $1_{2} \frac{1}{2}$ to 2 feet one strikes a stratum of frozen earth. Yet the flowers bloom as happily from this icy bed as they do under more normal conditions. Coming down the river, St. Mary's Hospital and the picturesque church stand out boldly from the shadow of the time-scarred Dome. We soon drift past the Indian village of Moosehide, where Chief Silas is passing the sunset of his life with his people. Farther along is what they call " the shipyard," four or five river boats tied up and out of commission. It is late in the afternoon as we drift down-stream, and no one can fail to be impressed with the scenic beauties of this wonderful country-the spruceclad mountains, projecting bulwarks of rock, innumerable small islands and backwaters, the shores lined with pussywillows, alders, and wild waving grasses, and the dazzling, 
ever-glowing sunshine producing chequers of light and shade. In the sky clouds of purple-pinks and turquoise rest lightly on mountain-tops. The serpent's trail of the Yukon we follow; now it resembles a lake with islands, then again it narrows down into a deep, dark fjord, but never losing its ever-present enchantment. The Yukon does not suggest the Nile, except in the colour of its mud water and sand-banks, but somehow one's thoughts recall the Nile whilst en route.

Our passenger list is large and representative. A large number are miners and prospectors, grub-stake mushers. The word " musher" was originated by the French Canadians, from the very marcher, to walk. A grub-stalker is a man who has his supplies found him. He mushes over the lone, far-distant creeks and trails, always on the lookout for the hard, glittering nuggets ; and if successful, he has to share his find with the partner who grub-staked him. To grubstake a man in these days, his outfit alone would cost quite 1,200 dollars. Many a miner spends all he has when going into towns like Seattle for the winter. In the spring he returns " broke," and someone finances him. One of these men told me that he had visited, before leaving on his speculative tour, a friend in Seattle who had a beautiful home and a fortune. The man of wealth, who had been an old " ninetyeighter," sat on his flower-laden piazza, rubbed his hands together thoughtfully, and, turning, whispered to his departing guest: " Jim, I wish I'd lose the whole of my fortune, so I could just hike back and mush the country as I did in those good old days ; but don't let the wife know."

It's the fascination, the finding of the gold, the fight against Nature, the awakening of the gambler's spirit. There are many men in these regions who have the means wherewith to live " outside" - their word for Canada and the U.S.A.but they are accustomed to this freer life, where everyone knows them, and where they have their friends. They say it's lonesome for them out there, and they are glad to return.

With the exception of the Senator and his wife, and Mr. Steffin, the assiduous fur-buyer, our passengers are strangers 
to me. There are more of the mining element, and men predominate. Mr. and Mrs. Williams, of Detroit, U.S.A., with two young sons and nurse, have joined us; they are most agreeable travelling companions, cheechakos like myself. We all agree that it is brave and original to take these two boys of seven and nine on a holiday in the wilds, instead of making for the beaten track usually chosen by mothers.

All along the banks are holes where the musk-rat, otter, and beaver live. We are now in " Musk-rat Land," and to see the packs of dirty-looking skins done up methodically in bundles, one could scarcely imagine that the smart musquash coats were ever associated with these humble-looking muskrat pelts. We see, in shallow water, musk-rat homes made by themselves out of mud, sticks, and grass. The animals are partial to apples and parsnips, and with this bonne-bouche handy they become affable and are easily caught. There is always something interesting to see as we proceed. Quite a buzz of excitement as someone espies a brown bear cub looking down from a great height of unclimbable rocks. The Williams boys are all agog, for we see master bear quite plainly; some of the men regret they have not a gun handy. In a short time the boat slows down, and we pull up at the historical Fortymile. It consists of a few straggling logcabins, two general stores, barracks, road-house, a post office, and the usual bunch of Indians. There is a "wireless," therefore we are quite in touch with the outside world. Fortymile is the doyen of gold camps in the north; even as far back as 1886 the precious ore was being found; then afterwards it became the first stampede rendezvous for miners and prospectors. Coal is found near by, and, curiously enough, coal and gold are often mixed together. We lose several of our grub-stakers, who will soon start their trail into the primeval wilds. An enterprising prospector has brought with him an aeroplane engine which can be worked on a boat as well as an aeroplane. We watch him unload; he starts out in a few days, accompanied by his dogs. One feels rather sad for them, and hopes they will have luck. They were cheery, simple, not at all rough, nor addicted to bad language, 


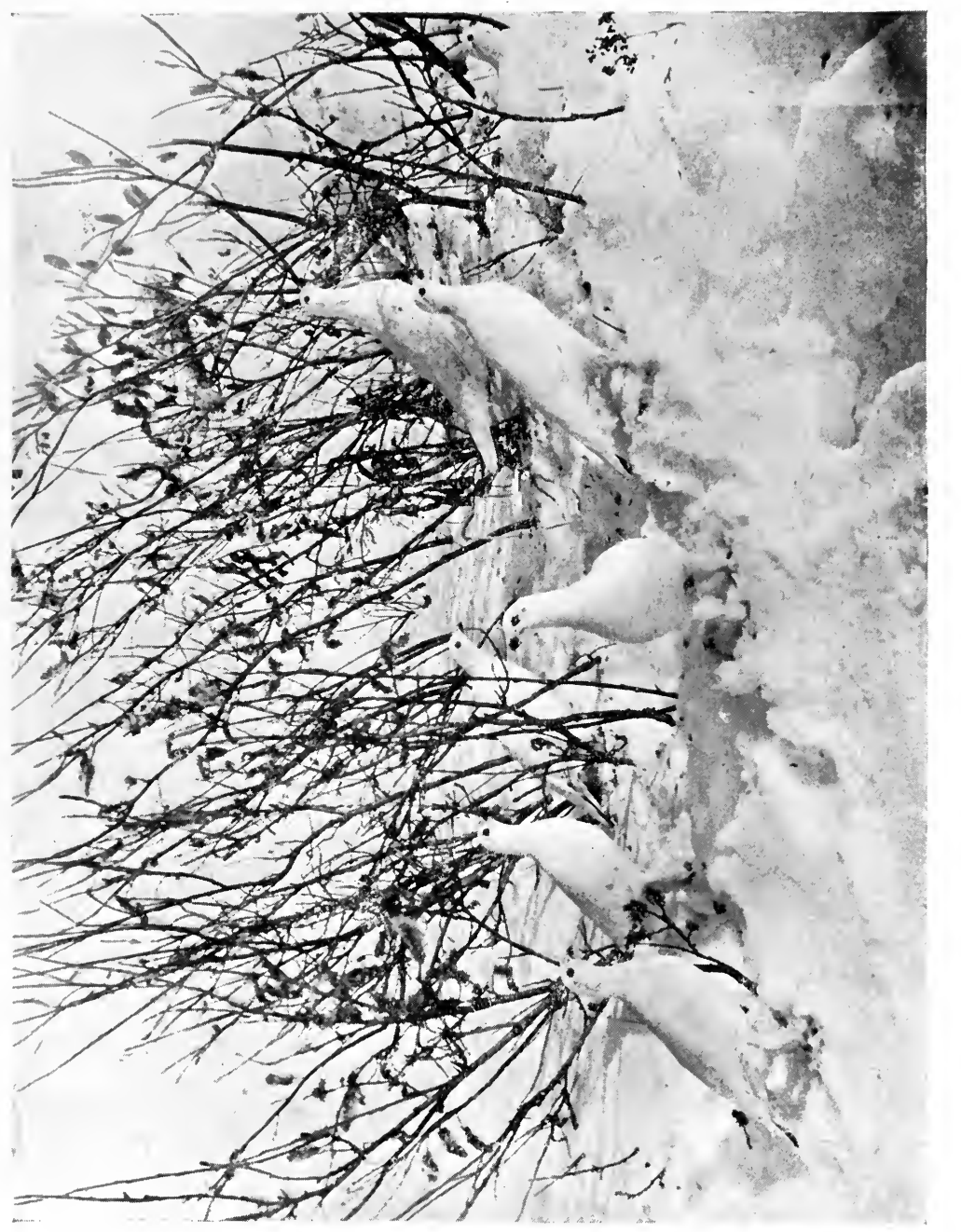

茟

跑 

as we read of in books. It is predicted that in the future most prospecting will be done by aeroplane. Fortymile was a former stronghold of the Hudson Bay Co. It was so named because it was just 40 miles from Fort Reliance. In the old days Bishop Bompas, who had spent fifty years of his life amongst the Indians, established a mission which was a godsend to the natives.

I got off the boat and walked around, but there is practically nothing to see-in fact, from the deck of the Yukon you view it all. Fortymile has had its day, and is now fast drooping towards senility. The brown water gurgles as we push away from the high mud-bank. Mrs. Heckman asked me if I was aware of the fact that rabbits (some we saw leaping on the shore) changed the colour of their coats in winter to snow white, to match the Arctic surroundings, thus better to hide themselves from their enemies. The ptarmigan also are brown in summer, but when snow enwraps the landscape these birds change their hue to correspond with Nature's covering. We glimpsed a moose peeping out of the trees. After a time either he or another swam the river ahead of us. We could plainly see his antlers until he crossed to the other side and went on his way. It is an exquisite experience to be in the heart of Nature, like this-no bother with tiresome servants, no household worries, polite attention, and excellent meals. We have crossed the boundary-line, leaving the Yukon territory behind, and now enter Alaskan waters again. We halt at Eagle, which is an American town, and where our baggage is examined. We all went ashore, and the mosquitoes welcomed us in battalions. The Stars and Stripes were gaily flying over the great rock mountain that acts as a shield or portal to this frontier town, which is prettily situated. The cabins and the few frame buildings differ very little from those of other river towns. Piles of wood are stacked on the bank, and immediately a line of wheelbarrows bearing logs for consumption on board files in and out.

At the general store, with its crowd of Indians and reeking of hides, living and dead, heavy with tobacco-smoke you could cut with a knife, we ventured in. The storekeeper is always 
glad to see a stranger, and so would anyone be if stationed here in the wilds bordering the Arctic Circle, knowing, maybe, no more than half a dozen white men, and every story of their experiences from birth upward. To these, as to the mosquitoes, fresh blood is attractive! The store certainly possessed some fine furs, amongst them the biggest brown bear skin I had ever dreamed of. A man who had been thirty years in the country, and was now going " outside " to retire, took it along with him as a souvenir. The steamer having had a good meal of logs, we again take our place on the bosom of the Yukon. Shortly another mud-bank is passed and a simple plank put across, as there is neither pier nor dock. This place, which looks a little more desolate than the others, is called Circle. My thoughts picture this spot in winter, with the river frozen and piled high with ice.

Yet Circle had second place of importance in the bewildering stampede for gold. People poured into this raw mining town, pitched their tents, built log-cabins, to such an extent that in 1896 it was the biggest log-cabin settlement in the world, the men trading and searching all over the creeks for the metal which buys so much. Now that the rush is but exciting memory, a row of cabins, the usual store, a roadhouse, and an Indian village, are all that is left. Naturally, with people who have little otherwise to distract them, the arrival of the mail brings everyone out. It is a sight. The summer season is very short; soon there will be only the Northern Lights or aurora borealis to light their sky. A row of Indians are sitting on the bench before the one store, an entirely different type from the Indians around Ketchikan and Skagway. Of course, we have come very far north. These people are dark-complexioned, with straight, coarse black hair, and a Mongolian cast to their features, which from an ethnological point of view is interesting, and no doubt might be traced to the Russian occupation mingled with the Eskimos. These Indians gain a livelihood by trapping, curing the skins, hunting, and fishing, and they farm the dogs all summer. People will send their dogs and pay 4 dollars a month; they are fed very little, and principally upon 
salmon. On every bank you will notice the big wooden fishwheels working; these revolving wheels gather in the salmon, of which the Yukon supplies thousands. Beside the wheel on the bank is the tent or hut for the Indian and his squaw. Long, wide strips of salmon look like red flannel shirts would on the lines ; from the distance you wonder what all that redcoloured stuff is gleaming between the green trees. As you come nearer, you see the big strips of salmon being dried, food for the dogs-the horses of the Arctic-during the winter. In summer they lead a dog's life in very truth. They are obviously bored and miserable, on account of their heavy coats, and the ceaseless attacks of mosquitoes and big fliesand they naturally howl about it. At Circle the Northern Commercial Co. have the first link in their chain of trading stores which one meets with all over Alaska. McQuesten was the first trader sent by this big concern to establish this post. In leaving Circle, dead, dreary, and deserted, it was hard to imagine that in the gold days 3,000 people lived at this melancholy settlement.

We pass on, and now enter upon the Yukon Flats. The river widens, the shores become distant; trees, $\log s$, and all sorts of wooden wreckage float down-stream, for the river undermines the shore, and many a tall spruce and fir falls into the river and floats on to the Bering Sea. These flats are some 200 miles in extent. There are many treacherous spots-islands and banks-therefore the boat proceeds slowly and cautiously, for the channel is constantly changing.

There is a sense of unquestioning honesty amongst these Northerners. I remarked at Dawson that Mrs. Mackenzie never locked her house when she went out, and when I questioned her she replied: "Oh, we never think of such a thing in this country; no one ever locks a door." My mind went back to London instantly, and I wondered what would be the fate of our household goods if we followed her example. Now, a pioneer lady tells me that she has often remained for days alone in her cabin, with 20,000 and 30,000 dollars' worth of gold in sacks under her bed. She never even thought of robbery, though her husband would be mining away up the 
creeks. One who did anything mean or dishonest, she said, was handled roughly and put over the frontier. The men knew that; to steal another's poke was regarded as a crime so despicable that no one cared even to contemplate it. In the North are many cabins scattered all over the country, unlocked and unguarded. Now, in mushing through the snows in the terrible blinding storms, when life is almost extinct, so completely is one frozen, any sort of shelter is a veritable star of hope. The traveller enters a deserted cabin, and will find some dry wood and kindling matter sufficient to light a fire. To anything in the place he is welcome, but it is an unwritten law that when he departs he must also leave sufficient material for a fire for the weary traveller who may follow him. If he is such a cad or so thoughtless as not to comply with this recognized code of the Yukon, his life will be rendered miserable until he quits the country.

They expect clean, straight men up here, men who play the game, and woe be to those who do not! The gates are few and well watched, either in leaving or coming into this frozen zone.

Life is exceedingly restful as one lies back in these comfortable rattan chairs. It is midnight, yet the sun blazesa phantasmagoria of chromatic wonders. That dazzling orb of crimson and gold, so far away, dips the horizon, skims the brim, and voilà! Aurora is reborn in all her pristine beauty. Slowly she again mounts the sky-line, irradiating all with glories of colour. Words are hopeless to convey the compelling beauty of the Midnight Sun as one rushes swiftly down the Yukon. River.

Right up in the Arctic Circle lies Fort Yukon, our next place of call. The river is broad, the lands more flat, and covered with scrub spruce. The Porcupine River joins the Yukon 3 miles above this village, which is purely a native settlement. Some 150 Indians live here, and the number is greatly increased for the winter season. Historically speaking, Fort Yukon is interesting, insomuch as it is the oldest trading post of the Hudson Bay Co. It dates from 1846, although the Russians were established at Nulato, farther 


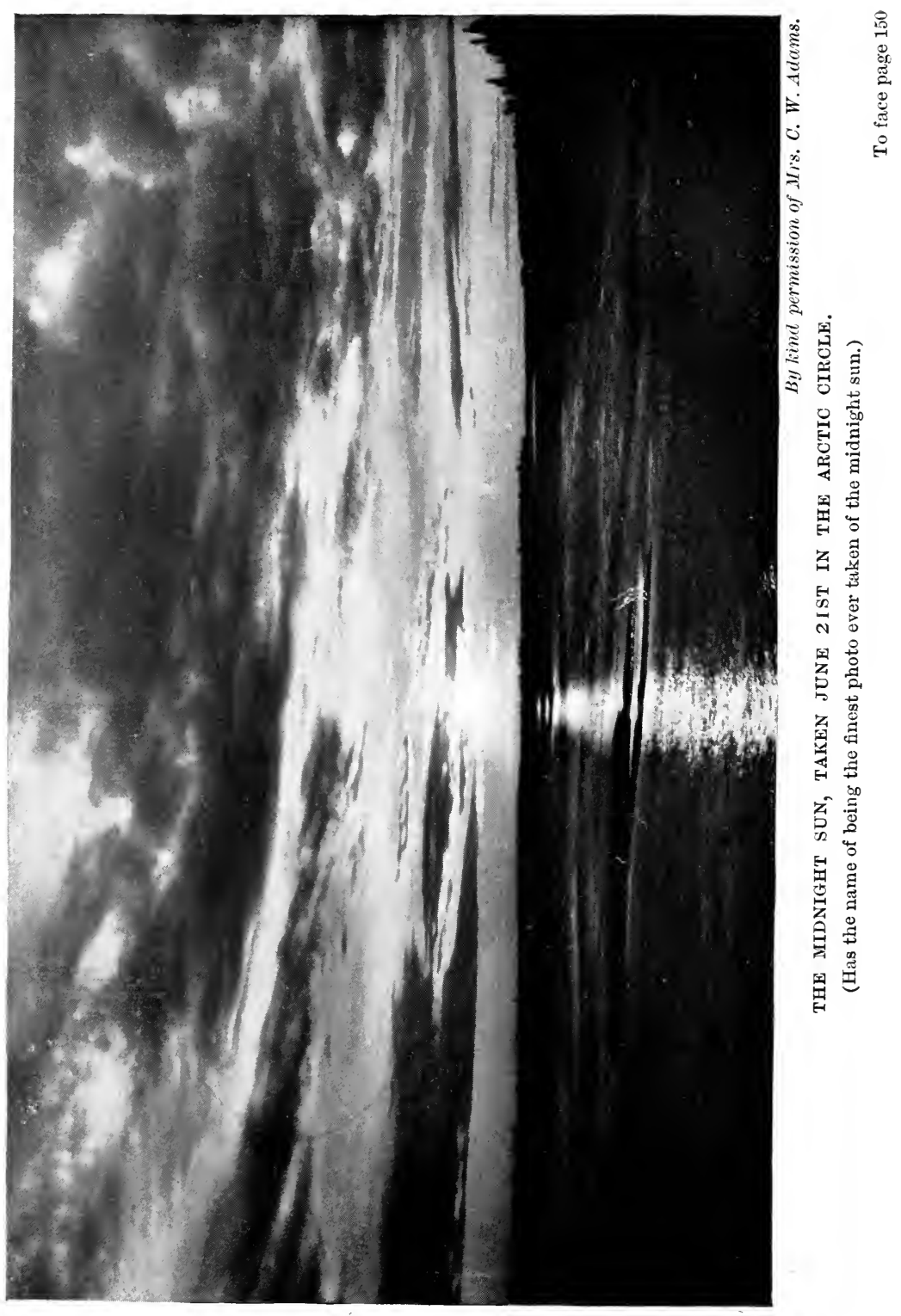



down the river, before that date. It has the distinction of possessing the oldest cemetery, the first record of white men's graves in the country. Here in 1862 Archdeacon McDonald, with his Indian wife, created the first missionary station, and noble work he accomplished. He was the first white man to give the natives a better idea of life; the Word of God was preached and the evils of "hootch," or bad whisky, expounded. The Archdeacon translated the whole of the Bible and the Book of Common Prayer into the Indian language. These translations are used to-day by Christian Indians all over the country. This worthy missionary of the Church of England did much to advance civilization in the North, and his name is revered by every Indian. Fort Yukon is the great meeting-place for the natives for miles around. It is their capital, the venue of many a great pow-wow. As a fort it is abandoned, but fifty years ago a log block-house helped to maintain peace amongst the Indians. The river-front for about a mile has a line of log-cabins, a road-house, wireless, and various trading stores. The post office is quite imposing for so small a place. I went into a store to see the furs, but unfortunately most of the pelts were packed for export. There were many Indians about, cleaner and more selfrespecting than in many of the places at which we had stopped. Here was a better class entirely, probably due to the good work of the mission. Trapping is their chief means of livelihood. The women make excellent bead-work. I noticed the wide bands of beads, beautifully blended and fringed, with which the young squaw binds her papoose to her back. They described this work to me as " athabaska." They also make very elaborate moccasins, and long, muchbeaded gauntlet gloves. The chief, John Henry, to whom I was presented, looked about a hundred years old, and seemed very happy.

I visited an Indian log-cabin; the squaw was quite pretty, and obviously had a lot of white blood in her veins. Her place was clean and nicely kept. In her living-room was a white enamelled bedstead, in the centre of which sat a baby with red cheeks, jet-black hair, and big dark eyes, who imme- 
diately began to howl at sight of me. The adult Indians greeted me with smiles, and appeared most happy and friendly, all speaking good English, they having attended the mission school. Bishop Rowe, the Bishop of all Alaska, and Archdeacon Stuck, an obvious Britisher, met us, and conducted us through the mission hospital, and also to St. Stephen's Church. This hospital is well built of spruce logs, but almost too near the mud-bank of the Yukon for safety. As the bank yields at times to the swirling waters, it would be a catastrophe were the hospital to be washed down-stream. With its pretty white-curtained windows and flowers in pots, this long one-storied log hospital, situated on the Arctic Circle, is unique of its kind. Imagine these good sisters or nurses devoting their life to this work of relief, away up here in the wilds, enduring the hard, cruel winters, in order to mitigate the suffering of the poor Indians. Is it not noble of them? Bishop Rowe, who is beloved by every soul, white or Indian, in the North, explained the different features of the building. He remarked as he nodded to an old woman, his kindly face illumined, " Only yesterday this poor woman was found suffering under a tree, some miles away. She said she was going to die, so they brought her to the hospital, and now she lies on a clean white cot, recovering." One must have a feeling of intense gratitude to and respect for these Christian workers who, by self-renunciation, perseverance, and charity, care for the natives, teaching them cleanliness, godliness, and pointing the way to heaven. Bishop Rowe never tires in his work of rescue. One glance at his face, and you read therein the grand character of the man. The hospital and St. Stephen's Episcopalian Church are supported by voluntary contributions. Should there be a philanthropist desirous of affording real benefit to humanity, a donation to the mission to these poor Northern Indians would be well expended.

That great explorer Vilhjalmur Stefansson, who knows his Arctic and the Eskimos as no man does, arrived here this spring by dog-team straight from the Arctic Ocean, where he had spent three years. He was very ill, and stayed at the hospital several months recovering his health. We visited 
the quaint, artistic log-church of St. Stephen's. Its interior was primitive, yet the simplicity was pleasing. On the logwall in the Indian language was this motto, " Praise ye the Lord." Over the altar hung a well-executed painting of our Saviour on the cross. The church cloth was especially remarkable, a splendid specimen of the Indian woman's work. The foundation was white buckskin bleached to snowy whiteness and as soft as velvet. It was deeply fringed; down the sides were wide bands of solid fine bead-work, in nicely coloured designs emblematic of the Church; in the centre a large disc of pure white beads, bearing the letters "I.H.S." It was indeed a beautiful and artistic piece of work. According to the fashion here, everyone came to the bank to see us off, as did a large number of dogs, including malamute and the. Indian Siwash dogs. The boatmen threw them a lot of broken food, to their evident delight. Thus, everyone is made happy by the arrival of the Yukon boat. One's heart yearns with pity for this handful of humanity hidden away in the North. They may well call this "a Faith, Hope, and Charity country"!

Again embarking, we pause at Beaver, where some of our prospectors land to take the portage trail to Coldfoot, Bettles, and beyond. An interesting sight is the sloping, cultivated fields of the Government Experimental Farm at Rampart. This appears to be in a flourishing condition; one would never believe that grain and all kinds of vegetables could be successfully cultivated only a few hours down-stream from the Arctic Circle. Rampart is much the same as other villages. Everyone lands and walks around to see the red-roofed cabin where Rex Beach lived for some time, and here gained the local colour for his interesting narratives. The imp of the Yukon, as if tired of flats, now shoots us through the ramparts. Again we have huge, high walls of rock, canyons enclosing glacial waterfalls, and high bluffs trimmed with spruce. Another turn, and we are surprised to see Tanana, and at the farther end Fort Gibbon with its chrome-yellow buildings. Tanana is a sort of Alaskan Charing Cross, the junction where one changes for St. Michael and Fairbanks. Fortu- 
nately, I have not to leave this comfortable steamer, as on this voyage she is heavily loaded with freight for Fairbanks. In travelling in the Northland, and especially this season, one has to take one's chance in securing transport. There are not sufficient passengers to guarantee the expense of running a number of boats, as only a few prospectors and men engaged in business come this way. Sadly enough, people are leaving the country in far greater numbers than is counterbalanced by new arrivals. There are no "stampedes" on ; the cost of living and freight is ever increasing, and people are migrating "outside," until the country is opened up by the railway or gold is again discovered.

The excursion trip from Skagway-the "Midnight Sunners "-organized by the White Pass and Yukon Co., takes the people as far as Fort Yukon and then back over the same route. Travel is not expected to be quite so well planned from now on. From Tanana to St. Michael the boats are of a different class; older and built more or less for unexacting mining people. Undoubtedly, as prospectors and geological experts declare, there are yet vast stores of minerals in these unfrequented lands, treasures which old Mother Earth still elects to hide. Tanana, a trifle more imposing than other towns, has several modern buildings besides the usual log-cabins; two hotels (one closed) and several saloon bars, reminiscent of other days, now transformed into icecream soda parlours; two churches, Catholic and Protestant ; a butcher's shop, and two or three general stores. It has, moreover, quite a reputation for furs. All these buildings are situated on the main front street, which ends at the Fort Gibbon Barracks. The cost of return passage from Tanana to Fairbanks is 53.45 dollars, a war tax of 8 per cent. being levied for all travelling in the U.S.A., while in Canada the voyager only pays 1 per cent. on the ticket.

It is with regret that I bid au revoir to Senator and Mrs. Heckman as they disembark to await the St. Michael boat. "No one can prophesy what day she may arrive. She's down the river somewhere taking on tinned salmon, and when 
she gets here her boilers have to be inspected and cleaned before she can again go down-stream." This is the indefinite official answer you receive to your inquiries. Tanana has an evil reputation amongst travellers because of its waiting list. It is the place where you may be stranded for a week or a month with nothing whatever to interest you. All travellers. dread Tanana. The Heckmans I shall meet later on at Nome. I remain on board, and go down the Tanana River to Fairbanks, some 275 miles. After seeing the largest town in these parts, I again come back to Tanana, and await a boat to St. Michael. One has to guard face and hands with the mosquito-veils, for here we encounter a new, ferocious, and malignant species of mosquito. Everyone keeps their bag-like net well pulled down over their head and arms, otherwise life would be insupportable. We now take on an immense barge, almost loaded to the water-line with merchandise, mainly canned foods and provisions, food for the Fairbanks people during their long winters. The season is short, consequently all their requirements must, until the railway is opened, arrive through this long waterway. As the steamers are back-wheelers, we must push the barge ahead of us, this naturally retarding our progress. They tell me that on occasions three and four of these huge barges are pushed ahead of the boat. We arrive at these different towns at the most extraordinary hours. It was so at Beaver, Eagle, and other places. It is now 1.30 a.m., but with this continual daylight the otherwise " unearthly" hour is of no consequence. I cannot say when the natives sleep, but they always meet us on arrival, and all the stores are in full blast at these weird, unnatural hours. Our boat slides away down the Tanana River, which looks exactly as the Yukon did, only we don't seem by any means so smart, now that we have to push that cumbersome, ugly barge in front of our nice white boat. From being a pleasure craft, we are now transformed into a trading vessel. Our last glimpse, as Tanana faded in the distance, was of our pleasant fellow-voyagers vigorously waving handkerchiefs. We were rather undecided as to whether these were signals of farewell or indicated a united onslaught on the bloodthirsty mosquitoes! 


\section{CHAPTER XIII}

\section{UP THE TANANA RIVER-HOT SPRINGS AND NENANA}

THE Yukon proceeds slowly up the Tanana River, pushing forward that heavy barge heaped high with merchandise. Life on board would be perfect were it not for the frequent delays at the banks necessitated by the taking on of logs. We lay alongside for an hour or more, the sun blazing down, and find ourselves at the mercy of the mosquitoes and another new arrival in the shape of the big, lazy, clumsy moosefly. I have hung a netting over my open cabin door, and these stupid moose-flies gather in dozens and cling to the net. I try to write, then grow annoyed and nervous at this attempted invasion. Murder whispers in my ear, and I commence a bout of extermination which is extremely disagreeable on both sides. The invaders make a quick entry into Kingdom Come, whilst I grow hot with the exertion and the disposing of the corpses. One of the small Williams boys is earning 5 cents for every twenty-five flies destroyed, and if they continue as plentiful all the way up to Fairbanks, this bright lad will amass considerable pocket-money. It is very warm as we progress up-stream. The sun beats upon the placid waters; the hills and mountains retain the heat, although 2 or 3 feet below the surface the earth remains ever frozen. The evenings are glorious ; the boat turns and twists, ever following the tortuous passage. Some nights the whole horizon is on fire, burning furiously, then it fades into all sorts of yellows, pale and otherwise. Again Nature has recourse to her palette, and paints the sky with blush-rose pink, dots it with fleecy clonds of opal. One watches these wonderful changes with spellbound fascination, losing all thought of time in beholding the grandeurs of the heavens. The river 


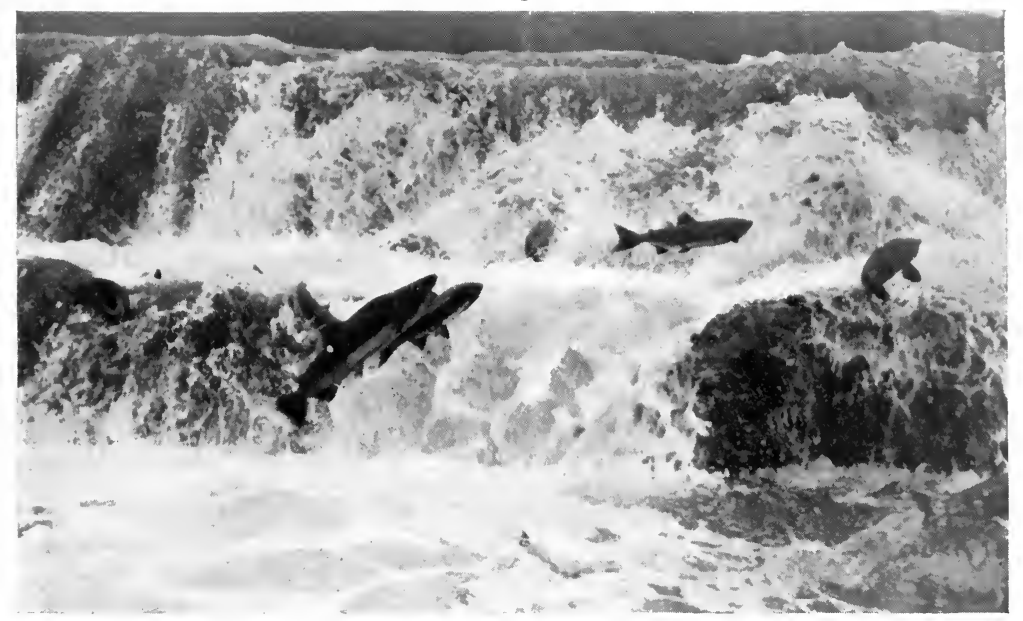

SALMON GOING BACK TO THEIR OLD HOME TO SPAWN AND DIE.

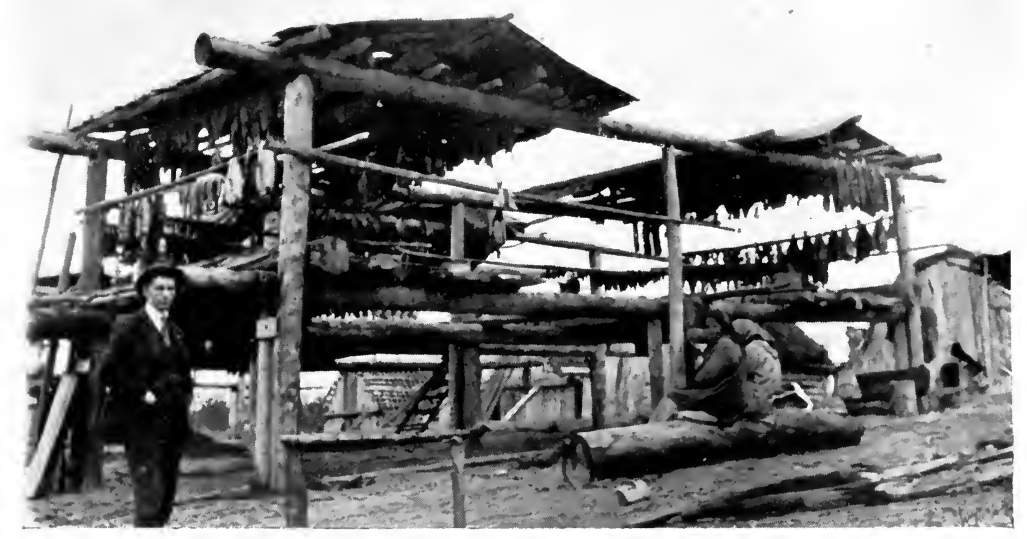

STRIPS OF SALMON BEING DRIED : YUKON RIVER, 

narrows, and we stop for the night at Hot Springs, which has quite a reputation for the medicinal and curative properties of its waters. It is a pretty village resembling a Norway port; the cabins have roofs of earth in which wild-flowers are blooming-roof-gardens in very truth. Formerly there was a large hotel here, which, according to rumour, cost 120,000 dollars. It was a blessing to people, obliged to pass the winter in this frozen zone, to discover a spot where boiling water obligingly gushed out of the icy earth. The baths connected with the hotel were regarded as excellent for the cure of rheumatism. Unfortunately, a fire destroyed the hotel, but the proprietors are hopeful that soon another will be built on its site.

A party of us ventured out for a walk, but, not knowing the way, we stumbled into a bog of this hot mud. I sank up to my knees in the oozy mass, and had to be pulled out by two strapping Alaskans, after which, caked with mud, we beat an ignominious retreat to the boat. Continuing up-river next morning, we pass more Indian camps and salmon fishing wheels. You hear a rustling, and on looking at the wheel you will see a big salmon fighting, wriggling, doing all it can to slip back into the water; but his efforts are in vain, and down he goes into the box on the bottom of the raft, and finds himself in the glittering company of his fellow-prisoners. Sometimes a single wheel will catch as many as 500 salmon in a day. Salmon is the staple food both for the Indians and the dogs throughout the year, and especially in the winter. Its abundance is most certainly a boon to Alaska. All down the Yukon and Tanana Rivers you will find salmon on the menu every day, and, indeed, there is nothing finer than the big " King Salmon," the meat of which is almost red and very rich in oil. The boat people pay the Indians 10 cents a pound for it. In winter they mix a low grade of rice with the dried salmon for the huskies; rice, they say, is as cheap as anything else, and the dogs require plenty of food, or they cannot haul their loads in weather ranging anywhere from 40 degrees below zero to 70 degrees. You can tell when you are approaching these fish-camps by the stench and the flies. 
We now draw up beside a camp and a wood pile of 500 cords. We require a much larger quantity of logs on the journey upriver. Going down with the current, a cord an hour will suffice for the furnace. But in going against the current four or five times that amount of fuel is essential. The cost, by the way, averages 8 dollars a cord. Can one imagine a life more lonely than that of a wood-chopper in these wilds? Many a man who had hoped to forget the past in the world's solitudes has buried himself in these forests, and earned his livelihood in these dreary, vast spaces with no one to speak to other than his dogs-most of them have one or more-or maybe a squaw. Alone in their cabins, they fitly illustrate " the world forgetting, by the world forgot." One of these wood-choppers is looking at us rather sadly now, and I wonder what his life has been. There are about two dozen dogs boarded at this camp, and very miserable they look, tied alongside the river-bank at equal distances apart, so that they cannot fight. They are in the main malamutes. Each has dug a hole for himself, and curled up in these holes with just his head protruding. They form a peculiar picture ranged in their individual dug-outs, until you get used to it. They are sensible and practical; they hate the heat; burdened as they are with their heavy fur coats, they detest no less cordially the moose-fly and mosquitoes, and are more protected in their cool dug-out. The average malamute gets a salmon for his meals every other day. There is no aim in their existence in summer ; in winter they are man's all-in-all. They carry the mail, and run races which are even chronicled in the outside world. But in summer they dig their holes near the water's edge and sit there and think. The Indians charge 16 shillings a month to board a malamute. This Indian camp is rather a superior one, inasmuch as the residents have made their clearing quite neat; the cabin, tents, and vegetable gardens are well kept, and suggest system and order. We wandered about under the long red strips of salmon drying in the sun. The huskies howled as we passed; others eyed us sleepily, too lazy to utter a sound. We look into the revolving fish-wheel, and the box is nearly full of 
silvery salmon. A whistle from the Yukon and we again embark. These Williams boys are having the time of their lives; curious stories will they relate to their boy-friends in Detroit. The sourdoughs like nothing better than taking them ashore and explaining things. Again, for miles and miles, the vast landscape unfolds, like an unending movingpicture reel. Democracy rules in this part of the world. There are no classes; everyone belongs to the same circle. Tips are a source of endless embarrassment. You have to bestow them discriminately, because they are too proud to accept an ordinary tip. When you decide to offer a gratuity, you tentatively say, "Have some cigars?" Then you place your money down quickly and turn away, or you change the conversation. It is awkward at times to know what to do. In this country the man who waits upon you may own a mine, may have been very wealthy; next year he may not impossibly strike gold again and be travelling first class round the world, a favourite of Fortunatus. Who knows? Then, there being no social grades, they all know the best and the worst of each other. The long frozen winters impose upon them a real brotherhood, and a mutual bond is established, more enduring than in any part of the globe I have visited. We stop to disembark some men and supplies at Tolovana. The men are proceeding to mines in the interior, and will travel by a small boat up the Tolovana River. To-night at sunset Mount McKinley, the highest mountain in North America, or Daneli, as the Indians call it (meaning Most High), could be clearly seen, although this colossal mountain is fully a hundred miles from us. Covered in snow, its 20,300 feet seeming to pierce the deep-blue sky, in the rosy glow it looks like a pink pearl in a mighty turquoise setting.

As we sat in a group watching the ever-changing landscape, the steward of the Yukon essayed to tell us some of his experiences. He was an old-timer, and had owned a restaurant at Nome in the days of the stampede. For a steak he charged 7 dollars, and an apple would fetch 1 dollar. Prices ran high. He also had owned a bunk-house; for these dirty bunks, ranged one above another, 5 dollars each would be 
charged per night, and they were alive with insects. " But," he added, "those miners coming in from the off trail were so darned tired they never cared a hang." He recalled having negotiated for a dead cow from a man who appeared anxious to get rid of it. Now, fresh meat was indeed a luxury in those gilded days. He was rather dubious as to how the cow had died, but it was wiser not to be too particular. He cut the cow into steaks. In came a miner, crazed with hootch. Pointing to a 7-dollar steak, he said : "Guess I'll have it ; put it in the pan, and here's my poke." He produced a dirty leather poke, flinging it at the steward, who was cook. The poke was untied; and in those days you simply weighed out the price in gold-dust, and 'returned the poke to its owner. Well, this man started a "rush" on the dead cow; many came in to eat, and in a short time not a piece remained. It must have been a wonderful cow, because, after it had been disposed of, its former owner continued to sell milk for two weeks! "Some cow that!" wound up our informant.

The next morning, upon awakening, we found ourselves alongside a very modern wharf, with a huge warehouse. The town is Nenana, primitive as yet, but rich in possibilities, because it is the connecting-link for the Government railroad now building from Seward and Anchorage. This will open up the country, and the rich coal, gold, copper, antimony, and other mines, can secure necessary transport.

This Seward, Fairbanks, Nenana Railway running through Central Alaska, connecting direct with the Tanana and Yukon Rivers, establishes a route to St. Michael and Nome to the west, and Dawson, White Horse, and Skagway on the east. Nenana is optimistic. Three years ago St. Mark's Mission was its principal source of interest. To-day it literally thrills with possibilities.

The Government have established large warehouses, a good hospital, and general offices, neat frame buildings painted dark slate colour and white. Large letterings, "U.S. Government" and "Alaskan Engineering Commission," strike a note of progressive activity. The streets are well 


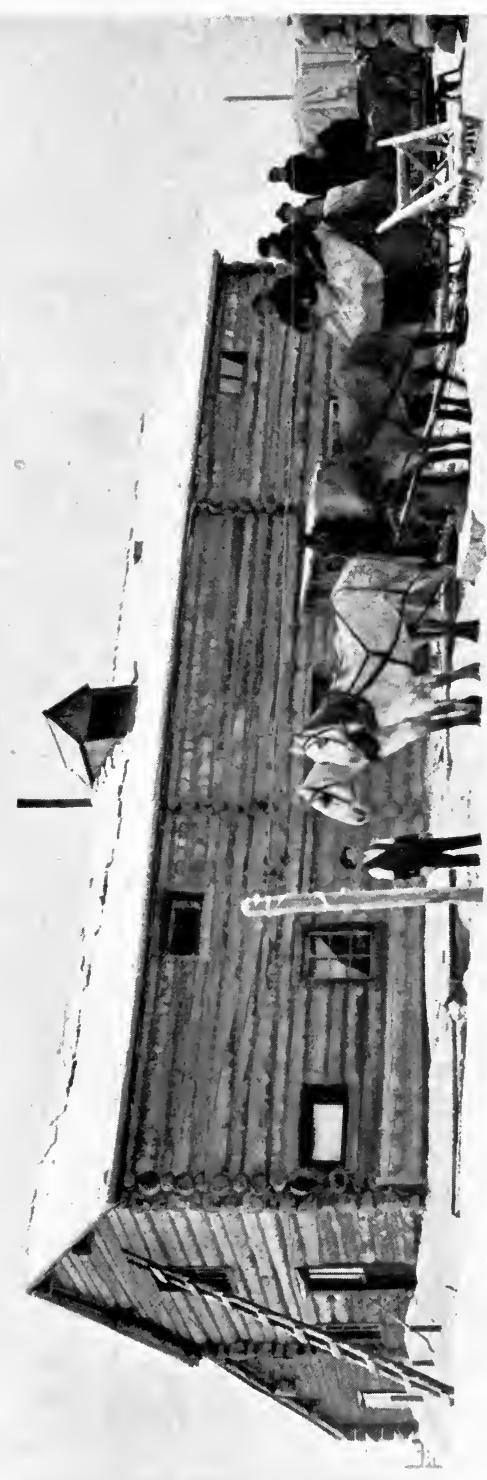

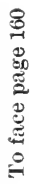

年 
<smiles>C1CCCCC1</smiles> 
laid out, and the board-walks in good repair, not like some of the "has been" neglected mining towns on the Yukon. The Government contemplate building a bridge over the Tanana River at this junction, which they hope will be completed and operating in 1921.

It is interesting to walk about this newly-born town, so prettily situated, and half-enclosed by the primeval semicircular forest of green. All the inhabitants appear to be glad to meet you. We were introduced by Mr. Nelson, a pioneer, a huge, strong Alaskan who has buffeted the cruel winters for many years ; for as he drove the mail teams he, like many another sourdough, could only be happy in that "big out-of-doors " country. He had passed the winter in Seattle, but was glad to be home.

We visited the Cooney Hotel, a nice clean, comfortable place kept by Mrs. Cooney, a pleasant-faced woman with kind eyes. She is a widow, with a son of fifteen, who by his own hard earnings has purchased a plot of land and erected a double-windowed log-cabin on his property, valued at 1,500 dollars-not a bad example of young and enterprising Alaska! All the Nenana people are sure they will be wealthy when the railway opens up the immense belt of coal in the environs. They are snapping up all the land available, and await developments. Mrs. Cooney offered to show us her "stable" of eight malamute dogs at the back of the hotel. Their joy knew no bounds when she released them, calling each by name. They are much like the wolf in colour and appearance. In this country a good dog-team is a valuable asset : to possess one is a general desire. To illustrate the kind hospitality one receives, Mrs. Cooney, who is social leader as well as proprietress of the best hotel, and Mr. Nelson began at once to plan a reception and dance for the visitors on the Yukon, to take place in the big hall that evening. They began telephoning to the citizens of Nenana to be on hand. First there was to be a cinema show, and then a ball to follow. We were surprised at the number of shops at Nenana; canned goods are much in evidence, as many mining camps in the district are supplied. Chocolate and ice-cream-soda saloons 
looked appetizing; a good millinery shop and dry goods store were passed, besides many others in the one main street. It struck us as novel to read these signs :

Silver Moon Restaurant.-Jones's Bunk-House.

A tailor's advertisement :

Perk up. Have Pep. Have your suits pressed and cleaned. Be ready for the 4 th of July, and what comes after.

Mrs. D'Orsay's is the Place.

Another :

Count thè cost; you are in Alaska, and Alaska is in your system.

Being a sort of journalist, I visited the office of "The Nenana Daily News, Where Rails and Rivers Meet." Mr. Southworth and Mr. Bell, the owners, received me with characteristic geniality. Mr. Southworth showed me the workings of his up-to-date printing plant, at the same time explaining that two men were doing a five men's job, and great credit they deserve for producing such an excellent paper at this far end of a trail. They are also members of the Associated Press. You will be surprised to find how well read these Northerners usually are. The long winters prove a stimulus to the acquirement of knowledge. I may add that the price of the newspaper in Yukon and Alaska is 25 cents, or 1 shilling a copy. In fact, one can purchase nothing at a lower price. I had a very pleasant call upon Mr. and Mrs. Brown at their charming bungalow, steam heated and entirely up to date. Mr. Brown is in charge, and represents the Government railway. $\mathrm{H}_{\theta}$ had also been an engineer engaged on that gigantic masterpiece, the Panama Canal. I having also been at Panama, it was enjoyable to talk things over. Mrs. Brown, whom everyone appeared to like, had been most active in working for the Red Cross. In the great outside world one would not imagine that these far-away towns were each doing more than " their bit." 
This is what Nenana did to help the Great War :

\begin{tabular}{|c|c|c|c|c|c|}
\hline Yarn Fund & $\cdots$ & $\cdots$ & & 2,889 & ollars \\
\hline Membership Drives & $\ldots$ & $\cdots$ & ... & 5,750 & "' \\
\hline Neuilly Bed Fund & ... & ... & . & 10,543 & ," \\
\hline Red Cross Fund & ... & ... & $\cdots$ & 1,417 & , \\
\hline War Relief ,... & ... & ... & $\cdots$ & 627 & , \\
\hline French Orphans & .. & $\cdots$ & $\cdots$ & 764 & , \\
\hline Belgian Relief & ... & $\cdots$ & $\cdots$ & 663 & ," \\
\hline Tobacco & ... & $\cdots$ & $\cdots$ & 179 & ," \\
\hline
\end{tabular}

I do not add the fractions, but over $22,836.00$ dollars were thus raised, as well as 307,176.51 for the Liberty Bond drive, War Savings, and Thrift Stamps.

Brave Nenana, with its comparative handful of people!

Needless to say, the entire population attended the ball and cinema show at the Coliseum. The streets were lined with people when we walked over to the picture-show at 8 p.m. They were all interested, and honoured us with some long stares, which we returned with interest. We, on our part, were equally anxious to see who lived at Nenana. After the pictures we adjourned to a large hall decorated with flags. Mr. Robert Divin, the Presbyterian clergyman, mounted the platform, and in a cheery, friendly address said we were to regard ourselves as already introduced, and he welcomed us as fellows of the great family of the North, and admonished us to enjoy every moment, and therefore to open the dance without further ceremony. The parson's son opened the ball, and he certainly could dance-jazz, fox-trots, nothing was too new for him. A peculiar and sensible feature in Nenana is that the minister encourages all harmless pleasure, sports of all kinds, and dancing. For instance, on Sunday evening the people attend the "movies," and afterwards go on to attend the church service. This tolerant, broad-minded spirit is refreshing. It is an attitude which might well be cultivated by larger communities. Although we were all supposed to be introduced, certain ladies acted as hostesses, bringing up people, and telling us who they were and what they had done. In all these halls in the North hangs a giltlettered list of names of pioneers who opened up the country. Mr. Nelson proudly pointed out his name amongst many 
others. Beside the ordinary one-steps, hesitation waltzes, and other dances, they introduced a Paul Jones, in the figures of which you dance with nearly everyone. Mrs. Williams, upon being swung around rather rapidly, looked up and confronted the bronze face of her steward at table! But, as I have said, the hospitality and goodwill of the people know no bounds. The ball ended at 4 a.m. Upon leaving the hall and emerging into the bright daylight, it was suggested that we should go across the road to a restaurant. There we found most of the guests sitting down to a homely breakfast of ham and eggs, sandwiches and coffee. We soon were partaking of a similar meal; everyone was merry and happy, even under the sway of prohibition. It is a weird sensation to be walking back to one's boat at these early hours. Yet everyone is out. There are no crooks or evil people in this sparsely populated land. As I was attempting to sleep a little later on, I smiled to myself as I wondered what would be the consequence were I to adopt Alaskan customs on my return to London. Imagine going to bed at 5 in the morning, having already partaken of a heavy breakfast! I can picture the righteous horror of my most respectable old housekeeper, her remonstrances, topped by the inevitable one month's notice. But Alaska and London are widely different propositions. 


\section{CHAPTER XIV}

\section{FAIRBANKS, THE GOLDEN HEART OF ALASKA}

SLOWLY the steamer Yukon, after infinite windings and turnings, diverging from the Tanana River, enters the Slough, which leads to Fairbanks. It is midnight, but no one heeds the lateness of the hour. One of our voyagers told me that they were obliged to impose the curfew, whereby children were called to be put in bed by 10 o'clock in summer, otherwise their rest would be seriously interfered with. This struck me as an excellent idea; I had not heard of the curfew in other towns. On the contrary, a Fairbanks lady remarked: "In winter, we pay calls from 3 to 5 , in the moonlight; and the skies are also illuminated by the flaming Northern Lights." Alaska is indeed a land of revelations.

The first view of a town is interesting, and returning residents were keenly on the watch for their waiting friends on the dock. Some were returning after an absence, "Outside," of a couple of years. Others had simply passed the winter away, and in most cases were glad to be home again. As we proceeded towards the wharf the landscape disclosed green rolling hills, merging into mountains on one side, and the snowy summits of the Alaskan Range were dimly outlined; while, in a different direction, Mount McKinley, arrayed in clouds of ethereal rose, showed a gleam of its snow bonnet. The Slough is narrow, and the Yukon fills most of it. Now appears a row of cabins along the water front, some covered with flowers, others neglected; then frame houses, mostly one story, line the way. On the opposite side is Garden Island. The boat draws up to its anchorage, and the corrugated iron roof of the Northern Commercial Co. blocks the way. Diagonally across stands a white two-storied building with bow-windows, the Pioneer Hotel. Farther down, 
one remarks the Shaw House, Golder's Grocery, the lofty Masonic Temple, and the picturesque Public Library. On the other side are Pinska's Store, the Red Cross Drug Pharmacy, and the Model Café, painted brown. This is the only building which has been re-erected on the site of the unfortunate, devastating fire of years ago. Farther on are the Fairview Hotel and the Nordale, the latter and the Pioneer the two best hostels in town, but neither of them a Ritz-Carlton. Across the Slough, or, properly speaking, the Chena River, is a fine bridge, which unites the town with Garden Island. At the end of the bridge stands the pale grey Church of the Immaculate Conception, very prettily built, and surmounted by a green belfry, from which a gilded cross is suspended. Adjoining is the three-storied Hospital of St. Joseph. All the people speak most gratefully of the splendid work the Sister-nuns achieve in relieving suffering. Many a worn-out miner or half-frozen prospector has reason to bless these good women for renewed life. One cannot fail to notice near by the offices of the Alaska Citizen, owned by Mr. J. H. Caskey. They tell me it is the foremost newspaper in Central Alaska. On this side of the Slough is the terminus of the Tanana Valley Railway, which was built in 1905 . This road serves most of the rich mining creeks, and extends a distance of more than 50 miles. Now we come to machine-shops, and the hardware stores of the D. C. Co. ; a few small river boats are tied up to the bank.

Such is the first impression and general view of Fairbanks, which derives its name from a former Vice-President of the U.S.A. All the townsfolk had assembled for the great event, the arrival of the first boat from " Outside." People laughed, cried, and threw their arms about the new arrivals. Scenes such as this make one feel very lonely when travelling by oneself; but the Williams family are near me, and we are going to the same hotel. I have, moreover, quantities of letters of introduction, so that my solitary condition will not last long. I made my way to the Nordale Hotel. Luxurious travellers may be somewhat taken aback by the Alaskan hotels, but when you stop to consider how hurriedly they were 
constructed in the rush of a gold stampede, and built upon frozen glacial soil, which causes much warp, you wonder they are as good as they are. Fairbanks at present looks as if in a state of removal, especially along the front, where the remains of the big fire, in which an entire block was wiped out, form an eyesore. It is a pity that the municipal authorities do not clear it up. From my windows at the Nordale Hotel I look over a great congested mass of rusty, warped corrugated iron. Alongside is a shop, where the ceiling of another floor has fallen, and remains in a topsy-turvy position, reminding me of some of the buildings in London after an airraid. It imparts a look of unmerited hopelessness to the entire town. A sign which I note from the window reads as follows :

\section{Fire Sale.-Removel [sic].-Sale write [sic] here.}

My bedroom, or suite, was the grandest of the Nordale. The first small room was a bedroom, through which one passed to another tiny room, which they described as a sittingroom. I had a creaky bed, which must have supported many a heavy weight; the electric light was tied up to the bedstead by a man's well-worn necktie; a red Brussels carpet, very aged, had green cabbage roses sprawling all over it. The partitions, through which you could hear the slightest movement, were fashioned of thin boards, covered with canvas, and papered over. There was an electric bell, but you might ring this all day without result. The proprietor's son told me that " they didn't want to be bothered, so they had cut all the wires" - truthful, at any rate.

For this apartment I paid 3 dollars a day. I had to take my meals at a restaurant, of which there were several in the town, but the best undoubtedly was the Model Restaurant, diagonally across from the hotel. Here one found the usual Alaskan fashion, a bar counter with a line of stools in front, from which the men took their meals, instead of at tables. On the far side was a row of tables, and at the back a few curtained cubicles, where people could sit if they wished for privacy. The American waiter wore clean white clothes; 
and the food was excellent and well cooked, such succulent fare as caribou stew, moose steaks, king salmon, and the best frosted lemon pies I have ever eaten. It is a rule in Alaska that a very substantial meal can be served for 1 dollar a head, and you may have as much as is reasonable, which cannot be said to be dear, considering the shortness of the season and the expense and difficulties in obtaining food.

At the Nordale and Pioneer Hotels, their respective bars, which, in the rich days of the gold discovery, used to be literally afloat with champagne and whisky, have been turned into soda-water fountains, as has been the case throughout the country since Alaska became " dry." Since hard times have descended upon Fairbanks-that is, no startling discoveries in the way of gold have been made of late on the creeks-this hotel has remained much as it was since it was hastily thrown together, without any money having been spent in repairs or in bringing it up to date. But when you realize the enormous distances and the cost of bringing materials into the country, you forgive the dilapidated, inartistic surroundings and make the best of things. When Fairbanks was laid out in 1905-6, they had plenty of space on flat ground. Naturally they began the wooden pavements on the front; this they called First Avenue. They continued the town backward until Twelfth Avenue had been reached. Then Cushman Street became the principal thoroughfare for shops.

Fairbanks covers an enormous area. In 1901 this large town was simply a trading station, consisting of some Indians, a few log-cabins, and a general store or two.

Prospectors occasionally wandered through on their way to the rich goldfields farther north. At that time no one expected to find any great wealth in the Tanana Valley, which surrounds Fairbanks. It seemed fated, however, that Felix Pedro should be the discoverer of the hidden gold. When he mushed through the country, ragged and half starved, in 1901, on his way to Circle, which at that time beckoned all prospectors, he washed out a little gold from the black muck mud of a creek. But he had no time to bother with the small quantity he had found. His supplies were nearly exhausted; 
only sufficient "grub" remained to last him over to Circle. Consequently he mushed on. Circle did not favour him, and he continued mushing over the land searching for treasure. In 1902 he wandered back to the creeks, and eventually struck a rich pay-streak. No one seems able to say if this was on the original creek or not; but, at any rate, Felix Pedro struck his camp and found a fortune. News travels quickly, and his success spread like the fire-weed emblazoned all over the fields of Alaska. Thousands invaded the creeks, rushing in from Valdez, Cordova, down the Yukon, up the Yukon, over the inland trail, and still they arrived, gold mad. Claims were staked out, tents put up, the creeks and nigger heads were trampled over, the black muck was the centre of interest and speculation, its golden treasures were wrung from it and the refuse piled into ugly mounds. Thus Fairbanks was estab. lished, and became incorporated in 1903 with a Mayor and City Council. All the paraphernalia of the mushroom mining town was here. The place, just emerged from primeval spruce forests, reeked with bars.

Champagne at 20 dollars and 30 dollars the bottle took the place of the native hootch. Money flowed like water; dance halls, faro banks, pokers, roulette, all were there, hand in hand with every temptation of the devil, everything to beguile the gold.

Those who worked not with the hands used their brains to fatten upon the credulous. The painted dance-hall jade and harpy sold their languishing smiles, drugged the drink, and grabbed the poke.

In the music-halls, hatfuls of nuggets and gold-dust were passed to the favourites instead of bouquets. The painted lady bargained and smirked, and chose the man with the biggest nuggets. Dwellers in the Fairbanks of the day were gamblers all, their motto, "Chickens to-day, feathers to morrow." How few of all these gold-seekers retain their fortunes! In most cases it was " easy come, easy go " ; and many men, after squandering millions, passed to their eternal slumber in a pauper's grave.

In 1905, during the stampede, the gold outpour was 
$6,000,000$ dollars. Thus it assumed its place as one of the world's greatest gold-producers. Just at present there is a depression in and around Fairbanks, which everyone is confident is merely temporary, a result of the high cost of living and extravagant freight charges. The shopkeepers must buy merchandise for a year ahead, this requiring much forethought and capital. They are, therefore, obliged to charge excessive prices, to recoup their outlay, to obtain interest, make some profit, and pay their employees. All the requirements of Fairbanks must be brought in by the river route during the short summer season, as in the winter it is not possible. The cost of the smallest of packages if sent over the trail by the dog-team mail is prohibitive. In the drug stores they have stocks which are surprisingly complete-almost everything in the toilet line which you can purchase in the States. The prices, however, in many cases are double and treble the usual cost, but, as the proprietor explained, " With freight 40 cents a pound, the storekeeper has to lock up his capital for a year or more, and he must make a percentage of his outlay ; besides, wages and food are also very high."

The rich cream of the gold-fields has long been skimmed, but there must remain millions hidden in Mother Earth, the placer mines, thousands of acres of auriferous gravels, and scores of known ore-bearing ledges of a grade too low to be worked under present conditions. But the projected Seward, Nenana, and Fairbanks Railway will open up this vast rich country, and again flood the land with wealth. With the opening of the railway, Fairbanks will eventually become the Metropolis of Alaska, as all the mining camps scattered upon the creeks for miles around draw upon it for their equipments and necessities, because of its central position and distributing power to the interior of the country. It is a fact that in 1915 the Alaskans bought from the United States 28,000,000 dollars' worth of goods, and exported 16,000,000 dollars in gold, silver, and copper. Thus the present slump in the gold industry around Fairbanks is due to economic conditions, and not to the exhaustion of its mineral deposits. A great portion of the Tanana Valley has not even yet been explored, and 
every year brings prospectors who continue to " mush" "over the country, ever in the hope of locating an El Dorado. If the Government, or private capital, could erect a gigantic electric power plant near Nenana, in close proximity to the huge virgin coal-mines-these mines are in the Tanana Valley, some 40 to 60 miles from Nenana-the cheaper electric power and the aid of the coal-mines could then work masses of low-grade ore at enormous profit. Consequently the people are optimistic. They are jealously holding on to property and claims, awaiting the advent of the railway, which will lessen their present disadvantages and change the entire condition of the country. What Johannesburg is to Africa, so should Fairbanks become to Alaska. No doubt, with the opening of the railway in 1921 a tremendous impetus will be given to the lode-mining industry, and the district will become as valuable for its hard rock as for its placer mines. In 1916, 7,000,000 dollars were extracted from these hundreds of miles of placer gold-fields. On a visit to Fox City and Engineer Creek it was interesting to see water trickling over gold nuggets and dust, and to inspect the sluice-boxes and riffles. I should like to have been present during the recent clean up, to watch the process of scraping the gold from the riffles. However, I was allowed to pan some gold in the creek near by.

People become expert manipulators of the pan, but, believe me, it is a back-breaking job! You reach over to the bottom, scoop up a pan half filled with gravel, and by a dexterous method of shaking and swashing, the water and gravel slope off, and the heavier matter, the gold, remains at the bottom of the pan. It must prove most exciting when you discover the big nuggets. The process requires time, patience, and labour. Never shall I forget my first panning for gold. In future, when in our great cities I purchase anything made of the yellow metal, my thoughts will wander to the creeks of Fairbanks and to my first gold-washing experience.

Some of the richest creeks in this district are: Cleary, which in 1906 produced 5,383,000 dollars; Ester, 1,200,000 dollars; Fairbanks, 1,500,000 dollars; and Dome (in 1908), 


\section{2}

FAIRBANKS, THE HEART OF ALASKA

1,700,000 dollars. Other rich creeks are Goldstream, Pedro, and Little El Dorado. Deposits of antimony in considerable quantities have been shipped to the U.S.A., and tungsten ledges are also worked. It is estimated that the total production of gold from gravels in 1916 was 7,000,000 dollars. Besides the great gold wealth of the Fairbanks environs, huge mining possibilities lie in the Iditarod district, to the southwest; Koyukuk, some 200 miles north; Brooks, in the Tolovana, 100 miles north ; and Ruby district, 250 miles west. New pay-streaks are often discovered, and a "musher", to-day becomes a millionaire to-morrow. It is reported that in one year 1,000,000 dollars' worth of gold has been produced from the Tolovana district. Labour is scarce and expensive; an ordinary miner earns 7.50 dollars (about $£ 1$ 10s.) a day, including his board and lodging. A miner will eat only of the best, and demands a big quantity of food, otherwise he quits the job. Three substantial meals are expected, including meat, puddings, pies, cakes, plenty of jam and other good things-and food is very dear. A chicken will cost from 4 to 5 dollars; eggs, 2 dollars a dozen; tomatoes, 1 dollar a pound; cucumbers, 75 cents each; salmon, 25 cents a pound-on the boats, 10 cents a pound-and so forth. Labour is paid at the rate of 1 dollar an hour, so that a car. penter, painter, or other workman can make 10 to 15 dollars a day, working as many hours as he chooses during the summer season, when there is continuous daylight. Here, as at Dawson, every item is 25 cents (1s.), from a newspaper to a packet of pins. They may give you two packets of the latter for the coin.

The shop-windows interested me; it was unique to come in contact with such wares as miners' camp outfits, mosquito veils, and mosquito gloves made of a sort of twill, which the wily pest fails to penetrate. They tell one that this year they are singularly free from insects, but that some years they are so thick, one can catch them in handfuls-these seasons must indeed be a torture. In the jewellery shops are samples of local ingenuity in the shape of rather handsome long gold chains, composed of nuggets fastened together; Masonic 
jewellery encrusted with nuggets; large and small lockets of glass filled with gold-dust; and bracelets of nuggets, rings, brooches, and souvenirs generally. An amusing shop is kept by Mr. J. O. Ellis, an old-timer, who calls himself a pirate, advertises as such, and also owns "The Pirate Shoeing Shop." I purchased some trifles from the Pirate, who, with his smiling face and keen, kind black eyes, I should say rather misdescribes himself. There are several curio-shops selling furs, bear rugs, dolls made of skins by the Indians, birch-bark canoes, and a miscellaneous collection of oddments. One cannot fail to notice the immense plate-glass windows in some of the shops; it quite amazes one to think of what they must have cost, bearing in mind the enormous difficulty of getting them here. Many of the shops have put the shutters up until the coming of better times.

Mr. Pendleton is quite a local character; he is responsible for the best and freshest candy-made at Fairbanks, and to purchase his excellent chocolates requires a ritual of its own. Mrs. Davis and I were offered, and accepted, two big chairs, whence we observed the candy-maker slowly and carefully packing our boxes of his delicious wares. They might have been objects of art so deliberately were they chosen. At intervals he would come outside the counter and present a particularly nice bonbon to each of us, chatting all the timeand he is some story-teller! Finally, he tied up the boxes with what he described as "shimmy" ribbon, adjusted a bow, and, bowing gallantly, presented the sweets. It was as amusing as a play.

At Gordon's, the emporium for women's clothes, we found beautiful furs, model dresses-in fact, a very good selection of fashionable goods. In the old days, when money was plentiful, the proprietor imported gowns straight from Paris. The ladies of Fairbanks, it should be added, are moted for stylishness and the elegance of their dress. The town is well equipped with public buildings, and the principal religious denominations are well represented. St. Matthew's, the Episcopalian church, is a most picturesque log-cabin structure, facing the Slough; the Church of the Immaculate Conception 
(Roman Catholic) is situated on Garden Island, at the terminus of the bridge. There are also the Presbyterian, St. James's, Methodist, and a branch of the Christian Science Church. As to fraternal organizations, there are the Oddfellows, the Loyal Order of Moose, the Arctic Council, the Fraternal Order of Eagles, the Knights Templars, the Shrine Club, and the Masonic. The latter temple is a fine building, prominently situated on the Slough. There is also the Woman's Civic Club.

At the Orpheum and Thorne's, both with a large auditorium, the picture plays are shown nightly. On a tract of some 60 acres, set apart by the Municipality for a public park, the dog-team races take place during the winter months, and in summer the automobile races, the base-ball matches, and all recreational exercises. The police department is efficient, the Municipal Court being administered by a town magistrate, who also fills the office of town-clerk.

Fairbanks enjoys a fine public-school system, which would reflect credit on any city. Its annual expenditure for educational purposes is some 18,000 dollars, and the big two-storied, well-built school building is entirely up to date, with electric light, steam-heating, spring-boards, toboggans, tilts, and everything to interest the child at playtime. The building cost 40,000 dollars. There are also physical and chemical laboratories, with everything necessary for instruction.' The full four years' course of the high school, when supplemented by recommendation, meets all entrance requirements of the Pacific Coast universities. As instancing the patriotism of these young people, on the occasion of three drives organized for the War Loan, they raised 123,000 dollars. Fifty-two former scholars served in France, and the Service Flag of the school shows four gold stars, telling that four precious lives had been sacrificed to the great Hun orgy of blood. A pretty way of perpetuating the memory of these fallen heroes is the planting of groups of trees in honour of each life. These trees are carefully tended and looked after by the different classes, who vie with each other in perfecting their growth and beauty. During the war the Boy Scouts promoted a ".Chicken Drive," 
collected the small sum of 10 cents from each person, and were able to place 568 chickens on the devastated farms of France. Practical charity!

The Bureau of Mines, the Alaska Station of the U.S.A., is under the capable management of Mr. John Allan Davis. An optimistic believer in the future of the country, Mr. Davis says: "With the arrival of the railway, the expected electric power plant, and the development of the coal-mines around Nenana, Fairbanks will again become the greatest city in Alaska."

The Bureau of Mines, in the geographical heart of Alaska, has been created to assist the prospector, and thus ultimately the development of the mines. It conducts identification tests of any specimens of Alaskan ore without cost, or will make a thorough quantitative assay for a nominal charge. But the ordinary prospector knows and is chiefly more concerned about gold. Yet there are dozens of ores to be found here that would pay him far better to exploit than the fascinating yellow metal. That he may not pass these through lack of acquaintance with their appearance and qualities, the station has provided an extensive collection of specimens, and a comfortable library containing mining and scientific textbooks, which the prospectors may use as a clubroom during the long winter months. Tungsten and molybdenum, antimony and bismuth may therefore prove to be a more valuable asset to Fairbanks, seeing that they are much needed in national economy.

Much of the coal in the interior about Nenana is a lignite comparable to that found in North Dakota, and containing a high degree of moisture. This makes its use in a raw state uneconomical. But the Alaska station of the Bureau of Mines is even now working to determine the best and cheapest methods of handling this fuel, which may prove to be the economic salvation of interior Alaska. A movement is on foot to generate power from a central power plant located near the lignites at Nenana.

A central power plant, utilizing the immense coal-fields, and transforming the energy by carbonizers and gas pro- 
ducers, would provide cheap motive power for hoists, dredges, mills, or mining camps in the interior. "Give us the railway and motive power, and we will pay the nation's War Debt," say the citizens of Fairbanks.

I visited some fifty private dwellings, the homes of the richest people, as well as those of the humblest. In one of the log-cabins lived an Indian woman who has the distinction of having divorced her white husband. She showed me over her home, and displayed some beautiful silver fox skins. She is an adept in cutting up, tanning, and remodelling furs. In another cabin an Eskimo woman, married to a white man, offered me lettuce from her well-kept garden. She has a granddaughter of whom she is very fond, and who is being trained in domestic duties. When I called, the lassie was receiving her first lesson in the best method of preserving salmon. A gorgeous white Polar bear-skin rug belonging to Mrs. Davies was in process of curing; it sounded strange to hear the Eskimo woman explain how she " dug the meat out of its claws." Fairbanks is distinctly a city of homes; it was astonishing to observe how nicely appointed and artistic some of the interiors proved to be. Mrs. John Allan Davis's house, for instance, was a model of its kind; you would not find a better bathroom in a palace. Almost everyone possessed gardens which were bowers of beauty. As atDawson, everyone takes a delight in making the home attractive. Fairbanks is not only optimistic about the future in regard to the goldfields, but also as to its rapidly improving agricultural prospects. Much local interest is taken in the work of the Government Experimental Farm, of which there is a companion one at Rampart, and another at Sitka. I motored out to see the farm, which is some 5 miles from town. Along each side of the road were fields of lovely wild-flowers similar to the spring flowers of the Swiss Alps. Whole hillsides were spread with the scarlet fire-weed, white orchids in abundance, and miles of blue lupins. Mr. and Mrs. Guy Erwin, my host and hostess, were anxious I should see how wonderfully and luxuriously nearly all kinds of vegetables grow in this rich virgin soil. The only drawback seems to be the shortness of 
the season. I had the pleasure of meeting Mr. and Mrs. Snodgrass-the farm is under the direction of Mr. Snodgrass -and was shown wheat, barley, and oats that had matured well. They are experimenting with various Russian (Siberian) grains, blending and perfecting them in order to ascertain which are best adapted to Alaskan soil. Last year 100 acres were cultivated, 90 of grain, and 10 of potatoes. Most of the grain matured; and at Rampart they had the same result, owing to the fact that the killing frosts arrived two weeks later than is normal in this region. A period of 123 days elapsed between the last frost in the spring and the first killing frost in the autumn, and the Siberian wheat matured perfectly. Neither corn nor apples can be grown with advantage. Alaska is encouraging farmers to take up the land about here, for there are thousands of acres awaiting tillage, land on which homesteads could easily and quickly be built. The land is free; you file on, make your farm, but must reside there at least five months in the year and do some development. It is a good offer, remembering that your market is at your door, so to speak. Fairbanks and the creek towns will take all you can raise, and more, paying a very tempting price for it. Fairbanks advertises its need of 500 farmers, together with their wives and families and all their relatives-settlers are wanted for the miles and miles of land without a living soul on it.

Mr. Wm. E. Waugh, a pioneer, told me that in 1918 he raised 2,700 dollars' worth of potatoes, and expects to exceed that amount this year. In some cases the potatoes that I have eaten are inclined to be wet and soggy, not having that mealy, floury appearance which we appreciate in England. This is due to the fact that as the season was so short the tubers had to be dug before properly matured. I also went over Mr. Rickert's noted farm. He has 80 acres under cultivation, and it was good to see the perfect tomatoes and cucumbers he was growing under glass and in the open. The lettuce and celery - the latter Alaska claims to have the best flavour in the world-were progressing in fine condition, as well as were monstrous cabbages and turnips. At Marshall 
Erwin's pretty home, Mrs. Erwin, who is a clever writer and reciter, presented me with a lovely basket of tomatoes, cucumbers-grown in her hot-house-berries, and fruit. She was describing to me the glories of the Aurora Borealis. "It is," she said, " one of the natural phenomena which make the North famous. Great arches of light shoot across the heavens, assuming myriads of colours. People are awed and amazed at their sheer beauty, for these Northern Lights wave back and forth in enchanting, ever-changing forms and colours." Mrs. Erwin was so inspired by these wonders that she penned the following poem :

\section{THE AURORA BOREALIS.}

Fling to the sky your rainbow banners

Of filmy gauze the angels weave;

Trailing streamers of yellow sunbeams, With tints of coral and autumn leaves;

Rolling, waving, leaping high,

They ripple and play in the Northland sky.

Bands of fire and ribbons of rose,

In an ether sea of midnight blue;

Opalescent billows of pearl,

Golden dream-stars peeping through,

Lovely as down of angels' wings,

Wonderful pictures the North sky flings.

For tourists of the future-and assuredly their numbers will be legion-when the Seward railroad is opened, no summer cruise could be more delightful than that from Skagway to Fairbanks, and out over the railroad to Anchorage and Seward. At present, one takes a motor stage from Fairbanks to Chitina or Valdez, and then the Copper River railway to Cordova. Going down the trail, everyone affirms that the scenery, with its lofty snow mountains, is indescribably magnificent. I very much regret that time does not permit me to visit this interesting tract of the great country. To see this vast Alaska, one requires more time than the short summer season affords. Boats are very irregular, and my path leads to Nome, that Mecca of my childhood's dreams. The Williams family take this trail; they have secured two 
Ford cars at an enormous cost, and this morning I regretfully watched them off, as did half Fairbanks. They were well equipped for the journey - the two boys, Menen and Henry, agog with excitement-with mosquito veils, cameras, dustcoats, and all the items for a comfortable trip. The last I saw of them was the white mosquito-gloved hands of young Menin waving to me from the increasing distance. On the last night of my ten days' stay a reception was given as a farewell mark of esteem to the Rev. and Mrs. H. H. Lumkin, who, for five years, had been the beloved pastor of St. Matthew's Episcopalian Church. Bishop Rowe was present, and everyone of note in Fairbanks attended. The function was held in the commodious Masonic Temple facing the river. The hall was handsomely decorated, and a programme of music and recitations was rendered; one especially appropriate poem was written for Mr. Lumkin by Mrs. Erwin, and recited by her. A presentation of ermine furs was made to Mrs. Lumkin, and other tokens of appreciation to the pastor. One thing struck me as novel, and most pleasing. The Catholic priest and the Presbyterian minister also came to pay homage and to honour their fellow-shepherd. In many towns there is a certain amount of jealousy existing. It was, therefore, a pleasant feature of Fairbanks life, loyally friendly to religion, without regard to denomination, brotherhood ruling in the true meaning of the word.

I was introduced to everyone; they were interested to meet a real English cheechako, and I was delighted to meet the representative ladies of Fairbanks. I had heard that they were the best-dressed women in Alaska, and certainly many of them looked as if they had just stepped off a Parisian boulevard. While the reception was at its height, the steamer which was to convey me down-river hurled forth its mighty blast, summoning her passengers. It was midnight when I arrived, and midnight when I left. Many friends crossed over to the boat to bid us adieu, as many of the townspeople were leaving for the "Outside." As the boat puffed down the Slough, all the reception people stood on the balcony of the Masonic Temple waving to us. 


\section{FAIRBANKS, THE HEART OF ALASKA}

Hospitality and friendliness is the keynote of Fairbanks, as in all these Northern latitudes, and as the distance lengthens between us, I, for one, sincerely hope that the present mining difficulties will soon be a thing of the past, and that the reputation of Fairbanks as " the golden heart of Alaska" may yet be abundantly justified. 


\section{CHAPTER XV}

\section{TANANA}

AFTER floating over the Tanana River for more than 500 miles, from Tanana to Fairbanks and back again, I once more find myself at Tanana. Coming down-stream is a quick passage. We make no stops to speak of, and even after pushing forward two ugly barges, arrive in forty-eight hours, back once more to the Yukon River, which flows past my window in grey, sluggish volume, ever hurrying onward to the Bering Sea. To-day, let me confess, is the first time I have ever regarded the mighty Yukon as ugly. Dark, threatening clouds drifting down from the Arctic at short intervals contrast with endless volumes of water. The black earth is soggy, and the rotting wooden sidewalks are like sponges, so full are they of dampness. Upon landing from the s.s. Alaska, which was most comfortable, I am set down at Tanana, which everyone acknowledges to be a "God-forsaken place," to await the tardy arrival of s.s. Seattle No. 3, now held up at a place called Holy Cross, on the lower reaches of the Yukon.

As the Alaska pulls out, bound for Dawson, I wave a fond farewell to my genial friends, feeling like Caliban, left alone, as in " The Tempest," on the shores. And an Arctic gloom settles upon my soul. What am I to do here for an indefinite period? Simply to gaze on the river, the flat green banks opposite, and walk in the one long street or road? Attempt to explore the back of the town, and encounter weedy pools, which people tell you to avoid, or tempt the animosity of millions of mosquitoes? I wander down the street, and enter the general store, for everyone is glad to talk to a cheechako in this isolated place. I open by buying postcards. "You should be here in the winter," says the storekeeper, as he shows me some of his wares, among them a buckskin shirt 
fringed with leather and ornamented with the bead-work made by the Indians. "Why?" I demanded. I pictured, in my mind, the cold ice-bound land, with the blizzards sweeping down from the Arctic. This wet summer day was unpleasant enough. "We have fine times in the winter. See these dog pictures?" He opened a package of photographs, displaying his wife's dog-team, eight fine malamutes harnessed to a sledge. She was smiling, amidst a quantity of fur rugs, out of her parka and wolverine-bound hood. The parka is a one-piece garment made to slip on over the head, with no openings to let in the cold. It is usually made of fur, sometimes of canvas. The hood covers the head and, if pulled down, a greater part of the face. The hood is bound with wolverine, the only fur upon which the breath does not freeze, and therefore highly valued by people who live-in this Northern clime. Everyone appears very fond and proud of their dogs and team. It must be thrilling to race along on the immaculate surface of the Arctic snows. Another photograph shown to me depicted the arrival of the Koyukuk mail team from the Arctic Circle. This team was composed of a single leader, a big handsome dog, and fourteen others in pairs. Looking out upon the river, now so vibrant with activity, it seems strange to picture it blocked by King Frost. The freezing process arrives with only a few days' warning. It begins to be choppy with small ice, and in three days, or less, it is a solid ice-floor.

Another picture represented Tanana at 40 degrees below zero. All was white, and each chimney resembled a smoking factory stack. Tall spiral columns arose, ascending into the sky, this peculiar effect being caused by the warm air meeting the frozen atmosphere. It is not uncommon to have 60 and 78 degrees below zero registered. When it drops to this temperature, people endeavour to avoid going out; but if a journey is imperative, they have to proceed very slowly, as any violent exercise may stop the action of the heart. A breath of this frozen air on the lungs feels as if one had inhaled burning steel. A horse, under such conditions, will often get his lungs chilled and die, whilst sometimes on the 


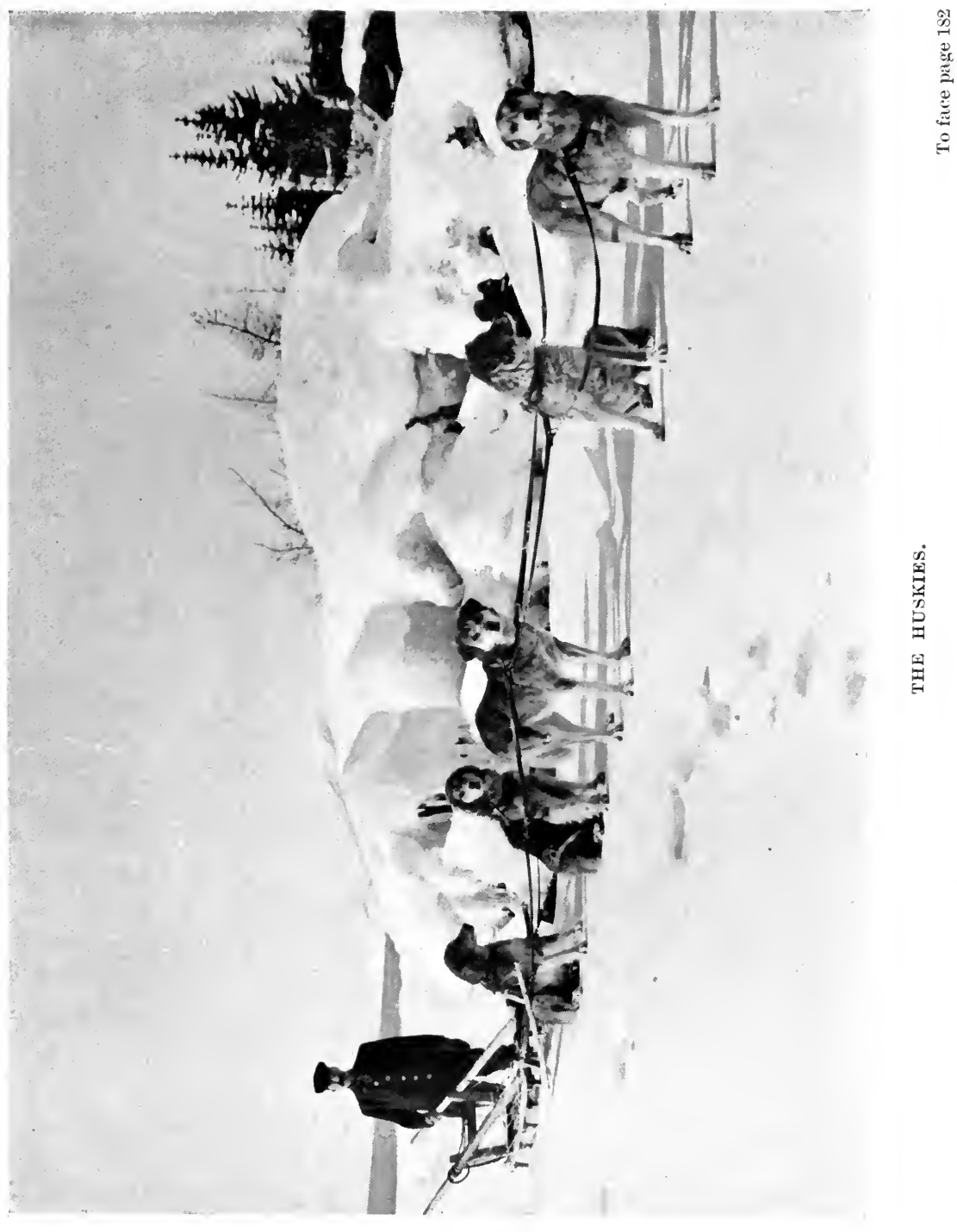



trail a dog's flanks will become frozen; you freeze without being conscious of it. More photographs depict the breaking up of the river ice about June, when the ice becomes massed in blocks as big as houses. The current piles these up as high as the telegraph-poles, in fantastic fashion. A scant three months of summer is all that is vouchsafed these Northern lands. For the other nine months the landscape is wrapped in white; all is still, except when Boreas leaps down from the Arctic and howls through the country with his accompaniment of blizzards. Yet the people actually love the winter; they know how to prepare for it; their cabins are made snug and air-tight with cement, generous cords of wood are stored, whilst in their caches food and game are preserved; the stoves are lighted, and never permitted to go cold. Just as there is no darkness in summer, so in the coldest season, with short days, they will see by natural light for a few hours only. Yet they are content, with their church affairs, cardparties, and dances. I have never met people more loyal to their country than these Yukonites and Alaskans. When I first visited them my astonishment was great, as I was shown over these tiny frame houses and log-cabins, where resided the rulers of Alaska and their families-judges, bankers, traders : in fact, all classes. However, upon entering their homes, I, who have always lived in the biggest cities of the world, thoroughly understood. A cosy cabin, plenty of good reading matter, and a first-class dog-team-surely a winter in the Arctic would prove most enjoyable. Everyone knows and helps the other; it is certainly an Arctic Brotherhood. One can visualize the white trails, especially those farther north, in the Koyukuk, Kobuk, and to the south the Iditarod countries, and form an idea of the life of those men who stay there, shut in from the world, their only friends their dogs, their only distraction the coming of the mail.

A sourdough related how he was cooking his breakfast bacon one morning, his dog anxiously looking on. The cabin door was ajar, and just outside was the litter of pups. The man went into his cache after some flour, and when he looked to the fire to see how the bacon was progressing, lo and 
behold! the pan and the hot sizzling bacon had disappeared, likewise the dog. Upon investigating, he found the fryingpan sitting in the snow, and the malamute and her pups clustered around it, having their breakfast first! The cleverness of the dog in taking in its mouth the handle of the hot pan and placing it in the snow to cool! Another thing in which these dogs are adept-they can open any tin can quite easily. Their long front eye tooth makes a good puncture, and their teeth are strong, sharp, and rip a cover off quickly. By their sense of smell they will at once know which tin contains meat. This only will they attack, leaving the tins of vegetables or jam untouched. As a rule, a dog will not steal from his own master, but has no compunction regarding other men's food.

Along the trails where the mail is carried periodically during the winter cabins or huts are stationed, with perhaps a wood-chopper or Indian in charge. The dog-mail team arrives, the dogs worn out with the cold and the harshness of the elements. A meal is cooked, man and dogs are fed, the latter usually with dried salmon and rice. Then the driver and his trusty dogs lie down and sleep together for warmth, until ready to start off on the frozen track. Dog and man are chums indeed. Very clever are the dogs in discovering a fallen man buried in the snow. They will sniff, howl, and paw the snow, refusing to proceed until they have rescued the man. The malamutes are very like the wolf : they howl, but do not bark ; their faces are almost human, their intelligence very acute. They are a mixture of spitz and wolf, their coats mostly of wolf-grey marked with a darker colour and stripes of black. Many are the stories told over the crackling wood fires of dog life in the North. My host of the Grand Hotel, Scotty Kay by name, is a sourdough who has passed over twenty years in this country, and who " swears by it." He showed me his new dog-house. It was neatly built, with comfortable bunks. A couple of huskies, reposing on the roof, eyed me curiously. We stood on a primitive wooden platform, and Scotty Kay, whom everyone knows and styles a good fellow, was explaining things in general. After 
telling me with pride that his big wood pile was worth 1,700 dollars, he pointed out over the Tanana Valley, which we could see for miles stretching away to the western horizon, and said: "No one knows how much mineral wealth is concealed over there; that land has scarcely been walked over yet. All that vast region is practically virgin soil, as far as the timber-line where the wood-choppers hold out." My eyes followed his direction, rising hill and green valley for miles around, and I wondered if any, and how many, Bonanzas lay unrevealed by Nature, and whom she will "glut with her wealth," as Robert Service has it. That genius seems to have found, and used, every accurately descriptive phrase in revealing the beauties and legends of this fascinating, ever-mysterious land. My landlord's cognomen " Scotty" Kay reminds me of other curious nicknames which abound ; amongst them are Hungry Ike, the Nenana Mare, Dirty-faced Dick, Water-front Brown, Eat-'em-up Jack, Swift-water Bill, and the Malamute Kid-all celebrities of these parts. The Malamute Kid has the reputation of having the finest dog-team and of being the best driver. In an interval when the rain ceased to pour, I visited Fort Gibbon, the farthest-north training-station of Uncle Sam ; the fort blocks the northern end of the town of Tanana. The various buildings, large and up-to-date, are painted a deep chrome, with red roofs, which invests the place with a cheerful air. The first structure comprises a store wherein the boys can buy cigars, tobacco, candy, and other trifles. I noticed barrels of soda-water packed in shavings, as everything has to be protected from freezing. Here is a large hall which has many uses-the Picture Palace. Lectures are given, plays produced, in winter the soldiers train here, tennis is practised, dances arranged, and when this useful place is not monopolized otherwise it remains a gymnasium for the rising generation. It should be named "Philanthropist Hall"! Only last evening I saw a very good cinema film there, Geraldine Farrar in "Temptation." The audience was composed mainly of soldiers, some 250 of whom are stationed at the fort. The night previously a young bride-elect had 
arrived by steamer to marry one of the younger officers. They had just gone through the ceremony, and this was their first public appearance. Several humorous allusions to the wedding were thrown upon the screen, which must have been embarrassing to the newly wedded pair, who occupied seats in the front row. Another feature, hardly, I imagine, confined to Alaska, is that the boys make comments as the scenes are shown, either of pleasure or of displeasure. It is a great blessing to the people to be able to see what the world is doing, although in the past tense, as it were. My officer friend who showed me over Fort Gibbon told me that in 1917 175 men went out to the Great War, and in 1918,225, so that from this far country, 10,000 miles away, brave men covered the long trail to fight the Hun. The barracks, hospital, mess-rooms, quartermaster's and guard rooms, were kept in perfect condition. The Commissary has no enviable task, as he must arrange for a year's stores in advance. I noticed a mighty wood pile, and was informed that it comprised 6,000 cords. Near the wood pile were the barrack mascots, with which, as a visitor, I must be made acquainted. These were two darling little brown bears of two months old, which a soldier had found in a cave, the mother having been shot. The youngsters, Fanny and Babe, entertained us immensely, turning somersaults whenever told, and dancing on their small hind legs. My visit to Fort Gibbon proved most interesting.

It is the end of July, and cold as the Arctic, the cold that people often allude to without comprehending its real meaning. Wind and rain romp together, holding high carnival along this broad surging river.

As I sit by my solitary window looking out upon the cheerless Yukon, huddled up in every warmth-giving garment I possess, with even a hat on to keep my head from that icy feeling, I am indeed depressed. Will it ever stop raining? And when will that laggard Seattle No. 3 arrive? So I ponder. The only woman in the hotel beside myself is the wife of the Alaska Inspector of the Knights of Columbus. We sit for a while shivering in the public room, then retire to 
our own respective apartments. We meet again to commiserate, and wonder how long it will be before influenza and pneumonia attack us. There is only cold water to drink, and horrible food to eat. Next door is the Chinaman's restaurant, and I have to patronize this celestial caravanserai or eat nothing. No, the restaurant is crude, to say the least, and the food anything but tempting. But with the cold and the rain, one must eat sometimes. I can truly say I have known the gnawings of hunger at Tanana. The proprietor of this small café is a Chinaman married to an Eskimo woman, and a rather pretty girl who waits on table is their daughter, a flower-bloom of Chinaman and Eskimo, named Rose. She is fourteen; a long silky braid of hair hangs down her back, her dark eyes are almond-shaped, and her skin the colour of pale butter. One often runs into rather mixed families about this latitude. It is a favourite resort of the squaw-man, and just above this town is Whisky Lane, where many white derelicts live sub rosa. My meal consisted of miserable coffee and a horrid mess of ham and cabbage, watery and fatcharges 1 dollar. After this non-warming, non-satisfying repast, I retire to that little room to shiver, and watch the waters roll by, and descend. Shivers strengthen their hold and turn into severe chills. The lady of the Knights of Columbus and myself waylay Scotty Kay, with the gratifying result that the furnace has been lit, and a gurgle proclaims itself in the steam-pipes. A glow and real heat relieves our misery. What joy! Never mind the unappetizing food, if we can only keep warm. Now we look out in defiance upon the cold, turgid Yukon as we listen to the drenching, continuous rain, content to be under cover.

My sympathy is more than ever with those mushers searching for gold on the trails. What a wearisome life! Yet they are content.

The U.S. Marshal Vawter has the best house at Tanana, a double-storied log-house, unique in style, with a green roof. I looked at it in envy when I passed in the drenching rain. It appeared invitingly homelike, with dainty curtains, and flowers in pots on the window-ledges. The Marshal's 
next-door neighbour is the small gaol, and fortunately nearly always unoccupied, for there is little crime in these parts. An Indian may get troublesome as a result of partaking too freely of hootch (native brew), but even that is not frequent.

Archdeacon Stuck is also here, awaiting the return of Bishop Rowe from Fairbanks. I had a short conversation with him in the general store; he promised to call. Another night has passed, which has merged in a cold morning with the rain still descending in torrents. There is no nice maid coming in with refreshing tea and hot water. I pull up the blind, gazing out hopelessly on the Yukon, still rushing by in angry mood. During the night the deluge was so great it awoke me, and I lay wondering if the river would submerge its banks, undermine the mud-bank, and carry us, willy-nilly, down-stream. The water is rising almost to the level now. Fortunately, this has not yet taken place ; and on our side there is plenty of high land where one could retreat in such an emergency, although a water-sogged log-cabin or tent would not be exactly comfortable. Again I long for sunshine and the arrival of s.8. Seattle No. 3. There is no bell to ring, and if one did, nothing would happen. If I want hot water I must run downstairs to the Chinaman's kitchen door, with a jug in my hand, and most likely meet several men on the way. It is cold and damp. I am not cheerful as I prepare to robe myself, and know that if $I$ eat at all it will have to be that detestable food of the Chinaman's. I go without until about lunch-time. Then hunger drives me once more to the café. No wonder the men do not bother to wash or shave too frequently. It's a different thing when you step into a luxurious modern bath and turn on a tap of pleasant warm water; but when you are in a continual state of shivers, and the rain dashes buckets of water ceaselessly on the windowpanes, you enwrap your clothes abont you and look askance at the crude and cold arrangements for your ablutions. I fully understand now what old-timers call " a lick and a promise."

However, it is interesting to have passed through all condi- 
tions of life, and a sense of humour is a thoroughly good companion. In regarding the present, my mind goes back by way of contrast to those millionaire homes I have had the good-fortune to visit all over the States; visions recur to me of the ideal surroundings, the marble, onyx, and other baths with silver fitments, the acme of modern science and comfort, and made more beautiful by the good taste of my various hostesses; the subdued lights through alabaster ; the fineness of embroidered and monogrammed towels, fit to dry an angel's wing; the fragrance of soaps, powders, water softeners, perfumed crystals, and every known luxury under the sun. It is a pardonable reverie to recall these things, so poignantly missed at present; and how much baths will be appreciated by me in the future! This hostel is filled with men who also await the arrival of the steamer. Patience is indeed a virtue. Sadly I wander downstairs; there is the usual lot of men sitting round, and I pass through, dreading to enter the Chinaman's restaurant. But I must at least have one hot meal a day; at night I prefer to take some biscuits (called crackers here). My evening meal consists of biscuits, a tin of devilled ham, an orange, small and dear, finishing with a few chocolates in the seclusion of my room. I greatly prefer this simple repast to that offered by the best restaurant in Tanana. However, I must eat something hot, and I " hike" to the Chinaman's. A former bar counter runs along one side, and on the other are two tables. Only one old sourdough and a couple of half-breed Indians are eating at the counter. I seat myself at a table, and Rose smilingly appears. She names the items in their limited menu. Most of their ingredients originate in the cans which are packed on shelves over the bar. The very look of the people eating disgusted and put me off all thought of food. I wonder what Lucullus would have done here. I choose ham and eggs-that seems the least offensive. It is perfectly immaterial to me, but a cold, empty interior appeals for something warm and sustaining. Indians, half-breeds and half Eskimos-I am not yet in the country of the real Eskimo-pass by the window, where a vine is trained in a primitive fashion to crawl on some bits of 
string, making a sort of spider's web of green. Rose seems very proud of this greenery, and confides to me that her Eskimo mother had arranged it, also that when the term begins she will again go to school. She gets on well, except in grammar, which she does not understand. Her father thinks she needs no further education, but should stay at the restaurant and work for him. Poor Rose! Youth she has, and a mind awakening, yet her present life is bounded by the serving of untempting plates of food to these rough, unkempt men. Hers is a continual march from the bar to the dimlylit kitchen behind, reeking with steam and obnoxious smells. When Rose swings open the door, there gleam battalions of tin cans, like evil eyes watching from within. Glimpses of the Chinaman are revealed, his sleeves rolled up, manipulating pans and concocting eatables. Rose brings me my plate, and I dally with it. Contemplatingly, I reflect upon conditions and humanity. What does the Almighty think of all the peoples $\mathrm{He}$ has created, each in their own environment, as He looks down and reads their hearts, aims, and ambitions : the different castes that are bridged together, the matings, and mismatings, of creeds and colours? Then consider, side by side, the people of refinement, of education, knowledge of life in its most desirable of aspects. The contrast between these strangely commingled breeds, their squalid circumstances, their narrow outlook, primitive and ignorant from no fault of their own, is striking indeed. They did not choose their parents, or their conditions, when that Divine breath of life pushed them into existence. Had my people been as theirs, I should have been exactly as they. Why, then, should I scorn them? God also implanted His Divine atom in these people who appear so strange and repugnant to my eyes. Because I had advantages, why should I regard myself as superior, and look down upon them? The great Modeller cannot create us all alike. I smile at Rose, bow to the others, as I pass out, endeavouring to assume an air of Christian camaraderie.

In the hotel, which bears the misnomer "Grand," they all endeavour to be kind. Here, also, you see them sitting 
at the bar, these sourdoughs, men who have tramped the country. Two or three will get together for a chat; they mount the stools as of yore. Men who in the old days poured the whisky and brandy down their throats order now soft drinks and ice-cream sodas as they narrate their experiences. Yet it was these hardened drinkers, men who had been drunk for weeks together, who had made the fiery liquor disappear in bucketfuls as long as there remained gold in the poke, who had the courage and self-sacrifice to vote prohibition for Alaska. They knew the harm, the evil, that came from excessive drinking; they remembered the good pals they had lost through John Barleycorn, and for the benefit of the coming generation hád the fortitude to put away the drink. They were fully aware of the deprivation it meant for them, the putting aside of lifelong habit. In this cold country, moreover, one needs stimulants, but manfully and unselfishly they trod upon the serpent of drink and crushed the fanged one out of existence, for the deliverance and betterment of their sons. And now the sourdoughs tell their stories of the great stampedes, their arduous search for gold, over fizzling soda and ginger-pop. Bacchus must assuredly roar with laughter could his spirit reappear and note the change. As Lady Astor so concisely puts it, " Drink promises heaven, but gives hell." In going on the trail in the cold weather, not one of the old-timers would ever take alcohol, or allow a tenderfoot to do so. It meant death, with the weather below zero. Had whisky been taken, imparting a false warmth, the cold would later on assert itself on the system, for, the liquor having evaporated, the constitution would be powerless to resist. The sourdough would always have his bottle of spirit, but it was not used, except in a case of emergency, until the end of the trail. Scotty Kay, who had sold liquor all his life, and who had been a hard drinker, told me he would never sell another glass. He had boys growing up, and he hoped they would not be handicapped by the curse of drink.

Having heard of another restaurant, I decide to sample it for dinner-a sourdough tells me it's all right. I enter and 
find it to be the same sort of place as the Chinaman's, but a trifle smaller. The proprietor is a sort of white man, of many mixtures, some French, and he is married to a black woman. His countenance suggests that he has been through almost everything, and he told me that he had mushed to every stampede in the country. For twenty years he had been in the North, seen Nome full of gold, been to Fortymile and Circle in their day, wandered over Dawson and Klondike, looked in at Fairbanks, and now was prepared to spend the rest of his days keeping a restaurant on the borders of the Arctic. He seemed very pleased to see me and was extremely confidential. The food he served I could not swallow. Politely I arose and paid, murmuring something about not being hungry, and as I passed out even this man showed a glint of natural human kindness. There was a faded, feeble carnation with one forlorn bloom in the window. This he picked and gave me. He possessed a certain amount of chivalry, and tried to be agreeable. This little flower was the best and all he had to give. I thanked him for his kind thought, regretting that, even to please him, I could not eat his food.

That evening for a time I sat in the public room listening to the men, who love this hard, wild country. Woe be to you if you do not find beauty in " the best land in the world," as they tell you it is. A prospector had arrived that night, having mushed for six weeks down from the Koyukuk. He had found traces of gold, but no rich pockets. We chatted, and this lean, thin-jawed man explained to me: "You ladies like to go out in the woods and pick wild-flowers. Well, we are just like you, only we like to wander all over and pick gold nuggets." It's the excitement, the wooing of Dame Chance they love, not the money, which they squander as soon as they get. It's the great gamble that keeps them chained to this mystic, cruel Northland, mushing over the trail to pick up the golden flowers in their garden of enchantment.

I am actually invited to a dinner-party. What joy! This morning, although the rain is still coming down, my spirits are made cheery, as Marshal and Mrs. Vawter have actually 


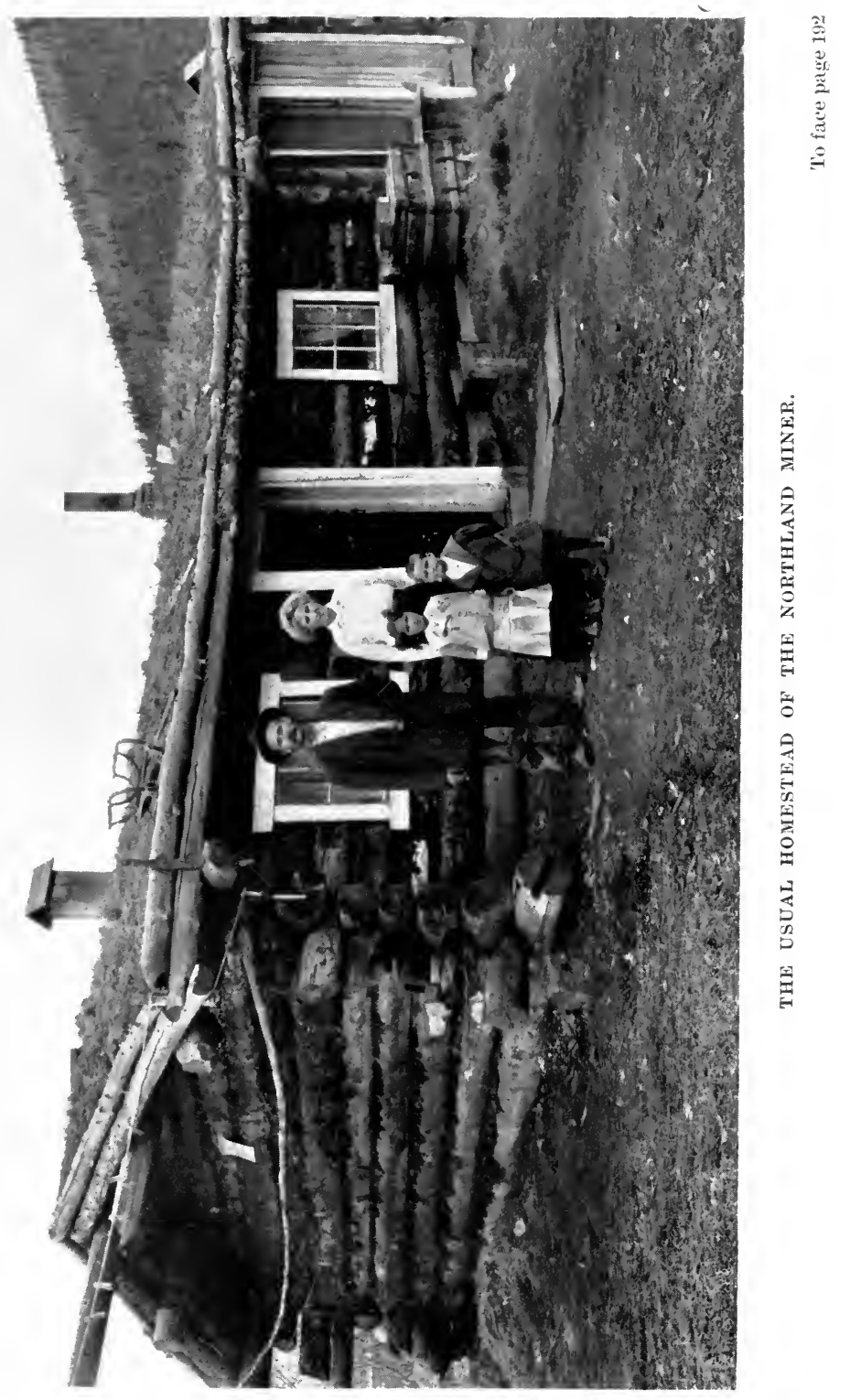



arranged for the Archdeacon and myself to dine with them and go to the cinema. Imagine society at last, even at Tanana, and what a treat not to be absolutely dependent on the Chinaman's concoctions! For fifteen days now rain has fallen; nothing to look at but sodden ground, heavy grey clouds, and the dull-coloured Yukon. It would seem that we must be in flood if the rain continues much longer, but they say that the higher bank, the one on which we are, has never yet been under water, although the opposite side has. All the vegetables in the small gardens are rotting and being washed out of the earth. The Archdeacon kindly called for me, and we set out to walk to the Marshal's. We hurried along the spongy board-walk, bordered by tall, wet, dripping weeds, and paused to look into the tiny, picturesque logchurch of St. James. It is nearly small enough to be a toy, a Lilliputian church, this house of worship away up here near the Arctic, unique in its loneliness, ever facing the rolling Tanana River. It is so pathetic and beautiful it almost evokes tears of sympathy, yet in its way it is fulfilling a grand, noble work for the people and the Indians. The Archdeacon told me he actually loved that little church built of logs, with its toy-like belfry and rather large gilded cross. The church was given by a wealthy New York lady, Mrs. Rodman, who also built the house where now dwell the Marshal and his wife. Mrs. Rodman, although a society woman, was much attached to this home on the Yukon, where she often spent the summer months. We found the Marshal and his wife most delightful people. It was a real home, and you can imagine how pleasant was the contrast after my experience of restaurants at Tanana. Mrs. Vawter served a wonderful dinner-delicious fried chicken, salad of cucumbers, tomatoes, and lettuce, and apple-pie made by our hostess; we finished up with water-melon and excellent coffee. In fact, Mrs. Vawter had herself cooked the entire tasteful dinner; my hostess was an evident past-mistress of the culinary art. It was indeed a beautiful change to once again enjoy the amenities of china, silver, and cut glass. Pleasant conversation, moreover, is such a tonic. Archdeacon Hudson 
Stuck is a brilliant, refined gentleman, an author of many standard works, a man who knows the North and the natives thoroughly. He was the first to climb that gigantic Mount McKinley, or Daneli, which he affirms is its appropriato name. Marshal Vawter told marvellous stories of the early days at Nome. He was there when gold was first discovered, when, as he said, "You could in a short time, from the sands of the beach, wash out many dollars' worth of gold. No man could be 'broke,' or need money for a meal. All he had to do was to resort to the sands, and they would repay him."

Marshal Vawter was the original of the character "Vorhees" in Rex Beach's celebrated novel "The Spoilers." Amongst the many notable achievements of the Marshal was the capture and bringing to justice of the murderer Bird. It was a celebrated case, and lasted for some time. Bird had killed a man and a woman for their gold, away off in the wilds. He was captured, and escaped, but the Marshal and others eventually found him on an island, nearly starved. They brought him back to captivity, but he succeeded in digging a hole from under his cell, and again got away. He was, however, caught after a fearful struggle, and justice overtook him in the end.

After dinner we proceeded to the cinema, where a number of Uncle Sam's boys had assembled to watch Douglas Fairbanks in " The Half-Breed," a singularly appropriate picture for this part of the globe. I felt very grateful for this most enjoyable evening.

After the deluge came the sunshine. Next morning the laggard Seattle No. 3 lay tied up at the bank, basking in the sun. When she has had her boilers inspected and "blown out," as they say, she will take some twenty men and the writer down the Yukon to St. Michael. I hope to be sailing to-morrow. It is hardly to be wondered at that the Egyptians and Incas were sun-worshippers. What a difference a burst of sunshine makes! Even Tanana strikes you, under such conditions, as not the very worst place on the globe. I start out early. The meat market afforded me much amusement. It sported a large black and white signboard. It is 
a log building, kept very clean, with its windows full of snowwhite geraniums in bloom. But there was never a scrap of meat inside. I used to joke the butcher about it. To-day as I passed he called to me, telling me to come inside, and behold, it was true, there hung a line of sausages and a goodlooking piece of frozen beef, fresh from seattle viâ St. Michael. "This will not last long," he said, " but I wanted you to know that the sign is not a delusion." Just at this season there is not much meat; it is too early to stock caribou, moose, and other game, so, unless one keeps a few fowls, king salmon, ham, bacon, and the everlasting canned vegetables, form the daily menu. Mr. Vachon has a large store here, as well as in several other Alaskan towns. He also deals extensively in furs. The people are jubilantly expecting Bishop Rowe, who will officiate at the Episcopalian Church of St. James's Mission on Sunday. Every time I pass I go into this dear little house of God. It is beautiful to sit there; the quiet and reverence of the Spirit flood one with peace. A notice reads: "St. James's Mission and ReadingRoom, open all Day and Evening. All Welcome." Now, this is a Christian idea of the Archdeacon, who insists that the Episcopalian churches all over Alaska shall be kept open. Some remonstrated, saying to him: "Hoodlums may enter, damage will occur, and perhaps prayer-books be stolen." The Archdeacon replied: "If there is damage done I will pay for it personally, but I will have my church door open to the people, so that if any desire to enter they have that privilege, and the opportunity for reflection and prayer." In my long travels over practically every country I have often remarked that all Catholic churches are open to worshippers; their doors are never locked, whilst nearly always churches of other denominations are closed. I am a Protestant, and many times in towns or cities where I was a stranger I would endeavour to enter a church simply for quiet prayer or rest, but invariably found the doors locked, a principle with which I do not agree. Surely the house of God should not turn away those who seek to pray, but should permit the followers of Christ to commune. I also declare that I do not believe 
there would be damage done to the edifices, nor prayer-books stolen. Leave the doors of all churches unlocked, and permit the people to enter and pray as they will.

The Mission Hospital of St. James's, a few miles up the river from Tanana, does excellent Christian work. Many an Indian has reason to bless this hospital and the kind ministrations of the sisters.

A visit to Tanana without having had the privilege of meeting that splendid priest, Father Jetee, whose work and lifeservice for the Indians and Catholics of the North is so widely known, would be akin to going to Rome and never entering St. Peter's. Father Jetée is the descendant of a noble family, the son of Sir Luke Jetée, of Quebec. Several of the highest clerical and educational positions have been offered to this brilliant scholar, but he pleaded for a life of simplicity, and to be allowed to devote his days to the conversion and protection of his Catholic Indians. $\mathrm{He}$ is a wonderful master of ethnology, a great student of native life. For years he has worked compounding a dictionary and a grammar of the various Indian languages, which will be handed down to posterity. In centuries to come, when the entire race of Indians will have passed into oblivion, some antiquary, delving into the past, will fortunately discover this famous key to the Indian languages, left by Father Jetée. It was so in Egypt, when the Rosetta stone was unearthed, the key which unlocked the translations enabling the lovers of Egyptology to decipher the hieroglyphics. The Catholic church over which Father Jetee presides is the smallest I have ever encountered. It is quaint and rather pitiful, humble yet divine. Softly, awesomely, I open the door of this edifice, the very spotlessness and stillness of which impress me, and I look about me. In his office, or den, leading out of the church, sat Father Jetée, his smile most courteous; a saintly, benevolent expression illumined his face. Such a character makes ordinary people feel so unworthy. I longed to talk to him, yet felt I must not encroach upon his precious time. He asked me in, desired me to be seated, so kindly that I yielded gratefully. In the small 
cubicle, or den, were well-filled book-cases and his desk. On one side of the chapel, and leading out of the den, was his box-like kitchen, for this saintly man and profound scholar works with his hands as well as with his brain, all domestic duties and cleaning being done by himself. $\mathrm{He}$ is too modest, and will not speak of his great work, but he began telling me absorbing stories of his life in the Arctic. It was a distinct privilege to listen about the trails in winter, and to hear of his dogs. If an Indian, miles away, is ill and dying, Father Jetée thinks nothing of travelling by dog-team night and day, no matter how cold or what the weather, hundreds of miles to hear the confession and give absolution to dying native or white person. All his life is dedicated to the help of others. In talking, he would smile sadly at the recollection of the behaviour of his dogs. On some occasions he had travelled as many as 66 miles a day-hard work this, as you are continually running alongside the team, jumping off and on the runners at the back of the sled, and directing the dogs. $\mathrm{He}$ described the stampede from Dawson to Nome; he was also on the trail, and they encountered more than forty dog-teams en route. The Rev. Father narrated how each team of dogs would immediately attack the other; how, in a minute, dogs, harness, and team would be in a whirling bunch, with fur flying in all directions, until the men lashed and separated them. A dog-team, he said, will never tire if they know that another team is in front of them; forgetting how tired; cold, or hungry they are, they will race to get ahead-no one can stop them. When the day's march is nearly ended, the dogs, from afar, will scent the smoke of a camp or hut; nothing will stay them; they race to arrive. They have also a curious way of training the puppies. When the winter arrives, they are taken out to see their fathers and mothers harnessed, and are allowed to run alongside for a short time. Then they are driven back. The puppies are heart-broken at this treatment, and howl with rage. Months will elapse, and when the parent dogs again start for the trail, the young dogs remember exactly what took place before, and will remain docile, and allow themselves to be harnessed, impatient to run with 
the team. Thus, in a most simple manner, they are trained for their exacting labours. I was very grateful to Father Jetée, and as he showed me out he pointed to his little garden, where the foundation logs are now laid for the erection of a reading-room given by the Knights of Columbus, who are building these recreation-rooms in Nome and other parts of Alaska. "In winter," he said, " a portion of my time is taken up in shovelling snow, so that my people can walk along this broad-walk to the church-and two or three feet of snow requires some shovelling." I felt I would like to perform this labour for him-this good man who was no longer young. He continued: "You know, we men up here in the North have to be our own housekeepers, doing our own cooking and cleaning." We shook hands and said good-bye. I don't believe I shall ever forget Father Jetée, his wonderful personality, emitting good ; his simplicity, broadness of mind, and geniality. I hope his days may be long upon the land, a blessing to his people-he who is so cheerfully giving his life's service for God. Imagine the winter scene, 50 to 70 below zero, and this holy priest, with the Divine light on his face, sweeping the walk and shovelling the snow! The wireless tower stands quite near the tiny church-overshadows it, in fact.

Upon arriving back at the Grand Hotel, I found Mr. and Mrs. Vawter and the Archdeacon, and we were invited to tea at the Marshal's-another example of the kind hearts of the North. The old proverb has it that one learns a lesson every day. I am certainly being taught several. When you think of the selfish, overfed, rich, dissatisfied women choking in the big cities, with every known luxury, and yet thoroughly unhappy, spoilt, for ever chasing prismatic rainbows which elude them, it would be an eye-opener and an antidote for poisoned lives, blinded and dulled with selfishness and over-indulgence, to come up to this country and see how some of their sisters live. "It would from many a blunder free us, and selfish notion," as Bobby Burns has it. To illustrate the character and spirit of the Northern women, Mrs. Kay, wife of "Scotty," commonly called, the mother 
of three children, the oldest about twelve, not only keeps house near by, but is the only woman to clean this hotel, where, I suppose, there are twenty to thirty rooms. She is slight, rather refined-looking, with a Madonna-like face. She prepares breakfast for her family of five at home, then comes to the hotel, wearing a fresh clean white blouse, very neat, with a dark skirt. With the help of her little girl of nine she has in a couple of hours all the beds made and the various rooms put in order. This accomplished, she goes back to her home, and cooks the dinner for the family, then washes and sews for them. Yet she never even imagines she has done anything extraordinary-simply takes this life as a matter of course. She did say to me that she thought she was getting a little bit out of things-that is, she would like to see a real good play, hear some lectures, and music. Just a slight yearning wish, but never a grumble about her present hard, uninteresting, matter-of-fact life. This woman. should be able to teach some of the malcontents, some of the selfish, aimless women, a vivid lesson, show them a panacea for their ills.

Mr. Riley Wilson, of Philadelphia, was travelling over Alaska with a party of friends some few years ago, and stayed at Tanana. He also wrote a book of his experiences, and the following burlesque on Mr. Robert Service's poem, "The Spell of the Yukon." To anyone who knows and understands this Northland, this travesty is extremely funny. Mr. Wilson's descriptions are vividly like, yet unlike, Alaska and the Yukon. It certainly shows that Mr. Wilson has a rich fund of humour, as well as being a keen observer. I render my thanks to him for this reproduction :

\section{THE HELL OF THE YUKON.}

The Devil in Hell, we are told, was chained,

Thousands of years he had there remained.

He did not complain, nor did he groan,

But he determined to have a Hell of his own

Where he could torment the souls of men,

Without being chained in a sulphur pen.

So he asked the Lord if $\mathrm{He}$ had any land

In a cooler climate a poor Devil could stand. 
The Lord said, "Yes, but it's not of much use :

It's a place called Alaska, as cold as the deuceIn fact, old boy, the country's so bare

I don't think you could make even a good Hell there.'

But the Devil said he didn't see why;

$H e$ knew his business, and would like to try.

So a bargain was made, and a deed was given, And the Lord released the Devil from prison.

We next meet the Devil far up in the North, Exploring Alaska for all he was worth.

And there from the tops of the mountains he planned To make Alaska the home of the damned,

But somewhat different from the old-fashioned Hell, Where each soul burns in a brimstone cell.

$\mathrm{He}$ knew all the arts that a wise Devil needed

To make a good Hell, so you bet he succeeded.

He filled the air with millions of gnats, Spread the Yukon River all over the Flats, Set the line of volcanoes from Unimak Pass, Bred the mosquitoes in the tundra grass.

And of all the arch-pests the imps could devise, The Yukon mosquito was a Devil's prize.

Made six months night, and sixty below, A driving wind, and a blinding snow; Six months day, of a spell now and then Too hot for the Devil, though fresh from his pen.

And over the rivers, and valleys, and plains,

Where the dew hangs low, and there's plenty of rain,

He spread wild-flowers, just for a bluff,

Old Nick sure knew how to peddle that stuff;

He turned loose the wolves to ravish the land,

Worthless set, and a ruthless band

Who crossed the dogs, made a savage pack

With ghoulish howls, that send chills up your back.

To show how well he knew the game

He next salted his new Hell claim;

He hid gold nuggets in all the streams

To lure men on in their foolish dreams, And put some more 'neath the glacial ice,

As a reformèd city hides its vice.

Then he bade Dame Rumour spread the news

To all the world and its motley crews, That there was gold in piles and piles, All the colours and all the styles.

Then he grinned a grin, a sardonic grin, And said, "Now watch the fools rush in. 
"They will fight for gold, they will steal and slay, But in the end it's me they'll pay."

$\mathrm{Oh}$, 'tis a fine land this Devil owns;

Its trails are marked with good men's bones.

The Northern Lights show clear and bright

O'er blood-red snows, though it looks pure white

To men who are crazed with the impish tunes

And the frost in the air, where you see three moons;

And so the winds roar o'er the black chapparal :

'Tis a Hell of a place he has for his Hell.

At last I am on s.s. Seattle No. 3-a good many men, but no woman except myself. Tanana fades away, but not my gratitude to Archdeacon Stuck and the Marshal Vawter and his wife. Once again floating down the Yukon. 
DOWN THE YUKON TO RUBY, NULATO, HOLY CROSS, RUSSIAN MISSION, MARSHALL, ANDREAFSKI, AND OLD HAMILTON

THE weather, as if remorseful after its continual weeping for almost a month, has fortunately changed into a June-like mood. The sun shines, and summer clouds skim across a sky of translucent blue. We arrive at Ruby, and I go ashore. During 1907 and 1910 Ruby also developed into a noted belle, much sought after by the mining world. Prospectors having found gold, the usual stampede set in. Down came the rabble, hard on the heels of the yellow enchantress. The Yukon from up-river and down-river was full of boats bringing the adventurers and their outfits. Buildings were put up in a day, and a mushroom town evolved itself. Over in her creeks men, half-crazed and excited with the love of gold, washed and panned assiduously. Bars, dance-halls, gambling-dens, shops, and hotels sprang up like magic. Some were lucky, secured the gold, and left the country with their treasure. One man was supposed to have amassed 90,000 dollars in a few months-the same old story repeated by many a mining camp all over the world. Everything boomed for a time, and now this former El Dorado is absolutely dead, although a comparative infant in years-a decaying, hopeless place. The houses, or most of them, are of corrugated iron, with a few frame buildings scattered at intervals. A good push, and I am sure they would tumble down. In the muddy roads, tin pans, bottles, old sacking, and other refuse, was thrown about without regard to order and cleanliness. As you walk on the rotting wooden sidewalks, you must pick your way carefully, for the boards are full of holes, certain invitation for a twisted ankle. Shops are closed, and, peering 


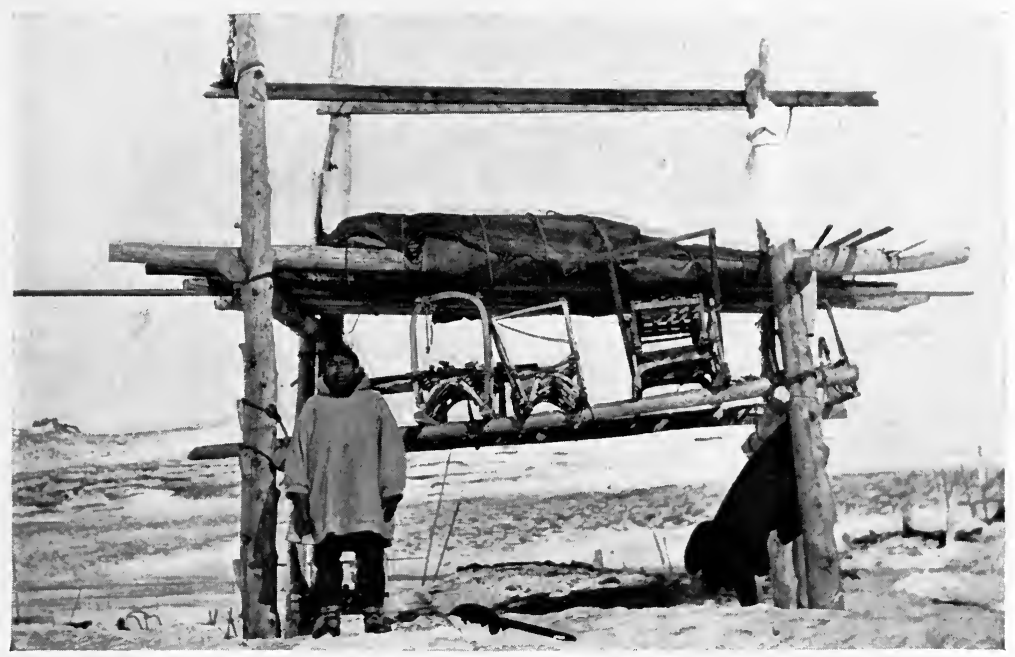

A CACHE FOR GUARDING FOOD: ESKIMO.

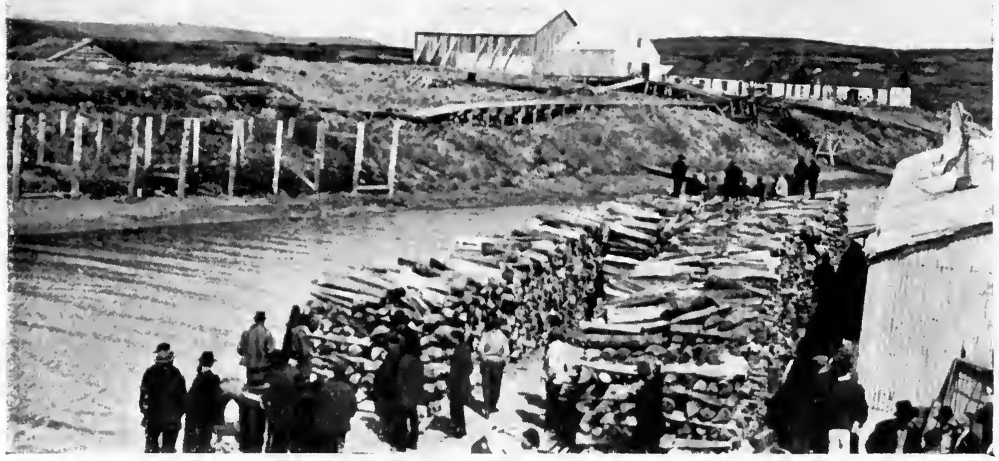

TYPICAL LANDING-PLACE AND WOOD PILE, ANDREAFSKI, YUKON RIVER. 

inside, you see merchandise, which must have cost a lot of money to bring this great distance, now abandoned. Cases are packed and labelled, but in many instances their owners have not had sufficient money to take them out of the country. In one shop an expensive printing press was to be seen; type founts and type-cases lay scattered about on the floor and in piles. One presumed that the owner had received some call which had obliged him to quit most urgently. It was this way all over Ruby, as if an earthquake or a plague had visited the place, and everyone had forsaken it. The headquarters of the Northern Commercial Co. was the only building that wore an aspect of prosperity. In what was once the main thoroughfare one reads such signs as " Capewell's Hotel "' and "The Williams" - most dreary, neglected places. U.S. Commissioner's is closed. At the I aw Office a sign invited one to "Walk in," but all the steps had rotted away. The ginshop and the "Traction Cafe" "- these tumbledown buildings had also had their day. It was too sad, roaming around this desolate, forsaken town. There was nothing interesting to see or do, therefore I picked my way through the mud and decay back to Seattle No. 3. On the bank a row of huskies stood patiently awaiting the kindness of the cook to throw them bits of food. Other dogs were curled up or hibernating in mud-holes, too listless even to take their turn for eatables.

People said that the men-folk were working on the creeks in a radius of 50 miles, but the rich old days of "Long" and " Poor Man," where giant fortunes were formerly made, are now luscious memories. Rumour speaks of a man who in the golden days had been most successful, and who still optimistically " carries on," although last year it cost to mine his property 3,000 dollars, and this year he will spend 6,000 dollars in a similar quest-a losing game, even to the most hopeful. There being nothing to amuse the children of Ruby, as a treat they come on board the boat to look over the strangers, and get a breath of news from the "outside." Very interesting were these girls and boys.. Their ages varied from ten to fourteen, and all were Northern born, some hailing from Dawson, some from Nome and Fairbanks. Many 
had never seen a motor-car, none had been out of the country. They were eager to talk, and questioned me about England, which they had read of and longed to see. Then they began telling their news, intimating that their respective families were thinking of moving to a more prosperous part of Alaska. The only evidence of up-to-dateness was the saw-mill and timber-yard. We took quite a cargo of wood on board17,000 feet of lumber. Some dog-sleds piled on the bank reminded one of their winter sports. These sleds were built with high backs and a sort of crude break made of iron with four prongs, which would hold fast in the ice and snow. Sitting on our narrowing deck space, because of the encroachment of the lumber, it was amusing to watch the mixed crew coiling and recoiling thick ropes, hauling freight, rearranging logs, and piling up tier upon tier of canned-milk boxes. We must have conveyed thousands of "Carnation" brand along this river to every part of Alaska. The crew consists of halfbreeds, Indians, and a few Japanese and Chinese. One half-breed evidently considered himself a dude, for he worked in a pair of leather gauntlets thickly embroidered in beads. (I happened to be in the general store at Tanana when he bought them.) The foreman screams out his commands; it calls for a certain amount of skill to manipulate the three huge barges, packed to their full capacity, which we are taking on here to push to another destination lower down the Yukon. As I look upon ugly, desolate, inappropriately-named Ruby, a thought comes over me: "What a blessing a cleansing fire would be if it did but wipe out this dead, listless town !" On the opposite side of deserted Ruby is God's lovely land, untouched. Along the green banks are feathery trees, backed by the beautiful mountains, a symphony of blues and purples. A perfect summer sky, flecked with ethereal clouds, completes the picture which Nature has painted, and the scene is faithfully reflected in the tranquil waters of the Yukon. On the one side the perfect work of God, on the other a rotting, devastated mining camp, built by the greedy hand of man. 


\section{NoLATO.}

Nulato is 291 miles below Tanana. It is famous for its Indian cemetery, described by most as undeniably curious. I had made up my mind that if I had to sit up all night I must arrange to go ashore and investigate this much-talked-of God's acre. It was about 3.30 a.m., and rather dark, when we drew up at Nulato. Six weeks have elapsed since the longest day, and one notices the difference in the intensity of the sun and the shortening of the days. It is quite a change from being on the Arctic Circle; for now we have a few hours which might correctly take their place as night. We have passed the mouth of the Koyukuk River, which district, many assert, will be the scene of the next gold stampede. We, as a matter of fact, have brought along several mushers, whose object is to prospect the Koyukuk country, which is said to be the most hospitable camp in the North. On a high promontory stands a large cross, marking the spot where a Catholic Archbishop was years ago murdered by the Indians. This bluff is named Bishop's Mountain. Nulato has had a history of massacre and bloodshed since 1838, when it was established by a Russian, Malakof by name. The Indians have fought over and over again for Nulato, and bitter has been the warfare. It was here that Lieutenant Barnard, of the British warship Enterprise, was murdered by the Indians in 1851. He was sent up in search of news of Sir John Franklin, the Arctic explorer, but unfortunately, in sending for the chief, he offended the Indians, who slew him in a general massacre. Over the grave of this British officer is a cross marked :

Lieutenant J. J. Barnard, Of H.M.S. Enterprise.

Killed Feb. 16, 1851, by the

Koyukuk Indians.

Unquestionably the Indians were mighty cruel in their primitive state, and it was said that in this part cannibalism flourished openly. Another noted explorer and naturalist, who was sent out in 1861 by the Western Union Telegraph 
Co., met his death at Nulato. He was Robert Kennicutt, and his mission was to survey a route by Alaska and Siberia to Europe.

In the dim light of dawn the sloping mountain-side upon which the Indians are buried looks peculiarly weird from the deck of the steamer, as we glide silently under its lee side. Upon closer inspection you observe that the whole slope is a mass of shining mirrors which gleam with decidedly uncanny effect. We draw up at Nulato itself, a small village with the usual stores, a native school, and a scattering of houses. I made my way as quickly as possible to the cemetery. It is difficult of access, as there is a narrow slough which must be crossed by boat, then a stiff climb of at least ten minutes before you arrive at the graveyard proper. It is certainly remarkable, this sacred Indian resting-place perched upon a high, rocky promontory with innumerable graves extending down the sides. It resembles the Chinese fashion of burying their dead at a point whence a good view is obtainable. If those Indians who have fought and bled, and who now repose on the hallowed mountain-side-if these dead warriors could see, their eyes would feast upon a rich panorama of the Yukon River. To convey the dead to these heights must have been a tiresome task; and even to this day canoes occasionally arrive with the relatives of the departed, who have requested to be laid in this remarkable cemetery. The graves are covered with miniature houses, a sort of chicken-coop which is erected over the receptacle containing the remains. These coverings are painted in every conceivable colour. The roof may be a vivid green, whilst the sides will be orange or scarlet. Bright cobalt-blue seems to be a favourite. Then birds, animals, and fish, reproduced most crudely, will decorate some of the narrow structures. They are also fond of crosses, wonderfully painted and carved according to Indian art, and poles of various designs. These emblems are supposed to keep away lurking evil spirits. The poles, it should be added, bear no resemblance to the totem-poles of Wrangel, Ketchikan, and South-Eastern Alaska. Obviously different tribes have other methods of honouring their dead. On the 
roofs of the graves are laid many mirrors, which flash in the sunshine, and various belongings of the dead, including guns, snow-shoes, bags of tobacco-in fact, anything which they treasured in their lifetime. This miscellaneous collection of offerings, the strange colours, coops, crosses, and poles, the dim half-light with a faint streak of rose indicating the approach of dawn, produced in my mind a unique and unforgettable experience. The Indians believe "Happy are the dead who sleep on their reverenced mountain-side."

I have to hurry back, as the boat only stops a short time, and already her siren breaks the uncanny silence of this happy Indian hunting-ground.

A few miles below we pass Kaltag, a Government post and trading station. All about this location herds of reindeer are supposed to be visible; some of the largest herds in Alaska congregate here in winter. As we do not espy any herds, it is presumed that they are grazing on lands farther northward. The lower reaches of the Yukon vary as to scenery and local life; the halting-places become smaller and more primitive, the country flat, the river muddy and ever wider. The objects of interest are simply Indians living in solitary tents, attending to their fish-wheels, cutting up and drying the salmon, and feeding the dogs. The enormous wood piles, the $\operatorname{logs}$ to be hauled up or down river as necessity requires, the mosquito-netted wood-chopper resting from his labours, eager to gaze upon the steamer, signs of life to his lonely eyesthese were the daily recurrent scenes. Life on board the Seattle No. 3 became slightly monotonous. We have not on this boat such comfort as fell to us on her sister-crafts. She is an old steamer built for the transit of miners in the stampede days. Most of the cabins have three berths, one above the other, and it can be imagined there is none too much space for the unfortunate passenger. Some of the big men complain that they can't turn over! Personally speaking, I am comfortable enough. My cabin I have to myself. There are but two berths, but the washing arrangements are crude and dingy. There is a notice issued by the company and exhibited in every cabin; I was rather amused at this 
announcement, the like of which I had not encountered before in my many voyages.

"Passengers must not at any time, nor under any conditions, lie in their berths with their boots on."

Considering this is not a habit of mine, I need not fear for the consequences, but it shows the class of people who must at times frequent these boats. I am the only woman on board, but that is hardly unusual, because women do travel up and down the Yukon, although in very scanty numbers, and it is a long run. There are some thirty men, all miners, prospectors, business men. I am the only creature on board who is travelling for pleasure. The men, although weary with the uneventful life on the boat, never fail to be courteous, and treat a woman with every respect-they are evidently glad to see one. First one tells you of his experiences, then another will lounge up to you, take a seat, and his tale will be told. I can tell the stories now myself, for they vary little. There is all the scandal of the squaw-manthat is, a white man living with an Indian woman; and, strange to relate, in these mixed family connections the white man will invariably drift down to the level of the native wife. $\mathrm{He}$ loses ambition, self-respect, lets himself go, and in a few years is just like a native. It is difficult to realize this, but it is true. When first I entered at Skagway the Land of the North, I listened entranced, and with widening eyes, to the stories of love, adventure, and, in many cases, remorse, until now naturally I feel a little surfeited with sourdough revelations. Perhaps I am a trifle homesick, and repetition lacks appreciation; satiety evokes boredom. Some of the men-folk are dressed roughly, some wear no collar-a flannel or buckskin shirt is their one upper garment-their way of speech is not ours, but they are big-hearted, kindly, and one must bear in mind that one is travelling with frontiermen who are making Alaskan history. These men "blaze the trail " and open up this great land of unending surprises. The hard life, the continuous fighting with the rigorous climate, has turned out splendid physical types of men. A good woman is sacred 
and raised to a pedestal, and it is her fault if she does not retain that position. A young girl would be far safer travelling in this part of the world with the so-called "rough men" than she would be in the great cities. Strong fists guard honour, strong arms mete out protection and justice amongst these stalwart Alaskans. It would be a blessing were the girls of Great Britain and of the East of America to have a chance of meeting, helping, and sweetening the lonely lives of these pioneers who are opening up uncounted miles of virgin hinterlands to commerce, and for the benefit of humanity and the world. Alaska is passing rich in possibilities. In the future good motor roads and railways will connect up with the mighty rivers and lakes, homes will spring into being, and, blessed by Mother Earth, will cradle generations yet to come. Alaska needs women - not a few, but thousands; and women coming out to this country will find that golden hearts are beating 'neath the buckskin shirts. The great cry of Alaska is for women.

\section{Holy Cross.}

A really hot day. If one studies the map it will be seen that for some time we have been coming south. The wonderful Yukon still widens, but diminishes in beauty. I am now becoming very well acquainted with this Queen river of the North, which has carried me along on its rush for 2,000 miles in its seeming haste to join the sea. Looking back to the day when I first beheld its birth away up there on the summit of the White Pass, a half-frozen pool choked with dirty snow and ice, and where they told me "This is a tributary, or where the Yukon begins," I cannot but be amazed, fascinated, and finally fondly proud of this noble river. One could never believe a river could offer so great a diversity of scenery and character. From a puny, ugly infant, I have watched its development, as a godmother watches over a beloved child. I have admired its precocious ways as a merry youngster romping and playing hide-and-seek between high bulwarks of rock; leading boats on, like a frolicsome schoolchild, into what appeared a mazy labyrinth; then merrily 
pretending to be a lake, but pointing a way out by a mysterious, obscured turn, and forcing a channel around a sheltered corner. Again, I have witnessed its spirit of riotous frolicvery mad and unreasonable-about Miles Canyon and the Five-Fingered and Rink Rapids, sowing the wild oats of youth, tumultuous. Then began its development into a beauty, challenging all rivals as it neared the Arctic Circle. Came a mien far more sober after giving birth to its children -Eagle, Fortymile, Circle, Fort Yukon, and Tanana-carefully watering their banks, tending their needs, bringing on her ample bosom food and merchandise for their several wants. Now, alas! she grows more like a passée lady, losing her beauty, going to flesh, broadening out and eventually following her destiny-a grave and oblivion in the Bering Sea. The eternal evolution, everything and everyone following the Divine guidance of the Great Master's hand.

I now land at Holy Cross, which has a more prosperous air. If you are desirous of visiting the Iditerod country, you transfer from this settlement to a smaller boat going up the Iditerod River, where also they are mushing for gold. It is quite a relief that at Holy Cross there are other subjects and other interests than the continuous talk of the eternal gold. Holy Cross nestles in the lap of high wooden slopes, and its large white cross attracts attention from afar. I walked up to the Catholic Mission, as Father Jetée had assured me I should find it interesting. There are about 300 Indians and half-breeds in this settlement, which was established thirty years ago. On my way I met some of the children, their features denoting many an admixture-Indian, Russian, Eskimo-but especially remarkable was the fairness and blond hair that told of Swedish and Norwegian blood. Some had locks that were almost white. Many Swedish miners come out here to the North country and settle down with a squawwife, quite naturally and contentedly. It soon became apparent that there was a good influence at work here, for they greeted me with a pleasant word and an inbred courtesy, then smilingly held out small bouquets of fire-weed and bluebells. They directed me to their church, the Church of the 
Holy Family, where I found a priest who kindly offered to show me the locality. "Are you a Catholic?" inquired the priest. I replied : "I am not, but I have the greatest respect and admiration for Catholicism." In my travels in wildest Africa, South America, China, and every part of the world, I have seen the good work which the Roman Catholic Church accomplishes, and, as I have already said, their doors are never closed; you can rest or pray in their buildings at will. Of all the Catholic missions I have visited - and there are manythe old missions in California were most beautiful. I have always found their clergy courteous, Christian, glad to show you their work, and most tolerant, even if you do not happen to belong to their Church. I went into the holy edifice with the Father. Its interior was spacious, well proportioned, and nicely fitted up. This priest had devoted nineteen years of his life to the Indians, and would pass the rest of his days here. We talked on, and his face darkened as he related how the greatly revered Bishop Seghers (he who established this mission) was foully murdered by the Indians in the early, tempestuous days. The Bishop was in a canoe with his Indian servant, coming down the river. It was on a fine October day. They were obliged to stop the night in an open shed, where the salmon hung drying, at the foot of Bishop Mountain. In the morning, without cause or explanation, the Indian raised his gun to the helpless Bishop's forehead, and treacherously shot him. Then he tore the gold cross from his victim's neck, spat upon it, and defiled it. As already described, a cross marks the spot of the tragedy. Yet the priests were not to be intimidated by this terrible tragedy, for more came out from the world of men to carry on the Christian work and enlighten the Indians.

We then inspected the well-built schools, hospital, and the convent where the sisters care for and teach the children. The Mother Superior, sweet-faced and genial, now took me in charge, and we went over the establishment together. Eight nuns have dedicated their lives to these Indian children, teaching them how to make their own and the boys' clothes, instructing them in gardening, cleaning, cooking, elemen- 
tary knowledge, and religion. Even these children, so far away from the dust of conflict, helped the Red Cross by knitting seventy pairs of socks and several sweaters for the soldiers then in France. I passed through the dormitories where the girls slept. Their beds and pillows were covered with pink calico sheets; the pillows were stuffed with the down and feathers-gathered by the children-of the birds who migrate here. Every child had her own agate washbowl, with towel neatly folded beneath it. A very long, large stove-pipe ran through this part of the building, and the sister explained that the pipe, although unbeautiful, was necessary for heat, as in the winter months the temperature often registered 58 below zero. That day, she said, was the warmest day they would probably have this summer, and the thermometer then stood at 86 degrees. I was shown some artistic drawings and pretty original picture-frames fashioned out of rustic twigs, and other work, evidence of the cleverness and ingenuity of these children, 100 of whom-boys and girls -were being cared for and shown the way of making a living and a better path in life.

I apologized to the sisters for taking up their time, but as they see very few people in the year-and never a stranger during their enforced isolation during the winter-they assured me it was a treat for them to meet me. Previously I had heard a stealthy movement of chairs and some slight confusion in the next room. The Mother-Superior asked me to step in, and I was pleasantly astonished to find the entire school, boys and girls, standing, every hand aloft, and waving an American Flag. Across the wide blackboard was the flaming inscription " WeLcome," written with many flourishes in chalk of mauve and white. Then these young people rendered a "Welcome" song, the words of which were simple, but perfectly enunciated. I sat beside the nuns on the raised platform. The children's eyes were fixed on me, and my curious eyes on them; there were ranged on one side girls from five years of age up to fifteen; the younger ones were bare-footed, their faces shining with soap and expectancy, their hair fresh from the effect of brushing, their 


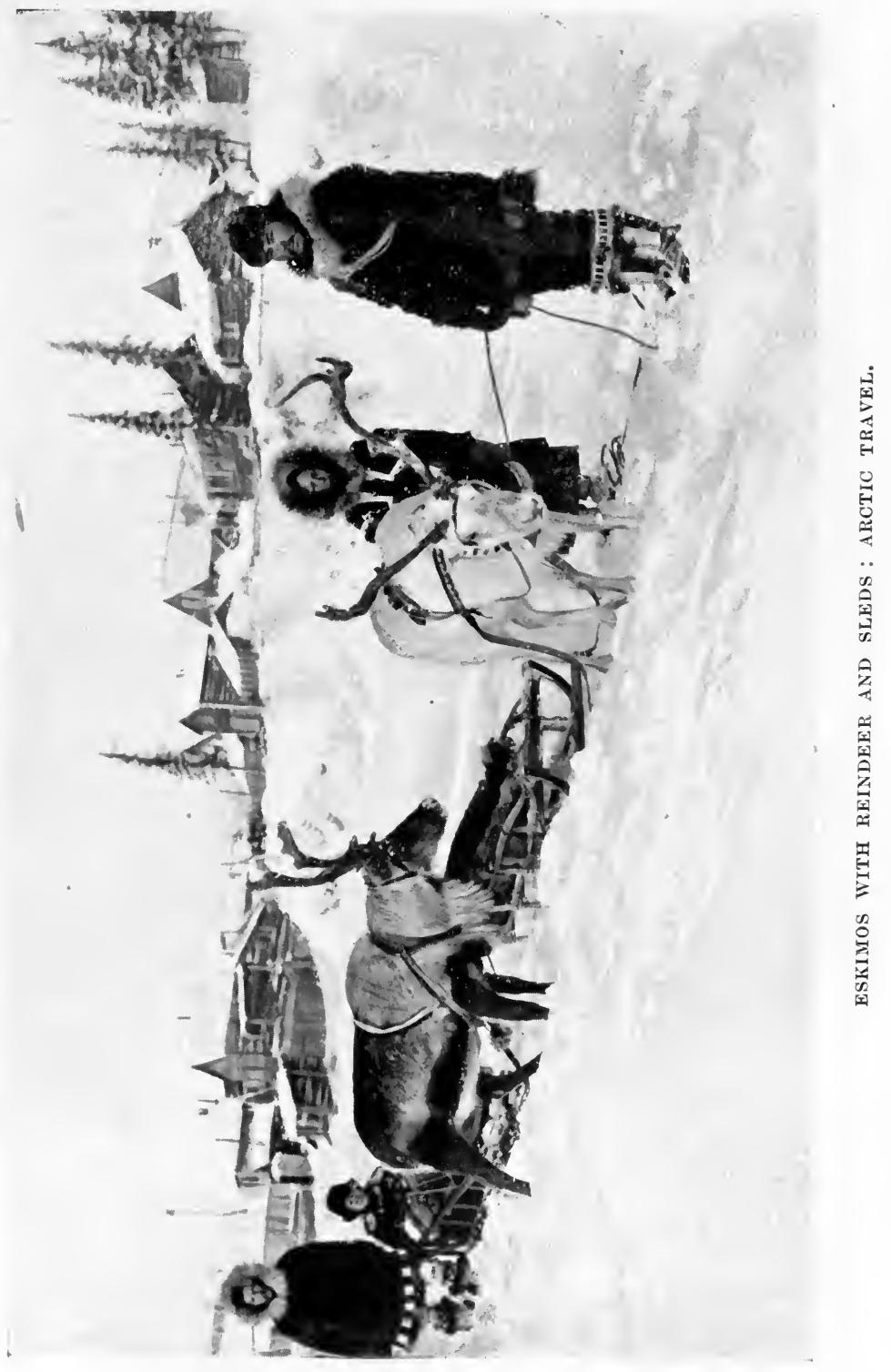

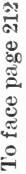



cheerful smiles mirrored the joy of life-life the miraculous, whether in wedlock or without, just life, that atom beyond the purchase of the greatest millionaire, but which the Divine One planted in these blossoms of Nature to bring forthwhat? There they-stood, the Mother-Superior beside the open window, the white curtains fluttering in the fresh Alaskan breeze, drumming out the tune on an old piano, her benevolent face framed by her white head-dress, the children keenly intent on the unusual stranger, their faces beaming with smiles of greeting. It was a wonderfully delightful picture which will linger in my memory.

I lowered my eyes; they were full of tears. The simplicity, the kindness, the pathos, of these children of all sorts of colours and mixtures, singing their praises to God, played on my very heartstrings. The self-sacrifice of the sisters, the noble work of this Catholic Mission at Holy Cross, is really sublime. Afterwards some of the children escorted me to the steamer, showing me on the way acres of gardens under cultivation : potatoes, lettuce, vegetables of all kinds, and a variety of flowers.

On the river-bank is an old steamer named the Oil City, moored to the bank, and the only " hotel " the place affords. Another boat of interest that one passes is the St. Joseph. This belongs to the mission, and, I should say, is the most unique boat in commission. It also has a mission, and that is it is sent once a year to St. Michael to bring the annual supply of provisions for Holy Cross. The commander of the St. Joseph is a pure-bred Indian, and the engineer is a laybrother, formerly a rich man of Philadelphia, who felt the call and laid down his affairs, renounced the social world to enter the religious. How much happiness it would give to some American millionaire, whose millions accumulate like a snowball rolling downhill, to donate just a little to the Mission of the Holy Cross, situated on the Yukon River, 300 miles from St. Michael! It would merit a jewel in his heavenly crown. 


\section{RUSSIAN Mission.}

Another deserted place, a few scattered houses, a store, some hovels and tents, howling, hungry dogs, and that's about all. We throw off the mail-bag. A short distance from the Yukon's bank stood a good-sized Russian Greek church, which must have represented a substantial sum when erected in the days when the Autocrat of all the Russias ruled this distant colony. The church was locked and the door boarded, but by looking through the windows you could see the tinselled altar, embellished with paper roses, and on the walls various paintings of the Saints. Everything was dusty, and it would seem that the church had remained untended for many a day. The church will probably remain in its forsaken condition until it falls down from sheer decay. These places of worship and the ground they stand upon still belong to Russia, by the terms of treaty when the U.S.A. purchased the territory; and as the fate of that empire is in the hands of the Bolsheviks, it is presumable that no one will ever bother about a few desolate, crumbling churches scattered along the mud-banks of the Lower Yukon.

\section{MarshaLl.}

One afternoon we paused at Marshall. A queer-looking village, the few houses and warehouses dotted about on the sloping land give the impression that they have been bombarded. Most of these buildings are travellers, inasmuch as, when there was a stampede up the neighbouring small river four years ago, prospectors did not wait to build, but took the required buildings from St. Michael, and moved them on barges up to Marshall. These buildings soon flourished as stores, hotels, and principally bars. No one had the time, or the thought, to paint them, and no one has bothered since; hence their mottled appearance. The country round about consists of rolling green hills. I watched in the hope of glimpsing the reindeer, but evidently the herds were then feeding on the mossy lands to the north. Ever since Nulato we have been on the look out for reindeer, but as yet not one 
has been discovered. One of the prominent landmarks is a big corrugated iron warehouse where hundreds of gallons of oil are stored. I sauntered into the emporium, or general shop, of this bizarre frontier town, and found it a real treasure-box in the way of Eskimo and Indian curios. Dogharness hung beside great breasts of pure white swansdown, beautifully soft and fleecy. I had never seen such lengthy strips. Furs in all colours, red fox, musk-rat, wolverine, lynx, bear, and martin, lined one part of the shop, whilst enormous stores of canned goods were piled on the other side. I was shown hanging pockets made of the intestines of the walrus and whale. The skin is thoroughly cleaned and dressed to look like oilskin, then beautifully sewn and trimmed with swansdown in tufts, and bordered with red fox. This unique souvenir drew money from my purse. Dozens of pairs of moccasins to suit all tastes, and in all sizes, were made of hair-seal, white fox, and reindeer skins. The edges of the tanned white skin of moose which is used for the sole bear the frilled or shirred marks of the Eskimo women's teeth! They chew the skins to make them more pliable! Eskimo women, be it added, usually have fine white teeth; a bride is chosen for her white and serviceable molars, that being the special mark of beauty the Eskimo appreciates most. These moccasins are the most comfortable footwear imaginable; they are soft and warm, lined with fur, and bound with beaver, or a variety of other skins. Some were beaded, and on others considerable decorative skill was displayed, such as ornaments of flowers made of split and dyed porcupine quills, looking as if woven of silken threads. Here, also, were the first mukluks I had ever seen. These are longlegged, with a sort of moccasin-shaped foot, which is usually stuffed with soft hay or grass to keep the foot warm. The upper portion is made of the skin of the reindeer, often sewn in pretty designs of brown stripes alternating with white. Mukluks, invariably worn by both men and women throughout the Arctic, are tied on the ankles by strips of reindeer skin. Nothing equals them for the wet trail, whilst the moccasins for the dry and for snow-shoeing are the most 
sensible of footgear. How much more appropriate and comfortable than the smart patent leather with 3 inches of heel, which compel women of fashion to walk on their toes and distort the natural foot, with almost as much suffering as the bound extremities of the "heathen" Chinee! Bags were to be bought made of swan's feet, softened into velvet by the clever tanning of the women. They were trimmed at the top with red leather and draw-strings of skin, and were finished off with fur balls of mink and swansdown. I saw vests and breeches made of the hair-seal. They told me that equipped in these breeches, good mukluks, and a fur parka, the Eskimo could lie out on the ice-blocks for hours waiting to spear a whale or walrus without feeling the cold. As usual, all the inhabitants of Marshall have arrived, and most of them are in this store. There is a deal of chatter, of which I do not understand a word, and eyes are wide with astonishment at the sight of a strange white woman. The influenza this spring was especially cruel to the natives. The storekeeper told me dreadful stories of how they had suffered because of insufficient heat and food. There were two white women at Marshall with whom I talked. Then we called upon a good-looking trader who was married to a half-breed girl of sixteen. Here also was another man who claimed to be the first white pilot of the Yukon. He was chock full of reminiscences. Afterwards they told me he was a great squaw-man-in fact, he had squaws and half-breed children all along the Lower Yukon. This was especially amusing, remembering that he insisted upon talking to me about women's suffrage !

Society is getting a little mixed about here. It does not require much time to exhaust the interest of these so-called towns, and when the steam whistle summoned us back to Seattle No. 3 I was not loath to bid adieu to Marshall. The mosquitoes were troublesome enough, but now we have the gnats as well-tiny black insects which make straight for the eyes and penetrate the average veil. We are now below timber-line, not a tree to infuse life into the flat landscape; no more wood piles-in fact, we are taking wood to the people 
of St. Michael. Again we glide down the ever-widening Yukon, past the huge Carlisle Cannery Co., where are hundreds of workers living in tents. It is like a stampede citystores, laundry, pool-rooms, shoe-shops, all are under canvas like a military encampment. The salmon cannery is conducted upon several two-storied barges, which are fitted out with the latest devices, and king salmon is soon rushed through, from a big lordly fish, into dozens of prosaic cans; 6,000 dollars were paid for freight alone on one shipment. Some 300 people are employed while the season lasts, about 100 of them Japanese. The Indians are hostile to the canneries, for they assert that the canneries get all the salmon, that their fish-boxes are empty, and that the supply for themselves and their dogs is insufficient. This is rather hard, because they depend upon the salmon for a meagre living, and if that staff of life is taken from them they must die out as a race. Comparatively speaking, there are very few Indians left as it is. The clergy also insist that the Government should protect the salmon for the Indians, or that at least enough should be allowed for them to live upon, as neither they nor the dogs could exist in winter without this important staple. Of course, the cannery people claim that it is the fault of the Indian; that he is too lazy to attend to his salmonwheels. In the Indian tents that I visited all along the Yukon-and they were numerous-I found the Indians gentle, patient, kindly people, rather sad in temperament. Many are of the Roman Catholic faith. Some, it is true, were dirty, but most of them-the women-kept their tents clean; some had even arranged wild-flowers in tin cans to impart a homelike touch to their tents. They have attended the mission schools in their early days, and from the sisters have imbibed their refined ideas. They are most glad to see you, talk of their families, and tell you whether they have a good husband or a cruel, lazy partner. They will confide in you all their innermost domestic affairs. 


\section{ANDREAFSKI.}

Many a time, in looking at my map, I had judged Andreafski, by its portentous name and Russian history, to be a much more imposing place than it turned out to be. I was more than disappointed at the smallness of the settlement, with its one row of little white houses with red roofs. Andreafski was founded by the Russians in 1853, when it was made quite an important centre, with barracks, shops, and so forth. The Indians appeared friendly, but, watching their opportunity when some of the officials were away, they ferociously attacked and massacred nearly all the Russians. But retribution followed ; other Russians arrived, and a big battle was fought, which practically eliminated the Indians from that locality. For years afterward the Indians would not venture near Andreafski. There appeared nothing whatever to do at this deserted spot, once so popular with the Russians. One cannot but speculate as to where are the souls which only a few years ago, comparatively speaking, called Andreafski " home." Now the vilest variety of mosquitoes are' "at home" here, and for companions they have mighty legions of gnats. Some of the men and I went on shore with the mail, where we had anything but a welcome reception. The dogs snarled and snapped at us, the sun glowed hotly upon us, and the torture of the insects drove us back on board. We were glad to leave Andreafski to the mosquitoes and their allies the gnats, although we all brought away the scars of our attempted invasion of their colony. A few were so hostile that they not only chased us away, but, following us, again assailed us with renewed intensity.

\section{OLd Hamilton.}

Weather cold and foggy. We are nearly out at Norton Sound, the last stop on the now broad Yukon, which looks more like a sea-the delta is 100 miles wide-than a river. All is flat and marsh land, and the resultant picture is dreary. Wood has to be stacked here for the boats leaving for upriver. Driftwood is continually floating down-stream, and 
this is eagerly retrieved by the natives for their fuel. We have also left the Indians behind us ; this is my first acquaintance with a real Eskimo village. The U.S. Government have established a native school, and a tiny Catholic church raises its humble, unpainted cross skyward. Some of our passengers are in Edwards' General Store, and I also go in to see if there are any curios. These stores have much the same appearance, but you never know what you may pick up. This is a fact which I have often proved by looking into the back portion of the shops. It was, however, a surprise to find hanging with a miscellaneous lot of furs, a long rainproof coat, or parka, made entirely of the tanned intestines of the whale. The garment was finely sewn and decorated with fringes of feathers of native birds, imparting to the parka a most droll appearance. This garment the Eskimos wear in wet weather over their fur parka to keep the fur dry, and as these skins are waterproof, they afford a certain amount of warmth as well. It certainly proves that the Eskimos exercise ingenuity in making use of everything put into their hands by Nature. Patchwork rugs made of all the Arctic furs were effective, and walrus tusks, brown with age, having been buried for centuries, were on sale. Usually these tusks are cut into various souvenirs-rings for serviettes, bracelets, cribbage-boards, and utilized in jewellery of every description. Whilst I was making a few purchases, an Eskimo woman rather prettily approached me, and said in her odd manner that she would show me her igloo, or home. This woman had straight jet-black hair, which she wore parted in the middle, and two braids hung each side of her ears $\dot{a}$ la Gretchen. Her black eyes smiled kindly at me; her teeth, sound and white, must have put her into the belle class with the male natives, and her complexion was clear, with bright red cheeks. Her colour was perfectly natural, but so vivid one might think she had recourse to the rouge-pot. She was no darker than an Englishwoman returning from a holiday by the seaside. Laughing continually-I presume at my strangeness-she appeared perfectly happy. She motioned, and I followed her out of the shop and towards her home. 
We passed the frame school-house belonging to Uncle Sam -it was painted green with white facings-and left the Catholic mission church behind. This mission church is a branch of the Jesuit Mission at Holy Cross. We kept wandering on, passing tiny houses that were made of anything they could find-logs, boards, corrugated iron, and tents. The houses would consist of just one small room in which many lived. Some had thatched their roofs with mud from which grass flourished luxuriantly, imparting a queer aspect to the house. I began to wonder where my guide was taking me, for we had left the village and turned a corner, but the woman still smiled and beckoned me to come on. I had always heard that these Eskimos were quite gentle and never harmed one, but nevertheless I hardly cared to go too far with my new acquaintance. We went on until a tent loomed up against a green bank. This small, dirty tent she pointed to with as much pride and glee as if showing me Buckingham Palace. Inside was a damp mud floor, and on a bundle of odorous rags a small black, wolf-like puppy slept. This was her treasure which she wished me to take. I declined. It was difficult enough travelling in the Arctic by oneself, without being burdened with a small Arctic puppy; and fully 15,000 miles separated me from my London home. It was appalling to see the lack of everything that would make for comfort in this poor creature's abode. No wonder they died off like flies when influenza overtook them. There were some boards on the water-soaked inud floor, and on these was a sort of bulging mattress of down, and some pillows. They find the real eiderdown-in these parts and collect it. A tiny stove, red with rust, no chairs, no table; this was her home. Never had I dreamed that one could live in such primitive, cold, uncomfortable surroundings. The wind must have howled about that flimsy tent, and the nights would be perishingly cold. I paid her what she demanded for a swansdown hanging pocket. One could not bargain with a woman who had nothing. Then, refusing the puppy, we walked back. On the way we were joined by a girl, the woman's daughter, suffering from some terrible disease of the hip, and 
looking consumptive. She limped along painfully with us. My first Eskimo call was anything but exciting. On the bank I met the only white woman residing at Old Hamilton, Mrs. Frohock, a charming little American who assists her husband in teaching at the school. She was most delighted to meet me, saying she had not seen a white woman for a year. Just imagine the enforced isolation for this bright, well-read woman. She invited me into the school, part of which forms their home, and introduced me to her husband, the school-teacher, also to her two boys, aged seven and eight respectively. Here I found our genial fellow-passenger, Father Sifton, who is making his annual round of visits to the various missions in this unfrequented part of the world, where summer is brief and winter unduly long. We all sat down in the small living-room, the floor of which, as well as the tiny kitchen outside, had been freshly painted. Our hostess had to spread newspapers to keep the paint from sticking to our boots. I remained quiet, listening attentively to the annual news gossip between Mr. and Mrs. Frohock and Father Sifton. Mr. Frohock was telling about the dread influenza in this cruel frozen zone. The entire settlement of Eskimos comprises only sixty-five souls, and out of that number thirty succumbed to the illness. The Government doctor, a noble fellow, had just started by dog-team for the " outside," on leave, but hearing that influenza had broken out amongst the natives, turned back to do his duty. Immediately upon arrival he took the disease, and although Mrs. Frohock worked with almost superhuman energy-as her boys were both down with the illness-the doctor passed to the long trail. Therefore, there was now no medical assistance, just the simple remedies that Mr. Frohock had by him, and all the natives ill unto death. No help could be expected in that frozen, snow-piled land; the temperature crawled to 68 below zero, and rested there. Imagine these cold, comfortless igloos, no one to help them except the school-teacher and his wife, and they worked with all their power on this Herculean job, and great were the difficulties they encountered. They opened their small kitchen to everyone. Mrs. 
Frohock cooked unceasingly, utilizing all the provisions out of her limited store, and supplied the natives with hot drinks in the shape of tea and coffee. They had enormous difficulties with the inborn superstition of the Eskimo, for the natives have a horror of dead bodies, and refuse to touch them. So it fell upon Mr. Frohock to bury the victims. One corpse he was conveying on a sled to the cemetery, when the jolting of the sled caused the head of the dead man to slip to one side. The Eskimo who was helping to push the sled, upon seeing this, screamed with fright and ran away, leaving the schoolmaster to conduct the burial alone. The death-roll increased rapidly, but the ground was too hard and frostbound to make it possible to dig further graves; they therefore interred the remains of some ten or fourteen in the snow. After a time Mr. Frohock inspected the improvised cemetery, and found that the dogs had dug into the snowgrave and consumed the heap of dead Eskimos-only some bones remained. I sat there quiet, listening to horrors sufficient almost to whiten one's hair, and still Mr. Frohock continued to relate the circumstances simply, unemotionally, taking no credit to himself or his wife. One would imagine from his narrative that it was " all in the day's work." In Bristol Bay district, not so very far away, as distances go in Alaska, 800 natives died of influenza, more than half of the community, and some of the finest basket-makers in the country-women who weave and plait under the water the threads of the willows, making them as soft and fine as silk, and who fashion the baskets which are renowned all over these lands and on the Pacific coast as well.

Mr. Frohock told us that one difficulty was to induce the Eskimos to even open a tin of food for themselves, because they greatly fear any instrument which has a sharp edge. They affirm that anything sharp brings evil spirits who will cut the thread of their lives. They absolutely refused to handle an $a x e$ to chop wood for their fires, and many were found frozen stiff in their igloos. It was indeed a strenuous, hard, and sad time for this lone white man and woman, who had their own sick children to tend. That was the longest 
winter and the hardest she had ever gone through, averred Mrs. Frohock. She wondered why she was not ill herself, but, she added, "My husband and I simply could not be ill ; we had to keep on." They agreed that, as a rule, the Eskimas at Fort Hamilton are easy to deal with, like children, with strong likes and dislikes. They never punish their children, no matter how badly they behave. One day, said Mrs. Frohock, she whipped one of her little boys for some misdemeanour, and an Eskimo woman who saw her mete out the punishment was very angry with her. This woman rocked herself to and fro, weeping, and, pointing to her heart, exclaimed: "It hurt me. Stop! Too much whip!" Mr. Frohock overheard a native discuss him thus: "He all right to teach kids, no good as doctor." The Government supply simple medicines, and the Eskimos will come to the school and, whether ill or not, will ask for cod-liver oil, which they love. They will make all kinds of excuses to secure castor oil, pain-killer, and quinine. The natives live by trapping and fishing. Dried salmon is their winter food, together with moose and reindeer flesh, and there is great rejoicing when there is a wild-goose drive. These birds feed upon wild celery and other roots of the marshes, get very fat, and are excellent eating. As illustrating the enormous profits made by the furriers, an Eskimo trapper will bring his furs to the store to exchange for eatables and his few other needs. For a beautiful large white fox the native will receive only 20 dollars (£4), for red fox $£ 3$, and 1 dollar for a mink skin. Mr. Frohock showed us his parka, a fine one lined with mink, the outside of khaki and, as is the custom, the hood fashioned of long-haired wolverine, which stood out around his face like a wreath of feathers.

The Eskimo women wear a cotton garment loose over their squirrel parkas, in order to keep the fur clean. They never doff their parkas even during the summer. Some curious names were mentioned while I listened to the local gossip of this out-of-the-way post, names that appeared familiar cognomens to Father Sifton. "Hobo" certainly must be a peculiar character. Mike was a bad man, because he brewed 
sourdough hootch, a composition of brown sugar, fermented with hops, or rye, which made them all sing right joyously. A lady known as "Leaf Tobacco" figured prominently in their conversation. In the general diagnosis of their characters I gleaned that they were kindly, simple, more good than evil, and most of them had a strong leaning to the Catholic faith. The native inclination is to be moral; their marriages take place when they are from sixteen to eighteen, and are usually arranged by their families, or they can choose the one they like the best. They intermarry with their own blood too frequently, but there are no others to whom they can ally themselves. There is practically no marriage ceremony. The girl and boy declare their intention of marrying ; then they wander off together to a fishing camp or wherever they choose. I asked if this mode proved satisfactory, and was told "Yes." They live happily together, their chief desire to obtain enough food and have many children. When a child is born there is no need for a doctor-Nature, and what they are told by their own mothers as to the care of the child, is all-sufficient. Should there be any difficulty, and they quarrel and are no longer contented, they simply separate, the mother claiming the children and the man roaming afar. Such is marriage, arranged and consummated in this land of the Eskimo, where certainly a precarious living would be vouchsafed to solicitors whose chief line is divorce. Nor would clergymen and doctors enjoy the opportunity of becoming wealthy. I was shown the schoolroom where about twenty-five natives receive their education through the generosity of Uncle Sam. Their school term is in the winter-time, from $9 \mathrm{a} . \mathrm{m}$. to $3 \mathrm{p} . \mathrm{m}$. It must be acknowledged that as rich Uncle Sam pays the schoolmaster and his wifewith two boys to keep-110 dollars a month, and this in a frozen zone where the bare necessities of life are fabulously dear, there is precious little likelihood of this self-sacrificing schoolmaster becoming an extensive holder of United States Government Bonds!

The boat slowly edges away; the entire population wave a farewell. Poor, lonely Mrs. Frohock! I wonder wh $\eta$ she will again have a chat with another white woman? 


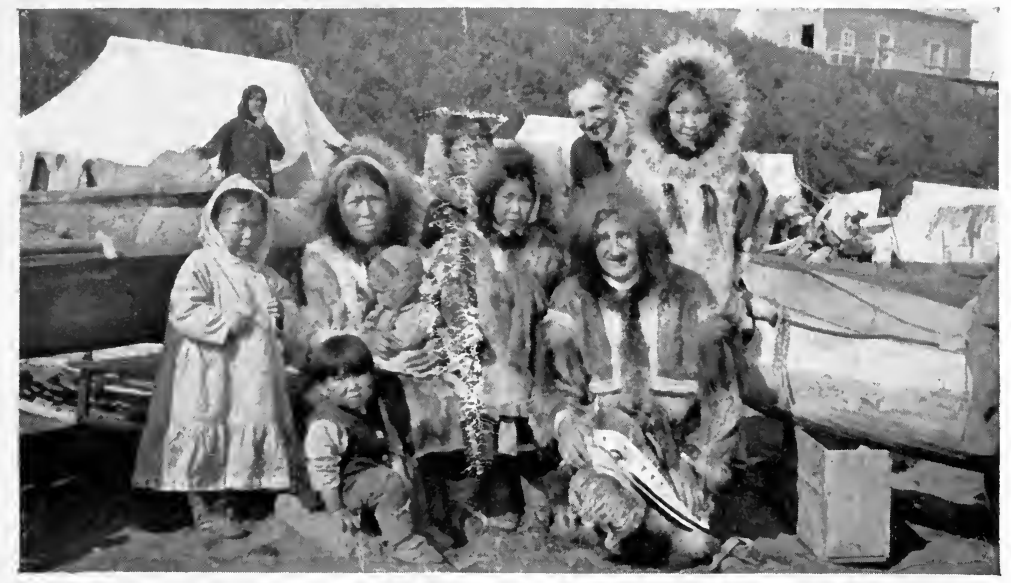

ESKIMO LIFE AT ST. MICHAEL, LOWER YUKON.

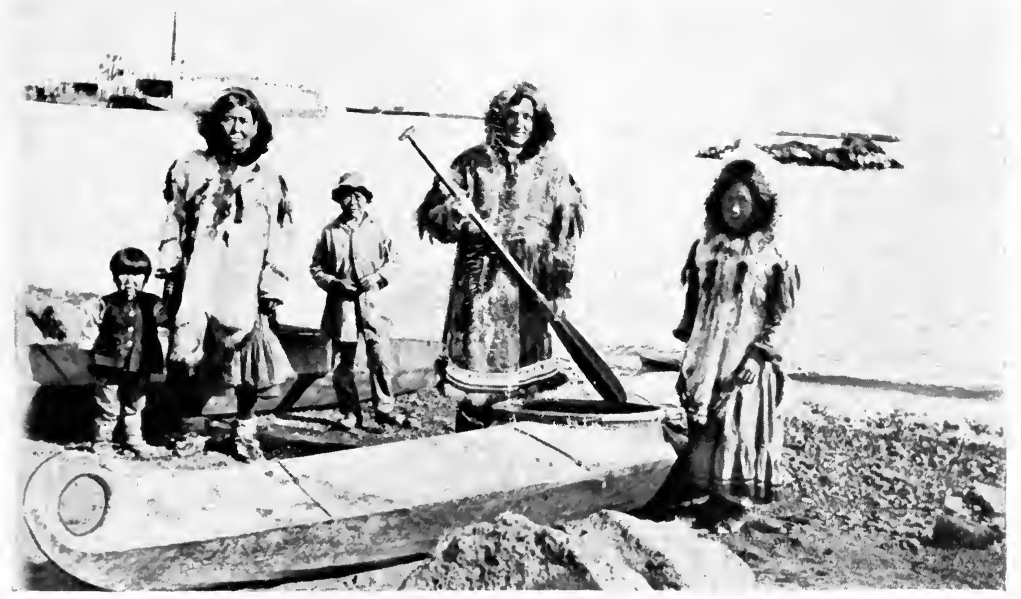

ESKIMOS AND KIAK BOAT. 



\section{CHAPTER XVII}

\section{ST. MICHAEL}

THE flat-bottomed Seatle No. 3 flopped around as if sea-sick when the waves of Norton Sound pushed her about like an ungainly duck. She seemed entirely out of place in the sea, for she was a river boat pure and simple.

We arrived at St. Michael early in the morning. From the sea the little town looks quite imposing, with its red roofs and large warehouses of corrugated iron. The Seattle No. 3 comes alongside the wharf, as it only draws a few feet of water, but the ocean steamers are obliged to anchor some 2 miles outside, discharging cargo and passengers upon barges. It is a grey day, although it is summer. They tell me that most of the days are grey, and so are the lives of the handful of people obliged to live here.

Again the same cry, "Oh, you should have come in the winter!" My soul whispers, "Heaven forbid!" Then they get enthusiastic about their dog-teams and races. Here is rather a large hotel-that is, large for Alaska, built in grey framework. It is steam-heated, and some of the rooms have bow-windows and are quite comfortable. The hotel is owned, and run, by the Northern Commercial Co., which company controls everything, practically speaking, in this country. They, with the American Yukon Navigation Co., trade with the natives, taking their furs in exchange for groceries.

St. Michael was founded by the Russians, and is situated on an island about 60 miles from the mouth of the Yukon River. It was founded in 1883 by Michael Tebenkoff, an officer of the Russian American Fur Co., and its original name was Michaeloffsky Redoubt. There are yet many relics of the Russian occupation; you remark it especially in the 
faces of the natives, Russian and Eskimo being singularly blended, producing a queer, ugly type. One Eskimo word I am becoming familiar with is " peluk," which means " not any." The native says " peluk money," "peluk moccasins," "peluk salmon," and so on, in monotonous iteration. There is nothing to do or anything to see to interest a traveller. There is one board-walk through the tundra, which leads you along the front and to the wireless station, and this is the only promenade; you soon become very tired of the monotony of it.

It is difficult to get away from St. Michael, and even in summer you may have to wait a month or six weeks for a steamer. From Seattle the ships go to Nome, which is a big town, where they discharge passengers and cargo. Then they look in at St. Michael, pick up mail and passengers, and sail back to Nome again, a distance of some 120 miles. After transacting business there, the steamers then sail direct to Seattle. With the opening of the Seward-Nenana-Fairbanks Railway, St. Michael will be more cut off than ever, as there are no exports, and the few people necessarily migrate elsewhere. The schedules of these steamers are liable to change, and that places the traveller in a precarious position. St. Michael at present has a general atmosphere of dilapidation. From its high, tundra-covered banks you have a fine view of the Bering Sea, and the grey gulls, as if matching the dominant grey, circle about one in a threatening manner, as if hungry, then fly screaming away to sea. It is a lonely place.

Most of the buildings, which at one time bulged in the busy gold days with merchandise and humanity, are now closed and boarded up, this naturally adding to the desolation of the place. The few remaining houses along the front that show any signs of life are occupied by half-breeds.

You pass, on the one and only walk, a U.S. Government school where a few children of the natives assemble in winter. Then is disclosed the Catholic church, which is clean and well kept, maintaining its good work in connection with the mission at Holy Cross. 
There is no Protestant church at present, owing to lack of funds; therefore the few people who reside here rely upon the priests, and these good men will travel on dog-teams in winter, miles away, to visit the sick and the dying. The U.S. Marshal has authority to perform a marriage ceremony, in addition to other official duties, but when the last boat leaves St. Michael in September most of the people will be found on board. There is an Army post consisting of some fifty men; barracks and other buildings are painted a vivid yellow with red roofs, as at Fort Gibbon. The Army represents the social element, and imparts the only air of liveliness the place can show. Last winter some eight white women preferred to remain " in," as they call it, and, with the Army and civilians, sixty-five people wintered here. Another eyesore on this board-walk is the site upon which the Steamboat Hotel once stood. Queerly enough, although the hotel has long since been destroyed by fire, the rickety old post and its sign still point the way. Since the hotel was burned down no one has bothered to remove the twisted, rusty corrugated iron with which the building was constructed. They have pushed some of the warped remains down the bank, and there they will lie for ever.

Much has been written of the old Russian or Eskimo blockhouse, of which one sees postcards all along the Yukon. Now, as I sit before it, on a broken seat facing the sea, I wonder about its history. It is a small octagonal wooden structure, with pointed roof and a tall flag-pole. There are four tiny square look-out windows through which obsolete cannon overlook the sea. The position was certainly well chosen, because no vessel of any description could have entered the bay without being observed. Whether this was built by Russian or by Eskimo hands no one appears to be certain. It is rather a pity théy do not repair it, if only by reason of its historic interest. Its condition is such that before long a gale will whisk this landmark into the sea it has watched over so long. All is barren; not a tree can be seen : simply rock and tundra. A lot of driftwood is piled on the beach, this having floated down the Yukon and drifted here- 
most useful, as fuel is very expensive. In walking to the hotel for lunch, some dogs obstruct my path, disputing my right to the narrow walk. I tell them to " mush" - they understand and make room; " mush," to their intelligence, means "go !" In the hotel I have a large comfortable room, the cost of which, 2 dollars a day, was not excessive. The meals were substantial, and in such a place, where nothing is grown locally, I considered myself lucky at finding the food so good: Naturally, when a cook caters for thirty to fifty rough workers, quantity takes first place; daintiness of service can hardly be expected. It was a sight to observe the people at table; sure no moving-picture show could have competed with the types presented. Bret Harte would have known them all, and if some were lacking in cleanliness, they made up for it lavishly in picturesqueness. The prices for the meals were : Breakfast, 75 cents; lunch, 1.25 dollars; dinner, 1.50 dollars-the humanity show was free. There they satminers, squaw-men, gamblers, prospectors, adventurers, and plain, honest men. It occurred to me what an interesting book of stories might be written if each man would truthfully narrate his experiences. It was quite amusing, as a novelty, to watch the men and share their meal, but when it goes on for days at a time the novelty is apt to wear rather thin.

The next morning, fortunately, I was invited out to lunch by one of the resident ladies whose husband is a manager of the N.C.C. She had a pleasant home, which she runs without servants, and regaled me with my first reindeer steak, which was excellent in flavour and tender. The two companies, the Northern Commercial Co. and the American Yukon Navigation Co., treat their employees very well. A man will have his house and all furnishings found for him, including linen, piano, silver plate-enough to use in an ordinary way - and firing, the latter a very great consideration. My hostess had her dog-stable, and after luncheon she took me to see her team. They knew their names perfectly, and she gave each dog a hard dried salmon in honour of my visit. I have come to the conclusion that feasting does not add to attractiveness-what with sharing meals with mix- 
tures of men, and watching the huskies crunch and devour evil-smelling fish, certainly eating is a function which should be performed in solitude.

At St. Michael a thing which particularly astonishes one is the gigantic waste of capital, represented by hundreds of large, fine river steamboats tied up the entire length of one muddy bank. These boats, in the days of the gold stampedes at Klondike, Fairbanks, and Nome, formerly carried as many as 600 first-class passengers, and have transported millions of dollars' worth of gold nuggets and dust. Now they lie, some pitched on their side, others stacked in all positions and angles, three and four deep, simply rotting away. The steamers have cost fortunes, but in these days Alaskan trade does not justify the numerous boats being put into service. Overhauling and painting would cost enormous sums. These boats had once been white, but would now require thousands of pounds of paint to make them resume even a passable appearance. Another instance of neglected steamers is to be found on the other side of the island, where you can see what they call " Steamboat City," a mighty and dismal array of boats tied up rotting. Nothing speaks more plainly of the general decline of traffic, trade, and passengers than do these tragic lanes of decaying steamers. I was astounded at what appeared a wanton waste of capital, but was told that these steamboats had paid for themselves many times over in those days when gold ruled the land. There is much satisfaction at St. Michael, and a great deal of grumbling at Nome, so report says, because the Fort Davis Division at Nome is to be transferred here. Personally one cannot help feeling sorry for soldiers stationed at these lonely, lifeless places. Still, conditions are much improved since the coming of the wireless, with its frequent news of the "outside." One evening I was invited to the fort, and in the big recreation hall, which is similar to others presented to the Alaskan posts by that Samaritan of the U.S. Army, Helen Gould, we witnessed the moving-picture show. Here were gathered the Army, civilians, Eskimos, and half-breeds. It was a source of annoyance to the white people that the 
Eskimos permitted their children to run all over the hall, falling down, crying, and creating such a din that it was difficult to keep one's mind on the moving plot.

Eskimos never correct or punish their children, for they believe in reincarnation and consider that every child represents the spirit of one of their ancestors. Therefore, it would never do to beat the spirit of your grandmother, let us say, even though embodied in your own child! One of my experiences here almost placed my projected visit to Nome out of the range of possibility. It happened in this way: People here are kind-hearted, and want a stranger to see all that can be seen. It was arranged that two ladies and myself-one of the ladies accompanied by her little girl, a baby of two and a half years old-should go in a tiny gasolene launch across the wide bay to visit an Eskimo village 3 miles up the coast. When I beheld the launch, which looked very sinkable, and the young half-breed in charge, I had " ma doots," as the Scotch have it. However, as my dangers in travel had been by no means few, I decided to trust to luck. On we went, the engine every once in a while refusing to work. Then the boy would tinker with something, and on we would go again, the engine puffing and threatening to blow up. By this time we were miles away from any help, in the midst of cold glacial waters, with rushing currents in which even an expert swimmer could not last long. One of the ladies scrambled to the engine and pretended she understood its mechanism. I looked down at the sweet-faced, blue-eyed baby, unmindful of danger, then at her mother, whose face had turned ghastly white. If going to one's fate in the cold waters of the Arctic was to be, I didn't relish it, but for the baby's sake it seemed dreadful. There was a horrid scraping on the bottom of the launch; we were on the rocks and held fast. We pushed, shoved, they turned this and that lever, and still we stuck, the waves washing us higher up on these jagged rocks, with a very good chance of ripping the bottom of the launch. Then all at once a fog settled down upon us - grey sea, grey sky, and grey mist. The energetic lady who claimed to understand the engine did something to it; a big 


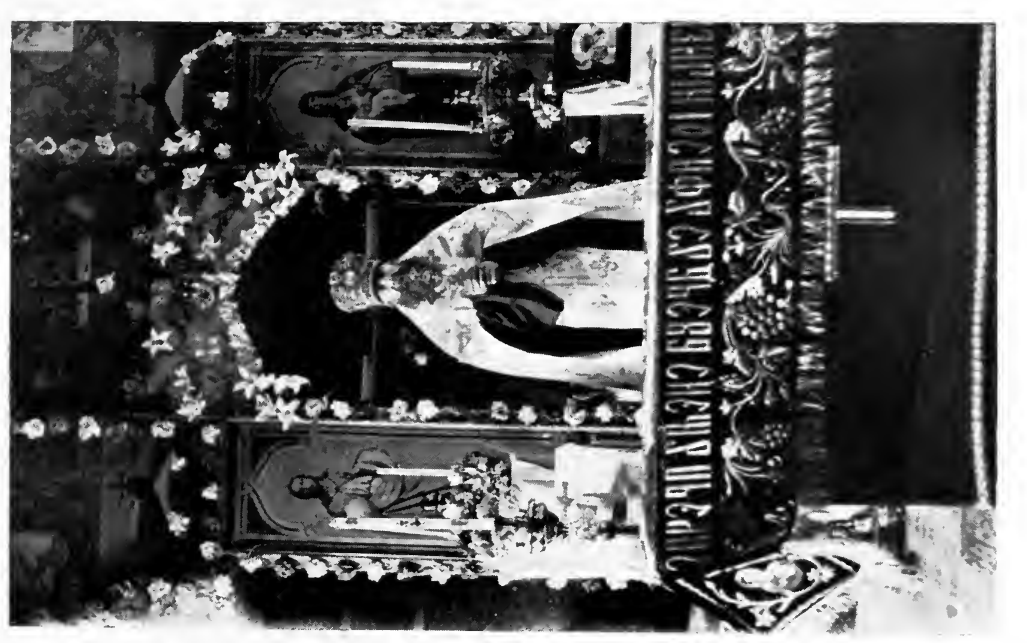

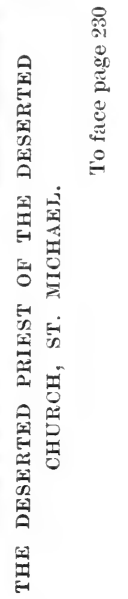

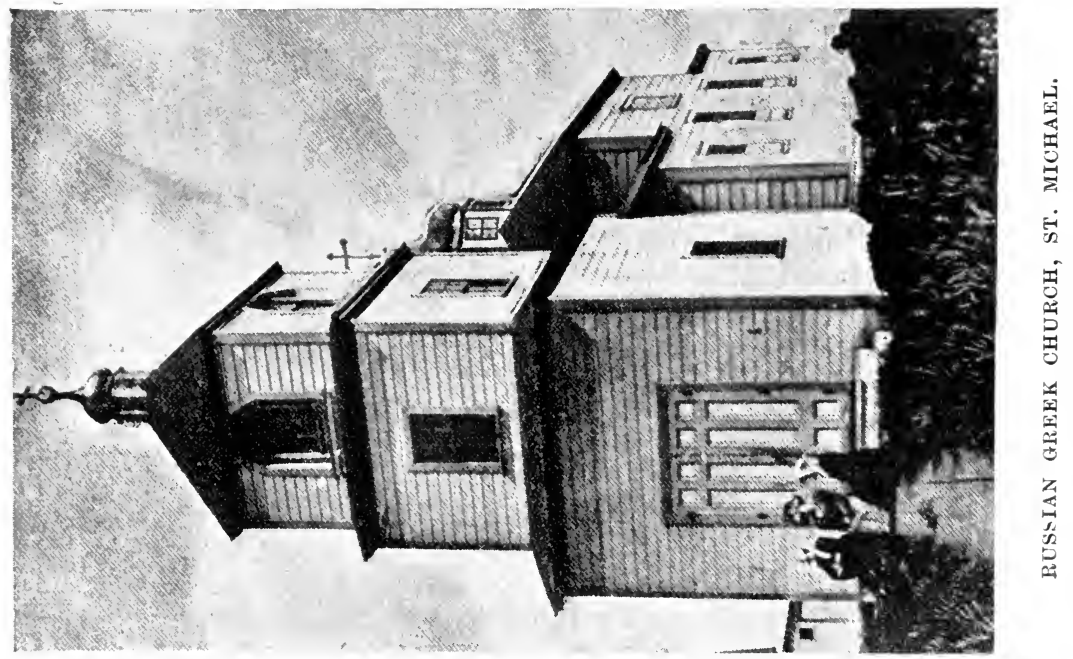



wave threatened to swamp us, but had done us a good turn in the end, because it had washed us clear of the rocks. Now the question was, Would she leak? Had the bottom been damaged? It appeared not; the engine throbbed, and we beat our way back across that bay, fear in our hearts; and it was with thanksgiving I stepped ashore, holding the precious baby for its mother. I don't think I even thanked the energetic lady for her outing!

The most imposing edifice at St. Michael is the Russian Greek church, which was built some fifty years ago. In those days it must have been very pretentious, with its grey wooden walls, green belfry, and domes, as is the custom in Russia, with the difference that in Holy Russia the domes would be coated with gold plate of the thickness of our threepenny bits; but in this deserted town there is no gold on the domes, nor apparently in the coffers of this pathetic church. Through the introduction of friends, we visited the venerable priest in his small house, adjoining the church. Afterwards he took us over the church. $\mathrm{He}$ is getting quite old, lives alone in his almost empty house, and exists in the most frugal manner. Indeed, at times he would have starved to death had not the people looked after him. Speaking very seldom, and in broken English, he explained as well as he could that he had not received one penny of his salary since the Bolsheviks had ruled over Russia. It certainly was sad to be with this fine, venerable character, who had given his life to his Church, and who lives in the memories of the dead past. Old, forgotten, and forsaken, sometimes he holds a little service, but nobody comes. He appeared delighted to see us, but no one could understand much of his conversation, although we all tried very hard. I spoke French, but that meant little to him. Then I tried the half-dozen Russian words that I had picked up at Petrograd, but these produced a faint smile, probably evoked by my bad accent! However, he was childlike in his pleasure at seeing us, and showing us all his treasures. Evidently he had come from a noble family, for here were his coat of arms and college diplomas. Searching in an old trunk, he brought to light 
photos dear to him, but faded beyond recognition, also some really lovely jewelled crosses in silver and gold. Then we entered the church with him, and he donned his gorgeous vestments, heavy with jewels, relics of the past. It seemed to afford him great happiness, as he seldom has an opportunity of showing these wonderful things. His face beamed as he endeavoured to make us understand. I felt more than sorry for him. It was pathetic, just like talking to a man who was buried alive, although himself unaware of the fact. My prayer is that at least some of his Russian relatives have been spared by the Revolution, and that some one of his own kin will come for him. Carefully unfolding paper after paper wrapping, he produced at length a wonderful piece of embroidery, heavy and rich with gold and silver bullion thread, representing the arising of Christ from the tomb. This was only used at Easter service, when he wore his white and silver robes. Then he placed on his head a gold or gilt mitre thickly set with coloured stones and pearls, and in his hands was a sort of sceptre. Poor, faithful priest, he might even lose his life one day for the valuable church paraphernalia he possesses, yet he is at times on the verge of starvation. He is very proud, and it is almost impossible to induce him to accept help in any form. Last winter one of the citizens found this holy man without coal or wood. There were no fires either in his house or in the church, and the temperature was approaching 50 below zero! He would have frozen to death in that terrible climate had he not been rescued. At another time he went to the general store to purchase a little fat to cook his food in. He handed out some small change, inquiring if it was enough. The salesman lied splendidly and replied that it was, making up the deficiency from his own pocket.

Again, at Christmas, the Northern Commercial Co.'s representatives sent the priest a box of good things, amongst them apples and oranges, but he said: "The children must have these ; I can go without." Here is a splendid chance for a real philanthropist. As we passed out, we surreptitiously slipped dollars into the charity box. When he dons 
his heavenly crown with its jewelled rewards of patience, devotion to duty, of a life spent in the care of a few halfbreeds at isolated St. Michael, then peace will be his.

Another day I spent in calling upon Eskimos, accompanied by a lady who knew several of the native families. The odour of the igloos was practically unbearable, and although I was very curious to see how they lived I could not linger long, and was obliged in sheer defence to seek the outer air. Everything reeks with oil, fish, and skins. I went into the home of Pete, and my friend, in introducing this swarthy Eskimo fisherman, remarked that Pete had the cleanest house, and was the best housekeeper she knew. I listened, looked at her stupidly, wondering if she were blind, or prevaricating, or simply bereft of reason. Pete grinned his approval of her encomium. The smell of rotting fish became too pungent, and after a glance at a tiny window, a filthy bunk, a broken table, many pairs of mukluks, and snow-shoes hanging on the wall, I bowed to Pete and absconded without ceremony into purer air. It was the same in all these igloos. Some were simply mud-holes; there was always the odour of drying or rotting fish, seal and walrus oil, mud floors, sometimes with walrus-skin mats scattered about, dirty rags, and many children. Eskimos love children, and welcome as many as fate sends them. Some of the babies and elder children were very pretty, with bright eyes, very red cheeks, and long, straight black hair. The maidens develop early, and in many cases are extremely good-looking, but at about twenty-five they begin to age, their beauty has flown, and wrinkles come to stay. All the Eskimos were wearing their fur parkas, although the month was August, and they had calico slips over them.

Some of the malamute dogs have very fine heads, the cross with the wolf being apparent. They form a perfectly natural background sitting in their holes around the igloos, and attracting one's attention by an occasional howl. Next I was taken to a sort of bath-house and dance-hall combined, where they hold their " kjems," or dances. One is obliged to bend as low as possible, and pass underground through a 
hole in the hard mud. Then, having accomplished this, you emerge into a sort of pit, where a fire roars. Above you is a platform of earth, say $2 \frac{1}{2}$ feet wide, and above that are placed boards for you to sit upon. There is an open hole in the earth roof through which a glimpse of sky can be seen, but its real purpose is that of a chimney. In winter the Eskimos build a roaring fire, get very warm, perspiring freely, then they run out and roll naked in the snow. This is regarded as a bath, and often ends in pneumonia. When they decide on a kjem, they enter the hole and build the fire in the same fashion, and beat upon large round drums consisting of a single skin stretched across a hoop and securely fastened. In this they largely resemble, whilst they chant, the Arabs and Moors with their tom-tom music. Then the dancers come upon the narrow platform and begin swaying their bodies. They scarcely move their feet in Eskimo dances. The gestures are mostly done whilst they sit, but they move their hands and bodies in time with the music. The dances continue for a long time, and as they become more jubilantly excited and the warmth and exertions increase, they begin removing their garments, until finally they are quite nude. Eskimos think nothing of that-they are, as a race, by no means modest. I am told that farther north, where life is even more primitive than here, when going into the snow-block igloos you will find the occupants naked and unashamed. It is very difficult for white people to see a $\mathrm{kjem}$, as the native is superstitious and not given to performing in public. Also, they are secretive about their births and deaths, concealing their movements from other than their immediate relatives. One of their hobbies is a desire to adopt children, and especially if there happens to be white blood in the infant. Sometimes if a girl is about to give birth to a child and there is no father, all the village will naturally know about it, and a family will patiently await the little one's appearance, then adopt the new-comer. Many a time an Eskimo girl will be driven out of the igloo to face her maternal ordeal in the snow. She will think no ill of her people for such treatment, but will hide away in some rocky cave, or even dig herself a shelter in a 
snow-bank, like an animal. Here she will bring forth her offspring, taking entire care of herself, then walk back to the igloo, her baby snug and cosy in the hood of her parka! When she comes into the home circle again, they will one and all welcome her, and be glad to see the little one. Verily the world is a hotch-potch of queer peoples and customs! It is amusing the way certain people regard the Eskimo in comparison with the Indian. For instance, a big husky man who has been in Alaska many years, an old stampeder, called upon me. Everyone, by the way, visits you in the wilds. I can assure my readers I have had some of the most peculiar callers imaginable. This man said he heard I was writing up the country, and volunteered to tell me some of the history of the early days. As we talked, he mentioned that his native wife and child had died last winter during the terrible epidemic of influenza which swept the country. I, being a cheechako, exclaimed: "Oh, you are a squaw-man!" $\mathrm{He}$ looked up quickly as if to read my thoughts, then angrily replied : "No, I am not a squaw-man; there is a great differ. ence. The Eskimo woman is of a much higher class than the Indian squaw." I agreed with him; it seemed the easiest way out of it. Afterwards I heard that this same man had married another Eskimo widow who was rich-she owned hundreds of reindeer. There is fortune-hunting even in Alaska!

As there was no steamer due for Nome for another two weeks, and as I was heartily tired of St. Michael and its board-walk, I determined that no matter how primitive the Arctic proved to be, I would embark on it for Nome. The Arctic is a small gasolene schooner of something like 70 tons, owned by the captain, who has a contract with the Government to carry the mails to the mining camps of Golovin and Bluff, also to Nome.

\section{The Schooner "ARCtic."}

All through these miles of travel, beginning with Governor and Mrs. Riggs at Juneau, with Mr. and Mrs. Davis at Fairbanks, and sever 1 of the sourdoughs en route, I heard vague allusions to this loat, the Arctic. 
The very name seemed to conjure up before their eyes a picture of dismay and horror. Mrs. Riggs shrugged her shoulders and looked wise, the Governor shook with laughter, Mrs. Davis related her extraordinary experience, and Mr. Davis affirmed that he "nearly died" on the Arctic. To even mention this boat was like uttering some fraternal word, as if it gave you the entrée to a secret society. They warningly prophesied : "You may have to take the Arctic. Wait and see, then you'll know.",

Sure enough, the Arctic was to be my fate, either that or remaining an indefinite period at St. Michael, where there was nothing to do but promenade the rickety board-walk between the banks of tundra, and await the Seattle steamer. This would shorten my time at Nome. I decided to risk the Arctic, being very tired of the hotel and watching the men at meal-time. In the afternoon at 2 p.m. the Arctic was due to depart for Golovin, Bluff, and Nome. Fourteen men and myself mustered at the dock, and some friends appeared to see us off. The captain, engineer, and cook run the boat single-handed. What an existence! and how hard they work, risking their lives every time they cross Norton Sound and Bering Sea. I stood on the dock, and looked down upon this 70-ton schooner. It was anything but inviting; certainly there was a neglected, suffering look about it, dirty outside, and obviously no cleaner inside. Everyone cracked jokes and prophesied we should have a rough time. The sea looked grey and ominously choppy. A great bustle ensued getting our luggage and mail on board; quite a few of the men voyagers had also been fellow-passengers on Seattle No. 3. At last the order came to go on board. Now, so far as the Arctic is concerned, you don't proceed down a gangway in orthodox fashion. When the boat bobs your way, they simply say " Jump!" several hands outstretched to grab you. I jumped-it is some feet below-and, happy to relate, I arrived. The deck is covered with ship's belongings. Very tiny; there are no chairs, but someone found me a bucket, and I sat on that. The men stood or sat on the deck in close proximity. The deck was too dirty to put my fur rug on, 
and what with the oil, filth, and the smell of gasolene, the men had cause to grumble. I crouched against the railings, enthroned on my upturned bucket. We started. Men talked continuously, I kept silent; and as you cannot help listening whilst huddled together, it struck me that their conversation was extremely stupid. The sea began to get unruly; here were billows indeed! There was a small space below deck, and you negotiated a ladder to reach this prehistoric saloon. Now, I am a good sailor, it is born in me, for my ancestors came of that hardy race who " go down to the sea in ships." I had, thanks to my war work, become used to crowds of men, consequently was not the slightest bit nonplussed at being the only woman amongst them. I also know the unselfishness of men en masse, and their chivalry where a woman is concerned. I fully realized we were in for an uncomfortable twenty-four hours at least. I foresaw that the men would be ill and weary. For myself, I could hold out, as I am never sea-sick. Therefore I made them a little speech. "Boys," I said, "that place below where the bunks are I have no intention of entering. You take it for yourselves. I shall sit here, as I infinitely prefer the fresh air." I knew instinctively they would have given me the place alone, and that all would have remained on deck. But my reasoning was this : Why should fourteen men have no rest or shelter just because one woman's comfort was at stake?-if, by a stretch of imagination, you could allude to it as comfort. Fourteen to one! The odds were too selfish!

Time passed ever so slowly, waves splashed over the forecastle, the boat dived and rolled. First one man was overcome with mal de mer, then another, and the epidemic spread ominously. I turned my back to them. It was not pleasant.

The men were grateful that they could lie in those bunks; hours seemed days as we pitched through that sea, dark and grey. The captain came along and kindly asked me to take shelter in the pilot-house, but I said I was quite all right. That pilot-house was no bigger than a sentry-box; I had inspected it before. There was just enough room for the steering-wheel and two bunks, one on top of the other. To 
my mind came recollections of what everyone had said of the Arctic; they had not exaggerated it one whit. Half the time the prow was awash. How she tobogganed on those north sea rollers! It began to be cold. The men would recover and come to speak to me, but conversation lagged tremendously. There was no standing up on the Arctic-everyone crawled. By-and-by the captain came round and announced that dinner was ready. I must come, he insisted. A meal had never occurred to me. I had some chocolate and biscuits, and thought these would suffice. The captain took hold of me, and we climbed over such things as ships' impedimenta, reaching a hole whence issued odours of food. Carefully, with the lurching of the ship, we held on fast, went down a ladder into a retreat about 6 feet, cubic measure. Here, at a narrow table, we sat just as close as dates in a box. Then the meal began. The cook was a wonder. How he fried salmon, boiled potatoes, and even evolved a pie, in so limited a space was a feat of legerdemain that puzzled and pleased me. A small lamp afforded us light. The food was put into agate enamelled pans, and we fished in, helping ourselves. The salmon was not cooked badly, and we had cold reindeer meat as well. I certainly have dined in some strange places, and I have had many a worse meal than this, although the schooner was playing a continuous game of leap-frog: After dining I crawled back to my bucket-seat. Hour after hour passed; I curled myself up as small as possible, a little after the fashion of the malamute dogs. It was very dark and so cold ; most of the men had gone to the bunks. Time crawled on to midnight ; the wind howled; the waves dashed all over the front part of the boat. I laid my head on a coil of rope, trying to sleep. The captain came and told me I must now go into the pilot-house. By this time the cold had so numbed me I could resist no longer. In the pilot-house the engineer was at the wheel, and I sat beside him under cover on a high stool which rocked and rocked so that it was impossible to keep on it. I had no choice but to go into the lower bunk, so in I got, hat, coat, boots, and all. The bedding was horrid, but it meant safety, better than getting washed overboard. 
I was thankful for shelter. I had on a wide-brimmed black velour hat, bought at Mercie McHardy's famous shop in London. This I pulled all around my head and face so as not to touch the pillows-and there I lay. Somewhere about 2 a.m. our schooner got on the shoals; it was quite dangerous for a time. In the darkness of that cubby-hole came occasional dim lantern flashes, and through my házy dreams I heard, as in a distance far away, like a song, " Shoal, $2 \frac{1}{2}$ feet, 3 feet, 4_-" and two brown, fantastic figures moved about mysteriously. With the dawn I arose, and resumed my seat on my reserved bucket. Tired? Yes! Then we passed Golovin, where the mail had to be taken off. Now we pass Bluff, another mining camp, where a huge black boulder of coal shows up against the leaden-grey sky. Gold and coal are found together at this place. The captain descended into the small boat and rowed ashore, a distance of over a mile, with the mail. How these three men carry on, as well as they do, the work of the Arctic is extraordinary. It seems to me they make a living in the most difficult way, and always at great risk to life. They have no time for scrubbing the boat. It would not make much difference if they did, with water coming over most of the time. The men begin to emerge from their dug-out. One does not feel very presentable or care to talk after having been tossed about all night, half frozen. Now, in the morning, there is not a drop of water to refresh one, or any place where you can tidy your hair. Fortunately, I had a black chiffon motor veil, which was long and wide, covering up at least some defects. It was a clever sister who introduced veils; every woman has cause to bless her for the innovation.

Everything passes if you wait long enough-even a night on the Arctic. 


\section{CHAPTER XVIII}

\section{NOME}

From the tiny, cramped deck of the Arctic after an unforgettable night, and upon emerging from the fog-bound Bering Sea, Nome, which had beckoned to me from childhoodNome, that stretched its length along the beach to the extent of a couple of miles, certainly seemed good to look upon. From its size and location this town promised at least some comfort, and I felt that after my experience on the gasolene schooner the luxury of a tub, and a space large enough to unpack and procure some clean garments, would indeed be a blessing. Sledge Island, so named by Captain Cook because of a sledge with ivory runners which was found when he landed, is a retreat for ships when a storm rages. Nome having no harbour, this barren, rocky island affords a certain amount of shelter. The Bering Sea curves inland at Nome and forms two projecting points-one Cape Nome and the other West Point. In the distance, a seeming barrier, the Sawtooth Mountains rear their jagged peaks. Along the water-front large warehouses, the tower of Eagle Hall, the Catholic church, and other buildings, give the impression of a town of importance. Nome is backed by great moors of tundra, that soft, spongy moss so difficult to mush through. This extends for some miles, then drifts into rolling hills, which, in their turn, are overshadowed by mountains; while yet farther back lies the Sawtooth Range, thus named because its sharp points resemble the teeth of a saw. The native name is Kighiaik, and the highest of this group, Mount Osborne, looms up in the heavens to the height of 4,700 feet. The general effect from the sea is pleasing, imparting to Nome a splendid background. Furthermore, the town is situated between two rivers emptying into the 


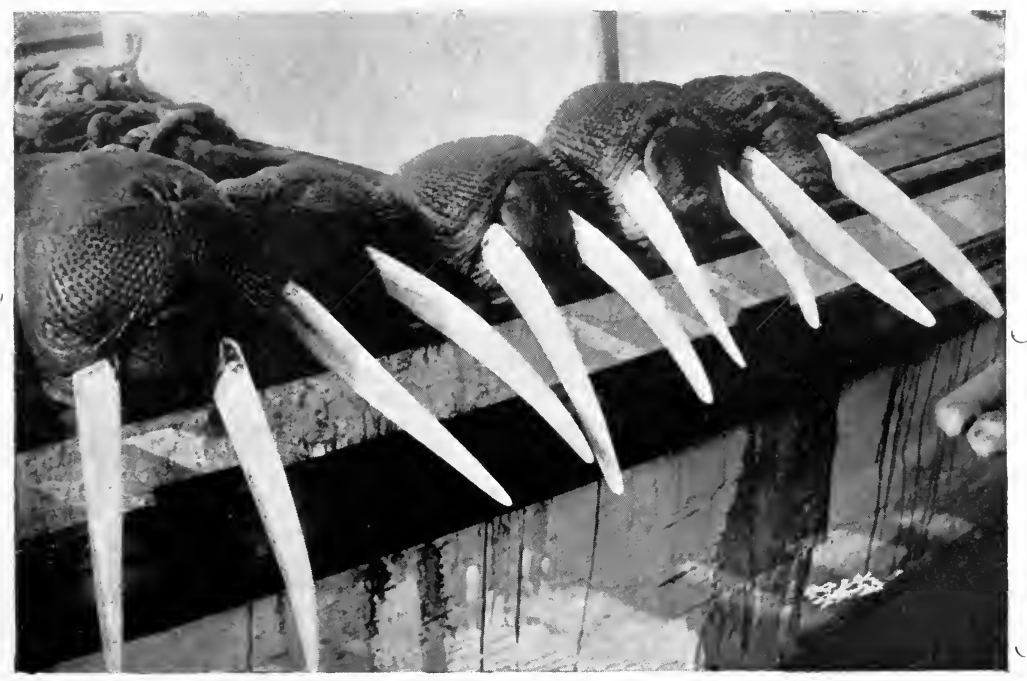

A LUCKY WALRUS DRIVE.

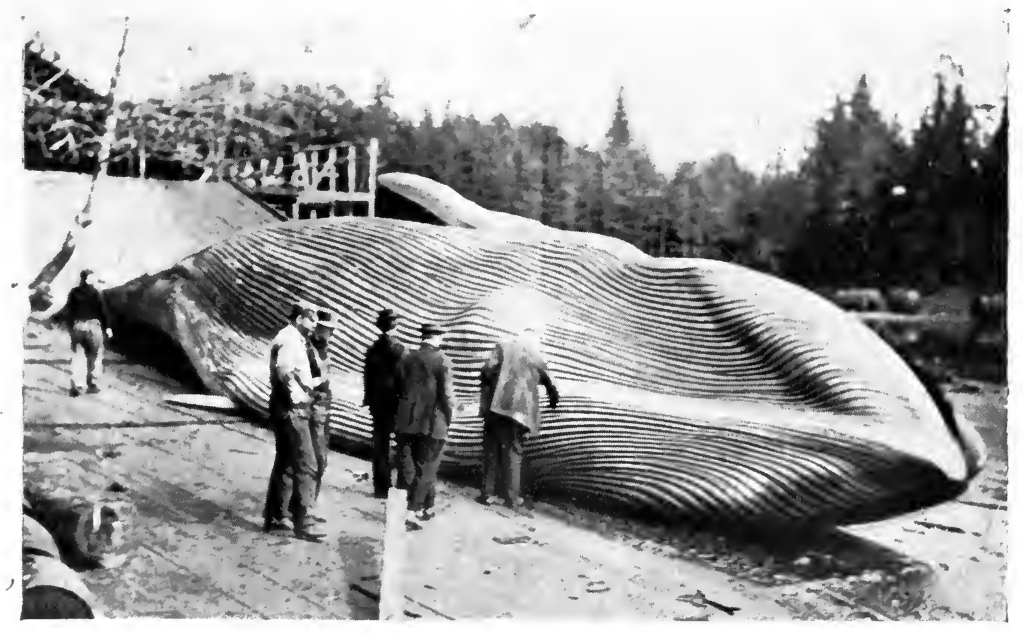

A WHALE AT REST. 

Bering Sea-the winding Snake and the Nome, In all this vast area, as far as the eye can glimpse, not a tree, and scarcely a bush, relieves the tundra-clad landscape of the chief city of the Seward Peninsula. Nome appeared to be so peculiar a name that I asked if it had any special significance. They informed me that it had been derived from the Eskimo phrase "Ki-no-me," meaning "I don't know" ; then it became shortened to Nome. This so-called "Queen City" of the Bering Sea does not permit ships to come within a couple of miles of her wharves. It has an open roadstead, but a jetty or harbour is in course of construction. Meantime ships are obliged to land passengers and merchandise by scows and tenders. Getting ashore is no easy matter, especially from the bobbing Arctic. A tug with an open scow comes out to us, and here I practise yet further feats in the jumping line. It would seem to be the height of unwisdom to travel in Alaska in one of the tight-fitting skirts so fashionable to-day. After flopping about on the scow amid giant breakers, I was put in a cage, or basket, and swung high up by cable, then finally deposited on the wooden wharf. Soon I found myself walking up the "Front Street," Nome's principal thoroughfare. To me there is an excitement, an intoxicating zest, in the task of exploring a new town. The streets are paved with wood, as are the sidewalks. In a few minutes the Golden Gate Hotel, just off the main street, was pointed out to me, and I entered, My first inquiry, after having been shown a large front-room, was, "Have you a bath-room?" to which Mr. Swartzell, the genial proprietor, replied, "Certainly; we have three." That reply was as music in my ears. Then he confided to me that he had not been "outside" for twenty years, and did not know how rusty his manners had become, he being hidden away in Alaska for so long a time. I assured him that he need have no qualms on that score, as the war had not changed the mannerisms of the world. It is said that "The rolling stone gathers no moss." I always reply: "But it gains polish." When I heard that he had come originally from Philadelphia, I felt sure he would find the 
Quaker city unspoilt, and that the war had scarcely touched it.

The price per day of my room was 2.50 dollars. There was nothing to grumble about; it was steam-heated and electrically lighted. The baths were clean, with a good supply of hot water.

In this country of glaciers, where, upon digging 2 feet below the surface, you find the ground frozen solid, you will notice the warped condition of the buildings and floors. Nothing is quite straight and level; there are cracks and crevices in the walls, whilst floors are billowy as a toboggan. Thus it was at the Golden Gate Hotel, a condition met with everywhere in the North of Alaska. Having indulged in the luxury of a clean outfit, I sallied forth to view the town. I find the custom of not serving meals in an hotel awkward, especially on a rainy morning, when it is a nuisance to have to dress and go several blocks for a cup of tea or coffee. In Alaska coffee should be invariably chosen, because the people are not hardened tea-drinkers. The tea usually served is the China green tea, or maybe Russian, although Lipton's tea can be obtained in most of the best grocery warehouses in the country. It is a convenience to keep by one a tin of " canned heat," and also a tin of ground Washington coffee, so as to be able to make your own coffee in an emergency. I nearly always travel with some apparatus whereby I can concoct a hot drink at short notice. Americans laugh at my English names. They say "canned" while we say "tinned"; lemon squash struck them as extremely funny. They call the same mixture lemonade; the only squash they know of is squash-pie.

I directed my footsteps past the well-built post office, the life-saving station, and to the restaurant kept by Mrs. Niebling, who is a real Alaskan sourdough, and an excellent cook, as I afterwards ascertained when I had become acquainted with the Nomeites, and attended several dinnerparties at which this experienced lady had carte blanche.. I was surprised to find that she could serve as good a five-course dinner as one could obtain anywhere. It is commendable 
when one understands the varying conditions of the market, which depends for its supplies upon the erratic arrival of the ships.

To my great delight, I found my travelling companions, Senator and Mrs. Heckman, seated at the first table. Naturally we were pleased to meet again, and they to hear the news of the Yukon and Fairbanks, which they are to include in their itinerary on their homeward trail to Ketchikan. I joined them, and as they had ordered reindeer steaks, I followed their example. This meat is 'firm, lean, and of a choice flavour, and served sizzling hot is a dish hard to beat. Much resembling moose, reindeer is better than caribou. In this immense frozen Northland Nature has provided ample big game wherewith to feed her people. In the future, I understand, reindeer meat will be exported in great and much-needed consignments to all parts of America and Europe. After our meal, the Senator and his wife, who were also staying at the Golden Gate Hotel, proceeded to show me around, they having already passed a month at Nome. Along Front Street was a double line of frame buildings, mostly shops, the owners resident on the top floors. Big warehouses displaying groceries, miners' outfits, and all the innumerable requirements of the pioneers, are met with at every turn. From a bakery issued odours both sweet and appetizing. Here were cakes, pies, and candies-welcome sights after, for instance, such places.as Tanana. Nome boasts of a " department store," called an emporium, rather diminutive as to size, but its stock of goods is well chosen and adapted to the needs of the country. Progress and prosperity go hand in hand at Nome, which also boasts of an efficient telephone and wireless service.

To me, passing through the streets, it was a unique experience to see so many Eskimos, men, women, and children, wearing their parkas. Some of these garments had really beautiful borders stitched in patchwork designs of various furs. The ladies affected numerous tassels or fur strips which hung from their shoulders and waists. The more strips, the more fashionable and important was the wearer. 
The parka of the woman was apron-shaped around the bottom; the men wore theirs straight and without quite so much embellishment. Legend offers a reason for the dangling strips of fur on the back of the parka. Evil spirits, or devils, slink along, it is said, in the snow and catch the unsuspecting Eskimo, but the strips would be pulled off by the Evil One and the Eskimo would make his escape.

The men were selling carved ivory billikins, cribbageboards, napkin-rings fashioned from the tusks of walrus, well-made specimens of their handiwork, in several items of which the map of Alaskan coasts was depicted in black. The Eskimos excel in ivory-carving. In this, as in the making of moccasins and mukluks, they have a special original style. The women smiled, paused and looked at me as I loitered in order the better to see them. The hoods of their wolverinebordered parkas, standing straight up, framed their broad faces, and the yellow fur contrasted oddly with their straight black hair. The blue tattoo marks on their chins-four straight lines from lip to chin-denoted that they were married, or had arrived at the age of matrimony; the redcheeked children, also in parkas, they led by the hand. I thought they were most fascinating; their dark eyes flashed, and they smiled apparently with the sheer joy of living. They are a harmless, pleasant, docile race, inclined to be slovenly, but with a picturesqueness entirely their own. One simply had to buy from these remarkably interesting denizens of the Arctic. There were several curio-shops en route which attracted me greatly, and where, later on, I spent much time and money. These Eskimo novelties are entirely local; in no other part of the world do you become so intimately acquainted with walrus hide, teeth, and tusks turned into every conceivable form. Seal-skins - the hair-seal, not the kind that our coats are made of-fashioned into trousers, vests, and overshoes, and mukluks, are seen everywhere. With a suit of hair-seal, I am told, one can even sleep upon the ice without fear of freezing. Sleeping-bags made of, and lined with, reindeer skin are used by most people in this part of the globe. Rain-coats made of the skin of whales' in- 
testines are in great demand-the Eskimo equivalent for a Burberry waterproof. The intestines having been cleaned and dried, the Eskimo woman sews them cleverly together into superimposed coats, which look something like oilskins, and never retain the wet. We now turn into the second main street, where we witness a funny incident. A lady was walking along the wooden sidewalk, when her heel became firmly wedged in a hole. When we passed, a man was endeavouring to release her, and in a few minutes she was free. But it afforded all of us a hearty laugh, and no one enjoyed the fun more than the lady herself. In this street the Catholic church, a large frame edifice with a tall green steeple, is situated. Farther on is the Holy Cross Mission, a largish place, another branch of the mission at Holy Cross, on the Yukon River. Formerly it served as a hospital for white people as well as for natives, and was under the direction of the French Sisters of Providence from Montreal. I am told that during the winter this hospital was turned into a refuge for the influenza victims, and that it was packed to its limit. Hundreds of Eskimos succumbed to the scourge, as did many of the white population. Of 250 Eskimos, 200 passed out. With their primitive, unhygienic way of living, coupled with their superstitions and the intense cold, they had no chance against that direful epidemic, which, in their case, closely resembled the black plague. This was the most terrible affliction Nome. had experienced for many a year. Relief parties, hurriedly organized, went to the distant igloos scattered around the outlying districts, and it was not uncommon to find a whole family half frozen. The older members had been stricken, and there were none well enough to chop wood or make a fire, nothing for them to sustain life upon. I saw one child who was brought to the hospital. She was found in an igloo with a baby sister clutched to her little thin breast. They found her sitting there, starving, her own wee limbs frozen. The baby which she nestled so carefully was dead, as were both her parents. Her legs had to be amputated, but fortunately she has recovered, and false limbs are being made for this tiny heroine. 
It was practically the same in many igloos; the Eskimos were all down with the 'flu-dead, dying, and frozen. Those who still maintained a spark of life were conveyed to the hospital, and the entire town waited upon the natives. A lady related to me that the circumstances, climate, and conditions generally were beyond description. Everyone became possessed of a creepy, ghostly dread; it was as if Death the Reaper was ever beside one. She herself got into such a nervous state that she dared not go into her own cellar alone, or past empty houses. Every day a waggon heaped with frozen dead, packed like logs of wood, passed her door. Many dogs had to be shot, as they patrolled and consumed the dead. The stories of last winter's plague were too depressing to listen to, and one can well imagine the horrors which the Nomeites experienced. Some sisters died, others were worn out, as they had worked with all their might. Those who survived have been transferred to another branch of the Holy Cross Mission, as the hospital is now closed. Near the hospital is Eagle Hall, a huge building where many varied social functions are held. I was attracted by a large painting which depicted a fine malamute dog-team mushing through the snow. It is quite an arresting work by a local artist. The Pioneers also have a hall, and there are many fraternal orders, including the Miners, Pioneers, Eagles, Oddfellows, Knights of Pythias, Masonic, and Social Club. Many of these have libraries, which are greatly used and appreciated in winter. We visited the Lavinia Wallace Young Mission, two buildings opposite each other, one devoted to the elementary education of the Eskimo children, the other a workshop where different trades and all sorts of useful occupations are taught. A hospital also forms part of this admirable institution. Mrs. Young had been for many years secretary to this charitable mission, which was subsequently named in her honour. The philanthropic donor was a wealthy lady of Pasadena, California. Mr. Baldwin now has the work in hand, and the Methodist Mission support this good cause. Many of the children who are being brought up here are the orphans of the Eskimo victims of the influenza. These 
mites appeared very happy both in their schoolroom and in their commodious playground. They were healthy specimens of humanity, laughing, swinging, and enjoying themselves immensely. The Pilgrim Congregational Church -and here also the Methodist meetings are held-is sole representative at the present time of the Protestant faith. The St. Joseph's Catholic Church, presided over by the Jesuit Fathers, is well attended, and accomplishes splendid work, especially amongst the natives. Father $\mathrm{La}$ Fortune speaks Eskimo fluently.

I paid a visit to the Nome Tri-Weekly Nugget, the best newspaper in this part of the North. It is in direct communication with, and a member of, the Associated Press. Here I was genially received as a colleague by Mr. George Maynard, the publisher and owner, and $\mathrm{Mr}$. Charles Sandford, editor. During my stay in this chief port of the Bering Sea they were most kind and helpful to me, by affording me information and loaning me historical books of this immense Alaska, of which few people of the European world have much knowledge, except of the vaguest character. How many are they who mentally paint Alaska as a land of icebergs, whales, and seals, never imagining that the whole country at this time of the year-August-is aglow with masses of beautiful wild-flowers and wild-berries that can compete with countries enjoying more favoured climatic conditions. The delicate forget-me-not, the national flower of Alaska, blossoms in sheets of blue, and enwraps valleys and hillsides in picturesque splendour. Everyone visits the famous photograph-shop of the Lomen Brothers. They represent one of the pioneer families of Nome, and take a prominent part in municipal affairs. Their photographs are noted all over America as the finest procurable of Arctic scenery. I hereby acknowledge with thanks their kind permission to insert some of their artistic work in this volume. The principal social rendezvous is the "Alaska Dream Palace." This moving-picture show gives two screens a night, one at 8 p.m. and another at 9 , and all Nome congregates there. It is indeed a blessing for them, remem- 
bering that for eight months in the year Nome is snow and ice bound. But thanks to the wireless and the cinematograph, the "outside" world is brought, as it were, to their door. The town is interesting, and in the shops most of the things which go to make life comfortable can be purchased. As in other parts of the country, goods are necessarily expensive. The water-supply from Moonlight Springs, a few miles away, is plenteous and excellent. In winter, when King Frost holds land and water in his iron grip, the water is taken from the Snake River and peddled around town. The temperature varies from 40 below zero up to 70 , and higher occasionally. Blizzards are frequent, blowing up without notice and raging with ferocious intensity. Then man and beast must take cover, and often they lie down together on the trail. Each tries to keep warm and maintain the spark of life, for the frost creeps stealthily, and you unconsciously sleep, never to awake again.

\section{THE FAMOUS BEACH AT NOME.}

\section{Nuggets of Goxd.}

Only a mother, wrinkled and grey,

Is left alone at the close of day;

Her sons are lying side by side,

And over them sweeps the Yukon's tide.

Alone in the night a young girl weeps,

While the world around so peacefully sleeps.

A father and lover's race is run

In that wonderful land of the Midnight Sun;

Only these words, and the story is told;

Loving hearts broken for nuggets of gold.

Mothers and sisters, and sweethearts and wives,

Waiting and watching with tear-dimmed eyes,

Waiting for news from the land of gold,

While a thousand fears turn the heart's blood cold.

Happiness bartered, and innocent lives,

While forms grow bent and tears dim eyes;

Loving hearts broken with sorrow and care

That seems too much for them to bear,

And faces grown worn and haggard and old;

Are they worth the price, these nuggets of gold?

These are some fragments I found at Nome. I cannot thank the author, as I do not know who wrote the lines, but 
to me they appealed, I having seen and heard so much of the hardships, sorrow, and death caused in the endeavour to win these same nuggets of gold.

Standing on that historic beach of Nome, and gazing out on the sunshiny waves rolling in from the Bering Sea, that vast expanse of water which for more than half the year is locked in ice, my thoughts return to 1898 . I try to picture this lonely beach as it was then and for the years succeeding that great inrush of people seeking for the gold. The Nome stampede created more furore than any since the gold discovery of the Klondike.

On this beach where I now am some 20,000 poople landed, and lived on the sands, there being no other accommodation. Merchandise of every description was piled to mountainous heights, and tents, huts, anything for shelter, were quickly thrown together. One had to pay 10 dollars an hour for a horse and waggon to haul possessions farther back from the encroaching tide. In those placid waters, now glimmering in the August sunshine, as many as seventy steamers rocked at one time, each crowded to the limit. All had dumped their passengers on to this golden beach, where anyone with a pan might wash out the precious metal. Prices became inflated beyond the dreams of reason. Wondrous were the stories told of lucky ones who had picked up nuggets from 50 dollars to 500 dollars in value. Exaggeration was in the air, fanned by greed. It was "No Man's Land" for a time. Two men, it was said, rocked out 4,000 dollars' worth of gold in three days. Lumber was almost priceless.

Soon this wilderness of desolate beach blossomed into a tent city; shops were opened under canvas, and the wares they sold were blatantly painted on the sides and roofs. Money was of no consideration, for gold-dust and nuggets lay about everywhere. You had only to dig, wash, pan, and rock gravel, and opulence was yours. Ships were continually arriving, bringing old-timers and young miners, men with capital, women hoping to make some, gamblers and crooks from every other mining camp, so-called "theatricals," inglorious prostitutes, and adventurers from all over the world. 
Everyone was gold mad. One wonders if Satan did not look down upon his followers and grimly smile.

During September in the year 1898, Jafet Lindeberg, a young Norwegian, who had come to Alaska in connection with the reindeer herds, and his two friends, Eric Lindblom and John Bryntesen-the latter a Swede-were strolling along, maybe with the idea of doing a little prospecting. As Mr. Lindeberg's father owned copper mines in Norway, and the young man had already travelled in Siberia, he knew something of mining. At Anvil Creek, about 10 miles from the beech, Fortune beckoned, and led them to the richest placer gold discovery of the world. This land had rarely been trodden over; only a few straggling Eskimo tribes had invaded its savage wilds, and they never dreamed that under the tundra was concealed hundreds of millions of dollars' worth of virgin gold. Who could have predicted that within this wilderness of barren waste, upon which not even a tree could obtain sustenance, Mother Nature cradled under the spongy moss and blossom-spangled grass treasure untold? But it was so. After Messrs. Lindeberg, Lindblom, and Bryntesen had extracted 1,800 dollars' worth of the metal, they returned to the Swedish Mission at Golovin, where Mr. N. O. Nultberg, a Swedish missionary, had a few years previously established an industrial school for the Eskimos. Here, in September, these lucky young adventurers passed the winter, and were obliged to remain inactive until the following spring, as nothing in the way of mining could then be done in an icecapped territory which, from the North Pole to the Bering Sea, wears a white mantle of snow. Before long news of the gold strike began to reach the outside world, and miners arrived in legions. But it was not until 1900 that the mighty stampede set in-that torrents of humanity drifted to these golden sands. On this beach men and women worked tirelessly, rocking and panning, some pans yielding 100 dollars to the pan. The gravel formation of mica schist, and full of gold, is found in the beds of streams, where it has been concentrating for centuries. The gulches which seam the hillsides have yielded immense fortunes to lucky prospectors. 
From the Pioneer Mine, which leads the Nome production, more than 18,000,000 dollars have been extracted. Claims were staked in the early days amidst much wrangling, and costly law-suits followed. The Pioneer case, for example, occupied the courts for some time, and was eventually decided in favour of Mr. Lindeberg, who founded the mine. Great wealth has been extracted from the Anvil Creek, Dexter, the Bessie, Dry, Glacier Creek, Snow Gulch, the Wild Goose, amongst other rich claims. In the first days of the wild scramble people had not the least notion what to do with so much money. Gamblers flourished, as did countless bars and dance-halls.

Yesterday I had a caller; she announced herself as " the Mother of Nome." Mrs. Tiffany is her name, and she described to me this beach as she first saw it. Mrs. Tiffany was one of the first women to land at Nome, with the added advantage of being a cook. In her tent she used to bake innumerable pies, which were auctioned off. Men thought, she said, nothing of bidding 15 dollars and 20 dollars for a pie, and when she made a decorated frosted lemon-pie she could easily sell it for 50 dollars. Accompanying her to this Northland was her young and pretty daughter, "Tootsie." Mrs. Tiffany acknowledged that her daughter, who had no lack of admirers amongst the rough crowd, was a great anxiety to her. They lived in a flimsy tent on the sands, and when they retired for the night, the only means of ensuring privacy was by pinning together the flaps of the tent with safety-pins! For a bedstead "Tootsie" slept in an empty piano-box. Everyone lived in this nomadic style, yet 50 dollars for a bottle of champagne would readily be paid, and huge quantities of this wine were consumed. People were pouring in, and boat-loads of miners fresh from the Klondike hoped to find the rich claims which had escaped them up Dawson way. Mrs. Tiffany recalled how the desperadoes and scum of mining camps had assembled at this Mecca. She was not afraid for herself, but for her daughter.

A man had for some time been forcing his attentions upon them, attentions which they had discouraged in every pos 
sible manner. One night came the climax. The man, having primed himself with alcohol, appeared before her frail tent and insisted upon entering, Mrs. Tiffany called out : "If you dare to come in here, I'll maim you !" He replied : "Hell! What, can you shoot?" She answered: "I have warned you, and mean it." $\mathrm{H}_{\theta}$ burst in. She shot him, and he fell, and nearly died. She had wounded him in the thigh, and he walked lame for the rest of his life. For many years after that episode Mrs. Tiffany was called "the Gun Woman." After this manner, rough, common, devil-maycare, was the life of Nome, the richest mining camp of those days. Graft, robbery, and all vices reigned unhindered. After a time this city of tents gradually transformed itself into well-laid-out streets; frame houses were constructed. Law became recognized, and Nome emerged from its unlovely chrysalis stage into the capital of the Seward Peninsula. During the summer months business is extremely brisk, not only at Nome, through which port every commodity arriving at, or leaving, the district passes-an enormous trade in furs is carried on with Siberia-but at the other mining towns at Council, Candle, Dickson, Bluff, Teller, and Deering. Nome's voting population is some 500, and about 1,000 souls make this their home. The open season brings in addition many people who return to reopen business, grizzled prospectors, sourdoughs and cheechakos in quest of the Golden Fleece, or, as a local wit expressed it, the "Golden Froeze." Of tourists there are only a few who wish to see a country different from any other and off the beaten track. The winter season is by no means dull, as business with the "outside" is suspended, and the people unite like one big family, giving themselves over to enjoyment, cardparties, dances, ski-ing, driving dog-teams, and other amusements. The celebrated dog-team races, which are chronicled all over the States and Canada, and in connection with which huge stakes change hands, make the long, trying winter pass quickly. But the first steamer from the "outside" is eagerly awaited, so much so that a festival is arranged and people even venture out on the ice as far as safety allows, 
to greet the first visitors and hear their news. The Nomeites tell me they delight in fresh fruit, bananas especially. After eight months of tinned fruit, the fresh article tastes unusually palatable. The Reindeer Fair, an annual winter pastime, takes place at Hot Springs, some 60 miles from Nome. Around these famous springs, in frozen Alaska, vegetables can be grown all the year. The contrast is most remarkable. Here in the snow area you suddenly encounter abundant vegetation, veritable oases around the boiling Hot Springs. Such is the Nome of to-day. 


\section{CHAPTER XIX}

\section{ESKIMOS: HABITS AND DANCES}

ITEMs from the most unique newspaper in the world; it has the distinction of being the only yearly journal :

\section{"THE ESKIMO BULLETIN."}

\section{Cape Prince of Wales.}

First whale of the season was harpooned to-day. It is a calf, 25 feet long. It took four harpoons to puncture it.

\section{Battle with Walrus.}

A herd of walrus took possession of an island in the small Diomedes. The Eskimos killed the most of them with lances, thereby ensuring tons of food for the winter.-ALL EsKIMOs VERY GLAD.

Could we get our daily journals reduced to the conciseness and brevity of this Eskimo annual, how much valuable time, labour, and eyesight would be saved!

The United States Government do not allow white men to hunt the walrus. The law decides that the walrus of the Arctic regions shall be reserved for the maintenance of the natives. The oil has no commercial value, and it would be unfair to permit white men to slaughter the walrus when they only use the tusks and waste the remainder, and when it is so much needed to sustain the life of the Eskimo in these frozen zones. On the other hand, the Eskimos utilize every part of the carcass. When Captain Cook was out in the Bering Sea, in 1776, he described the walrus as "sea-horses," and ate them, and wrote that the cooked heart of a walrus was as palatable as that of a bullock. The hide of a walrus is valued at more than 100 dollars, and the weight of an extra large bull averages from 180 to 200 pounds. The skin is from $1 \frac{1}{2}$ to 2 inches thick. There seemed to be two layers 
with a fat streak between, and a dollar a pound, and more, is easily obtained for it. About 30,000 pounds of tanned walrus hides are imported into the U.S.A. annually. These hides are utilized by silversmiths for the making of the wheels used in the polishing of metals.

The Eskimos construct boats out of the skins; the oil supplies both food, fuel, and light for them. The meat they love; the bones constitute the framework of their sleds. Parts of the intestines they preserve and eat as a pickled tripe. The other parts are scraped and allowed to dry, then made into raincoats and hanging pockets. They also use it as window-glass, or place it over the chimney hole of their snow-block igloos. When bellowing herds of walrus-they issue a sort of bark, also-appear in the Bering Straits, the Eskimos go forth in their walrus-skin boats (kiaks, podiakis, or oomiaks), or wait on blocks of ice, to harpoon these monsters. The Eskimo can eat enough at one meal to suffice him several days. On an average he consumes five quarts of meat and soup, then follows a buckhorn cup of bear-oil, after which comes repletion. The Eskimo woman does not eat so fastidiously as her sisters of other climes. She will take a dried salmon and dip it in seal-oil, crunching it vigorously without bread. Or if she has fresh fish, she will pull out its entrails, hold it up as some people do asparagus, then let it gradually into her mouth-a disgusting performance. The Eskimos are an aboriginal race, fisheaters all. While the war was on, the Eskimos, who had masses of eiderdown hidden in rocky caves and other natural hiding places all over the North, as far as Point Barrow, 300 miles northward, procured the treasured down, stuffed it in old rags, garments, parkas, or anything they could find, and sent it through Nome to Seattle, and thence to the Red Cross. Many a wounded soldier with a down pillow under his head had cause to thank these primitive Eskimos for this additional comfort.

The Eskimos also had their Red Cross badge. It surely would have gained a prize for originality - a small round disc of white reindeer skin, upon which, stitched with seal sinews, 
was a red cross formed out of red leather, native-dyed; around this disc circled a wreath of reindeer fur. It was not at all unsightly-simply crude. This emblem I was presented with, as a souvenir. The Eskimos were most dolighted with the photograph postcard of H.R.H. the Princess Mary which I happened to have with me. They took the greatest interest in the Princess's likeness, talking gleefully amongst themselves in a tongue which meant nothing to me. Then they lapsed into their so-called English, and wanted me to take another of their peculiar Red Cross badges and convey it to Princess Mary. I smilingly agreed, mentally wondering what her Royal Highness would think of the Eskimo offering. However, a promise is a promise. I sent the Eskimo Red Cross badge to the Princess in London. She graciously accepted it, and a charming letter is now in possession of one of the principal citizens of Nome. The Eskimos are delighted, and demand to see and have the King of England's daughter's letter read to them over and over again. Thus has the popularity and gracious kindness of our Princess reached even the remote peoples of Eskimo Land.

\section{The Eskimo Dance.}

Word was passed round that the Eskimos of Cape Prince of Wales and King Island, then summering at Nome on the "Sand Spit," were to have a "kozga," or dance. My friends and I piled into a motor, and proceeded along the beach towards the Nome River, where the Eskimos were encamped. They are cautiously silent about their dances, and even the Nomeites were anxious to see the evolutions of these stranger natives. It was not necessary to inquire the way, as a line of people were bound for the same destination. The declining sun painted the sapphire sea with a long broad path of shimmering gold; purple clouds formed the northern background, and caught the blazing colours of the departing sun. Imagine our surprise to find an impromptu ballroom arranged by placing three large walrus-hide boats, the "oomiaks," sideways up. For a roof the Eskimos had stretched their 
sails partly across. It was fortunate that the glorious sky formed a natural dome, as otherwise the aroma de Eskimo might have proved too pungent even for a thoroughbred traveller like myself. A curious and lovely effect was produced by the setting sun as it shone on the mottled walrushide boats, making them semi-transparent, and like tortoiseshell. The waves that rolled along the beach within a stone's throw of the ballroom, whispering gentle music, added to the effective scene. We entered, pushing open the canvas tent flap, and a strange picture was encountered. At the side of the tent, fully fifty Eskimo women sat on walrus hides-in fact, the entire tent was thus carpeted. The women wore their best parkas, and very handsome these garments were, made of the dark-brown reindeer fur, trimmed with tassels of fur and white deerskin. At a distance it looked as if they were wearing priceless sables. Their faces were well washed, in honour of this important society function, their hair brushed and braided, long braids hanging each side of their bright rosy cheeks, their dark eyes sparkling with excitement. From the wolverine-lined hoods of the parkas babies showed their small faces-some asleep, while others solemnly eyed the proceedings./ How safe and warm these babies rested, held tight against mother's back, while the mothers squatted on the hide mats, keen to watch the dancers. Across one end of the tent was placed a wide board, and sitting upon this impromptu stage were twenty young Eskimo girls, the dancers. They had removed their parkas, and their habiliments were indeed curious-loose cotton blouses, old jerseys, slips, underdrawers, and vests. However, in their own minds they were quite comme il faut. The expression on their faces was most serious, as if about to engage in some ancient ritual. In front of the dancers, sitting cross-legged, were ten young men: they were to supply the music, the hoop-enclosed seal bladders already described. The first dance was intended to represent the hunt, and the chords struck resembled, " $\mathrm{Ah}, \mathrm{Ah}, \mathrm{Ah}, \mathrm{La}$ $\mathrm{La}$," in monotonous cadence. The sitting girls began swaying their bodies only, the feet remained passive; there was 
a great amount of wagging of heads. Peering after imaginary big game, they gesticulated with their hands in time with the music. They were most serious, not a smile, as intently they watched the leading woman, who sat at the head of the broad board, and followed her terpsichorean gyrations. Slowly they rolled the-body from the waist up; then with their arms they mimicked the hunt-how they searched for the game, peeping with bent heads for illusory deer, then waving their hands backward and forward; you could follow by their clever pantomime exactly how the hunt was progressing. Their entire thoughts were on the chase: they never noticed their audience in the least. At the close they broke into laughter, as the mystic deer was supposed to have been run to earth. After this hunt dance, I amused myself by studying the faces of men and women. The men bear a distinct resemblance to the Japanese : dark, straight black hair, brown skins, black eyes, high-boned dark-red cheeks, and the characteristics and expression of the Mongol. The women are much better-looking than their men-folk. Some were pretty, and had dazzling white teeth. They wore many bead bracelets-blue appeared to be the favourite shade-and ivory mastodon ornaments. They seem a docile, pleasant people. If you smile at them, they will return the smile with generosity; they are proud to be noticed.

Now another dance begins. A man and woman stand up; he dons seal gloves, for this, they tell us, is to be a seal dance. The tom-toms are banged, and the man and woman lead, while the girls also take their part, still seated. They point to an imaginary seal upon the ice-more beckoning and peering into space. All the movements of the seal are reproduced, and finally the seal is harpooned, amidst great rejoicing. Then they prepare a feast; all this accomplished without a word being uttered. Again I turn my attention to the Eskimos squatting before me in their sable parkas. Not a baby has whimpered; but Eskimo babies have long since discovered that bawling is a waste of energy; the mother simply does not bother. I discover amidst the crowd an aged woman who is minus a nose, and my friend tells me 
that the husband had bitten off that member in a quarrel! In olden times this was their method of fighting: each tried to bite off the other's nose! Hence this woman's lasting souvenir of a broil with hubby.

One man springs up, shouting. I look up, startled, but am told that "the spirits are moving him." He wriggles his body in agonizing contortions, then subsides. The headman, Master of Ceremonies, now dons another pair of fur gloves or mittens, wearing with each dance a different pair of gloves. This is the rain dance. All hands and arms now denote falling rain; they cover themselves, now they seek imaginary shelter. The tone of the music rolls out in cadences, which might be interpreted as, "Hallo! Hallo! Hail !" The girls wriggle appropriately until the rain dance ends.

Between dances, as in the best regulated society, conversation is indulged in. "The man over there," says my friend, "last winter found his toes and a part of his foot frostbitten. No medical aid was handy, so the poor man hacked off the frozen part without any anæsthetic, his own nerve sufficing; and now he ambles about on two queer-shaped stumps." Another dark, swarthy man, sitting near me, had an uncle. They lived on the Diomede Islands, where there was a Government school, presided over by an American master. Now, the Eskimos get into a furry if they see children beaten, on account of their belief as to reincarnation. The uncle of my neighbour had a son at this school, and the master beat him rather severely. When the man heard of the treatment meted out to the child, he went to the school and shot the master. Then the tribe held a council, knowing they would be punished for the death of the U.S. Government teacher. They marched the murderer to a secluded spot, made him dig his own grave. He then chose his nephew, the dark man seated near me, to shoot him. Thus was justice done. You would never imagine that this quiet Eskimo, so intently watching the dancers, had passed through so tragic an ordeal. A custom of the Eskimos when they become old and infirm, and can neither fish nor hunt, and only live and eat from the 
labour of others, is to choose the manner of their deathusually drowning, shooting, or hanging. They appoint one whom they wish to give them release from life. As a rule, it is a son, or near relative. Many of the tribes when old much prefer to be put out of the way and join the happy hunters in the other world.

On with the dance! Now a crane is wooing in the spring : this is the only stand-up dance I have yet seen. They. imitate the advancing of the bird, sometimes on one leg, then on another, the flapping of its wings, the calling of the crane to his mate, and the general hullabaloo. The next item on the non-existent programme is most cleverly enacted by an old woman, the young girls only accompanying by occasional gestures. Madame Eskimo is supposed to be gazing across the sea from her igloo. She sees an anchored whaling ship surrounded by floating ice. The idea comes to her to investigate. She pulls off in her kiak (small boat), all the movements of paddling being plainly seen. The girls assist her, as if in chorus. She arrives, and by the help of a rope-ladder flung over the ship's side, climbs on board. The smiles of welcome and the accompanying grimaces are quite funny. The old Eskimo enjoys this dance, and by the very realism of her " turn" must have experienced the incident some time in her existence. They give her drink, then another, and a third. Then she becomes very excited, and dances, shouting in glee, the effect of the stimulant. She staggers off the boat, clings to the rope-ladder, reaches her kiak, and paddles back to her igloo. She becomes very sick, and sleeps. Next morning she awakens with a bad head, goes out and rubs her head in the snow.

This Eskimo woman was a real actress, and so clever was her mimicry that you followed her story simply by her expression and gestures. She gave one a faithful representation of what such a woman would do under the circumstances. I have since thought what an acquisition Madame Eskimo might have been to the films!

One dance we laughed over until it hurt-a dance I shall never forget. It was a cootie dance, or wriggle. It was 


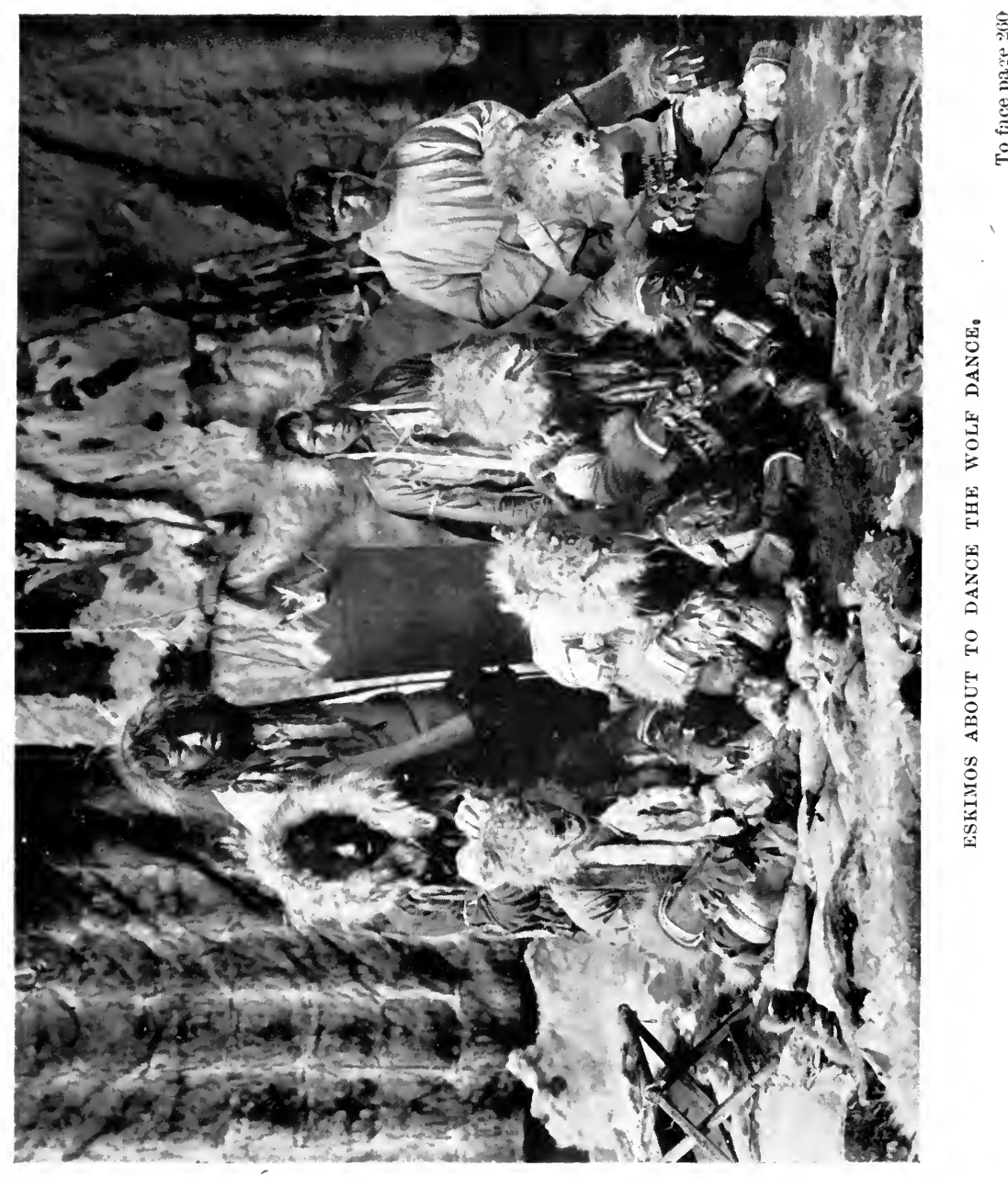



short, but most effective. An old woman stood up, wearing what might be described as a yellow shirt and trousers. The tom-toms began softly, the woman searched anxiously, aggressively, in the folds of her skirt. Cautiously she twitched, then looked, shaking herself all over. Then she mimicked a cootie (a body parasite) crawling, her movements keeping time with the music. Then a big jump, and a look of triumph, as she victoriously held forth the imaginary tormentor. She took it in her hand, then a clap-a big bang from the tom-toms-announced the death of the cootie. This was greeted with wild yells and laughter, and the old woman sat down, well pleased with her success, nodding her head in acknowledgment to the audience.

It was a picture, this assemblage. As I looked over this strange collection of humanity, the natural, crude surroundings, the women in their parkas, the babies peeping from the hoods, the dancers perched upon the planks, and the dark, excited faces of the men, I was sorry to think that in the art galleries of the world which I have visited never yet had so striking a scene been pictured. What a sensation a picture such as this, faithfully portrayed, would create, could it be hung on the walls of our own Royal Academy! For the artist, Alaska is a rich and practically virgin field. I offer this suggestion with the utmost confidence to our R.A.'s in embryo. 


\section{CHAPTER XX}

\section{A TRIP TO THE PIONEER MINING COMPANY}

WE started out to motor to the mines by way of Little Creek, over the vast tundra wastes and decomposed moss, passing masses of long waving grasses surmounted by the silky cotton-flower, which, in clusters, suggest pompoms of white silk. In this thick vegetation were to be seen thousands of deep-purple irises and the Alaskan flower, the pale-blue forget-menot, a beautiful national emblem. Its short summer notwithstanding, Alaska can show no fewer than 250 varieties of wild-flowers, and it would seem that in this frozen land Nature had done its best to atone for the long.spells of bitter weather. One specially notices the wonderful shades of blue to be seen on the mountains and the Bering Sea-sky, clouds, and shadows range from purple to blues, a real orchestra of colour. If the day be grey, then all the landscape is equally beautiful in its miscellaneous tints of grey. On the occasion of our visit the sun was shining and the blues were laid out by Nature in a fashion both lavish and seductive. Over on the Sawtooth Mountains spiral wreaths of cloud lay in fantastic arrangement. Here is the brown summit of Anvil Rock, shaped like an anvil, upon which many thousands have gazed and wondered if the mountain were destined to yield the precious metal. Some have found their El Dorado in the shelter of Anvil Rock, and Anvil Creek has poured millions into fortunate pockets. Not a tree is to be seen over this vast tundra stretch. Way off there in the distance they point out Rex Beach's red-roofed, deserted cabin, overgrown with weeds. Scattered about are the little lonely cabins of miners. We pass some dredgers, which are not working, a solitary tiny road-house, then turn a corner and motor over the Bessie claims. Millions have been taken 
from Bessie. To one not conversant with the wealth of the country it would be the most natural thing in the world to exclaim, "What a worthless-looking lot of land, a decidedly dreary place!" It seems like a dream when you look over all these 150 acres, and they inform you that at least $10,000,000$ dollars' worth of gold lies underneath, and perhaps far more! We are now at the Pioneer Mine, the richest, from which since 1898 some 18,000,000 dollars have been extracted. We dismounted at the mess-house. Mountains of tailings, dry and useless, resembled pyramids in miniature. Down below was the vast "Glory Hole," as they call it, from which wealth in millions has been taken, and will continue to be taken. It is estimated that this large property has enough payable gold to last at least thirty to forty years. Mr. Stephenson, the manager of the company, conducted us over the mine, Senator Heckman, with Representative Frawley and several others, being of the party. We shuffled down the slippery mass of tailings to the bottom, where the giant hydraulic monitors were working. We saw three in action; sometimes the Pioneer has seven or eight at work. We paused beside Giant No. 2 with its 3 - - -inch nozzle-4 inches is their largest-with 330 feet pressure. Through this nozzle a torrent of water is forced with such strength that it would decapitate a man should he get in the way! A miner simply points the nozzle at whatever ground or gravel he is at work on, and all is disintegrated. The method employed here is that of the hydraulic elevator, and it operates exactly the reverse of the hydraulic motors which I saw tearing down the Bonanza Reef at the Klondike. After the gravel, stones, and water are forced up into the sluice-boxes, which are lined with steel riffles 2 inches wide, the water again separates the gold from the waste, the gold collects on the turrets of the riffles, and the rest is rushed away. The force which these giant volumes of water generate can be imagined when, by suction, stones 13 inches in circumference are rushed up into the sluiceboxes as if they were gravel. I was told that when they arranged a "clean-up" in the sluice-boxes probably some 
250,000 dollars' worth of gold would be taken out-sometimes the contents represent as much as 800,000 dollars. Water is a really vital factor in mining here; the miners pray for rain, without which there can be no work. Immense sums must therefore be spent on ditch-building and other systems of water conservation. The Pioneer Co. controls a water-supply comprising nearly one hundred miles of ditches and pipe lines, enormous siphons being employed to carry water over miles of creeks and gulches. The cost alone of constructing this system was over a million dollars. In this vast area of alluvial gravels the ground has first to be prepared and thawed. This is accomplished by pipes which bore down with hot steam through the mossy tundra to bedrock. Then dynamite is applied to tear up and sunder the ground.

After our inspection of the Pioneer property we were all permitted to select a pan and wash gold in the lower creek, all the gold we washed to be ours for a souvenir. Now, in the earlier days enormous nuggets were found around Anvil Creek, upon which, and continuing for many miles, the Pioneer is situated. One huge nugget of pure gold was valued at 3,300 dollars; another realized 1,800 dollars. Both nuggets are owned by Mr. Jafet Lindeberg, and form part of a most valuable and unique collection of various golden souvenirs from Alaska. I do not think that any of us anticipated the luck of Midas; indeed, after our back-breaking efforts, and adopting the prospector's method elsewhere described, the resultant dust would only have represented a dollar's worth of gold. This we laughingly enclosed in a paper to be exhibited to our friends. In motoring back, we went over the first, second, and third beach.

I heard this story of two brothers, the Connollys, who own a rich gold-bearing claim, which they have named their " Reserve Bank." They turn up occasionally when they need money, and work the claim for a time. After they wash out as much gold as they think necessary, they simply leave Alaska for a long trip. During a visit paid by these lucky brothers they, in six weeks, obtained from their mines 
72,000 dollars, then disappeared again for more pleasure. Their claims are guarded, and they only work them when they feel so inclined.

I was shown a small space only 100 feet wide from which wealth totalling over a million had been taken. Such is rich Alaska; but at the present time, with expensive machinery, no less expensive labour, and inflated prices for food, unless the mine is very rich it does not pay to work it. It can readily be understood that the working of a mine under such conditions involves an enormous capital outlay.

After this visit I frequently went out to the Pioneer Mine, as I knew both Mr. and Mrs. Lindeberg, and they were both very kind to me. Mr. Lindeberg, as already narrated, was the discoverer of gold in Alaska on Anvil Creek, and is the largest owner of the property. One evening Mrs. Iindeberg, the manager, and $\mathrm{I}$, dined at the mine with the men in their mess-house. We sat at the head of the long table, with some seventy men ranged along each side, and partook of the same meal, which was cleanly served and most generous. The menu comprised soup, great heaped-up dishes of beefsteak, masses of mashed potatoes, beans, beetroot, pickles, brown and white bread, stewed apples, prunes, and two kinds of cake, coffee and tea. I thought of our English rations during the war, and the 1s. 4d. worth of meat per person each week. The Alaskans "feed," as they call it, well, and Mr. Lindeberg insists, and sees to it, that his workers shall be looked after generously. These men were a mixture of Russian, Finnish, Swedish, Norwegian, and a few Irish. Their wages at present are 6 dollars a day, and as much food as they want. Another day Mr. and Mrs. Lindeberg and I motored out together to the Pioneer Mine, and en route inspected a large herd of reindeer which were corralled.

To-day Mr. Lindeberg is Nome, and Nome is Mr. Lindeberg. Every year he and his wife spend several months here in summer, living in the plainest, most unpretentious manner. There is not an Eskimo around Nome who does not love this distinguished man, who has been the making of Nome, and who takes a personal interest in every native. 
He knows each by name, and they on their part realize that if they want anything they need only come to Jafet Lindeberg. His house and office are always open to them; he sees that their reindeer rights are respected, and that the Eskimo is justly treated. It is quite beautiful to watch these queer dark faces when the "Master," as they call him, appears. They simply beam. I shall not forget the expression on the face of "Split the Wind's" mother when talking to Mr. Lindeberg-adoration was stamped all over it. "Split the Wind," it should be explained, was a fine, tall Eskimo chief, and a good reindeer herder. He had accumulated a little fortune of 800 dollars-quite a sum for a young native. Unfortunately, influenza claimed him, and his other relatires attempted to secure the money from his mother. It was Mr. Lindeberg who settled the difference. The Eskimos would far rather obey him than any Government official, regarding him as their "Great Man." There was a rumour one day that a certain white man, a sourdough, wanted to marry a young Eskimo widow, a lady who owned a fine herd of reindeer. They said, indeed, that it was the herd that had tempted the white fortune-hunter. Mrs. Lindeberg, in talking the situation over with me, remarked sadly, "Oh, my husband will be griered. Why doesn't she marry one of her own race?" This simply shows the real interest these good folk take in the well-being of the Eskimo.

Another day Mrs. Lindeberg and I went over to the kennels to inspect the dogs, most of them Siberians, handsome creatures, grey-white and black mingled. One peculiarity about the Siberians is that they have weird pale-blue eves, which gleam phosphorescently. They are smaller than the malamute, but can better resist the cold and pull a heavier load. The dogs, naturally, made a fuss at our approach. "Pretty Nellie" was indeed a lovely animal, as was " Kremski," among a splendid team. On walking back to the assay office we met Mr. Lindeberg, who had been down to the bed-rock, where he had panned me a little gold. This I considered wonderfully fortunate, bearing in mind that it had been panned by the man who had discovered gold twentyone years ago on the same spot, and on his own property. 


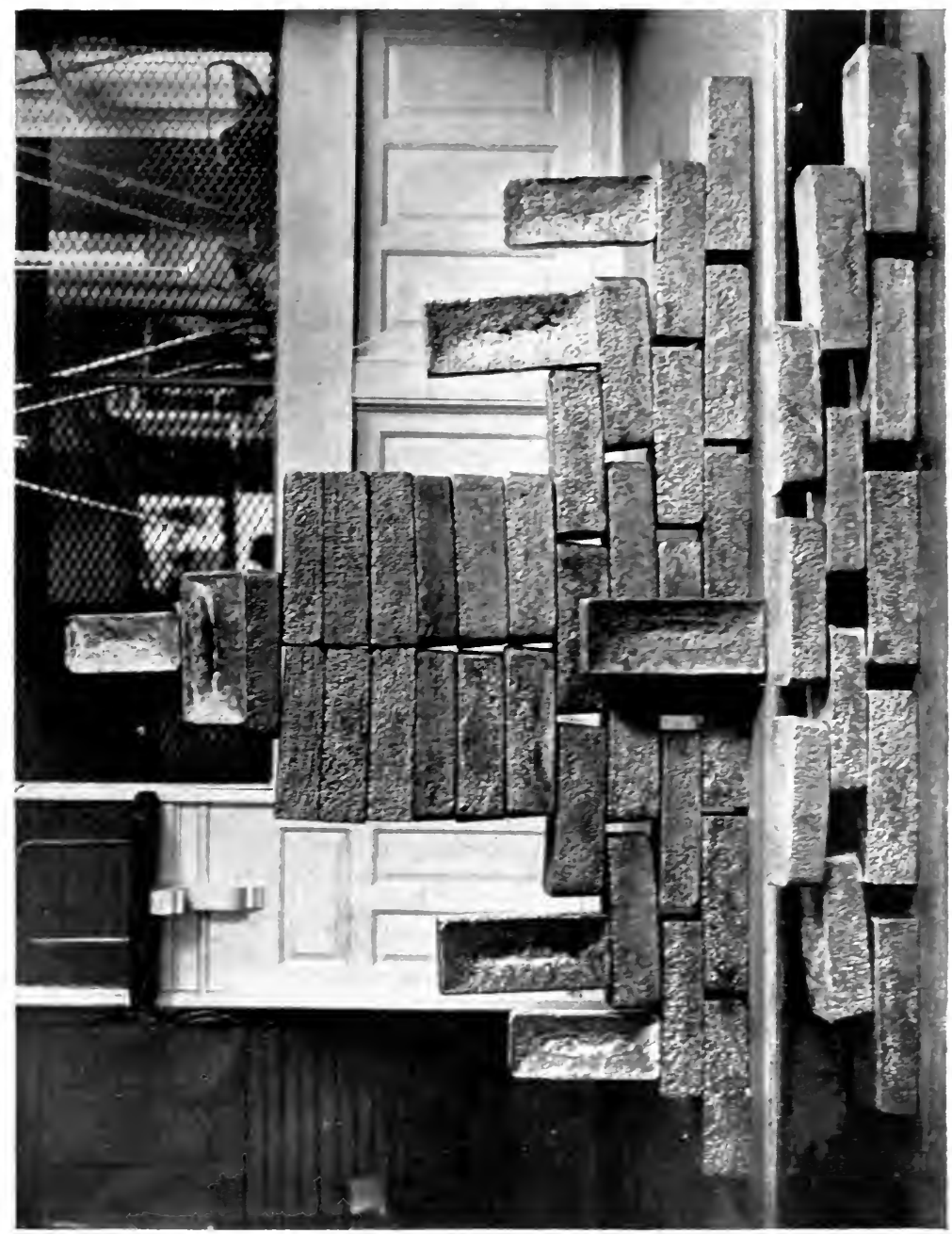

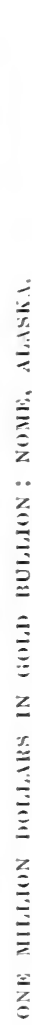





\section{CHAPTER XXI}

\section{SMELTING THE GOLD}

Have you ever seen gold being smelted? It was an unusually interesting process which I was invited to see at the Miners' and Merchants' Bank of Alaska. Arriving there, I was shown into a private room at the rear, where the heat was far greater than summer temperature. Mr. Kay, the " cooker" of the gold on this occasion, met me and apologized for not shaking hands, as he was wearing asbestos mittens! He led me over to the two smelting furnaces, which differed very little from the usual cooking range, with the exception that these had a sort of hood which could be moved up and down. With his pincers he raised the hood, and there, simmering in a heat of about $1,800^{\circ} \mathrm{F}$., was disclosed a graphite melting-pot full of liquid gold. It could best be described as golden soup. One's thoughts flew back to the legends of Cleopatra, who dissolved her pearls and drank them. Imagine a Iucullan feast of the gods, opening with gold soup, followed with pearl rissoles, and ending with crushed diamond soufflés! "Not cooked enough yet," laughingly explained our expert chef, as he covered up the pot. We then retreated to a cooler corner, where I was shown a lot of bricks already smelted. They were of various colours, some bright and light yellow in colour. One would have made an appropriate paper weight for a post-war millionaire! It was 500 dollars in value, and, although heavy, was not cumbersome. Its lovely shade was most attractive. Other bricks had more quartz, quicksilver, lead, and even tin mixed in alloy, which accounted for the variation in shade. These would again be put through the smelting process. Mr. Kay informed me that they could tell instantly from which district, mine, or creek the gold had 
been extracted. Picking up a brick at random, he explained: "This is from Dime Creek; some of our highest grade, value 19.80 dollars the ounce. Pure gold is 20.67 dollars, and about the usual assay is 18.60 dollars the ounce."

He accounted for the tin in the mixture by the multitudes of tin cans that had been thrown away in that locality in the course of two decades! The tin had in course of time been washed into the creeks of the placer mining and sluice-boxes. I was shown fine gold amalgamated with quicksilver, and many tin boxes of gold-dust, of every grade and size, from flakes to good substantial nuggets. Here was a shiny gold brick valued at 2,000 dollars. I held it as long as I cared to. It would have been no pleasure to have carried that any great distance. A base-bar attracted my attention. This originates in the different compositions which become attached to the riffles with the gold. It is a trouble to disperse the unwanted elements in the combination, especially if it happens to be lead. These base-bars the Mint must again re-smelter. The gold soup again requires Mr. Kay's attention, and we go over to inspect it. $\mathrm{He}$ affirms that it is cooked enough. By his side he has an iron mould which he places on the smelter, and oils and beeswaxes the sides and bottom. Now he takes a piece of graphite and, using it as a spoon, stirs the liquid. It boils up once more. Then with his big pinchers he lifts the red-hot pot off the fire and slowly, and with great caution, pours the molten green gold into the mould. The graphite pot takes on beautiful flame colours, just like a brilliant sunset, waxing from red to lemon shades as it cools. Now the iron mould, with its slag crust hardening, is put into a sink with running water. When cold enough to handle, the brick slips out of the mould, the slag crust is knocked off and put away with other slag. A little more hammering and scrubbing to clean it, and a shining gold brick is placed before me, valued at 17,000 dollars $(£ 1,200)$-not a bad potboil!

The slag substance is hard, black, and brittle, looking like lava, is full of the tiniest gold flakes, and is ground up and the small bits extracted. The smelting was not over by any 
means, and now the interest was even greater, for a 20,000 dollar brick was about to be fashioned. A larger graphite pot, into which much gold was poured, was put on the fire, the hood replaced, and the melting began.

Meanwhile I was conducted to the vault, or safe. Here, tied up in clean, strong canvas bags and labelled for shipping, were thousands of dollars' worth of gold. These bags were too heavy even to hold, and ranged in value from 18,000 dollars to 20,000 dollars, and there were five bags $(20,000$ dollars is approximately a hundred pounds in weight). Afterwards I talked to a man who had just brought in 22,000 dollars' worth of gold-dust. He appeared immensely glad to get rid of it and accept the bank's receipt instead. The dust or gold is weighed, then melted, and reweighed. In melting it loses a trifle, anywhere from 1 to 6 per cent., this depending upon the condition of the gold. The bank charges a discount of $2 \frac{1}{2}$ per cent., which represents their profit.

What with talking and seeing so much gold, time passes quickly. We return to see how the bigger pot is progressing, just in time to obtain a good view of Mr. Kay pouring the huge mould full of melted gold, and in a few moments we had the pleasure of looking at a 20,000 dollar brick. We attempted to lift it, and with our united efforts could barely raise it. Such bricks are perfectly safe so far as thieves are concerned. I saw over 200,000 dollars' worth of gold bricks ready for shipment. "They claim that in the Pioneer sluiceboxes some 300,000 dollars' worth will be taken out when they next " clean up "-perhaps more.

In 1906 Nome, in one short season of 100 days-they cannot count on more than that number of working days, on account of the climate-produced 7,500,000 dollars, which were sent to the U.S.A. More than the U.S.A. paid Russia for the whole of Alaska! In fact, Alaska has paid America in gold alone more than seventeen times its original purchase price. Shrewd, far-sighted Uncle Sam! 


\section{CHAPTER XXII}

\section{THE DOGS OF NOME}

The dogs of Nome played their part in the greatest war in history. In 1915 the French Government sent Captain René Haas over to the Arctic to secure dogs for work in the Alpine Corps for transport and life-saving in lofty, difficult passes, inaccessible to mules or horses. "Scotty" Allan, the principal dog expert, selected over 100 dogs from Nome, some from his own splendid team. About 1,200 dogs enlisted, so to speak, for the human cause, and, with their dried salmon food rations, were sent over those thousands of miles of snow and ocean, and nobly fulfilled their work in far-away regions, in the rescuing of men and in haulage tasks. Even the dogs of the Arctic did their bit for the undoing of the Hun.

Would you like to take a spin in a dog automobile? It is the greatest fun imaginable. It certainly was new to me. We had heard that a Mrs. Matherson owned a dog-team, with which she did teaming for the mines. Senator Heckman, his wife, Representative and Mrs. Frawley, and I, walked to the appointed place, where a narrow track began, and where ten dogs were waiting. On the track was placed a sort of double sled, with iron rollers for wheels, the two wide seats which protruded over the sides seating six or eight people.

Mrs. Matherson, a Swede, as broad as she was long, strong and ruddy of complexion, had the reputation of managing a dog-team as well as any man. She gave us a beaming smile, told us how to sit, called the dogs, and off we went, gaily and quickly. It was a curious sight, absolutely unique to me. Away they trotted, these dear doggies, just like jolly boys off for a lark-indeed, that was the appearance 
they suggested. They would look round at us with a grin, full of joy and excitement, wagging their tails and trotting. Sometimes they would break into a gallop, at which Mrs. Matherson would shout, "Whoa, boys!" Can you picture this narrow track and five span of dogs, each with a huge fox-brush tail waving over its back and flashing in the sunlight? They do just as they please, or what the leader thinks right. For instance, if they do not like the trail, off they go over the side, and run along off the track. At first a cheechako would venture, "Now we will capsize." Not at all. The driver applies a strong brake and the car keeps to the rails. One must have one's senses on the alert to successfully drive a dog-team. Each dog has its temperament, and requires ceaseless attention. "Blackie" is more frequently admonished, for he is the leader-a small black dog. Then in pairs come Frank and Sport, Smart and Baldy-the latter a namesake of "Baldy" of Nome, one of the most famous racers. Then Major and Prince, Shepherd and Jack, Dexter and Captain, while Jumbo, an old dog, runs along by the side of the car, just for company's sake. They keep up a good speed, and it is delightful bowling along over those tundra wastes, thick with blue forget-me-nots, purple irises, salmon-berry scrubs, and magenta fire-weed. In front of us, 30 miles away, tower the Sawtooth Mountains, showing many a tint from pinky lilac to royal purple, and dotted with shade and sunshine; alongside, the creeks, which have brought down millions of gold from the century-old concentrations of ore. Onward as ever they rush to join the blue Bering Sea, shimmering in the sunshine. We pass dredgers and hydraulics squeezing gold out of the frozen ground, but we care not for the gold to-day; we have seen and heard so much of it. To-day is dedicated to Nature. We arrive at some marsh lands with running water each side of the track. Off goes the leader, to splash in the water, the others following as a matter of course. Then all sit down in the water to cool off, looking back at us with laughing, panting mouths and a great wagging of tails. They drink and rest, rolling in the water, until Mrs. Matherson calls, "Come on, boys!" 
Up they get, like obedient children, and gaily take the trail again. The dogs are never beaten, or very rarely. If you cannot make a dog obey your wishes by kindness, you will never force him to do so by a whip, unless you break his spirit; then he is a nonentity. Usually they are allowed to do just as the spirit moves them. The only temptation to bolt comes when an impertinent wild bird flies over their heads, as one did, rising from the tundra without warning. It is exasperating for them to be in harness and have a low ptarmigan free to fly past and mock them. There was a pause, and consternation, when this happened. The dogs looked around, with an expression which plainly said: "You see that? Now, shall we go after it?" But we all cried out, "Oh, boys, good boys, go on; never mind the silly bird." They took our advice, dubiously, but went on. At Dexter Station we gave them a rest. The Sullivan ground was pointed out, where $1,270.00$ dollars' worth of gold had been extracted. Anvil Rock showed a different angle from this side, and one wondered how many more millions might be hidden in the heart of Anvil Mountain and the various gulches. Under the shadow of Anvil, so Mr. Frawley said, $1,800,000$ had recently been mined.

The "boys," having had their rest, came up laughingly to the call. It may seem ridiculous to say that these malamutes and dogs of mixed breed langh at you. But it is the only true expression I can find to describe them. Off we dash at breakneck speed, our driver guarding the brake with zealous caution.

For eight months of the year the outside world is cut off from Alaska-with the exception of the wireless telegraphand the mail is brought in from Valdez, 1,500 miles away, over the long frozen trail, by the United States Government dog-team mail. All transportation is done by dogs from Point Barrow to Labrador, with, in some districts, small assistance by the reindeer. In such a country dog and man are inseparable, working and chumming together. With the exception of a squirrel darting from the moss, which excited our " boys" somewhat, they have frolicked along right gaily. 
Now we come to a decline in the trail, and can coast down. The dogs are unhitched, to follow at will. Mrs. Matherson, our driver, takes the brake, and away we go, fairly making a record on our own speed, the dogs racing behind. Wonderful is the panorama of light and shade as we tear by. The dogs are far behind; all we can see of them is their tails wagging joyously just above the grass, like so many ostrichplumes. Some of our party were rather alarmed at our rapid coasting, but I had great faith in our excellent driver, and it was perfectly delightful rushing through the country, and at seemingly breakneck speed. We finally pulled up at a tiny road-house for lunch, and had not been long seated, when the leader, "Blackie,". dashed in, spent and hot, and lay down panting, for the day was warm. Then the others arrived in a bunch, still laughing and breathing hard, and soon stretched themselves for a "snooze" under the shadow of the house. It was the tiniest and most primitively quaint place I ever saw : one little room, another place just big enough in which to put some bunks, and a box of a kitchen. A real miner's cabin, it was kept by an old man who had been in England. He gave us coffee, bread, and cold reindeer for lunch. During the winter, he told us, he had been flooded out, and had to swing a hammock up high to sleep in. Now he had built a bunk over the stove, and hoped no water could get up that far. I asked the old cabin owner, "Why do you live away out here in this barbaric place, which must be cold, lonely, and even dangerous in winter?" He replied: "You see, I own a little claim. I don't want to leave it, and I just lives in hopes some of them capitalists will come along one day and give me a lot of poke for it-dems rich claims I got." That's the way with most of the people left out here. They live on, holding out somehow, for that great dream to come true; they wait for the old El Dorado days to come back again, the gold to melt and spread all over the land. Many have so waited, but the Great Power has called them to a land beyond, where gold will not buy all. I took some scraps of food from the table to the "boys" outside. They were not asleep any 
more; all arose to the occasion to get a share. When the plate had been cleared, I took a photograph of this strange habitation. The sides of the road-house or, strictly speaking, cabin, were covered with tarred paper canvas, studded with big shining nails. It certainly was an isolated spot, miles away from neighbours of any kind, with one old man dreaming his dreams of fortune to come.

The "boys" were soon hitched up again. It was quite a pull for them going up the trail, which we had coasted down so quickly and easily, but we let them take their time, with frequent intervals for rest. Whenever they saw water, which was often, they would take long drinks, and sit down to cool off. I loved to talk to them; certainly, if I lived in Alaska a dog-team would be my special delight, for I love dogs.

After the pull up, we again coasted for about 7 miles, and returned to Nome. The dogs always make a great show of speed when nearing the end of their destination. Thus we arrived in triumph, dogs laughing and their tails waving. We had travelled for over 30 miles, and if any of my readers ever reach Nome they can be sure of a joyous time on a run with the "boys." 


\section{CHAPTER XXIII}

\section{DOG RACES AT NOME}

THE greatest winter event at Nome is the dog races. The All Alaska Sweepstakes are held under the auspices of the Nome Kennel Club. Every man, woman, and child becomes intensely excited over the event, and for the time being the races, the entry of each individual dog, their history, temperament, and power of resistance form the chief topic of conversation. The dogs scent the sporting season. In summer they are tolerated, but during this thrilling period they are heroes all. Each leader trusts that his dog-star is in the ascendant, and that his team will beat the record of Johnson's 408 miles in 74 hours 14 minutes and 22 secondsa record which made such a stir in the North. Nome dogs are considered the best both for work and sport; and having, as a rule, the bird-dog breed in most of them, they excel in racing and endurance.

The Nome Kennel Club was organized in 1908, with Mr. Alfred Fink as President. The purses range from 3,000 dollars to 10,000 dollars. Large sums are exchanged in bets on the races; books are made on the dog races in Seattle and in all the big Western cities. The results of each lap are wired "outside" as the great race proceeds. The races are held early in April, and what bull-fights are to Spain, a marathon to the Greeks, Derby Day to England, so is the All Alaska Sweepstakes Dog Race to this vast Northland. Some young and pretty girl is chosen as queen for the fête. The queen, wearing the club colours, and dressed in richest furs, as are her ten attendants, arrives at the starting-point on her royal sled, enveloped in wolf rugs. She carries in one hand a silk American flag, in the other her staff, an ivory 
walrus tusk. The drivers and dogs-from ten to twenty dogs to a team-await her coming impatiently, with eyes keenly fixed upon the young queen, the dogs straining at their harness, longing to be off.

When all is in readiness the queen dips her flag, the word "go" has rung out on the clear, crisp air. The crowds cheer, and the first team fast disappears down the white trail, over a course of 408 miles, through sun, snow, and blizzards, and across the coldest regions in the North. The course is run along the telephone lines, so that all news is sent back as to the dogs' speed, their condition, and so forth, during which time the people continue to back their favourites. Candle, 204 miles from Nome, is the stop; the first half of the race is then completed.

Leonard Seppala, who shares the honour with "Scotty" Allan as the greatest champion driver of the dog races, told me that, according to the Nome Club code, the drivers must bring back every dog, dead or alive, to avoid any suspicion of cruelty. No driver cares to carry back a dead dog as extra weight, therefore every care is taken of them. A whip is usually tied to the sled in case of a fight with other dogs, but is never used on the racers. Just words are called out to spur them on, "Whoa!" "Gee!" " On, boys!" " Go for it!" etc. At the relay camps the dogs are fed, principally on dried salmon, rolled oats, and meal mush. Blankets are carried for them, green veils for their eyes to ease them from the blinding whiteness if the sun shines, and flannel moccasins for their feet in case the ice cuts them. When they sleep, the dogs and driver bunk together. The dogs are rubbed with alcohol, and receive attention before the drivers. . In his big races, Seppala said he slept scarcely at all for fear something might happen to them, lest they might fight among themselves. The racing sleds weigh about 30 pounds, and are usually made of hickory, tied and bound with walrus hide and reindeer sinews, and decorated with the various colours of the teams. The huskies have smart harnesses, and the tow-line of strong walrus hide is light and flexible. The driver urges the dogs on from his place on the 
handle-bars at the back of the sled. The dogs are harnessed in pairs, with one leader at their head.

What these dogs go through, so far as climatic conditions are concerned, can scarcely be imagined. The ice and snow are bad enough, but these obstacles are nothing compared with the mighty blizzards that sweep the country with scarcely any warning, blinding and covering both landscape and dogs. Wind and cold strike like steel knives, and there are times when even to breathe is harmful to the lungs. Under such circumstances these hardy, brave dogs, fighting the elements with ruthless perseverance, deserve their roaring welcome when the winners come trotting in through the crowded thoroughfares of Nome, where everyone who can walk has come out to greet the winning team.

"Sootty" Allan holds this record. His record in the All Alaska Sweepstakes is three times first, three times second, and three times third. "Scotty" Allan's famous leader is named "Baldy." Leonard Seppala is fast taking first place as a driver; he has proved himself to be the equal of "Scotty" Allan, who is known throughout the world as " the king of the trail." Seppala, however, is very modest, and dislikes to pose as a hero. When a great ovation is given him, as he leads his winning team off the trail, he simply shrugs his broad shoulders, and says, "Swede's luck," that's all-heaping the honours on the shrine of Luck instead of accepting the praise to which his own resourceful driving and handling of the team entitle him. Seppala is a young Norwegian, strong, wide-shouldered, but not tall, with a thick crop of waving hair, eyes steel blue, with determination stamped therein. His Siberian dogs love him, as he does them. They came from the Kolomar River district, Siberia, and are beautiful, small, grey-wolf-like, with the most peculiar blue eyes, which glisten like blue gas-light when they look at you.

On the 21st of April, 1917, Seppala won the All Alaska Sweepstakes, and the following article I quote from the Nome Weekly Nugget: 


\section{“TENTH ANNUAL ALL ALASKA SWEEPSTAKES.}

"Nome to Candle and Return, 408 Miles.

"People came rushing to the finishing-point from every side, the majority of whom had stayed up all night awaiting the great event, and when Seppala hove in sight a mighty cheer went up. With cat-like tread, on they came, thoselittle Siberians, their eyes of palest blue glistening. Little would one think that they had just finished a 400-mile jaunt across a trail whose needle points would eat up the foot of an ordinary dog; and when they crossed the line, all stood up in their harness, and again awaited the word to go. The actual time out until the return of the winning team was 113 hours 34 minutes and 8 seconds ; taking out the time lost would reduce the actual running time down to 73 hours 34 minutes, which is below the record time set by John Johnson in 1910."

The Nome Kennel Club offers a purse of 10,000 dollars to the winner, 2,500 dollars for a second prize, and 1,000 dollars for third place. In addition to the purse of 10,000 dollars, the winner receives a handsome silver cup, which remains in his possession until such time as some other person may win one of the annual sweepstakes races, when it is transferred by him to such winner, and by him held until won by another person. The cup becomes actually the property of the first person who wins two of the annual sweepstakes. Mr. Jafet Lindeberg's trophies in the way of silver cups, including the famous Borden Cup, form an interesting collection. These were won by his Siberian teams, which were bought in Russia for the Amundsen Expedition, and driven by Leonard Seppala. Amongst the celebrated teams are the Allan and Darling, Fox Ramsay, Bergers, Percy Blatchford, H. O. Brown, Albert Finks, Crabtrees, Waskey and Contu's, Brown and McCarthy's, and others. In 1910, Colonel Charles Ramsay, of London, raced here, and from his sled the Ramsay tartan proclaimed that Scotland was competing. 


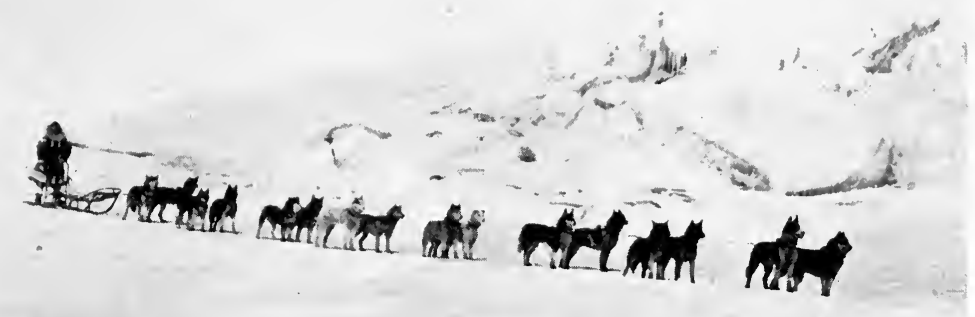

SEPPALA AND HIS FAMOUS RACING DOG TEAM.

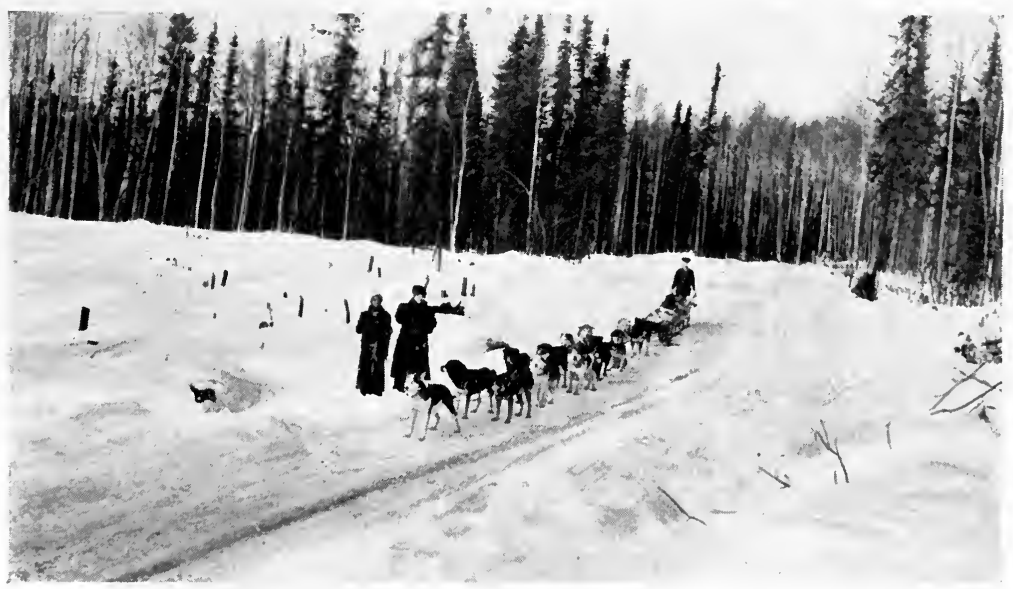

DOG MAIL TEAM NEAR FAIRBANKS. 

Stuart Weatherly, also of London, has raced a team at Nome.

I had the great pleasure one evening, just at sunset, to ride to Nome from the Pioneer property with Leonard Seppala and his famous Siberians. It was perfectly delightful, sitting in the small car and racing through the tundra. The setting sun cast a golden light over all the landscape, reflected in the stream that ran alongside our trail. The dogs were joyous, recognizing their master's hand, "Togo," the small leader, actually dancing gleefully. They were beautiful, this span of ten silvery wolf-like creatures. Sometimes every eye would turn to Seppala, and their red grinning mouths and glistening white teeth made a picture I shall never forget, as they trotted along, with " Pretty Nellie" following at the side, free. " Nothing can beat Togo," announced Seppala, with pride and adoration; then continued retrospectively: "Sometimes I think I would like to go home to Norway, but I couldn't leave that little Togo." At that instant the phosphorescent eyes of Togo gleamed as he turned at his master's voice. Off he galloped, gayer than ever. These dogs can do from 70 to 120 miles a day, according to condition and weather. All the way back Seppala told stories of his dogs, how the previous winter they worked for the influenza victims; how a man was practically cut to pieces by a saw-mill machine, one of his feet simply held by a thread. Seppala was 'phoned for to take the suffering man to hospital. The team ran out to rescue the victim, 106 miles without stopping, and brought him in. Imagine the agony of anyone, in midwinter, and after such a calamity, sustaining the joltings of a dog-sled for all those long miles. Yet it was the sole means of conveyance in this Alaska.

It can readily be understood how and why the dogs become such companions in this lonely, frozen land. Upon arriving at the end of my short trail, I thanked Mr. Seppala warmly for the pleasure of my ride, and said good-bye, for next day I was sailing for England, over 10,000 miles away. In walking down the road, I glanced back, and there stood Seppala waving his hand. Seppala and his Siberians were 
silhouetted like black velvet statues against the glory of the setting sun, so much more beautiful than "Glory Hole," just a few miles back, where gold in millions had been dug and transferred to the ever-yawning pockets of seldomsatisfied men. 


\section{CHAPTER XXIV}

\section{REINDEER}

RUMOURs floated around that the reindeer would soon be at Nome. In the newspapers there was a notice warning dogowners to keep their dogs shut up, intimating that if they molested the deer the offenders would be instantly shot.

One evening we heard that the herd was outside Nome. Next morning a party of us went out to the abattoir, near which the reindeer were to be corralled. We arrived just in time to see a brown moving mass coming over the hills. This represented 200 head of deer, of whom we were told sixty had stampeded during the night. On they came, a sea of antlers, outlined against the blue sky. As they advanced a little nearer they appeared as big as cows, and were a fine, noble-looking lot of animals, tossing their heads in lordly style, their beautiful soft brown eyes, startled, watching, ready to run at the slightest alarm. We were obliged to get behind a building, as the wind carried our scent to them. Behind the house were stretched brown canvas strips, forming a sort of fence, or corral, within which enclosure the herders were trying to entice the deer. But the leaders appeared to have other views, for just as the herders imagined the animals were going in, all stampeded right up the hillside. Great caution must be used, as otherwise they will run for miles and lose weight. Hurriedly the herders raced to get behind them and stall them off. Now the whole herd turned in a different direction, and stampeded for the creek. We stood and watched operations for hours, until the cold searching wind drove us homeward. The herders worked with the reindeer all day, until about sundown they consented to line up into the corral. Did some instinct warn them that 
death awaited them? At any rate, they did not hasten to their end. Next morning when I went out, there they were, a bunch of beautiful wild creatures, and it seemed a pity to slaughter them. However, people must be fed. In the near future reindeer meat will be known and appreciated over a greater part of the world than hitherto. On the economic side the raising of vast herds of reindeer is extremely profitable, as the deer feeds itself in all seasons without cost, living on the soft reindeer moss. In winter they scrape off the snow with their fore feet and graze contentedly. Deer are very fond of mushrooms: it is their bonne bouche. Nothing about them is unwholesome; they are more cleanliving than most of the animals that we consume. They breed very quickly, and a herd of deer will double its number in three years. The Government first introduced reindeer into Alaska to benefit and feed the Eskimo tribes, and the scheme has been highly successful. A native may acquire a few deer from the Government authorities providing he is sober, industrious, and worthy; then, after five years, he must give back the original number to the Government, keeping the increase for himself; and as they multiply about 33 per cent. per annum, reindeer-raising pays enormously. The climate of the Seward Peninsula is practically the same as that of their native Lapland, and the herds thrive just as well in summer as when three or four feet of snow and ice cover their toothsome moss. In winter their coat grows longer and thicker, giving them the appearance of wearing an extra fur wrap! It is estimated that within a short time there will be over a million reindeer grazing on these vast mosscovered Northlands. Lapland annually sends to market more than 20,000 herds of deer; this would represent 1,660 tons of meat. Taken as an average, a deer will weigh about 120 to 150 pounds a carcass. In a few years something like two million deer will be available for the export market from Alaska, and millions of people could be fed to advantage at a cheaper cost. The Canadian Government propose to encourage and develop reindeer raising, which represents an addition to the supply of fur, hide, and food at little expense. 
This, it is predicted, will become one of the most valuable assets in the development of the Arctic wastes.

The first consignment of deer-185 carcasses-was shipped from Alaska in October, 1911. The meat found a ready sale in the Seattle and San Francisco markets, the retail prices ranging from 25 to 35 cents a pound. A great demand for deer meat, once it has been sampled, has been met with all over the States. The American Government is very keenly interested in advancing the industry.

On the advice of that greatest of Northern explorers, Vilhjalmur Stefansson, the Canadian Government have now gone into the proposition of raising reindeer as well as musk ox for the purpose of home consumption, and for export to England. This would indeed be a blessing, and help to lower the prohibitive price of beef, especially for the poorer classes.

The idea of reindeer being harnessed and made to draw sleds, when you have seen them so frightened, wild, and stampeding, would seem impossible ; yet many reindeer work at sledding in the Arctic lands. When you wish to catch a reindeer you lasso it. They struggle with such violence that occasionally they break their necks. Once caught, you tie your reindeer up; it bucks for a time, and finally becomes more tranquil. Then is the time to steal up and slip over its neck a collar, usually made of two pieces of birch-wood. To the collar is attached a long thick rope, to which you hold on. Then the deer will commence to rear and plunge like a bronco in an effort to get away. After a time, it having become tired, it is more reasonable, and you hitch it to a sled. This period of training is rather a strenuous affair, as frequently the reindeer runs away and the sledge is dashed to pieces. Then begins the work of breaking-in all over again-more lassoing, more training, until the spirit is conquered and the animal rendered docile. Then it will run about 20 miles a day; but if it feels inclined to lie down for a rest it will not move for anyone: its desires must be humoured. The animal is not as good a worker as the dog in this cold country, but, on the other hand, costs nothing 
for its feed, and ultimately the carcass and every part can be utilized. The fur is most beautiful, soft, and rich in colour; brown prevails, although many are mottled with white, and some are white throughout. These furs are chosen by the élite of the Eskimo women for their parkas and mukluks. The sleeping-bags, which all who live in the Arctic must have, are also made of reindeer's fur. Every spring they lose their wonderful antlers. A unique feature in Alaskan winter sports is the Reindeer Fair held annually at Hot Springs, where the reindeers run races. A record was made by a reindeer racer of 10 miles in 27 minutes. In selecting and betting on a reindeer, it is the fore-feet they are judged by, for these are indicative of their speed. The herd produces a very strange sound when on the march, as if their joints were cracking. I am told this peculiarity comes from their knees.

Many of the Eskimos are quite wealthy in a small way; their fortunes exist in the number of reindeer they own. Mary Antesarlook is called the "Reindeer Queen," for she possesses the largest herds. Mollie Dexter is also a deer heiress, and is famous for having the handsomest parkas in all Alaska. By their herds ye shall know them! 


\section{CHAPTER XXV}

\section{ANIMALS OF THE ARCTIC}

ONE of the most interesting of the many curious things in Alaska is the strangeness to English eyes of animal life. Most people, for example, have little idea of the environment and habits of the whale. We all know of whalebone, but how many realize that the bone, or fibre, which is used in corsets and gowns comes actually from the whale's mouth, not from his ribs, or bones, at all? The Balena whale species, from which the whalebone is procured, has an enormous mouth, with a tiny throat in comparison with its huge body, which sometimes measures as much as 80 feet in length. The whale feeds on small fish-sun-fish or jelly-fish for preference. They rush through the water in shoals off the Alaskan coast, and some are white. The mouth is some 8 to 12 feet square. This the whale opens, takes in a great volume of sea-water, which he blows out, or spouts, retaining the small fish to swallow. Attached to both gigantic jaws of this bone-head whale are a series of strainers, sometimes a hundred or two hundred. These long dark strainers are set in layers, each to fit over the other, and form a perfect sieve. As the whale blows out the water, the strainers retain the small fish, which he swallows. These immense strainers have a sort of fringe on the top side, and are most curious to see; and the longer these natural strainers are, the more valuable are they as far as the whalebone is concerned. From these strainers we procure the whalebone so necessary to corsets and other purposes. The whaling industry of Alaska has produced a revenue of more than 100 million dollars. The white, or Beluga whale, a different species, is valuable for its skin, which makes fine leather, and the oil 
from the blubber. Whale steaks are-said to be excellent eating.

Fortunes have been made in the whaling industry. The first Balena whale was discovered by the Americans in the Bering Sea, in 1834. The whale that is said to have swallowed Jonah is of an entirely different species, which frequents the African waters. One would not care to cast any doubt upon the veracity of the Jonah legend, as whales are found that live in the depths which could take one man or even two at a bite!

\section{The Walros.}

Now the walrus, beloved by the Eskimo, feeds in quite a different fashion from the whale. $\mathrm{He}$ is known as the " clam digger." He feeds on clams and all kinds of shellfish, and his great tusks are the finest instruments known for digging. When the Eskimos kill a walrus, they all gather, and immediately rip open the animal's stomach. There they find a clam-bake hot and smoking, and as the Eskimos have no notion of daintiness, they begin a feast at once by taking out the clams and whatever other shell-fish they find, and devouring them.

The walrus hide is as thick as that of a rhinoceros, only that animal has what might be termed three skins, each in layers; the fat layer, or blubber, remains in the middle. All around the shores of Alaska are many hundreds of walrus, living mostly on the ice floes, where they herd together. A walrus will average 10 to 12 feet in length, and will weigh about 2,000 to 3,000 pounds. The blubber will weigh at least 500 pounds, and the resultant oil is very valuable. Their hides are covered with a rough reddish-brown hair, and heavily wrinkled; they make the toughest leather. Their eyes are tiny for so large an animal, and their ivory tusks are made into all kinds of curios and articles of utility.

The fur industry of Alaska, or the Seward Peninsula, represents over 100 million dollars, and now that so many furs of all kinds from Siberia are exported through the port of Nome, the amount will be largely increased. Every week 
small boats come over from the Diomede Islands and Siberia full of furs. I have myself watched 1,200 beautiful white foxes heaped up on the floor of a trading house, being sorted and ruthlessly pushed into sacks to be sent "outside" for redressing. In another pile were 600 red foxes awaiting export. A trader in a curio-shop I visited had a bag containing countless thousands of dollars' worth of finest Russian sables, the dark variety which are in such demand, and the cost of which is prohibitive except to millionaires. They were certainly lovely. The Alaska seal industry is controlled by the U.S. Government, and only a certain number of skins are placed on the market each year. These seals, from which the recognized sealskin coats are made, come from the Pribilof Islands, and were in danger of being exterminated; but as they are now protected, in time to come the markets of the world will become replenished, and lovely woman again be able to deck herself in sealskin, genuine and unsophisticated. That beautiful fur, the sea-otter, which the Russians so ruthlessly slew, may make its reappearance in limited quantities-a joy to the eye and the wearer. This vast Alaska is rich in furs, a treasure-house of its kind. 


\section{CHAPTER XXVI}

\section{FINALE}

A DAY came when, out in the roadstead off Nome, a steamer rocked, the s.s. Senator of the Admiral Line. Only two steamers cater to the Nome service, sailing from Seattle. The other is s.s. Victoria, of the Alaska Steamship Co. I was to leave on the Senator, and although it was early in September, even then the Arctic winds chilled one at night. The clans of Lindeberg, Heckman, Frawley, Cochran, Coles, and various others, with the characteristic good-heartedness of the Northerners, came down to the wharf to bid me farewell. The crowded tender pushed off, and the distance lengthened between us. Then a grey veil of mist descended, deftly obscuring Nome, and in a few moments the iron sides of the Senator were confronted. The steamers are old; but one does not expect the cabins de luxe of the Olympic, or of other ocean greyhounds. I came on deck. The veil of grey mist had lifted, as if again to show me Nome for the last time. I had roamed its streets, received lavish hospitality from rich and from poor-I even knew most of its dogs by name; had become familiar with its Eskimos, customs, peoples, and legends; had panned for gold in its creeks, helped drive the reindeer in corral, and had watched over the smelting of its virgin gold. Nome was an open book to me; I had read that book, and liked it. Now the ship cuts the waves towards Seattle, and probably my steps will never more turn to Nome. As I look over the taffrail into the sea, the thought comes to me that in a few weeks this sea will become lumpy with ice, increasing each moment; then the Arctic key will be turned, and Nome prisoned fast until next June. The wireless will flash the news over thousands of miles of snow and ice, and the faithful dog-team will bring 
the mail twice a week to this farthest-away big town of the Seward Peninsula.

In reviewing this great Northland, rich in its metals, its furs, and fisheries, still hiding its treasure for future generations, waiting for the millions with indomitable spirit to conquer it and grasp its wealth, one feels sure that Alaska has a great and brilliant future, as has the mighty Yukon and the Northern Provinces of Canada. But people and the transport are badly needed. Then, towns will spring up like the wildflowers, homes will be built, and the land will throb with vital, pulsating life, not as to-day, when you can cover hundreds of miles without meeting a human being. Let the Governments of Canada and the United States help these Northern children. Their spirit and cheerful optimism will conquer; all they ask is adequate means of transport. Give Yukon and Alaska a chance, and they will no longer remain the Cinderellas of the Northern latitudes, but will take their rightful places in the great bustling world. After eight days of pleasant life on board the Senator-the passengers were mostly men of the school of Bret Harte-Seattle appeared out of the darkness. We landed at about 10.30 p.m. at this " Seaport of Success," as it is locally named. It claims to be the best-lighted city in America. The countless illuminations were dazzling, and especially noticeable was the enormously high Smith building, with its forty-two stories. Imagine a million window-panes blazing like luminous eyes ! The city is built upon a succession of steep hills running down to the docks. The next day I had the good fortune to meet Mayor Ole Hanson, Seattle's most popular and fearless chief magistrate, whose steadfast courage in fighting and suppressing the Bolshevists has endeared him to the hearts of the people, and gained for him the admiration of every country.

Seattle is the most up-to-date and prosperous of cities. It has an area of over 60 square miles, 178 miles of paved streets, 121 miles of planked thoroughfares, 28 parks, and 31 miles of scenic boulevards. Its residential quarters are

- famed for beauty as well as spaciousness. From Seattle to 
Victoria I journeyed by luxuriously comfortable steamersVictoria, the city that has the reputation of being more English than the English themselves. The Empress Hotel, belonging to the Canadian Pacific Railway, appeared to me the acme of good taste and luxury, with its ivy-mantled walls, and window-boxes blossoming loyalty in their red, white, and blue flowers. The Government building is the equal of any of the finest structures to be found in any part of the globe. Victoria, with its beautiful drives and no less beautiful homes, leaves a lasting and pleasant memory.

Then Vancouver, picturesquely situated in a mountainous environment, very clean and modern. One of its attractions is the splendid, well-managed Vancouver Hotel. From its pretty roof-garden a superb view is obtained. Now one comes into the efficient hands of the Canadian Pacific Railway, and as long as one remains with them one has solid comfort all the way-in their palatial hotels, in their trains, which are equipped with drawing-room, observation, and dining cars, excellent meals and service. In fact, all your wants are immediately anticipated, and every desire catered for. It is September, when Nature is lavish with her paintbox, and maple leaves are resplendent with every shade. In order that you may traverse the continent and skip none of its interests, the Canadian Pacific issue their tickets so that you can travel all through the day and disembark to sleep. Their hotels are scattered along the route, and you are able to enjoy to the full the magnificent scenery of the Rocky Mountains by daylight. I left Vancouver early in the morning, and exulted in the wonderful mountain scenes-the Fraser River, its falls and canyon were a sheer delight. I arrived at Sicamous in the evening. After a refreshing night's rest, breathing the scented pine-laden air, and partaking of a real English breakfast at the pretty inn-like hotel of the C.P.R., the train comes along, picks you up, and you have another glorious day before you. On every train there are open cars, and it is just like a motor trip through the Rockies. Oil only is burned on this part of the trip, consequently there is neither dust nor cinders. Every moment 


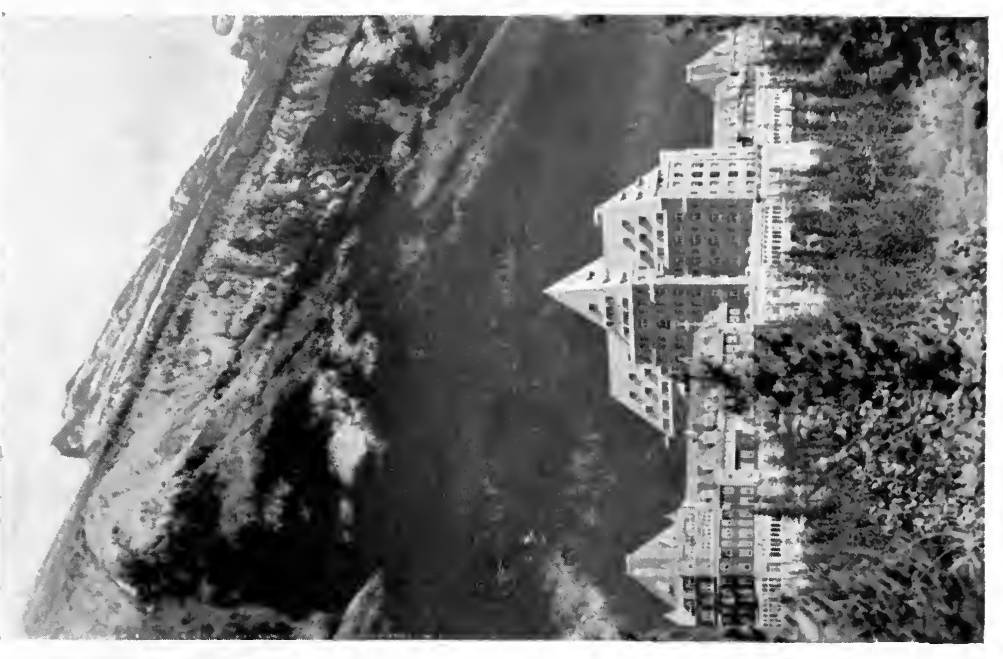

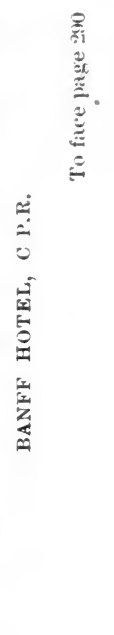

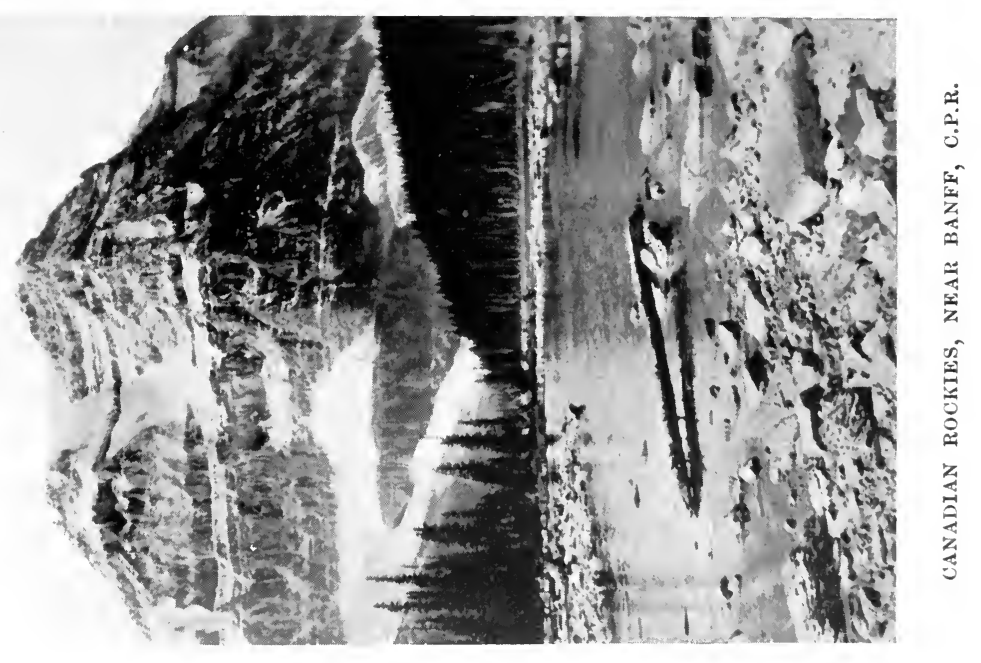



you are climbing higher, until, at Glacier, 3,780 feet is reached; snow-clad Mount Sir Donald towers into the sky. The Mount Stephen Hotel at Field, 4,072 feet in altitude, looks most inviting. On we go, until Lake Louise, 5,044 feet, is approached. Here I stay several days. Lake Louise is the gem, not only of the Rockies, but of the world, a jade lake set in pearls. The snow summits of countless mountains form its wreath. These lofty peaks are ever regarding their beauties in the mirror of Lake Louise. This sublime lake baffles description; no mere word painting could afford it justice. Here the C.P.R. have a splendid hostelry, the Château Louise. The next beautiful spot en route is Banff, whose huge Scotch baronial castle is named Banff Hot Springs Hotel, and is another triumph of artistic conception. Calgary comes next, a comparatively new city, surrounded by the great golden prairies. Anyone not knowing Calgary would be astonished at this growing, progressive place, with its sky-scrapers, very good shops, and thoroughly up-to-dato Hotel Palliser. Winnipeg, Queen of the Prairies, a huge city, with a large foreign population, many Russians, Galicians, and Poles, and a multitude of fine banks, shops, and hotels. From Winnipeg to Montreal, from Montreal to England.

Peace! What a difference it all makes! When I came to America by army transport, at 11 a.m. every day boatdrill was held, and woe betide anyone who appeared on deck without their life-preserver! No lights were shown as we speeded across the ocean, every moment fraught with peril. Now the seas are cleared one can travel in freedom and breathe God's good air without a care for lurking dangers. Let us see that we keep the rainbow of Hope in our hearts. ... .

For those who love travel, for those who delight in the great glories of Nature, there will be no disappointment in this vast territory of Yukon and Alaska. There, too, you will grasp the friendly hands of the Northerners, the kindesthearted and most hospitable people on God's good earth. 


\section{AFTERTHOUGHTS}

Was this journey of 20,000 miles really worth while? The hardships, the inconveniences, the rebuffs, were they worth it all?

Of a surety! This long, long jaunt to the Arctic snows has brought me face to face with a race of men and women whom one is proud to own as kin-the pioneers, the men who blaze the trail, the men who, God willing, will point the way to that coming race of pioneers who will set out to conquer these ice-locked vastnesses.

It has brought me, jaded dweller within restless towns, to

The forests where silence has lease,

and it has revealed to me in a score of unmistakable ways that this mighty Northland will yet ring out its clarion call to the young, the brave, the venturesome, and that its rebirth may come about sooner than you or I would dreamaye, within the next decade.

For men have but scratched the surface of this frozen zone, just as the unchanging Arab has merely scratched the soil of his homeland. What are the treasures of Ind as compared with the treasures of this limitless land of sunshine and snow?

Oh, a wondrous land will be the Alaska of to-morrow, a very Pandora's Box in the story of the future!

Alaska hungers for men, real men; her virgin acres cry out for them. These, her sons, she will clasp to her ample bosom; to these, and to these alone, will she reveal her treasures and her mysteries. 



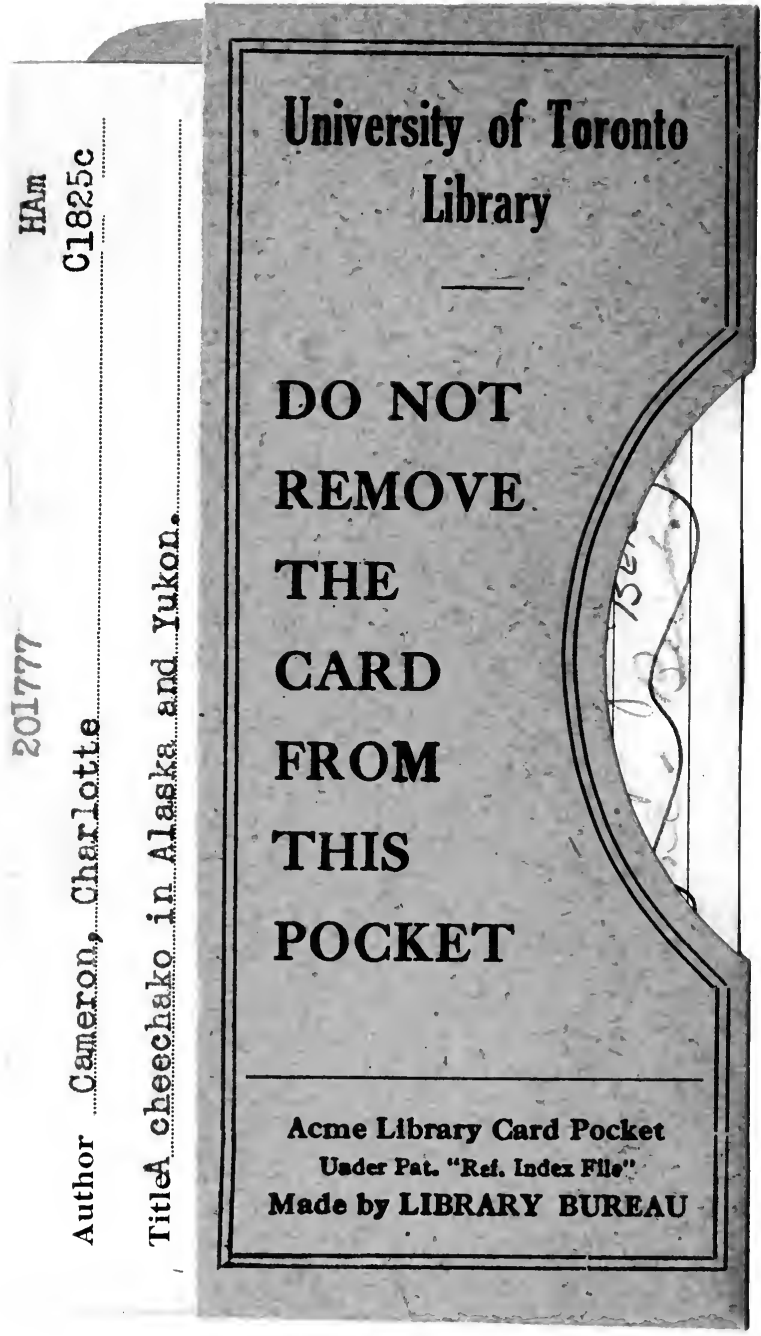


